DEPARTMENT OF THE INTERIOR

UNITED STATES GEOLOGICAL SURVEY

GEORGE OTIS SMITH, DIRECTOR

BuLletiN 492

\title{
THE GABBROS AND ASSOCIATED ROCKS AT PRESTON, CONNECTICUT
}

BY

G. F. LOUGHLIN

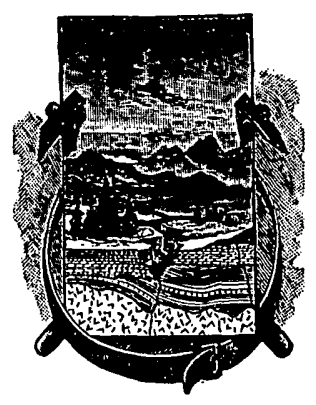

WASHINGTON

GOVERNMENT PRINTING OFFICE 1912 



\section{CONTENTS.}

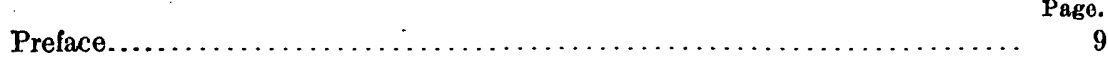

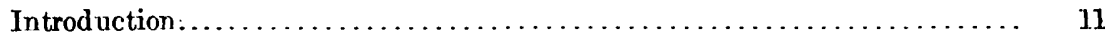

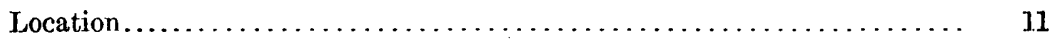

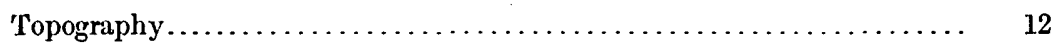

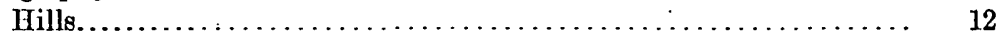

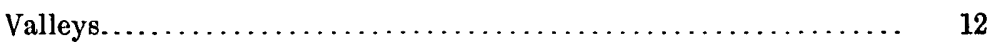

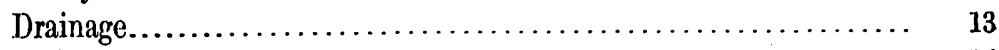

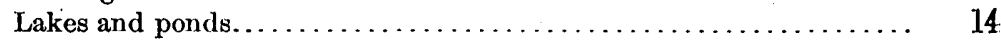

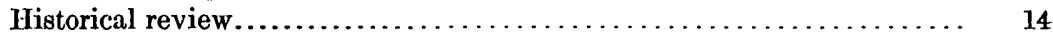

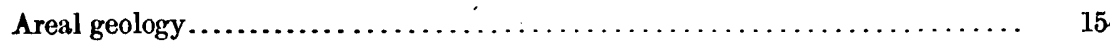

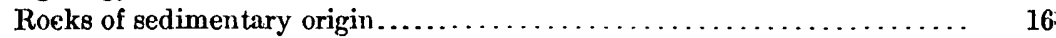

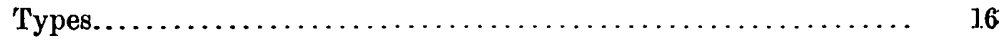

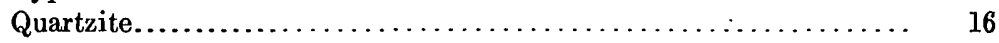

Quartz-biotite schist. . . . . . . 17

Hornblende schist. . . . . . . . 18

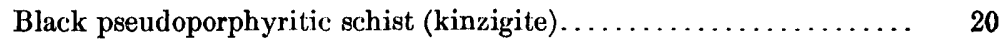

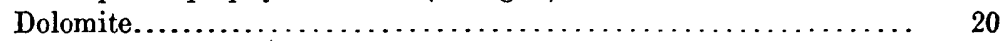

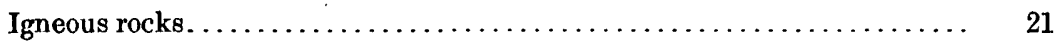

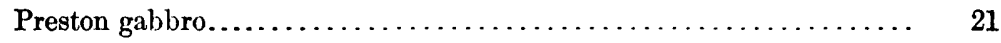

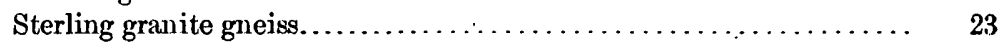

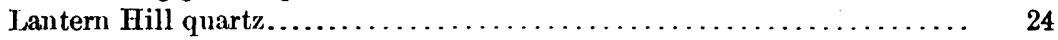

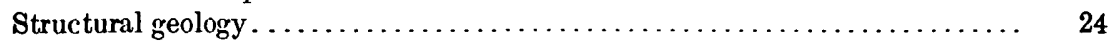

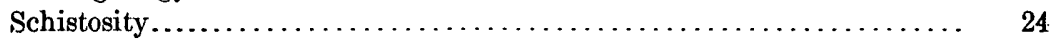

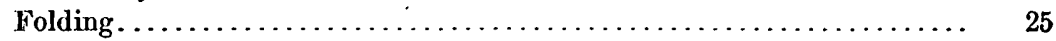

Undulations. . . . . . . . . . . . 25

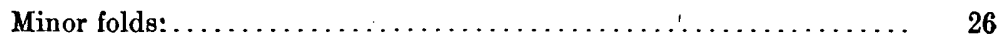

Major folds. . . . . . . . . . . . . . . 28

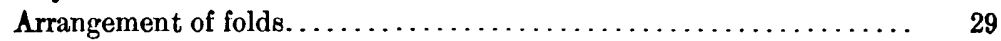

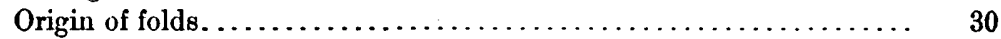

Effect of the gabbro intrusion..................... 30

Effect of the granite intrusion..................... 32

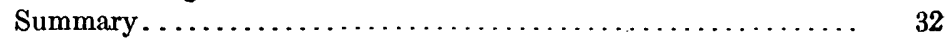

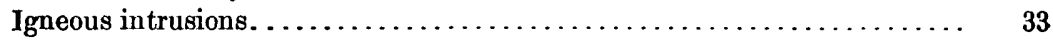

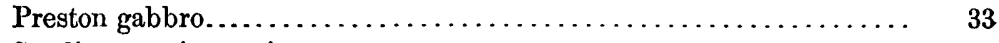

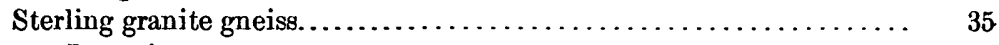

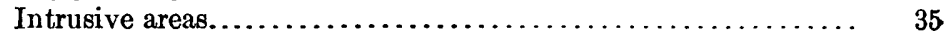

Porphyritic granite gneiss areas. ................ 35

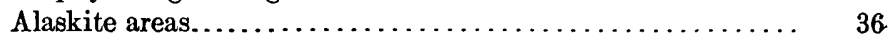

Normal granite gneiss areas...................... 36.

Minor sheets and dikes........................ 37

Structural interrelations of the granite intrusions......... 37

Method of intrusion.............................. 38 
Structural geology-Continued. Page.

Metamorphic deformation................................ 38

Regional metamorphism of the Preston gabbro................. 38

Contract metamorphism due to the Preston gabbro.............. $\quad 39$

Regional metamorphism of the Sterling granite gneiss............ 43

Contact metamorphism due to the Sterling granite gneiss......... 43

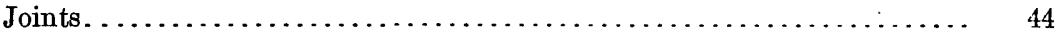

Distribution and directions............................. 44

Origin of joints. . . . . . . . . . . .

Relation of joints to stream courses....................... 48

Principal valleys................................... 48

Major tributary valleys................................... 49

Minor tributary valleys............................... $\quad 50$

Conclusions....................................... 50

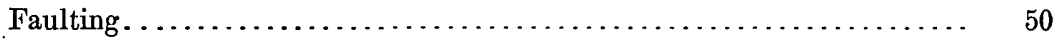

Character and distribution................................ 50

Ashwillet intrusion fault................................... 51

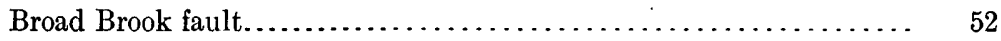

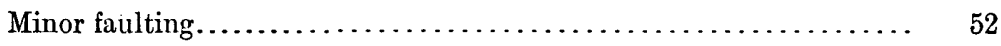

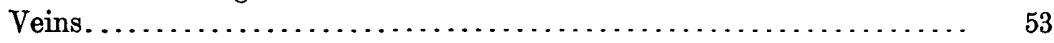

Quartz veins.......................................... 53

Chlorite and asbestos veins in gabbro....................... 53

Special erosional features.................................. 54

Pitted and warty surface of gabbro......................... 54

Dissolution holes....................................... 54

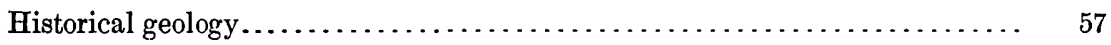

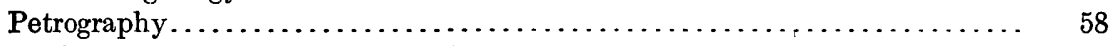

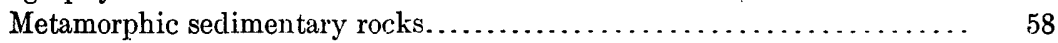

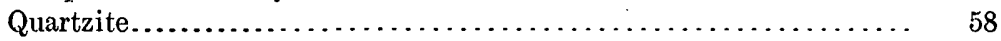

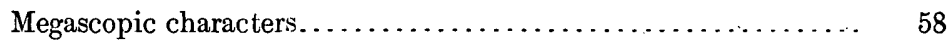

Microscopic characters........................... 58

Variations and similar rock from other horizons............ 59

Quartz-biotite schist.............................. 59

Megascopic characters............................ $\quad 59$

Microscopic characters............................. $\quad 59$

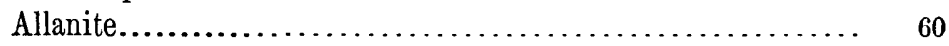

Variations.......................................... $\quad 60$

Epidote gneiss....................................... 61

Hornblende schist. . . . . . . . . . . . . . . . . 62

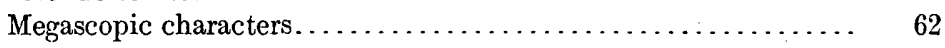

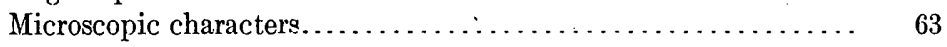

Variations........................................ 63

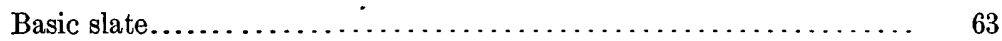

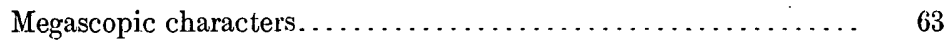

Microscopic characters.............................. 64

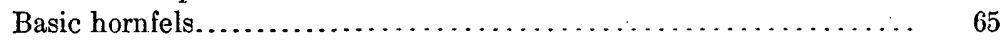

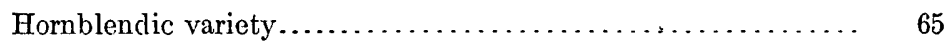

Megascopic characters........................... $\quad 65$

Microscopic characters......................... 65

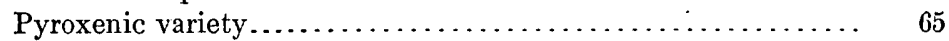

Megascopic characters........................... $\quad 65$

Microscopic characters........................... $\quad 65$

Origin of the hornblende schist...................... $\quad 66$ 
Petrography-Continued.

Metamorphic sedimentary rocks-Continued.

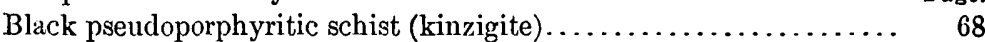

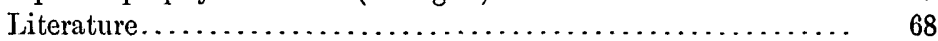

Megascopic characters............................. 68

Microscopic characters............................... 71

Chemical composition............................... 72

Variations..................................... 73

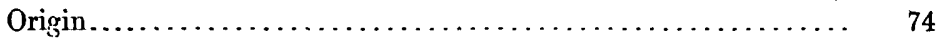

Dolomite......................................... $\quad 76$

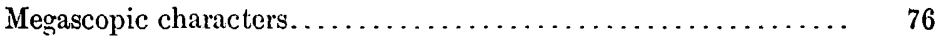

Microscopic characters............................. $\quad 77$

Variation........................................... 78

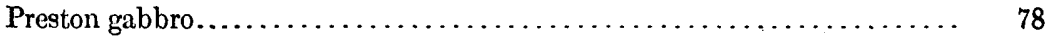

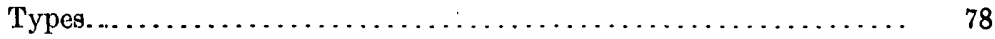

Porphyritic gabbro.................................... 79

Normal phase................................. $\quad 79$

Megascopic characters........................ $\quad 79$

Microscopic characters............................. 80

Mineral structure....................... $\quad 80$

Diallage................................... $\quad 80$

Secondary brown hornblende. . . . . . . . . . . . $\quad 80$

Biotite............................... $\quad 84$

Labradorite.............................. 84

Ilmenite.............................. 87

Chlorite-magnetite aggregates. . . . . . . . . . . . . 88

Pyrite.................................. 88

Quartz-calcite veinlets....................... 93

Mechanical and chemical metamorphism .............. 93

Chemical composition........................... $\quad 94$

Classification................................... 94

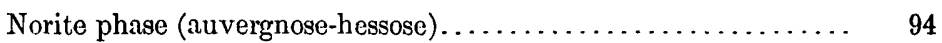

Megascopic characters........................... $\quad 95$

Microscopic characters.......................... 95

Mineral structure........................... 95

Labradorite............................... 95

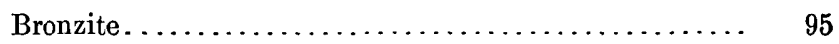

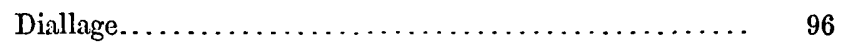

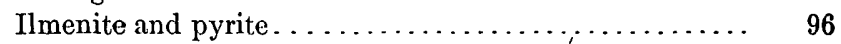

Alteration products........................ $\quad 96$

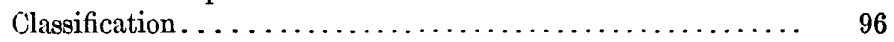

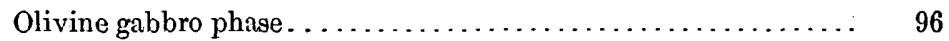

Megascopic characters............................ 96

Microscopic characters......................... $\quad 96$

Mineral structure......................... 96

Bytownite........................... 97

Olivine................................. 97

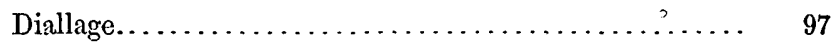

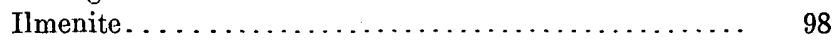

Chemical composition ........................... 98

Pyroxenite phase................................. $\quad 98$

Megascopic characters......................... $\quad 98$

Microscopic characters.......................... 98 
Petrography-Continued.

Preston gabbro-Continued.

Porphyritic gabbro-Continued.

Pyroxenite phase-Continued.

Microscopic characters-Continued. Page.

Mineral structure........................ 98

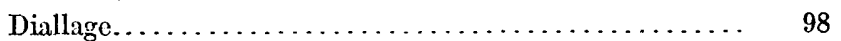

Ilmenite. . . . . . . . .

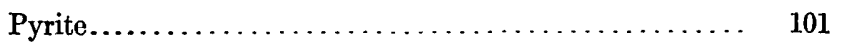

Labradorite............................... 101

Brown hornblende. . . . . . . . . . . . . . . . . 101

Chemical compositio $1 \ldots \ldots \ldots \ldots \ldots \ldots \ldots \ldots \ldots \ldots \ldots . . \ldots 1$

Basic pegmatite phase . . . . . . . . . . . . . . . . . . . 101

Local diabase dikes............................. 101

Megascopic characters......................... 101

Microscopic characters........................... 101

Quartz-hornblende gabbro (auvergnose).................. 102

Normal phase.................................... 102

Megascopic characters........................ 102

Microscopic characters........................ 102

Mineral structure....................... 102

Labradorite................................ 105

Augite.................................. 105

Hornblende........................... 105

Quartz................................ 106

Ilmenite and pyrite..................... 107

Biotite................................. 107

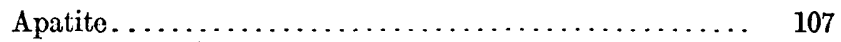

Classification............................. 108

Relation of quartz-hornblende gabbro to porphyritic gabbro. 108

Diallage gabbro segregations........................ 108

Quartz anorthosite and quartz hornblendite............. 108

Basic pegmatite and aplite ....................... 109

Oligoclase granite (alsbachose) . . . . . . . . . . . . . . . 109

Megascopic characters........................ 109

Microscopic characters........................ 109

Mineral structure . . . . . . . . . . . . . . . . . 109

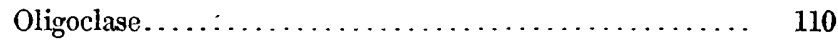

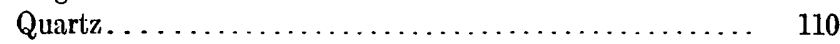

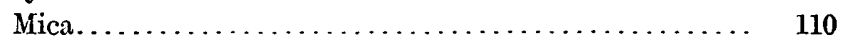

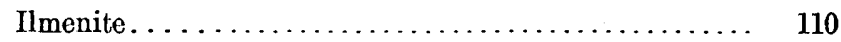

Other minerals..................................... 110

Classification................................ 110

Relation of oligoclase granite to quartz-hornblende gabbro... 111

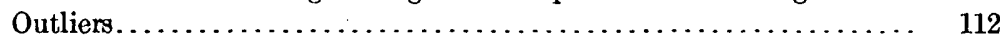

Gabbro....................................... 112

Amphibolite sheets. ........................... 112

Megascopic characters........................ 112

Microscopic characters........................ 112

Mineral structure. . . . . . . . . . . . . . . . . . . . 112

Hornblende. . . . . . . . . . . . . . . . . . . . 112

Labradorite................................ 113

Other minerals............................. 113

Relations of amphibolite sheets to gabbro types......... 113

Differentiation of members of the Preston gabbro.............. 114 
Petrography-Continued. Page.

Sterling granite gneiss. . . . . . . . . . . . . . . 119

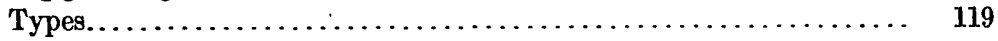

Porphyritic granite (lassenose-toscanose) . . . . . . . . . . . 120

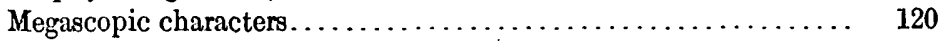

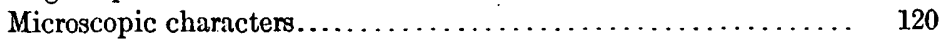

Chemical composition. . . . . . . . . . . . . . . . . 122

Quantitative classification . . . . . . . . . . . . . . . . . 122

Alaskite (alaskose-liparose) . . . . . . . . . . . . . . . . . . . 123

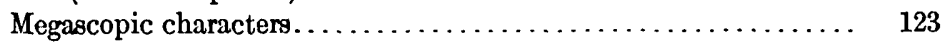

Microscopic characters........................... 124

Chemical composition. . . . . . . . . . . . . . . . . 125

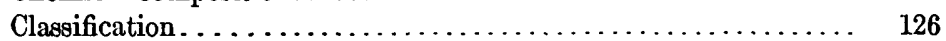

Normal or even-grained granite . . . . . . . . . . . . . . . . 126

Hornblendic granite............................. 126

Minor intrusive sheets and dikes. . . . . . . . . . . 126

Megascopic characters........................ 127

Microscopic characters......................... 127

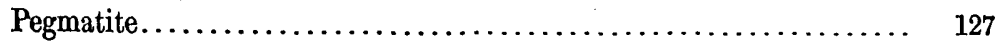

Relation of microstructure of the Sterling granite gneiss to regional

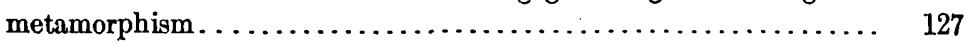

Relation of intrusion and deformation . . . . . . . . . . . 127

Evidence in alaskite . ......................... 129

Evidence in porphyritic granite . . . . . . . . . . 130

Evidence in normal Sterling granite gneiss. . . . . . . . . 131

Summary ................................... 131

Age and conditions of the granite gneiss intrusion . . . . . . . . 131

Probable extent of the granite gneiss batholith . . . . . . . . . . 133

Relation of Sterling granite gneiss to Westerly granite......... 135

Geology of Lantern Hill $\ldots \ldots \ldots \ldots \ldots \ldots \ldots \ldots \ldots \ldots \ldots \ldots \ldots \ldots \ldots \ldots \ldots$

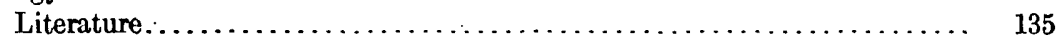

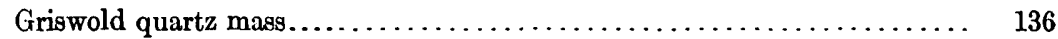

Lantern Hill quartz mass. . . . . . . . . . . . . . . . . . . 137

Occurrence and microscopic characters................. 137

Microscopic characters............................. 139

Replacement................................ 143

Preservation of the quartz-biotite schist inclusion . . . . . . . . . 144

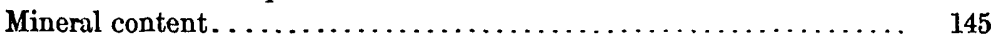

Other quartz masses in the region $\ldots \ldots \ldots \ldots \ldots \ldots \ldots \ldots \ldots \ldots \ldots$

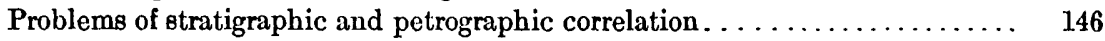

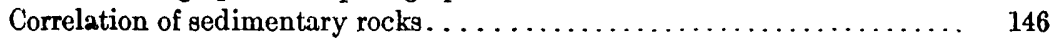

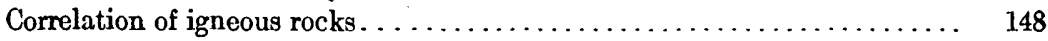

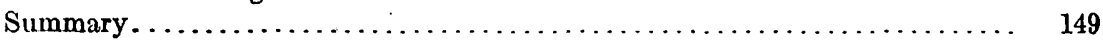

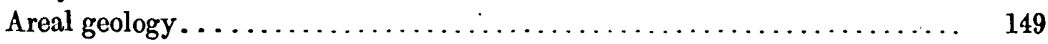

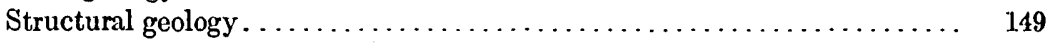

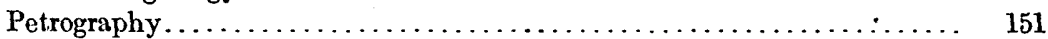

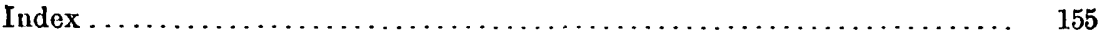




\section{ILLUSTRATIONS.}

Plate I. Map of parts of Stonington and Moosup quadrangles, New London County, Conn . . . . ............................ . pocket.

II. Geologic map of parts of Stonington and Moosup quadrangles, New London County, Conn ........................... In pocket.

III. Map showing location of outcrops studied and the provisional nature

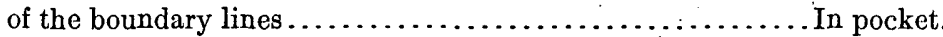

IV. Generalized strike and dip of rocks in area covered by geologic

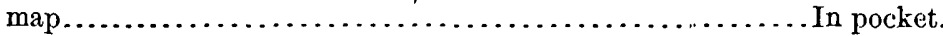

V. $A$, Photomicrograph of epidote gneiss; $B$, Photomicrograph of part of a diallage phenocryst inclosing labradorite and ilmenite........

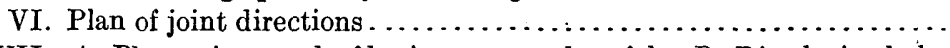

VII. $A$, Photomicrograph of basic pyroxene hornfels; $B$, Dissolution holes in porphyritic gabbro

VIII. $A$, Photomicrograph of pseudoporphyritic kinzigite; $B$, Specimen of pseudoporphyritic kinzigite . ........................

IX. $A$, Photomicrograph of partly saussuritized gabbro; $B$, Photomicrograph of diallage crystal in gabbro.........................

X. $A$, Photomicrograph of moderately mashed gabbro; $B$, Photomicrograph of chlorite-magnetite aggregate . ....................

XI. $A$, Photomicrograph of highly mashed gabbro; $B$, Photomicrograph of extremely mashed gabbro.............................

XII. $A$, Photomicrograph of pyroxenite; $B$, Photomicrograph of olivine

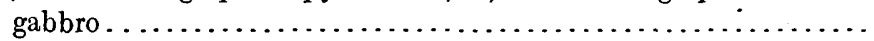

XIII. $A$, Photomicrograph of quartz-hornblende gabbro; $B$, Photomicrograph of hornblende crystals in quartz-hornblende gabbro........

XIV. $A$, Photomicrograph of partly replaced alaskite; $B$, Photomicrograph of alaskite completely replaced by quartz.................

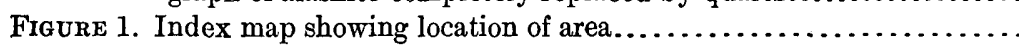

2. Overturned minor undulations or crumplings in schist............

3. Minor undulations, mostly normal or oblique to general strike and dip.

4. Folding inferred from relations of pegmatite and amphibolite sheets.

5. Crumpled schist within fold of rigid lime-silicate rock...........

6. Small fan-shaped fold in schist near North Stonington limekiln....

7. Restored section showing close folding of a dolomite bed 10 feet thick at the North Stonington limekiln....................

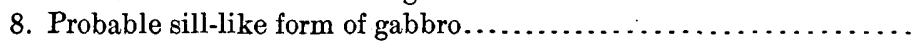

9. Simplified plan of gabbro mass, showing results of eastward com-

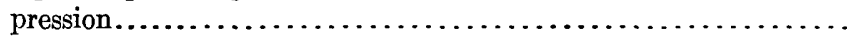

10. Effect of transmitted force on surrounding schists................

11. Apparentand more probable thickness of porphyritic granite sheet in Griswold.

12. Granite dike crossing syncline in hornblendic kinzigite and sending stringers along foliation.

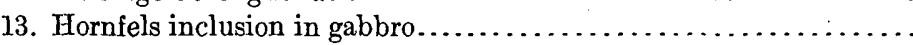

14. Curve showing distribution and relative importance of joint systems.

15. Black dustlike inclusions in feldspar of gabbro. . . . . . . . . . . . .

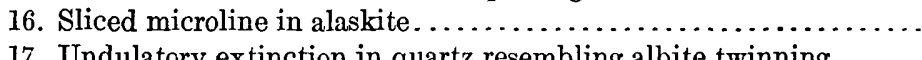

17. Undulatory extinction in quartz resembling albite twinning....... 122

18. Granulation and weld fractures (?) of a quartz grain in alaskite.... 124 


\section{PREFACE.}

The studies and results embodied in the following pages were presented as a thesis in part fulfillment of the requirements of the degree of $\mathrm{Ph}$. D. at Yale University, New Haven, Conn., in June, 1906; but several causes, especially pressure of other duties, delayed its revision for publication until 1908. The writer first visited the field of study in the summer of 1904, as field assistant under Prof. H. E. Gregory in making a preliminary geological map of Connecticut for the State Geological and Natural History Survey. Ten weeks of the summer of 1905 were spent in detailed study of the region. The working up of notes, microscope study, and chemical analyses occupied the greater part of the following winter. The study, during the summers of 1907 and 1908, of a large number of thin sections, received too late to be embodied in the thesis, two brief visits to the field, and more mature deliberation on certain doubtful points, have warranted an extension and revision of some of the conclusions originally presented.

The work was carried on under the supervision of Profs. H. E. Gregory, L. V. Pirsson, and Joseph Barrell. The thin sections were made by Mr. F. Ohms, and four of the chemical analyses were made by Dr. George Steiger in the laboratory of the United States Geological Survey. Two analyses were kindly made by Mr. W. A. Drushel, of Kent Laboratory of Yale University. The writer here expresses his indebtedness also to Dr. F. P. Gulliver for the use of an unpublished description of a part of the field and for a map which aided greatly in locating several limestone outcrops, and to Dr. Albert Johannsen, of the United States Geological Survey, for his very helpful criticism of the manuscript. 



\section{THE GABBROS AND ASSOCIATED ROCKS A'T PRESTON, CONNECTICUT.}

By G. F. Loughrin.

\section{INTRODUCTION.}

LOCATION.

The region described in this paper is a small quadrangular area in the eastern crystalline rocks of Connecticut, covering about 102 square miles. (See fig. 1 and Pl. I.) It is bounded by parallels

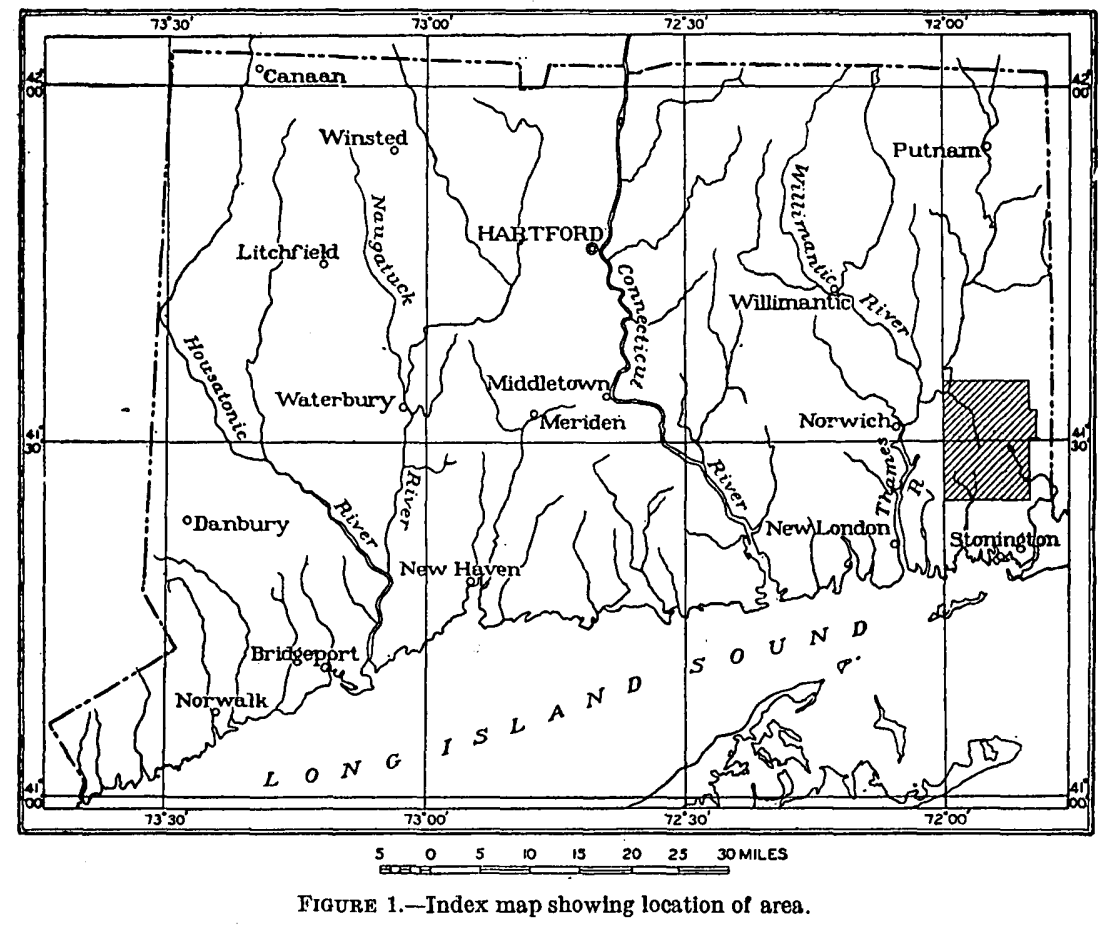

$41^{\circ} 25^{\prime}$ and $41^{\circ} 35^{\prime}$ and meridians $71^{\circ} 50^{\prime}$ and $72^{\circ}$. Only its extreme northwest corner is traversed by a railroad, but the whole of it may be reached by trolley or carriage from Norwich and other towns along the New York, New Haven \& Hartford Railroad. 


\section{TOPOGRAPHY.}

The area described lies within the dissected Crataceous peneplain which extends throughout southern New England. It consists mostly of moderately sloping glaciated hills, only a few of which rise above the 500-foot contour. Valleys or plains of considerable size comprise only a minor fraction of the area.

Hills.-The highest hill, Bay Mountain, in the north-central part of the area, rises more than 560 feet above sea level. Prentice Mountain, second in height, passes the 540-foot contour. Both these hills consist of gabbro, capped by patches of a basic hornfels. Most striking, however, is Lantern Hill, in the southwest quarter, which, rising 520 feet above sea level, forms a narrow ridge of almost solid quartz, with vertical walls flanked by talus. It rises 400 feet above the narrow valleys at its base, and more than 100 feet above the nearest hills. The remaining hills, which rise to a height of 500 feet or more, consist of gabbro, gneissoid granite, or quartzite. Nearly all the hills have smooth, till-covered northern and western slopes, and many of them would be not unlike large drumlins were not their eastern and southern slopes generally rocky and in many places precipitous. Their forms are due chiefly to rock structure, and their smooth surfaces and even outlines to glaciation. Those in the north-central part of the area consist of massive gabbro which possesses little or no foliation, and are nearly circular in outline; those in the remainder of the area consist of monoclinal masses of highly foliated metamorphic sedimentary rocks, interspersed with sheets of gneissoid granite, and are elongate or elliptical, agreeing in length and slope with the strike and dip of the foliation. The gneissoid granite sheets are more resistant to erosion than the metamorphic sedimentary rocks, and the former, where of sufficient size or abundance, determine the positions of the hills. (See Pl. II.)

Valleys.-The valleys may be classed as principal, major tributaries, and minor tributaries. (See p. 48.)

The principal valleys are six in number, those of Quinebaug, Pachaug, Shunock, and Mystic rivers, Broad Brook, and the area known as Preston Plains, extending from the town of Preston southward into Ledyard. They are the basins of former glacial lakes and consist of level deposits of stratified drift, generally bordered by terraces and kames. They contain the largest ponds and swamps of the region.

The major tributary valleys include those of the larger tributary streams. They may, especially in their lower courses, be characterized by stratified drift, but are for the most part narrow. and $V$ shaped. Many of the larger ones are deep, and some in North Stonington have walls which rise steeply for more than 100 feet. 
The minor tributary valleys include all those remaining. They occur alike in level and hilly country, and deserve mention only because of the relation between those cut in hillsides and the direction of joints. (See p. 50.)

Drainage.-The drainage, as clearly shown on the topographic map (Pl. I), is typical of New England, and only a few special features deserve notice. The first of these is the number of low divides. The principal valleys, as well as several major tributaries, are connected by narrow strips of low land, and the sources of the streams draining them are in several places separated by divides too low to be shown by contours on the topographic map. Though the present form of a few of these low divides may be due to glacial deposition, they indicate, as a rule, slight elevations in the bedrock surface and suggest that stream capture was gradually taking place prior to the glacial epoch.

Another marked feature of the drainage is the sudden westward bend of Quinebaug River, in the northwest corner of the area, into a narrow valley, walled by steep ledges and floored by a succession of rapids. The youthful character of this westward course leads one to suspect that the river was here diverted from its preglacial course by glacial deposits; but attempts to prove the presence of such glacial deposits were unsuccessful. Although the Quinebaug above the bend has not yet cut through the glacial drift to bedrock, its continuation southward at the bend, along either the valley of Broad Brook or that of Preston Plains, is prevented by rock outcrops rising 100 feet above its narrow flood plain. If, therefore, the Quinebaug within the area is in its preglacial course at all, some other explanation than diversion at this point is necessary.

The position of the valley of Preston Plains, in direct line with the southerly course of the Quinebaug, and its great width relative to the small stream now occupying it, suggests that the Quinebaug, in early Tertiary time, flowed directly southward over Preston Plains, through the narrow but deep gorge at the west base of Lantern Hill, and down the valley of the Mystic to the sea. The rock structure is favorable to such a course. It is possible that the sudden westward bend is due to preglacial stream capture, but the evidence to prove such an hypothesis lies beyond the limits of the area here considered. If this hypothesis is correct, the presence of the abandoned valley in the dissected peneplain means that capture must have followed the post-Cretaceous uplift.

Broad Brook is also conspicuous. Rising in the glacial gravels of Ashwillet, it flows northwestward across the main mass of gabbro, the intrusion of which, as will be shown later, produced a domal uplift. Passing from the gabbro it follows a probable fault for a mile or more across the strike of the schists and finally reaches the 
Quinebaug at the latter's westward bend. As Broad Brook emptied into the trunk stream and also followed along a probable zone of weakness, it had the advantage over the other streams and succeeded in cutting back its channel into the gabbro area. As it was then the most favorably located of uthe streams draining this area, it eventually became the principal stream. Owing to the structure of the foliated rocks around the gabbro mass, a certain amount of radial and annular drainage therefrom still persists, in spite of the fact that peneplanation has destroyed the effects of the domal uplift. Broad Brook, however, following the fault zone, is independent of the general rock structure.

Lakes and ponds.-The lakes and ponds of the area have nearly all been enlarged by artificial damming, and some, notably Pachaug Pond, the largest in the region, are wholly artificial. Most of the natural lakes and ponds are the result of glacial damming and are the remnants of glacial lakes, and the artificial ponds and swamps lie in the basins of drained glacial lakes.

The clearest example of impeded drainage due to glacial deposition is in the southwest quarter of the area between Cedar Swamp and Lantern Hill. Kame deposits destroyed the original outlet, and caused the development of a lake, in the area now occupied by Cedar Swamp and Avery Pond, with its margin at about the present 80-foot contour. Amos Lake, north of Avery Pond, is the remnant of another smaller and probably connected lake. Another good example of glacial damming is along the southeast boundary of the area, where a kame deposit diverted the former southerly drainage to the east through Spalding Pond and caused the formation of a swamp, also called Cedar Swamp.

As previously stated, all the principal valleys are evidently the basins of extinct glacial lakes. The lake of highest elevation was in west Voluntown, and its marginal deposits now lie at the 360-foot level. Other lakes were formed in south Voluntown north of Pendleton Hill; at Ashwillet, of which Wyassup Lake, the margin of which is at the present 320 -foot level, is a probable remnant; in the basin of the present Pachaug Pond, with marginal deposits at the 220-foot level; in the upper valley of Broad Brook, with marginal deposits near the 220-foot level; and in the lower valleys of Broad Brook and of the Quinebaug, with marginal deposits at the 180-foot level.

\section{HISTORICAL REVIEW.}

No record of detailed work previous to the present investigation has been published in reference to the area or its vicinity for nearly three-quarters of a century. In 1834, Lieut. William W. Mather ${ }^{1}$

1 Mather, W. M., Sketch of the geology and mineralogy of New London and Windham counties in Connecticut, 1834. 
published a "Sketch of the geology and mineralogy of New London and Windham counties in Connecticut," but this was merely a brief description of the composition, extent, structure, and economic value of the various formations. No attempt was made to solve any of the geologic problems of the region.

In 1837 Prof. C. U. Shepard ${ }^{1}$ published for the Connecticut Geological Survey a report on the mineral resources of the State, which shows that eastern Connecticut, then as now, was of no great economic importance geologically. The one place in the area which he mentioned is the old limekiln in North Stonington, where dolomite was quarried. The kiln was not in use at the time of Shepard's visit, and according to Mather ${ }^{2}$ its production was on the decline prior to 1834. The kiln and pits to-day are overgrown and partly filled by trees and bushes which have grown, died, and rotted since the place was last worked. The quarry was never steadily worked, and the lime, according to Mather, was not of the highest grade.

In 1842 Prof. J. G. Percival ${ }^{3}$ published a survey report on the geology of Connecticut. His descriptions, as well as his map, show the thoroughness of his work, and although little was known of metamorphic rocks at that time his careful observations led him to suggest many conclusions which have since been confirmed. His most striking mistake, which was shared by his contemporaries in the region, was his failure to interpret the meaning of granitic intrusions parallel to the foliation of gneisses and schists. One noteworthy advance of Percival's over previous knowledge of metamorphic rocks was his recognition of a parallel structure differing from stratification.

In 1895 Prof. N. S. Shaler ${ }^{4}$ commented briefly on the general region in a report published by the United States Geological Survey.

No further work in the area received publication until 1896, when Prof. J. F. Kemp ${ }^{5}$ made a brief study of the Lantern Hill quartz, and presented a paper on it before the New York Academy of Sciences. Only an abstract of the paper was published. (See p. 136.)

\section{AREAL GEOLOGY.}

The rocks of the area (see Pl. II) comprise one complex of metamorphic sedimentaries, two intrusive igneous masses, intrusive sheets accompanying each of the latter, and the great Lantern Hill quartz. Bedrock is, in many critical places, hidden by broad stretches of glacial drift, and the best evidence obtainable at such places is inconclusive; but rock exposures in general are sufficiently abundant to reveal the true geologic relations.

\footnotetext{
1 Shepard, C. U., A report on the geological survey of Connecticut, 1837.

2 Op. cit., p. 30.

- Percival, J. G., Report on the geology of Connecticut, 1842.

4 Shaler, N. S., Preliminary report on the geology of common roads of the United States: Fifteenth Ann Rept. U. S. Geol. Survey, 1895, p. 289.

- Kemp. J. F., The great quartz vein at Lantern Hill, Mystic, Conn., and its decomposition (abstract): Trans. Now York Acad. Sci., vol. 15, 1896, p. 189.
} 


\section{ROCKS OF SEDIMLENTARY ORIGIN.}

TYPES.

The metamorphic sedimentary rocks include the following formations: A quartzite, a coarse-grained gray quartz-biotite schist, a feldspathic schist or gneiss, a fine-grained hornblende schist, and a dolomite. The hornblende schist and feldspathic schist are characterized in the northwestern quarter of the area by interbeds of the black pseudoporphyritic plagioclase-garnet-biotite schist, kinzigite. All the schists are in places filled with granite stringers and become injection gneisses. No direct evidence exists within the area for the determination of geologic age, but correlations given below, based on lithologic and geographic evidence, assign the rocks provisionally to the Cambrian and Carboniferous. The boundary between Carboniferous and Cambrian in eastern Connecticut has not yet been definitely determined.

On the "preliminary geological map of Connecticut" all the formations recognized by the present writer in the following pages, except the quartzite, were included in the Putnam gneiss, ${ }^{1}$ a broad band extending from Norwich and Preston northward into Massachusetts. The data then available were based largely on the writer's reconnaissance work, which was not sufficiently detailed to warrant in this area the subdivisions now made.

The typical Putnam gneiss is dark gray and is extremely variable in texture. Much of it is pseudoporphyritic, like the kinzigite. It is largely feldspathic, but contains many hornblendic and quartzitic layers, varying from a few inches to several feet in thickness. It is also much injected by granitic sheets and stringers. The northward continuation of this gneiss into Massachusetts is represented by the Bolton gneiss, which is assigned by Emerson and Perry to the Carboniferous. ${ }^{2}$

\section{QUARTZITE.}

The quartzite occupies a small area in Voluntown and North Stonington townships. It extends northward from Pendleton Hill in two slightly diverging bands, which form the limbs of a synclinal fold. Its northward and southward extents are obscured by drift. It appears to grade upward and downward into the gray quartzbiotite schist and to lie wholly within the latter, but the lithologic difference between the two is so marked that they are colored separately on the map ( $\mathrm{Pl}$. II, in pocket).

Near the northeast corner of Wyassup Lake, in North Stonington, angular blocks of quartzite are found. These show no evidence of ice transportation and are undoubtedly the broken surfaces of outcrops scarcely showing above the drift.

1 Gregory, H. E., and Robinson, H. H., Bull. Connecticut Geol. and Nat. Hist. Survey No. 7, 1907, p. 36.

2 Geology of Worcester, Mass., 1903, p. 129. 
A band of impure quartzitic rock, at first believed to be a part of the same quartzite, outcrops east of Pachaug Pond around Glasgo, and farther south at Ashwillet and Barnes Hill. Outcrops at the two places last named show the rock to be highly contorted and to grade into fine-grained hornblende and quartz-biotite schists. A probable fault crosses the quartzitic band between Ashwillet and Barnes Hill. This band was at first correlated on lithologic evidence with the quartzite, ${ }^{1}$ but structural evidence points to a higher stratigraphic position for the impure quartżitic rock. (See Pl. II, in pocket.)

The impure quartzitic rock, according to Gregory and Robinson, extends northward in a practically continuous band (the Plainfield quartz schist) through the northeast corner of the State into Massachusetts and Rhode Island, but the writer finds it impossible, without considerable further field study, definitely to correlate the rock of the area with that of the latter States. Lithologically, the quartzite of Voluntown closely resembles the Grafton quartzite, assigned to the Cambrian by Emerson and Perry. ${ }^{2}$ The Plainfield quartz schist also accords in many respects with the same authors' descriptions of the Albion schist member of the Grafton quartzite ${ }^{2}$ as well as with the impure quartzite of that formation, but there is at present no complete structural evidence to prove or disprove such correlation.

\section{QUARTZ-BIOTITE SCHIST.}

A coarse-grained gray quartz-biotite schist is the most widely distributed formation. It is largely covered with drift in the northeast part of the area, but forms a broad band extending in a general northerly direction and is thought to underlie a large part of Voluntown township. From Voluntown it extends southwestward in a fairly continuous westward-curving band across North Stonington into Ledyard, where it is again largely hidden by drift. The isolated areas of sedimentary rock in the southern part of the area are all of this gray quartz-biotite schist.

The rock is typically developed in Voluntown and North Stonington. It is composed essentially of quartz and biotite, with more or less feldspar. The biotite varies in amount. At many places it forms distinct black layers along which the rock readily splits; at others it is almost entirely absent and the rock is much harder. A few outcrops contain thin layers of the lime-magnesia silicates, actinolite, and tremolite.

The contacts of the gray quartz-biotite schist with the adjoining sedimentary rocks are all gradational. The typical rock in the

1 Gregory, H. E., and Robinson, H. H., op. cit.

2 Emerson, B. K., and Perry, J. H., The green schists and associated granites and porphyries of Rhode Island: Bull. U. S. Geol. Survey No. 311, 1907, pp. 12-13.

13338 -Bull. $492-12-2$ 
vicinity of Pendleton Hill grades into the quartzite. West of Billings Lake it grades westward into the fine-grained quartzitic rock. A feldspathic phase in Preston grades into a fine-grained hornblende schist, which in turn, in the vicinity of Prentice Mountain, grades into the fine quartzitic rock just mentioned.

The gray quartz-biotite schist, owing to its coarseness of texture and its prominent micaceous layers, disintegrates more rapidly. than the adjacent rocks in the area. This tendency may be seen in a few places in North Stonington, where the schist is completely disintegrated and fine aplite intrusions within it are practically fresh. Its tendency to relatively rapid erosion is also brought out by the fact that throughout the southern part of the area the larger valleys occur along bands of the schist. This latter fact suggests the probability that the drift-filled valleys, like that including Assekonk Swamp in North Stonington, where outcrops are entirely wanting, are largely underlain by the gray quartz-biotite schist. Where the schist outcrops on high land it is either protected by flanking granite sheets or is strengthened by numerous small stringers of granite.

North and south across Preston and Griswold there extends a phase of the quartz-biotite schist generally similar, but more uniformly and more highly feldspathic and very much like gray gneissoid granite in appearance. The presence in it, however, of thin interbedded layers of quartzite, graphitic and slaty material, and impure limestone, together with their gradation contacts, are sufficient to establish its sedimentary origin. It is separated from the typical quartz-biotite schist by a fine-grained hornblende schist of indefinite thickness.

HORNBLENDE SCHIST.

The fine-grained hornblende schist lies in a well-defined narrow band extending southward from Griswold, through the eastern part of Preston and across the northwest corner of North Stonington. This band apparently grades on the west into the feldspathic schist above mentioned, and it is bounded and penetrated on the east by the main intrusive mass of gabbro, which occupies the north-central part of the area. The hornblende schist also lies west of the feldspathic schist. It runs along the west and south of Amos Lake, in Preston, where it is closely associated with the gray quartz-biotite schist and with the black pseudoporphyritic schist (kinzigite) described below. The limits of this area, owing to gradations and glacial covering, are poorly defined.

The hornblende schist varies in grain from almost aphanitic to medium grained. Its mineral composition is usually that of a hornblende gabbro or a diorite, but the vitreous luster of the plagioclase so closely resembles that of quartz that many specimens appear to 
the eye to consist of hornblende and quartz. A small amount of biotite is usually present. Isolated outcrops of the hornblende schist may readily be taken for metamorphosed basic igneous rock, but the gradational contacts suggest a sedimentary origin. Furthermore, the hornblende schist is closely associated with beds of dolomite, and specimens taken at its contact with the latter have an intermediate composition. Interbedded layers of quartzitic and graphitic character are also found in places. In short, the field evidence favors its sedimentary origin as a rock with a composition similar to that of a gabbro-that is, as a basaltic tuff.

Besides the above variations two subdivisions of the hornblende schist, a basic slate and a basic hornfels, deserve special mention.

The only outcrop of the basic slate observed occurs at the gabbro contact, just north of the Lantern Hill ridge, on the road running east to North Stonington village. The rock possesses the general physical characters of a typical slate and shows fine alternations in bedding but has an unusually high specific gravity. Its mineral composition, as shown by the microscope, is similar to that of the hornblende schist, but its microscopic texture resembles that of the black pseudoporphyritic schist (kinzigite). It further resembles the hornblende schist in inclosing a thin bed of very fine quartzite and one of limemagnesia silicates, each about an inch thick.

The basic hornfels is typically developed as included blocks in the gabbro, both in the main mass and in the outlier at Prospect Hill. These blocks range from the smallest fragments to masses several yards in diameter. They, differ from typical hornfels in specific gravity and in mineral composition. The specific gravity, like that of the basic slate, is remarkably high. The mineral composition is in most specimens identical with that of the hornblende schist. Uralitic hornblende and in one specimen bronzite take the place of the biotite of typical hornfels. On the southeastern slope of Prentice Mountain, where isolated remnants of the former cover of the gabbro mass persist, the hornfels, when followed away from the contact, takes on a schistose structure; thin quartzitic interbeds occur, as in the typical hornblende schist. South of Prentice Mountain, and at Barnes Hill, the hornfels grades into the impure quartzitic rock mentioned on page 17. Glacial drift conceals the steps of the gradation, but the hornblendic character of the quartzitic rock is well marked.

Comparison with Emerson and Perry's work ${ }^{1}$ suggests the correlation of the hornblende schist with the Marlboro formation (Cambrian) of Massachusetts and Rhode Island, which consists of chlorite, actinolitic tremolite and talc schists, hornblende schist, and intercalated limestone and dolomite lenses. The finding of a few fragments of talc schist in the drift overlying the hornblende schist, the 
presence of the lime-magnesia silicate layers, and the association of lenses of dolomite all favor this correlation. Structural evidence, however, can be obtained only by careful study of the territory between the area described and the Massachusetts boundary.

\section{BLACK PSEUDOPORPHYRITIC SCHIST (KINZIGITE).}

The black pseudoporphyritic schist (kinzigite), occurring chiefly as interbeds in the upper part of the hornblende schist, is best developed in Preston, along the low hills between Prospect Hill and the westward bend of Quinebaug River. Closely related rock lies west of Prospect Hill and extends southward to the northern boundary of Ledyard. The typical rock consists of a groundmass of biotite, pure to the naked eye, inclosing rounded crystals of garnet $\frac{1}{8}$ inch in diameter and of acidic plagioclase up to $\frac{1}{2}$ inch in length. This mineral composition (biotite, garnet, and plagioclase) is that of typical kinzigite, although the rock from the type locality in Germany has not the pseudoporphyritic character of the Connecticut rock. The typical rock has five variations (pp. 73 et seq.).

The pseudoporphyritic texture suggests a basic igneous rock, but the geologic occurrence, as shown presently, is that of a sedimentary one. Further, some outcrops full of large pseudophenocrysts might be mistaken for biotitic schist thoroughly injected with pegmatite, but no igneous contacts were found to prove them such. On the other hand, the coarse-grained rock grades into finer rock of similar texture, which includes here and there small lenses of sillimanite schist.

At one outcrop, east of the bend in Quinebaug River, two pebblelike inclusions of hornblende schist were found in the kinzigite. This occurrence points to an unconformity, but such a relation is evidently local and exceptional, as in most cases the interbeds were conformable and marked by gradational contacts. The kinzigite occasionally is found more intimately associated with the feldspathic schist of Preston than with the hornblende schist. Its intimate association with both these formations may be due in part to a mingling of the materials forming them; but the evidence as a whole (see p. 74) points to its derivation from the original of the hornblende schist, partly, perhaps, by erosion and redeposition, as suggested by the pebble-like inclusions, but more probably by alteration of certain beds in place.

\section{DOLOMITE.}

Dolomite occurs at various places in and to the north of the area as small lenticular bodies of varying dimensions. The larger of these in their central parts are light colored and free from dark impurities, but their margins, which grade within a short distance into the inclosing schist, have heen largely converted into the lime-magnesia silicates, diopside, tremolite, actinolite, and a nearly black mica. The 
smaller bodies are impure and have been wholly converted into the lime-magnesia silicates, of which actinolite is sufficiently prominent to give the rock a green color.

Just how numerous these dolomite lenses are and through how great a thickness of strata they are distributed is uncertain; but their exposures within the area are few and are confined to a narrow zone of completely folded rock. The most noteworthy is that near the northwest corner of North Stonington, where the old limekiln was operated in the early eighties. Other-outcrops occur to the north in Preston. If the suggested correlation of the hornblende schist with the Marlboro formation proves to be correct, these dolomite lenses may be equivalent to the Smithfield limestone member of the Marlboro formation.

\section{IGNEOUS ROCKS.}

The igneous rocks of the area include the Preston gabbro and the Sterling granite gneiss, both of which intrude the sedimentary rocks. The gabbro and granite are as distinct in their general characters as they are in chemical composition. Their only character in common is that the apophyses of each form sheets parallel to the foliation of the schists. No dikes related to the gabbro have been found extending across the foliation of the schists, and such dikes from the granite are rare and unimportant.

\section{PRESTON GABBRO.}

As the gabbro is typically developed in Preston, it has been named the Preston gabbro. It forms a long, rather irregular mass in the north-central part of the area, covering parts of Preston, Griswold, North Stonington, and Ledyard. It is for the most part of generally oval outline, but terminates to the south in a boot-shaped mass, with the heel at Ayer Mountain and the toe north of Lantern Hill. The upper part of the "boot" is largely hidden by a thin covering of the schistose basic hornfels.

The Preston gabbro is for the most part medium to coarse-grained rock, whose color varies from dark greenish to purplish, according to the relative importance of uralitized pyroxene or purple labradorite. It is characterized by large, poikilitic phenocrysts of diallage, which vary in size and amount. The largest are more than 2 inches long and an inch or more wide and present irregular boundaries owing to partial uralitization along their borders.

The western border of the mass and the portion around Prentice Mountain are characterized by a distinct quartz-hornblende variety of the gabbro. This variety has a fairly pronounced ophitic texture and consists of nearly white labradorite, well-formed hornblende crystals, and minor amounts of biotite and of quartz. Although a 
quartz diorite as regards mineral composition, it has the chemical composition of a gabbro. It is characterized even in considerably sheared specimens by distinctly ophitic texture.

Three minor varieties were noted in the main mass during the study of the thin sections. One of these is a norite, which occupies a very small area in the northern part of the mass. The second is an olivine gabbro, which probably forms minor segregations between Bay and Rixtown mountains. The third is a pyroxenite phase, forming a segregation a few yards in extent on the south slope of the hill west of Bay Mountain. The hornblendic mass contains minor feldspathic and acidic variations near its contacts.

These varieties are attributed to differentiation. The coarsegrained diallage gabbro is the most plentiful, the norite, pyroxenite, and olivine gabbros together comprising but a small percentage of the whole. No sharp contacts between them and the diallage gabbro have been found, and their close resemblance to the latter favors the belief that they are minor segregations. No contacts could be found between the chief variety and the quartz-hornblende gabbro, and the total absence of apophyses of one in the other points to contemporaneous origin for both. The quartz-hornblende gabbro is evidently an upper border facies of the mass and is not primarily due to metamorphism, although metamorphic effects are also evident. (See also pp. 114-119.)

The main mass is accompanied on the west by a few outliers. The most prominent of these underlies Prospect Hill and outcrops to the north as far as the westward bend of Quinebaug River. Two small outliers of uncertain extent lie in the northern part of Ledyard. The "boot" at the southern extremity of the main mass, now partly separated from it by the covering of hornfels and by glacial drift, was probably once a large outlier or branch, to judge from topography and distribution of outcrops; but the intervening rocks have been nearly all removed by erosion. The depression between Prentice Mountain and Ayer Hill favors such an interpretation. All the outliers save the "boot" are of hornblende gabbro with practically no quartz and are considered intermediate between the two principal varieties above mentioned. The "boot" consists of the coarse-grained porphyritic type.

The gabbro is the only rock in the area that does not possess a well-developed schistose structure. Foliation is extreme along shear zones, but is nearly or quite absent in rock 2 or 3 feet to either side. A distinct gneissic structure is a common feature in the outliers and along the hornblendic border of the main mass, owing to the abundance of shear zones and to the greater mashing suffered by the rock as a whole; but it is, even there, far less prominent than in the other rocks of the area. 
The form of the main gabbro mass, from accumulated structural evidence, is that of an immense sill or possibly a laccolith. The silllike character of the outliers is more strongly indicated. Small intrusive sheets of amphibolite are numerous west of the main gabbro mass and near Ashwillet. The coarser-grained sheets clearly possess an igneous texture and a mineral composition suggestive of highly sheared porphyritic gabbro. The finer-grained sheets, in which schistose structure is strongly developed, are similar in appearance to the hornblende schist of the sedimentary series, and can be distinguished from it only by their small width and sharp contacts.

\section{STERLING GRANITE GNEISS.}

The granite gneiss takes its name from the town of Sterling, Conn., which lies north of Voluntown, beyond the limits of the area. The granite lies chiefly in the southern and eastern part and represents the margin of a batholith which underlies a large part of eastern Connecticut and Rhode Island. Its eastern boundary is not yet definitely known, but it is thought to extend eastward as far as the Narragansett Basin in Rhode Island. Its western edge passes southward through Connecticut near the eastern boundary of the State to North Stonington, where it turns westward and is known to continue as far as the town of Salem. The similarity of the Sterling granite gneiss to the pink granites along Long Island Sound suggests that they all belong to one batholith, which extends westward probably as far as the Triassic area in central Connecticut.

Within the area the granite comprises three principal varieties, all gneissoid, which differ in texture and composition. That of the large area along the boundary between Griswold and Voluntown is coarse grained and porphyritic, constituting a typical augen gneiss, with biotite as the chief accessory. Similar rock is found in large masses north of Pitcher Mountain in North Stonington, southeast of Chapman Hill, and in the southwest corner of the area. Smaller outcrops lie west of the gabbro mass.

The hills west and northeast of Lantern Hill contain a more evenly grained gneissoid variety, in which biotite is largely or entirely absent, and which is therefore an alaskite. Other occurrences of this variety are found around North Stonington village and at several points in Griswold and Voluntown. Both the porphyritic and alaskite varieties, from the largest masses down to minor occurrences too small to map, have, like the gabbro, the form of intrusive sheets.

The granite gneiss over an area extending south from Lantern Hill and North Stonington village beyond the limits of the area consists chiefly of a nonporphyritic biotite granite, intermediate in texture and composition between the porphyritic and alaskite varieties. The gneissic structure in the southeast corner of the area and farther south is less marked than elsewhere. 
Pegmatite sheets and stringers are associated with all three varieties of granite. Thair mineral composition is very simple and comprises generally quartz, red and white feldspar, and biotite. Muscovite is not common; tourmaline and garnet are rare; the three, so far as known, are contained only in a white feldspar phase of the pegmatite which forms small intrusions, chiefly in the feldspathic quartz schist. No other characteristic pegmatite minerals were noted. The gradation of pegmatite into quartz veins is common and is especially notable around Glasgo and Lantern Hill.

That the Sterling granite gneiss is younger than the gabbro is proved by the presence in the latter of a very few pegmatite dikes . and stringers, and also by structural evidence (pp. 30-33).

\section{LANTERN HILL QUARTZ.}

The Lantern Hill quartz forms a high, narrow, talus-flanked ridge, $1 \frac{1}{4}$ miles in length and more than 1,000 feet in maximum width, along the western boundary of North Stonington. It is the result of infiltration of quartz and replacement of alaskite along a zone of weakness, and is one of the largest quartz masses known. Other quartz masses of similar origin occur a mile north of Glasgo village in Griswold and in the vicinity of Swantown Hill in North Stonington. (See pp. 135-146.)

\section{STRUCTURAL GEOLOGY.}

\section{SCHISTOSITY.}

Where evidences of stratification, such as calcareous, graphitic, or quartizitic layers are found, the schistosity coincides with them in strike and dip. This relation holds true not only in the limbs but in the arches of small folds. Mica scales lie parallel to the edges of the beds even at the curves of the arches. The same is true of amphibole grains, which have developed parallel to the bedding but many of which lie with their principal axes oblique to strike and dip. The small folds are, almost without exception, overturns, pitching steeply north and dipping west. The limbs of many dip $45^{\circ}$ or less.

The parallelism of mineral grains to bedding is of interest, as it is commonly held that schistosity develops in a plane normal to the maximum component of compressing forces, regardless of stratification. Thus, if schistosity is parallel to the bedding along the limb of a fold, it is not expected to follow the curve at the arch. But although it may not follow it in isoclinal folds in which there is no sliding of the beds over one another at the arches, the evidence at hand shows that it does follow it in overturns. In the latter the arches at the time of folding are being constantly pushed away from the direction of thrust, and the beds are sliding or "flowing" over one another not only along the limbs, but at the arches as well. Mica flakes developed along one limb would lie and travel in the direction 
of the flowage or sliding, and, on reaching the arches, would continue to migrate around the curve to the other limb. When movement should cease, those flakes which had just reached the arch would remain parallel to the curvature or to their final direction of movement.

Hornblende crystals would behave in the same manner, though to a less degree, since their ability to transform under pressure is, as Leith has shown, ${ }^{1}$ not so great as that of biotite. The oblique position of the hornblende is evidently due to the fact that the movement of the beds over one another was oblique to the axes of the folds.

This agreement between schistosity and bedding was found in small or minor folds, but no opportunity

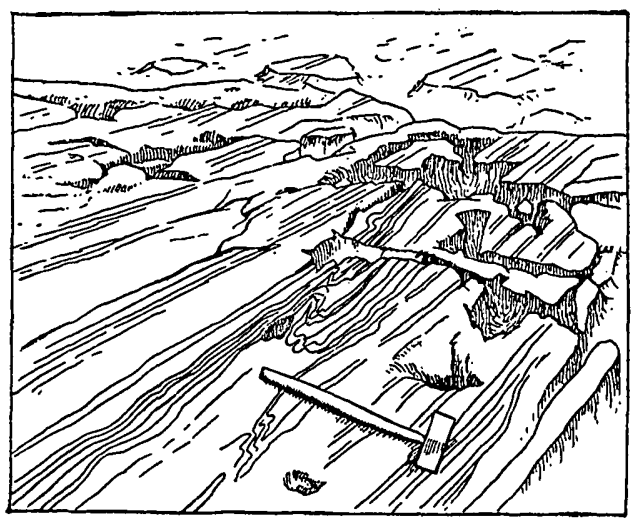

FIGURE 2.-Overturned minor undulations, or crumplings, in schist. was found to study the relations in principal folds, as no axes of the latter were well exposed.

FOLDING.

\section{UNDULATIONS.}

The sliding of the beds over one another was accompanied by miniature folds or undulations oblique or in many places nearly normal to

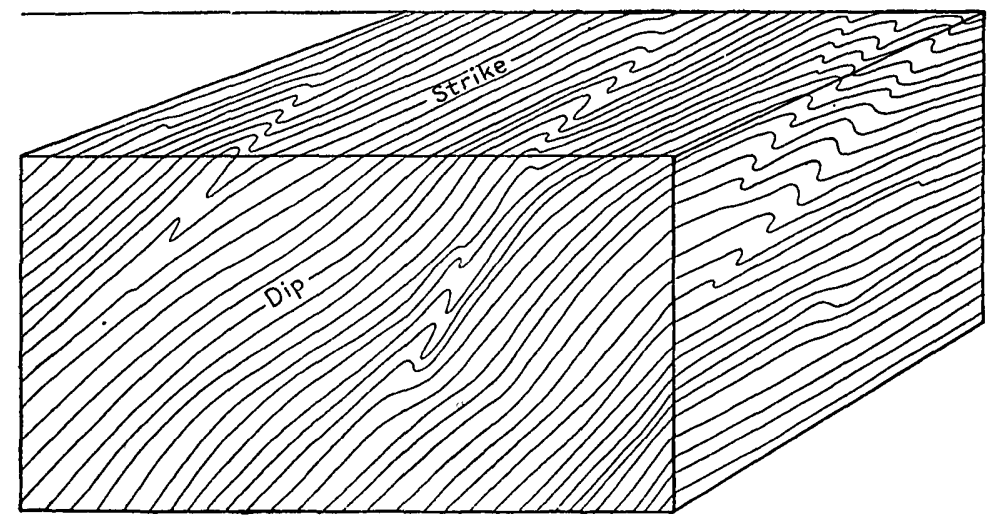

FrGURE 3.-Minor undulations, mostly normal or oblique to general strike and dip.

the general strike and dip. Some examples of these undulations may be compared to gentle waves from a few inches to a foot or more in length; more commonly they are sharp overturns (figs. 2 and 3), 
and a few are even overthrusts. The abundance of these miniature overturns is evidence that the rocks must have been rendered very plastic under the pressure that produced metamorphism and folding.

MINOR FOLDS.

The data for determining folds are very incomplete. Wherever strike and dip can be observed in the northern half of the area, the

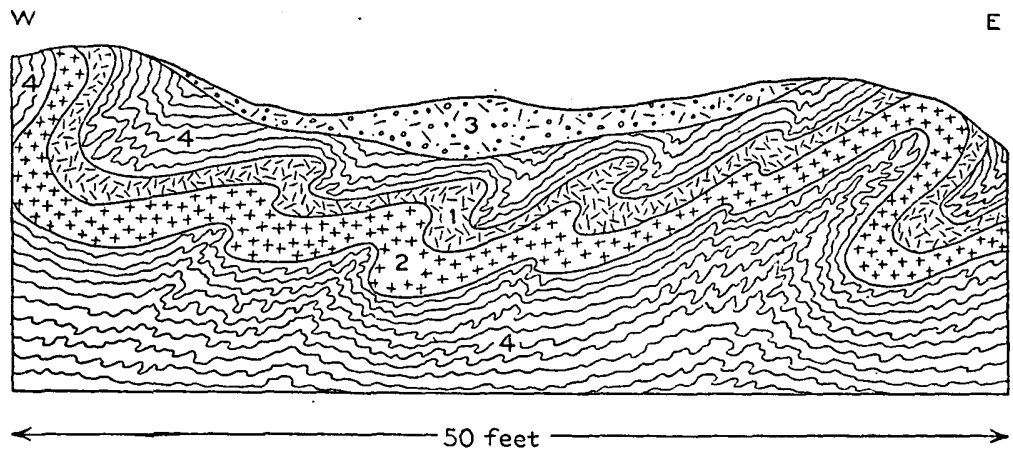

FTaURE 4.-Folding inferred from relations of pegmatite and amphibolite sheets. 1, Pegmatite; 2, amphibolite; 3 , till; 4 , feldspathic schist.

strike is practically parallel to the periphery of the gabbro, and the dip is almost invariably to the west. (See Pl. I.) Most outcrops are monoclinal, though a few present minor folds.

The following examples of minor folds will give some idea of the difficulty of identifying larger folds. Figure 4 is a sketch inferred

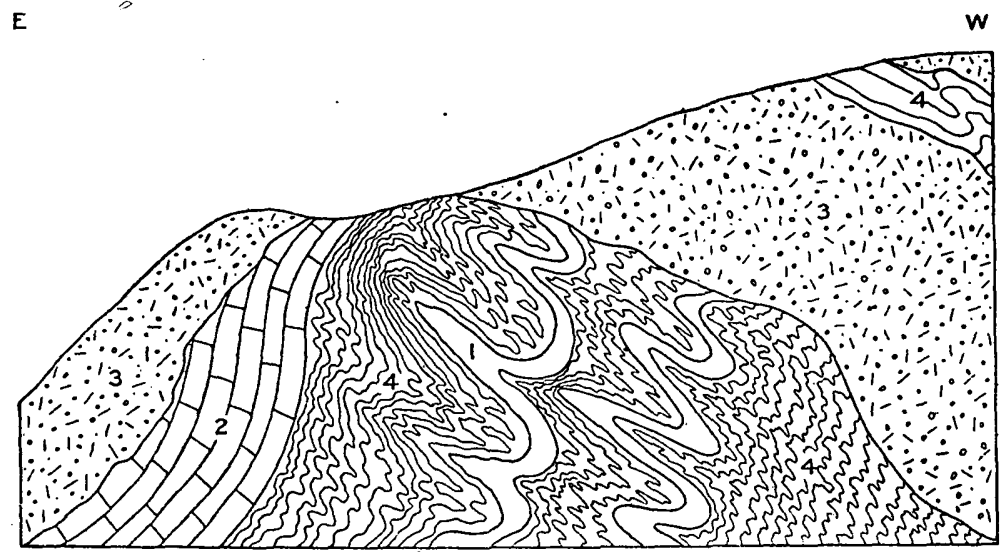

8 feet

FraURE 5.-Crumpled schist within fold of rigid lime-silicate rock. 1, Crumpled schist; 2, lime-silicate rock; 3, till; 4, feldspathic.schist.

from the association of a pegmatite sheet with one of amphibole, $1 \frac{1}{2}$ miles northeast of Preston. The country rock is a feldspathic schist of uniform character, showing no evidence of folding on its nearly horizontal surface. The fairly uniform western dip and the 
relative positions of the pegmatite and amphibolite sheets suggest an overturn, or very possibly several overturns.

Figure 5, drawn to scale, from an exposure in the same locality as that represented in figure 4, shows a portion of a small fold of highly crumpled schist within a relatively rigid arch of a lime-silicate bed. The lime-silicate bed is not found exposed elsewhere in the vicinity, though much thicker blocks of limestone are found in talus less than half a mile to the southeast. The uncertainty of such an attempt at correlation needs no further comment.

Figure 6, a tracing from the photograph of an outcrop a short distance south

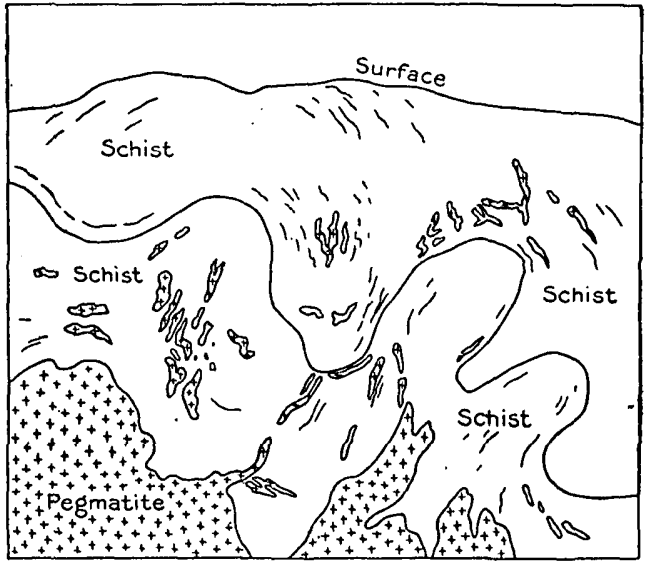

FrGURE 6.-Small fan-shaped fold in schist near North Stonington limekiln.

of Geer's limekiln, shows a small, fan-shaped fold crossed by aplite stringers. The rock is schist of uniform character, and gives no evidence on its horizontal surface of folding, but appears on its vertical face to be much folded. The small size of the outcrop prevented the tracing of the fold further than is shown in the figure.

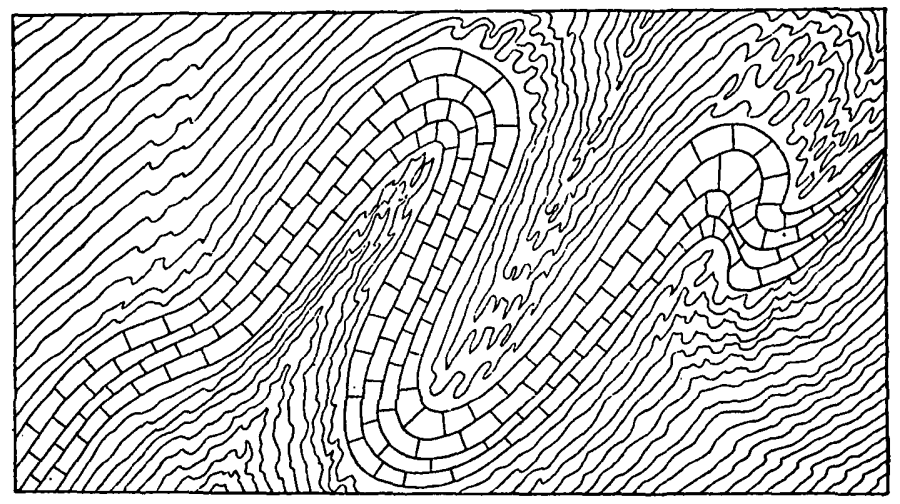

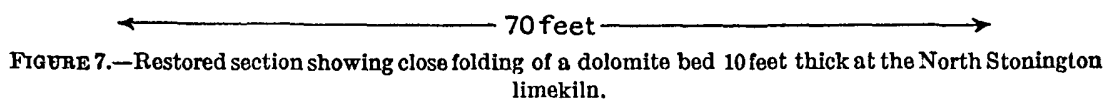

The best example of folding is at Geer's old limekiln, near the northwest corner of North Stonington (fig. 7), where a bed of dolomite, 10 feet thick, has been folded into two anticlines and two synclines within a distance of about 75 feet. The details of the folds were made clear by the excavation of the limestone, and the 
several limbs of limestone undoubtedly belong to the same bed. The schist outcropping on the hill just west of the limekiln is of uniform character, as in the other localities just described, and gives no clue to the highly folded character of the region.

From these and other similar examples, taken from numerous scattered localities, it seems probable that the sedimentary rocks are highly folded throughout. Folding, however, can be definitely detected only in some distinct bed, such as the dolomite; and if the outcrops of such a bed are found a considerable distance apart it may be impossible to prove that both outcrops belong to a single bed, or to ascertain how many folds may lie between the two exposures.

\section{MAJOR FOLDS.}

The distribution of the several sedimentary rocks gives some indication of folding on a much larger scale, but the uniformity of dip in the limbs and, usually, the lack of exposed axes leave doubt as to the exact nature of the fold-whether anticlinal or synclinal. The most definite example of a major fold occurs northeast of Pendleton Hill, along the eastern border of the area, where its existence is evident from the alternating position of bands of yellowish quartzite and gray quartz-biotite schist. The quartzite bands unite east of Pendleton Hill and mark the axis. The dips of the west limb (see Pl. I, in pocket) are very steep to the west; those of the east limb less steep; the strike is slightly west of north. The dips measured near the axis are rather gentle ( $30^{\circ}$ and less) to the north and northwest. These data, though not very abundant, indicate an overturned syncline with a northerly pitch.

If the fold were a simple syncline, the limbs, consisting of such hard rock, should be traceable northward until they either converged or reached the axis of an anticline; but this can not be done. The geologic map (Pl. II, in pocket) shows that what few exposures lie north of the mapped quartzite are either gray quartz-biotite schist or granite. No evidence has been found that the quartzite limbs have been cut off by a fault. The only possibilities remaining are that the western limb of the syncline either suddenly pinches out or that it is in reality an anticlinal axis, the quartzite being overlain to the west and north by quartz-biotite schist (Pl. II, section A-A). The latter alternative seems the more probable and its acceptance permits the correlation of the quartzite areas close by Wyassup Lake.

The latter small, poorly defined exposure may be regarded as the barely exposed crest of an anticline, concealed to the northeast and southwest by the quartz-biotite schist. If it were a remnant of a syncline it would be more likely to occur along the top of a ridge flanked by gray quartz schist than in a valley. Further evidence is 
concealed by the broken character of the outcrops and the extensive covering of drift. If it is an anticline there is no structural evidence to prevent the correlation shown in sections A-A and D-D, Plate II.

The distribution of the hornblende schist west of the gabbro mass also indicates folding. From the dips taken collectively the eastern band of hornblende schist appears to pass under the feldspathic schist to the west and to form the east limb of a syncline. The extensive drift covering throughout Preston Plains conceals the probable axis and obscures the west limb. The hornfels at Prospect Hill may be part of the western limb. It is possible, owing to the scarcity of outcrops in certain places (Pl. III, in pocket), that some of the bands correlated above as parts of one bed may in reality belong to separate beds; but in so highly folded a region it seems equally if not more reasonable to regard them as parts of the same bed. The gradational character of many outcrops renders the drawing of distinct boundaries difficult and uncertain. This is especially true of the kinzigite and the hornblende schist.

ARRANGEMENT OF FOLDS.

Although folding in the area is due primarily to regional movement, the arrangement of the folds is thought to have resulted largely from the local effect of the gabbro mass. The schistose rocks throughout the greater part of eastern Connecticut strike north, or a little east of north, and dip west at a practically constant angle. Within the area, however, only the schistose rocks in the northwest quarter conform to this strike and dip. In the northwest quarter the principal fold is a syncline in relatively flexible schist between two more rigid bodies-the main gabbro mass on the east and the group of outliers on the west. The axis of this syncline is parallel to the western boundary of the main gabbro mass. These relations indicate that the eastward thrust that produced the folding tended to force the slightly yielding gabbro outliers forward over the more yielding schists. The form of the resulting syncline was determined by the barrier of the main gabbro mass. In the rest of the area the strike is mostly parallel to the periphery of the main gabbro mass, and the dip, with a few local exceptions, is toward it. Southwest of the gabbro the rocks with eastward strike and northward dip swing northward to join those with northward strike and westward dip. The meeting point is in the vicinity of Shewville. To the north of here the dip is westward, to the southeast it is northeastward; but the scarcity of outcrops at this critical point obscures the relations. The interpretation of the folding based on these very meager data is given in Plate IV (in pocket), which shows Shewville to lie on an anticline starting from a mere point and widening southward into diverging folds. 


\section{ORIGIN OF FOLDS.}

\section{EFFECT OF THE GABBRO INTRUSION.}

When the whole region was subjected to dynamic metamorphism the principal compressive force was such as to produce the westwarddipping overturns; that is, it was the equivalent of an eastward or nearly eastward thrust. (See fig. 10, A, B.) That the compressive force was not so great in the southern quarter of the area as it was farther north is shown by the different amounts of mashing suffered by granite areas. Specimens from the northern half, especially west of the gabbro, are severely mashed, but those from near Lantern Hill and farther south are only moderately crushed. One specimen from a quarry in Westerly, $2 \frac{1}{2}$ miles south-southwest from the southeast

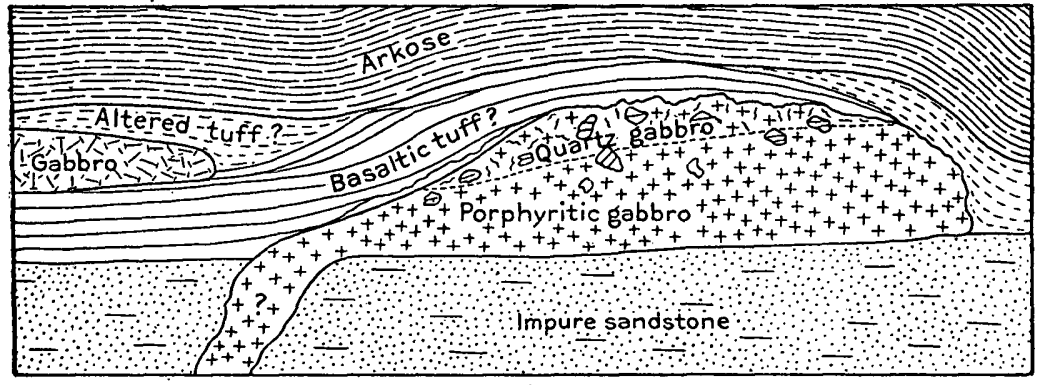

A

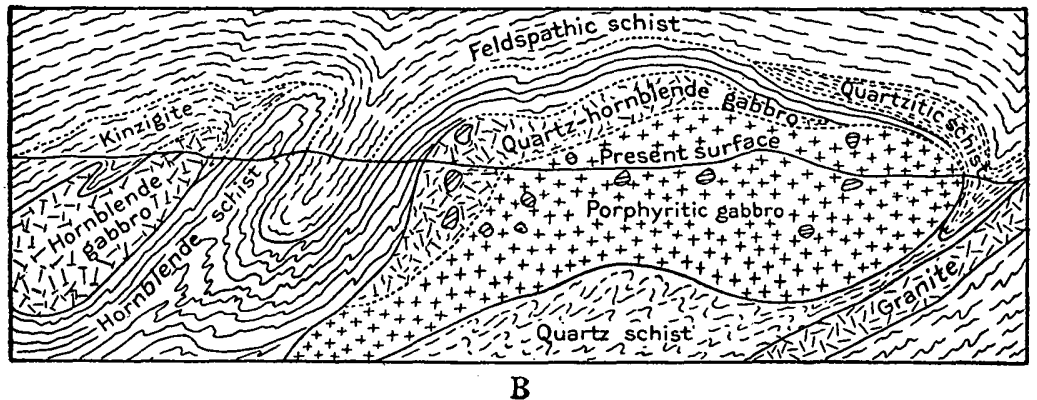

FIgURE 8.-Probable sill-like form of gabbro mass: A, Before folding; B, after folding.

corner, was practically free from mashing, although its minerals showed undulatory extinction in thin section. (See p. 126.)

The gabbro was intruded prior to regional metamorphism (see pp. 33-39) in a mass approximating an immense sill, or possibly a laccolith, producing domal uplift (fig. $8, \mathrm{~A}$ ). If this mass were acted upon by an eastward thrust, the effect would tend to shorten its east-west and to lengthen relatively its north-south diameter. The directions of the resultant forces that would be developed within the mass are indicated in figures 9 and 10. Where these forces were upward, the tendency to upward flowage in the gabbro. would tend to elevate the dome still more; but where resultant components acted horizontally, the 
lateral deformation of the gabbro would tend to produce folds parallel to the contact. If these laterally transmitted thrusts were great enough, they would produce overturns striking parallel to and dipping toward the periphery of the gabbro.

But the actual force acting on the surrounding strata would be the resultant between regional movement and the secondary force transmitted by the gabbro. Close to the contact, the secondary force would prevail, but only for a short distance; whereas the regional movement would become more and more manifest as the distance from the contact increased. The result would be an anticline, with limbs diverging southward, developed southwest of the gabbro, and a

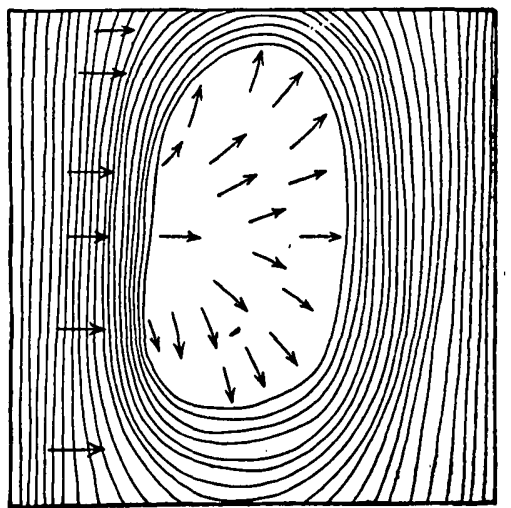

Figure 9.-Simplified plan of gabbro mass, showing results of eastward compression. similar one, diverging northward, to the northwest of the gabbro (fig. 10, $\mathrm{A}$ ). These anticlines would, theoretically, begin at a point and expand rapidly. If the folding were sufficient to develop small overturns within these anticlines, the latter would become anticlinoria.

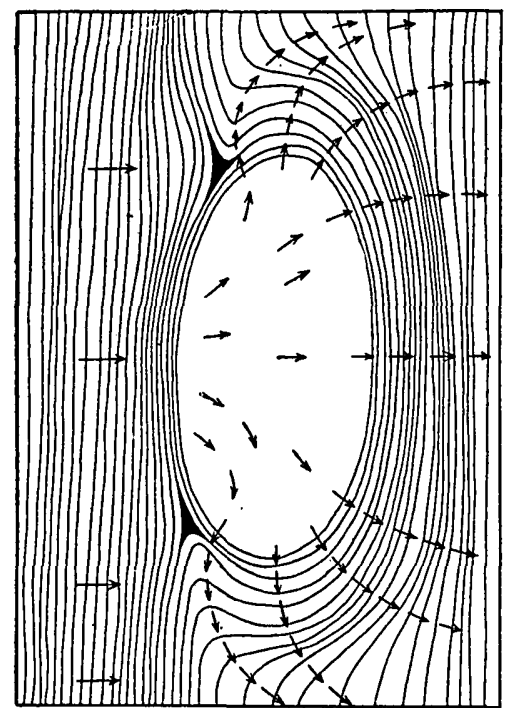

A

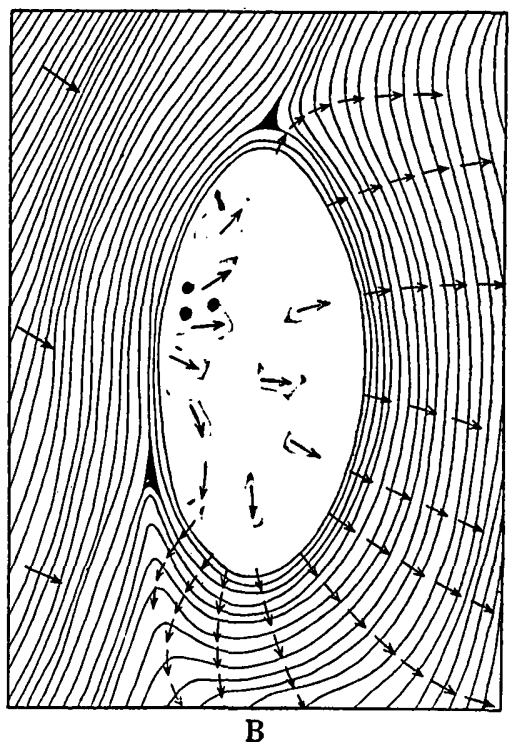

B

FIGURE 10.-Effects of transmitted force on schists: $A$, Compression from the west; $B$, Compression from the west-northwest.

Figure 10, A, represents the theoretical results that would be seen if the regional thrust acted in an eastward direction; figure 10, B, represents the results of a thrust in an east-southeast direction. 
Figure 10, B, shows a strong though far from perfect resemblance to Plates I and IV. The drift cover north of the gabbro conceals all evidence of the supposed local anticline to the north, but the few outcrops around Shewville and just to the northwest of Ayer Hill distinctly suggest the postulated anticline to the south.

But as the gabbro shows very little gneissic structure, save close to its borders, its north-south elongation can not have been great, and its transmitted thrust must have been far too slight to have alone effected the bordering rocks to so great a distance from its contact as they have been affected. Some additional pressure must have been acting with it, and this pressure was evidently supplied by the Sterling granite gneiss.

EFFECT OF THE GRANITE INTRUSION.

The granite occupies the greater part of the area to the south and is much more abundant to the east than to the west of the gabbro. The period of the granite intrusion (see pp. 43 and 127), as a whole, coincides with that of the folding. At that time the relatively rigid sill-like gabbro mass acted as a barrier to intrusion from below, and diverted the granite mostly to the sedimentaries on the south and east. The secondary thrusts exerted by the gabbro would be sufficient to determine the direction of intrusion of the fluid or viscous granite, and the latter, coming in enormous sheets, would force the strata apart and increase the extent of the gabbro's influence many times. The total effect would be as if the gabbro mass had been larger and more thoroughly compressed.

Further study to the north, west, and south must be made to prove that the strikes and dips in those places conform to their theoretical positions. To judge from the trends of the elliptical hills, which generally conform to the strike, the relation holds good, but actual proof is lacking.

The fact that the granite found the easiest paths of intrusion to the south and east of the gabbro, suggests that the latter extends to the west and north for some distance, acting as a barrier to large granite intrusions in those directions. If it does so extend, the strata around its northern border overlie the gabbro and are above the level at which the local anticlines would be likely to form. The strikes of the few outcrops northeast and northwest of the gabbro agree with such a relation.

SUMMARY.

Regional movement acted in an east-southeast direction; the resistant gabbro mass set up, locally, secondary radiating lines of movement which tended to produce folds parallel to its periphery. These secondary lines and the position of the gabbro determined the 
directions of the granite intrusions that accompanied the regional movement; the granite intrusions greatly accentuated the amount of the secondary local movement, producing the results shown in Plate IV. Further discussion of the origin of the folds and of the regional metamorphism is postponed until after the petrographic descriptions of the gneissoid granite. (See pp. 38-44, 127-131.)

\section{IGNEOUS INTRUSIONS.}

\section{PRESTON GABBRO.}

The Preston gabbro occupies a roughly oval area in the northcentral part of the area. Outliers occur to the west, and thin sheets and stringers appear both to the west and the east of the main mass. The gabbro is clearly intrusive into the surrounding sedimentaries, as is shown by the intrusive sheets, and especially by the hornfels contacts and inclusions. The contact, so far as actually exposed, is coincident with the strike and dip of the sedimentaries, and the intrusion, to judge from the relations around Prentice Mountain (Pl. IV), produced a domal uplift.

It is impossible to determine the exact form of the intrusive gabbro, but the evidence suggests an immense sill-like body. The dips near the western edge of the gabbro (see Pl. IV) are nearly or quite vertical, whereas those farther to the west are more and more gentle and incline away from the gabbro. The few readings taken at Ashwillet, near the east border, show the dip to be about vertical close to the gabbro, and only $30^{\circ}$ or less half a mile from the contact; but on this side the dip is toward the gabbro. At Prentice Mountain, the isolated areas of hornfels dip $20^{\circ}$ to $50^{\circ} \mathrm{S}$., or away from the center of the gabbro. From the evidence thus far given, the structure may be interpreted as that of a laccolith, so compressed during regional metamorphism that the east and west slopes of the dome contact have become vertical (fig. 8, B), and the slope of the roof contact at Prentice Mountain has been steepened and complicated.

But the contact south of Prentice Mountain and west of Swantown Hill extends across the strike, and the contact with the basic slate, north of Lantern Hill, though parallel to the strike, dips $60^{\circ}$ toward the gabbro mass. If, then, the gabbro has a laccolithic form from Prentice Mountain north, this form is broken by the arm of it to the south, which forms the boot-shaped mass of which Ayer Hill is the heel.

The Ayer Hill mass topographically resembles a northward-dipping sill, but general absence of outcrops along its southern border prevent definite determination. The fact that the nearest schists to the south dip toward it suggests its sill-like form.

13338 - Bull. $492-12-3$ 
No evidence of a floor to the gabbro was discovered, and it is therefore impossible to prove beyond dispute its further resemblance to a laccolith; but the distribution, as well as the strikes and dips of the granite sheets around it, suggests that its underground vertical extent is not great; that it slopes toward the northwest; and that it becomes thinner, or pinches out, in that direction. The large granite sheets are limited to the south and east and dip toward the gabbro; sheets of any considerable size to the west and northwest are few and dip away from it. Granite intrusions into the gabbro are few, being limited, so far as observed, to two pegmatite dikes each about a foot in width and to a few aplite stringers. These intrusions occupied nearly vertical fissures near the border of the mass. The betterdefined pegmatite dike lies at the northwest base of Rixtown Mountain.

If the gabbro extended downward or had a vertical contact to the east and south, and if the granite were erupted through it into the schists, it would be difficult to explain the absence of granite dikes in the gabbro area. It is more plausible to imagine the granite on the south and east as following upward along the vertical contact for some distance and then suddenly turning outward along some plane of easy parting in the schist; but it seems probable that a part of the intrusions would have followed the contact farther and have appeared at the present surface.

Though the last hypothesis may be considered possible, it seems to the writer less probable than the supposition that the floor of the gabbro mass was rather gently inclined $\left(30^{\circ}\right.$ to $40^{\circ} \mathrm{W}$., to judge from dips in surrounding rocks) and acted during regional compression as a barrier to the upward course of the granite; that the latter became deflected in a direction about parallel to the gabbro floor and emerged as immense sheets in the neighboring schist to the south and east. The presence of the smaller granite sheets to the west of the exposed gabbro area suggests that the gabbro either thins in that direction and is more easily penetrated, or that it pinches out completely.

The evidence as a whole favors a sill-like form for the main mass. Its remnants of dome-shaped cover suggest a laccolith, but its irregularity of contact in its southern and southeastern portions do not justify its interpretation as so simple a form. Some of these irregularities in the contact, however, may be due to faulting caused by the gabbro during intrusion (p. 50).

The sill-like forms of the best-exposed western outliers are more clearly defined, not only topographically but structurally. The overlying schistose hornfels may be found in direct contact parallel to the dip, and the underlying beds, dipping under the gabbro, are exposed within a few feet or a few yards. 


\section{STERLING GRANITE GNEISS.}

INTRUSIVE AREAS.

The Sterling granite gneiss is confined principally to the southern third of the area and to one important intrusion east of the gabbro. Minor intrusions are scattered throughout the sedimentary area.

The granite areas comprise rocks of three varieties-porphyritic, alaskitic, and intermediate (or normal). They are intrusive into both the metamorphosed sedimentary rocks and the Preston gabbro. That all the intrusions are in the form of sheets or sills, although their superficial areas alone do not in all cases suggest such a form, will be best understood by considering them in groups according to the variety of the rocks composing them.

Porphyritic granite gneiss areas.-The only one of the four large areas of porphyritic granite that gives positive evidence as to its method of intrusion is that which lies east of the gabbro in Voluntown and Griswold. It narrows and pinches out both to north and south and its schistosity agrees in strike and dip with that of the surrounding schists. The only exposed contact was found on the northeast shore of Billings Lake, where the coarse-grained, gneissoid granite, presenting many minor contortions or overturns along its schistosity, overlies medium to fine grained schist. No contact of the granite with overlying schist was exposed, but outcrops of light to dark quartzitic schist flank its western border both at its northern and southern extremities and conform to
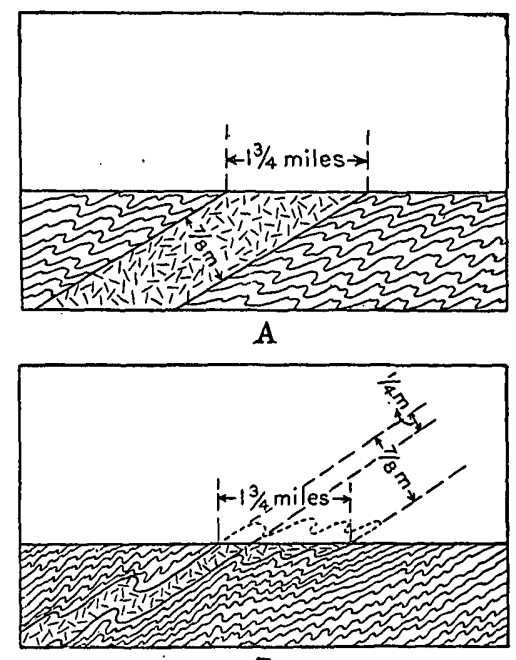

B.

FIGURE 11.-Thickness of porphyritic granite sheet in Griswold: A, Apparent thickness; $B$, probable thickness. its schistosity in strike and dip. This evidence, though not abundant, is sufficient to identify the granite body as a large intrusive sheet.

The broad, rounded shape of the granite area does not at first suggest the form of a sheet, but the westward dip of schistosity in the widest part is gentle, $30^{\circ}$ or less, and the breadth of the area is due to the low inclination of the sheet. The dip of the easternmost outcrop is very gentle to the northeast. The maximum width of the area is $1 \frac{3}{4}$ miles. If the sheet were free from folds, the maximum thickness, calculated from a $30^{\circ}$ dip, would be about seven-eighths of a mile. The presence, however, in the granite of contortions identical with those so numerous in the neighboring schist and the north- 
eastward direction of dip at its eastern margin lead to the belief that the actual thickness is considerably less than that given above. (See fig. 11.) The presence of the contortions in the porphyritic granite proves that, although the rock had been intruded before folding had ceased, it was still sufficiently plastic to be plicated without fracture, save for the granulation of its minerals. The relation between the time of intrusion and that of folding will be further considered in connection with the petrography of the granite. (See p. 130.)

Alaskite areas.-The alaskite variety is best developed in a long ridge which extends in an eastward direction across the central part of Ledyard to Lantern Hill. It continues northeastward from that point in two parallel bands, outcropping on Wintechog, Swantown, Stewart, Cossaduck, and Chapman hills, and finally splits into several thick sheets, which project into the schist around Wyassup and Billings lakes and Pendleton Hill. Good exposures of alaskite occur elsewhere in the quadrangle, but not so continuously.

No contacts of the large mass of alaskite with the neighboring schists were found, but the position of the alaskite ridge (see Pls. II and III) is very significant. The trend of the ridge is parallel to the strike of the schist; the schistosity of the alaskite agrees in strike and dip with that of the schist; and, finally, the alaskite in some places lies between parallel areas of schist. The only plausible conclusion is that the alaskite ridge is an enormous intrusive sheet, left in relief and isolated by erosion and glaciation. Its sheeted form is most evident in the northern band between Swantown Hill and Billings Lake. It is also suggested in Ledyard and in the smaller area which lies between areas of porphyritic granite and schist at North Stonington village. This latter may be a branch from the main sheet.

Normal granite gneiss areas.-Definite evidence has not been found as regards the form of the masses of the normal granite. This variety occurs only at the southern end of the area and is largely concealed by glacial drift. Its schistosity at North Stonington village conforms in strike and dip to that of the east-west band of schist, but no further relations have been discovered. In many isolated outcrops of schist seen in the granite area beyond the southern limit of the area the schistosities of the two rocks coincide. Thus it seems probable that the sheet-like relation prevails between the normal granite and the schists, although the predominance of granite is far too great to permit its being described as a group of sheets. These areas probably mark the gradation upward from the batholith proper into sheets which gradually pinch out between schist layers. If such be the fact, the main granite batholith is barely exposed in the area, which is traversed by a broad sheeted contact zone more or less well defined. 
Minor sheets and dikes.-The minor intrusive sheets of granite require little mention save that they are of all three varieties and of pegmatite as well. True dikes are very scarce. Figure 12, a tracing from a photograph, illustrates the only noteworthy occurrence of a granite intrusion cutting across the foliation in an overturned syncline of hornblendic kinzigite. At the base of the ledge the granite cuts squarely across the foliation, and its right-hand contact continues across it until near the top of the ledge. Its left edge, however, swings toward the horizontal a short distance above the base and follows the schistosity along the synclinal curve to the top, where the dike becomes a sheet. Small stringers from the dike follow the foliation, converting the schist into an injection gneiss. This small dike, cutting across the arch of a syncline and then following along the limb as a sheet, is a miniature example of the large sheet of porphyritic granite (p. 35) as interpreted in section $\mathrm{A}-\mathrm{A}$, Plate II. The only other intrusions across the schistosity noted are narrow aplite and pegmatite stringers. The presence of a small, nearly vertical pegmatite dike and of a few aplite stringers in the gabbro has already been mentioned (p. 34).

Structural interrelations of the granite intrusions.-The relations of the intrusions of the three varieties of the

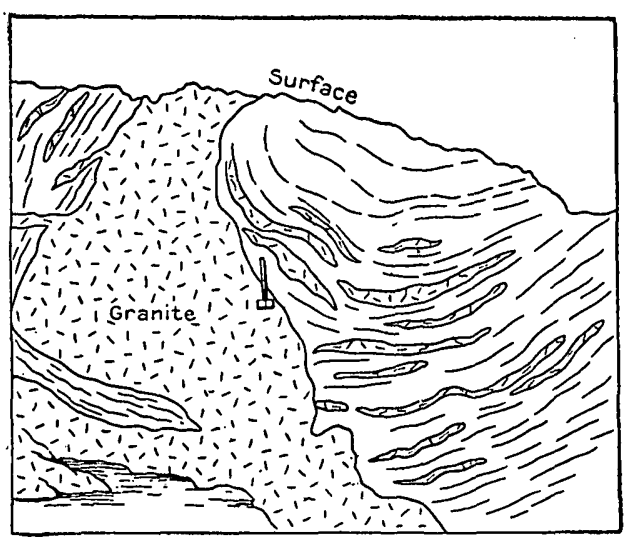

FIGURE 12.-Granite dike crossing syncline in hornblendic kinzigite and sending stringers along foliation. granite to one another are, from the evidence at hand, typical of granite masses. Porphyritic texture is common in many dikes and sheets elsewhere. The structural relation between the porphyritic and the normal varieties is not clear. Textures gradational between the two were found, but no intersection of one by the other is known. It is, therefore, probable that both varieties belong to the same period of eruption and that the porphyritic rock is more characteistic of the intrusive sheets and the normal granite of the batholith proper.

The structural relations between the alaskite and the other two varieties is more definite. Typical alaskite was not discovered in direct contact with the porphyritic granite, but a 5 -inch dikelet of it was seen cutting the normal variety $1 \frac{1}{2}$ miles west of North Stonington village. Small fine-grained dikes of mica-free aplite occur both in the porphyritic and intermediate varieties, but none were 
seen in the typical alaskite. This strongly suggests that the alaskite and mica-free aplite differ only in granularity and belong to a single period of eruption following that of the porphyritic and normal granite. The fact that some specimens were found gradational in mineral composition between alaskite and the normal granite raises the question whether these two may not be in part contemporaneous. All the three varieties are cut by pegmatite.

\section{METHOD OF INTRUSION.}

The batholith evidently slowly worked its way upward by sending out into the overlying schist sheets which in turn put forth minor sheets. Where different sheets united, surrounding a block of schist, the latter was engulfed and replaced by material of the batholith. Thus the batholith proper followed its advance guard of sheets, working upward until solidification took place. Erosion has since progressed in the southernmost portion of the area and beyond far enough to expose the upper portion of the batholith proper and the roots of a few sheets, and in the northern portion to expose the major and minor sheets; showing that the batholith proper is but a short distance below.

Nearly every outcrop of the sedimentary formation contains one or more intrusions from the granite. The intrusions are phanerocrystalline, save in some of the smallest stringers, which are aplite, and many are of considerable size. This signifies that the temperature of the invaded rock must have been nearly at the fusing point of granite and is further evidence that the batholith, from which the heat was derived, can not be far below the present surface. Similar evidence from a large part of eastern Connecticut, as well as from the area discussed, suggests that the present surface rocks form but a thin, ruptured cover over a very extensive granite batholith. It appears, to judge from the diminishing size of the intrusive sheets northwestward, that the surface of the batholith proper slopes downward in that direction.

\section{METAMORPHIC DEFORMATION.}

\section{REGIONAL METAMORPHISM OF THE PRESTON GABBRO.}

That the gabbro intrusion preceded regional metamorphism is shown by the characteristic metamorphic effects which it presents. Owing to its massive character, it was not so readily affected by compression as were the loose-textured sedimentaries around it. Gneissic structure, therefore, is marked only near the borders and even there is not universally present, being limited to bands or zones. The quartz-hornblende gabbro along the western border in general presents a distinct though not excessive gneissic structure, mostly 
parallel to the contact, where the vertical sedimentaries were pressed against it. Again, the coarse-grained porphyritic gabbro at Ayer Hill has a decided foliation in a north to northeast direction. This foliation gives ground for the conclusion that the gabbro mass as a whole was somewhat narrowed and lengthened by compression.

Gneissic structure in the central part of the area can not be seen on horizontal surfaces, but here and there a slight but distinct horizontal foliation is discovered on a vertical exposure. This evidence, indicative of vertical compression, further confirms the hypothesis illustrated in figure 8, A and B (p. 30). It also suggests that the present outcrops in which they appear were not far below the eroded cover. The compression of the gabbro and its effect upon the surrounding rocks (see p. 30) may be compared to that of a partly mashed pebble in a metamorphic conglomerate. The domal form of the gabbro mass (p. 33) best suits this comparison.

But, though the gabbro was too rigid to suffer distinct flowage throughout its mass, it yielded at several places to shearing stresses (Pl. I). The rock was so plastic under the high temperature and pressure then existing that flowage, instead of fracture, took place along these shear planes, and the coarsest-grained rock may be seen to grade abruptly into a narrow zone of highly schistose amphibolite. Observations of this shearing were too few and small to show any definite relation to the direction of regional compression.

The minerals of the gabbro show the characteristic strain effects common to those in basic rocks which have solidified and cooled previous to metamorphism. In such rocks the secondary minerals, epidote, scapolite, and uralite, are characteristic, whereas, in rocks that solidified during or just before shearing and were still close to their fusing points, the original minerals are not replaced, although they may be highly granulated, as in the Canadian anorthosites described by Adams. ${ }^{1}$

\section{CONTACT METAMORPHISM DUE TO THE PRESTON GABBRO.}

The contact metamorphism produced by the gabbro consisted principally in the conversion of the invaded rock into hornfels-a simple recrystallization without any conspicuous additions from the magma. The typical basic hornfels is found, not in the surrounding rock, but as inclusions of different size in the gabbro. Between the interior of the gabbro area and its western border many small inclusions of hornfels, showing little or no sign of stratification or foliation and resembling dense trap, are seen. Near the border, these inclusions are very large and in several places form the greater part of an outcrop. At the border they are still more numerous, uniting

\footnotetext{
1 Adams, F. D. Ueber das Norian oder ober-Laurentian von Canada: Neues Jahrb., Beil. Bd. 8, 1893, p. 462.
} 
to form hornfels ledges cut by many gabbro stringers that run in different directions, with no definite system. Beyond the border the hornfels texture is gradually obscured and finally obliterated by a schistose structure, and the hornfels grades into hornblende schist. This gradation may be seen at Rattlesnake Rocks on the northwest border and at Prentice Mountain. At these places instead of a sharp contact line there is a contact zone in which the predominating rock gradually changes from gabbro to the basic hornfels.

The formation of the hornfels prior to regional compression would seem reasonable, even without the observed metamorphic effects in the gabbro. If the rock had been transformed into a schist prior to the gabbro intrusion, it is probable that a magma so highly liquid as that of gabbro would have followed the planes of schistosity to a marked degree and that the included masses would have their schistose structure preserved by frequent parallel stringers of gabbro, but

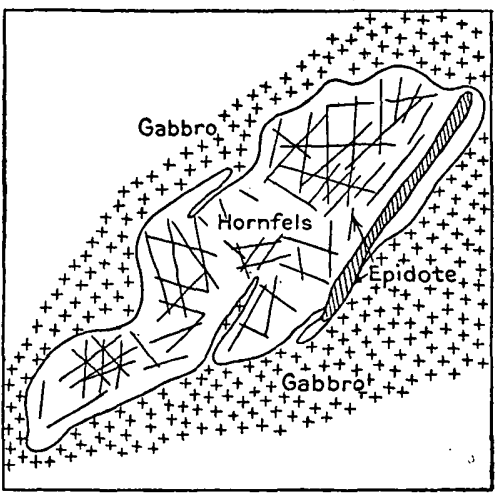

FigORE 13.-Hornfels inclusion in gabbro. no uniform evidence of such a condition is obtainable. On the other hand, the hornfels inclusions, instead of showing any tendency to foliation, generally show excessive jointing in several directions. The joints are confined to the inclusions, are filled with epidote veinlets and gabbro stringers, and are so arranged as to resemble shrinkage cracks (fig. 13). They suggest that the heat from the gabbro produced shrinkage and tended to expel the included water; but, as there was no escape for the water through the molten gabbro, its presence favored the formation of epidote veinlets in the hornfels, which, as the microscope shows, contains as much lime, iron, and alumina, as the gabbro itself. The magma also could furnish water for the formation of the epidote and thus supplement the water originally in the hornfels.

This evidence of contact metamorphism agrees with that of regional metamorphism in showing the intrusion of the gabbro to have preceded regional compression. The hornfels inclusions in the gabbro (fig. 13) are in decided contrast to a block of typical hornblende schist, found just north of Broad Brook, included within a granite sheet. The molten granite, to judge from the medium-grained texture of many of its stringers, was in all probability intruded at a higher temperature than was the molten gabbro, yet it did not destroy the schistose structure. The gradation of hornfels into hornblende schist outside the gabbro is regarded as being due to the effect of regional pressure, which could 
PLATE V. 


\section{PLATE V.}

A. Photomicrograph of epidote gneiss. The two light bands are highly quartzose granite stringers. The dark bands are schist, consisting chiefly of epidote and sericitized plagioclase, moderately impregnated with small (white) quartz grains and larger flakes of biotite. Magnified 30 diameters. With crossed nicols. Section 134.

$B$. Photomicrograph of part of a diallage phenocryst inclosing labradorite and ilmenite. The light streaks across the diallage are minute shear zones of uralite. The largest feldspar clearly shows the incipient development of epidote around its contacts with both diallage and ilmenite. Of the two ilmenite grains, one is anhedral and interpenetrating with diallage. Magnified 30 diameters. Nicols crossed. Section 1. 


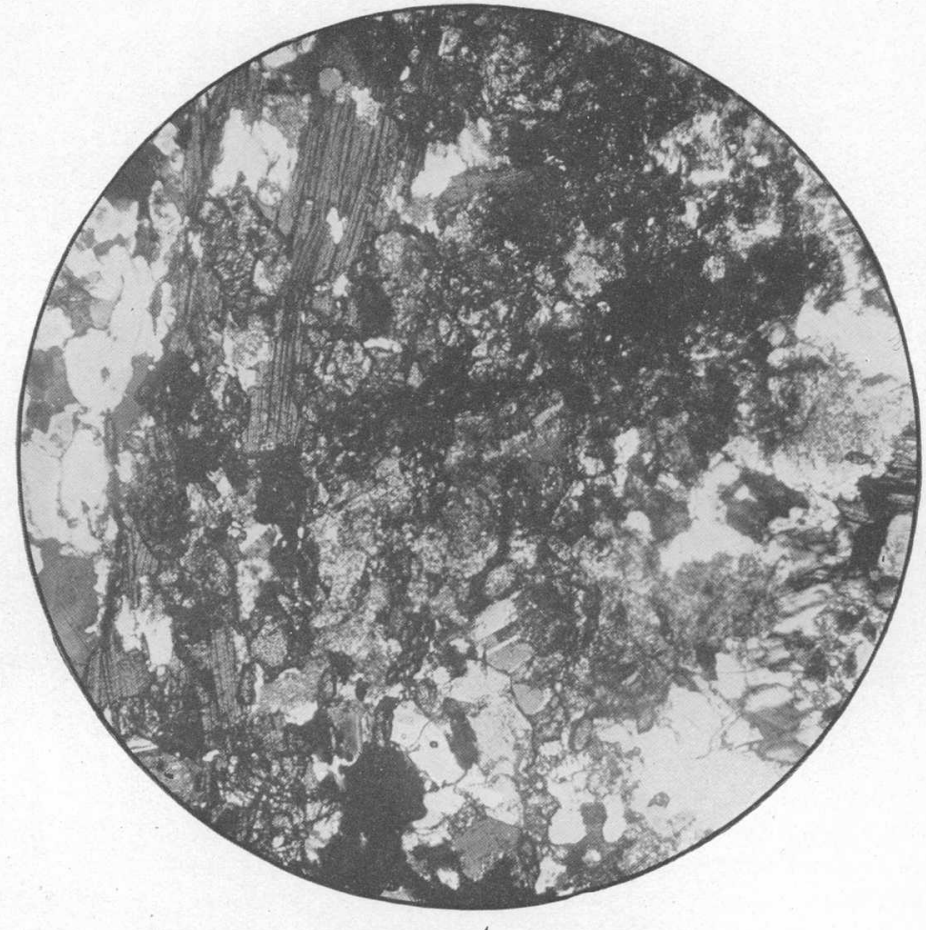

A.

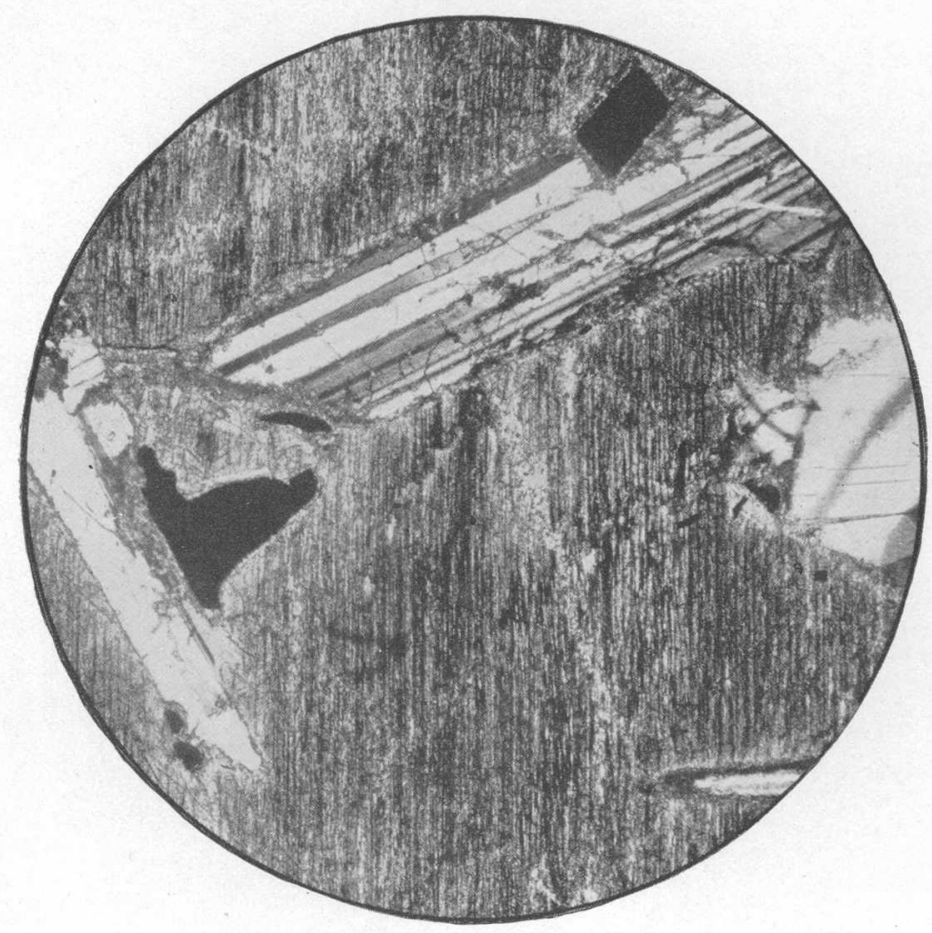

B. 
affect the outer border of hornfels but could not so alter the protected inclusions within the gabbro.

REGIONAL METAMORPHISM OF THE STERLING GRANITE GNIISS.

The gneissoid structure of the granite, conforming with that of the sedimentary rocks throughout the area, and the mashed character of its minerals as seen under the microscope, show that the granite was intruded early enough to be influenced by the regional compression; but the presence in the porphyritic granite of minor contortions identical with those seen in the sedimentaries points to the fact that the granite must have been sufficiently plastic at the time of compression to be locally plicated without fracture. This renders it probable that the porphyritic granite was intruded during the period of folding. It has already been shown (p. 37) that the alaskite was intruded later than the porphyritic granite, and it will be demonstrated later (p.129) from microscopic evidence that the alaskite was barely solidified when movement due to regional compression ceased. The pegmatite, intruded later than the alaskite, must in general have followed the period of compression. Its general freedoin from crushing effects agrees with this conclusion.

\section{CONTACT METAMORPHISM DUE TO THE STERLING GRANITE GNEISS.}

No development of hornfels was noted in connection with the granite, and the evidence (p. 40) shows that recrystallization and schistose structure in the sedimentaries had been developed before the intrusion of the granite. The only noted contact effect produced by the granite was a thorough injection accompanied by some pneumatolytic action, by which the adjacent schist became so altered in character as nearly to conceal its identity.

It has already been stated that the only exposed contact of the large granite areas is at Billings Lake, where a large sheet of porphyritic granite overlies the gray schist. The schist in the immediate vicinity is full of aplitic intrusions but is easily recognizable save in the small area within 50 to 75 feet of the porphyritic granite. Close to the porphyritic granite the rock in this area is a nonporphyritic gneissoid granite containing greenish lenticular inclusions of schist, several inches in length, lying along the schistosity planes. Nearer the unaltered schist these inclusions are increasingly smaller but more numerous, until they equal the granite in amount, and the rock becomes a gneiss composed of short alternating bands of epidotic and quartzose material-an epidote gneiss. (See Pl.V,A.) Further gradation can not be traced, as the ledge disappears beneath the water. A petrographic description of the epidote gneiss is given on page 61 .

A similar occurrence of epidote gneiss lies about a mile northeast of the above exposure along the contact of the sheet, where the road 
from Pendleton Hill crosses a steep brook valley. This exposure lies close to the porphyritic granite but is separated from the schist by the valley, and no direct evidence of transition can be obtained.

\section{JOINTS.}

\section{DISTRIBUTION AND DIRECTIONS.}

The distribution and directions of the joints observed in the ares are shown geographically on Plate I (in pocket), in radiating plan in Plate VI, and by a curve, figure 14, based on the accompanying table. The most striking fact shown in Plate I when compared with Plate II (in pocket) is the general absence of joints from the granite area in Voluntown. Outcrops are plentiful, but joints are few, owing probably to the massive character of the rock as compared with the adjacent schists. The other blank areas in Plate I represent driftcovered districts.

If the directions plotted should be continued across the plate they would resolve themselves into more or less definite systems; but there would be many intermediate directions that would be equally near to two systems. For this reason an attempt to determine definite systems by lines parallel to the directions plotted was abandoned.

A more accurate method is that of Spurr, ${ }^{1}$ who plotted the several directions from a common center (Pl. VI). This arrangement conceals any local variations and shows no sharply defined systems; but, if viewed from a short distance, it shows a marked north-south concentration, a less marked east-west one, and several poorly defined intermediate groups. Natural limits to these groups or systems are very obscure or are entirely wanting.

This obscurity was overcome to a great extent by tabulating the number of joints within arcs of $10^{\circ}$ and plotting the results graphically. To prevent any error by dividing a group which lay partly in two arcs, two tables were made; one with arcs taken in even multiples of 10 $(0-10,10-20$, etc.) and one with arcs lying midway between (5-15, $15-25$, etc.).

1 Spurr, J. E., The ore deposits of Monte Cristo, Wash.: Twenty-second Ann. Rept. U.S. Geol Survey, pt. 2, 1901, p. 810 . 


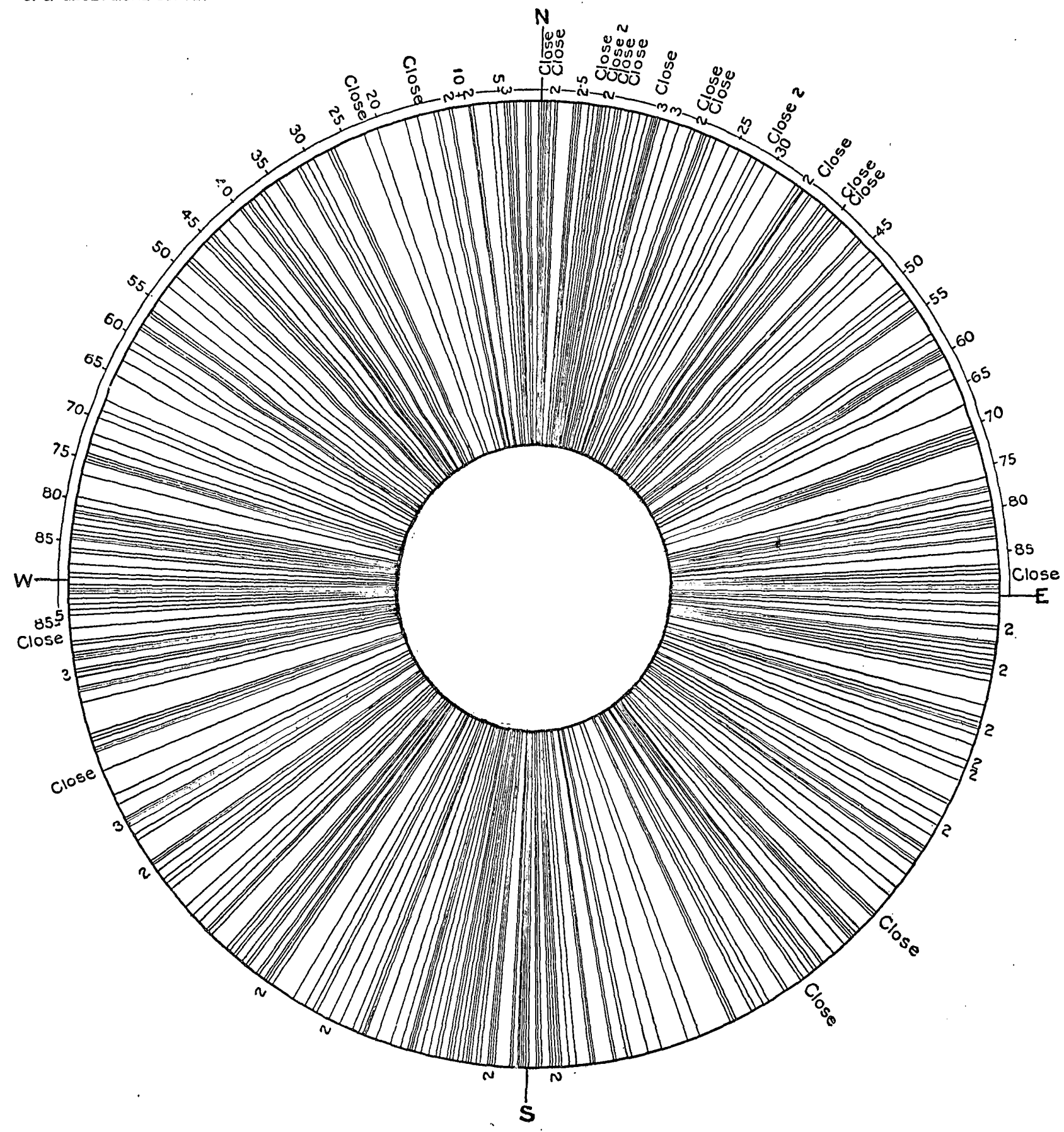

PLAN OF JOINT DIRECTIONS.

Numbers nearest margin indicate parallel joints recorded. "Close," close or sheet jointing. 


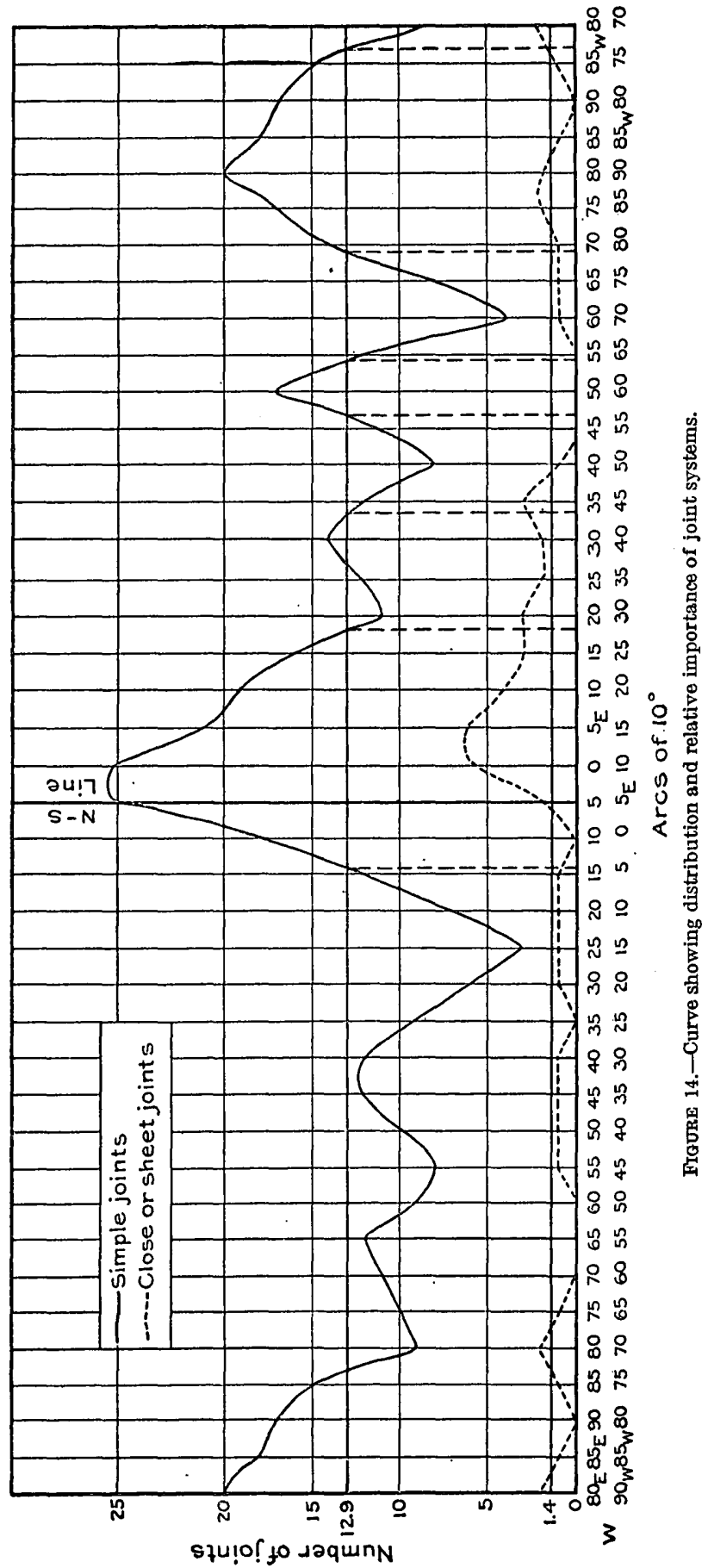


Direction of joints grouped in arcs of $10^{\circ}$.

\begin{tabular}{|c|c|c|c|c|c|}
\hline \multicolumn{3}{|c|}{1} & \multicolumn{3}{|c|}{2} \\
\hline Arc. & $\begin{array}{c}\text { Number } \\
\text { of } \\
\text { joints. }\end{array}$ & $\begin{array}{l}\text { Number } \\
\text { of close or } \\
\text { sheeted } \\
\text { joints. }\end{array}$ & Arc. & $\begin{array}{c}\text { Number } \\
\text { of } \\
\text { joints. }\end{array}$ & $\begin{array}{c}\text { Number } \\
\text { of close or } \\
\text { sheeted } \\
\text { joints. }\end{array}$ \\
\hline $\begin{array}{c}\text { N. } 90^{\circ}-80^{\circ} \mathrm{W} . \\
80^{\circ}-70^{\circ} \\
70^{\circ}-60^{\circ} \\
60^{\circ}-50^{\circ} \\
50^{\circ}-40^{\circ} \\
40^{\circ}-30^{\circ} \\
30^{\circ}-20^{\circ} \\
20^{\circ}-10^{\circ} \\
10^{\circ}-0^{\circ} \\
0^{\circ}-10^{\circ} \mathrm{E} . \\
10^{\circ}-20^{\circ} \\
20^{\circ}-30^{\circ} \\
30^{\circ}-40^{\circ} \\
40^{\circ}-50^{\circ} \\
50^{\circ}-60^{\circ} \\
60^{\circ}-70^{\circ} \\
70^{\circ}-80^{\circ} \\
80^{\circ}-90^{\circ}\end{array}$ & $\begin{array}{r}17 \\
9 \\
11 \\
9 \\
10 \\
12 \\
6 \\
7 \\
18 \\
25 \\
19 \\
11 \\
14 \\
8 \\
17 \\
4 \\
14 \\
20\end{array}$ & $\begin{array}{c}2 \\
\ldots \ldots . . \\
\cdots \cdots \cdots \\
1 \\
1 \\
1 \\
1 \\
\cdots \cdots \\
6 \\
4 \\
3 \\
2 \\
1 \\
\cdots \cdots \\
1 \\
1 \\
2\end{array}$. & $\begin{array}{cc}\text { N. } 85^{\circ} \mathrm{E} .-85^{\circ} \mathrm{W} . \\
85^{\circ} \mathrm{W} .-75^{\circ} \\
75^{\circ}-65^{\circ} \\
65^{\circ} & -55^{\circ} \\
55^{\circ} & -45^{\circ} \\
45^{\circ} & -35^{\circ} \\
35^{\circ} & -25^{\circ} \\
25^{\circ} & -15^{\circ} \\
15^{\circ} & -5^{\circ} \\
5^{\circ}-5^{\circ} \mathrm{E} . \\
5^{\circ} \mathrm{E} .-15^{\circ} \\
15^{\circ} & -25^{\circ} \\
25^{\circ} & -35^{\circ} \\
35^{\circ} & -45^{\circ} \\
45^{\circ} & -55^{\circ} \\
55^{\circ} & -65^{\circ} \\
65^{\circ} & -75^{\circ} \\
75^{\circ} & -85^{\circ}\end{array}$ & $\begin{array}{r}18 \\
15 \\
10 \\
12 \\
8 \\
12 \\
9 \\
3 \\
12 \\
25 \\
21 \\
16 \\
12 \\
12 \\
11 \\
12 \\
8 \\
17\end{array}$ & \begin{tabular}{c}
1 \\
1 \\
1 \\
\hdashline 1 \\
1 \\
\hdashline 1 \\
1 \\
2 \\
6 \\
3 \\
2 \\
3 \\
$\cdots$ \\
\hdashline 1 \\
2
\end{tabular} \\
\hline $\begin{array}{c}\text { Total........ } \\
\text { Average per arc }\end{array}$ & $\begin{array}{l}233 \\
12.9\end{array}$ & $\begin{array}{l}26 \\
1.4\end{array}$ & & $\begin{array}{l}233 \\
12.9\end{array}$ & $\begin{array}{l}26 \\
1.4\end{array}$ \\
\hline
\end{tabular}

Direction of axes of tributary valleys grouped in arcs of $10^{\circ}$.

\begin{tabular}{|c|c|c|c|c|c|}
\hline \multicolumn{2}{|c|}{ Major tributaries. } & \multicolumn{4}{|c|}{ Minor tributaries. } \\
\hline \multicolumn{2}{|l|}{3} & \multicolumn{2}{|l|}{4} & \multicolumn{2}{|l|}{5} \\
\hline Arc. & Axes. & Arc. & Axes. & Arc. & Axes. \\
\hline $\begin{array}{c}\text { N. } 90^{\circ}-80^{\circ} \mathrm{W} . \\
80^{\circ}-70^{\circ} \\
70^{\circ}-60^{\circ} \\
60^{\circ}-50^{\circ} \\
50^{\circ}-40^{\circ} \\
40^{\circ}-30^{\circ} \\
30^{\circ}-20^{\circ} \\
20^{\circ}-10^{\circ} \\
10^{\circ}-0^{\circ} \\
0^{\circ}-10^{\circ} \mathrm{E} . \\
10^{\circ}-20^{\circ} \\
20^{\circ}-30^{\circ} \\
30^{\circ}-40^{\circ} \\
40^{\circ}-50^{\circ} \\
50^{\circ}-60^{\circ} \\
60^{\circ}-70^{\circ} \\
70^{\circ}-80^{\circ} \\
80^{\circ}-90^{\circ}\end{array}$ & $\begin{array}{l}2 \\
0 \\
0 \\
2 \\
2 \\
0 \\
3 \\
5 \\
8 \\
5 \\
6 \\
1 \\
1 \\
1 \\
0 \\
2 \\
2 \\
1\end{array}$ & $\begin{array}{c}\text { N. } 90^{\circ}-80^{\circ} \mathrm{W} . \\
80^{\circ}-70^{\circ} \\
70^{\circ}-60^{\circ} \\
60^{\circ}-50^{\circ} \\
50^{\circ}-40^{\circ} \\
40^{\circ}-30^{\circ} \\
30^{\circ}-20^{\circ} \\
20^{\circ}-10^{\circ} \\
10^{\circ}-00^{\circ} \\
0^{\circ}-10^{\circ} \mathrm{E} . \text {. } \\
10^{\circ}-20^{\circ} \\
20^{\circ}-30^{\circ} \\
30^{\circ}-40^{\circ} \\
40^{\circ}-50^{\circ} \\
50^{\circ}-60^{\circ} \\
60^{\circ}-70^{\circ} \\
70^{\circ}-80^{\circ} \\
80^{\circ}-90^{\circ}\end{array}$ & $\begin{array}{r}2 \\
1 \\
2 \\
0 \\
3 \\
4 \\
3 \\
10 \\
7 \\
6 \\
7 \\
7 \\
3 \\
2 \\
2 \\
5 \\
5 \\
5\end{array}$ & $\begin{array}{cc}\text { N. } 85^{\circ} & \mathrm{E} .-85^{\circ} \mathrm{W} . \\
85^{\circ} & \mathrm{W} .75^{\circ} \\
75^{\circ} & -65^{\circ} \\
65^{\circ} & -55^{\circ} \\
55^{\circ} & -45^{\circ} \\
45^{\circ} & -35^{\circ} \\
35^{\circ} & -25^{\circ} \\
25^{\circ} & -15^{\circ} \\
15^{\circ} & -5^{\circ} \\
5^{\circ} & -5^{\circ} \mathrm{E} . \\
5^{\circ} & \mathrm{E}-15^{\circ} \\
15^{\circ} & -25^{\circ} \\
25^{\circ} & -35^{\circ} \\
35^{\circ} & -45^{\circ} \\
45^{\circ} & -55^{\circ} \\
55^{\circ} & -65^{\circ} \\
65^{\circ} & -75^{\circ} \\
75^{\circ} & -85^{\circ}\end{array}$ & $\begin{array}{r}3 \\
1 \\
2 \\
1 \\
0 \\
7 \\
2 \\
7 \\
6 \\
10 \\
6 \\
6 \\
5 \\
3 \\
2 \\
3 \\
4 \\
7\end{array}$ \\
\hline $\begin{array}{l}\text { Total....... } \\
\text { Average per arc. }\end{array}$ & $\begin{array}{l}40 \\
2.2\end{array}$ & & $\begin{array}{l}75 \\
4.2\end{array}$ & & $\begin{array}{c}75 \\
4.2\end{array}$ \\
\hline
\end{tabular}

Figure 14 shows a principal system close to the north-south line, a secondary system close to the east-west line, and four minor systems in directions approximating N. $60^{\circ} \mathrm{W}, \mathrm{N} .40^{\circ} \mathrm{W}$, , N. $35^{\circ}$ E., and N. $55^{\circ} \mathrm{E}$. These directions agree very well with those given by Hobbs ${ }^{1}$ for Connecticut, especially in the western crystalline area. The

1 Hobbs, W. H., 'Twenty-first Ann. Rept. U. S. Geol. Survey, 1901, p. 101; Jour. Geology, vol. 9, No. 6, 1901, p. 471; Bull. Geol. Soc. America, vol. 15, 1904, pp. 483-506; Trans. Wisconsin Acad. Sci., Arts, and Let., vol. 15,1905 , p. 27. 
systems, however, are not sharply defined; on the other hand, the interspaces are much more distinct. Another feature is the lack of symmetry in the two largest systems. Both bulge decidedly to the right, and are separated from the two succeeding minor systems by minor interspaces. The first system, though concentrated slightly to the east of north, extends over an arc of $55^{\circ}$; the second system, though concentrated slightly to the north of east, extends over $50^{\circ}$. Expressing these relations in percentages, the north-south system comprises 34 per cent of the total number of joints within 31 per cent of the $180^{\circ}$ arc; the east-west system 27 per cent within 27 per cent of the $180^{\circ}$ arc. The predominance is better shown if the extent of the systems is limited to those parts of the curve above the average line, 12.9. The north-south line now comprises 32 per cent in 22 per cent of the $180^{\circ}$ arc, and the east-west system 24 per cent in 19 per cent. The N. $35^{\circ} \mathrm{E}$. system comprises 6 per cent in 6 per cent, and the N. $55^{\circ} \mathrm{E}$. system 7 per cent in 6 per cent, whereas the two northwest systems fail to reach the average line. The remaining 31 per cent of the joints are scattered over 47 per cent of the circumference. These figures bring out the fact that the four recognized systems are not sharply defined, but extend over more than half the $180^{\circ}$ arc.

The close or sheet jointing curve agrees with that of simple jointing only within the principal system. The remainder shows irregularities and depressions within the rises of the simple jointing curve; but the general lack of agreement may well be due to the small number of close joints observed.

Although none of the systems are sharply defined, it must be remembered that the data has been taken from a small area, several portions of which were concealed by drift. Conclusions based on this data should, therefore, not be ascribed to too great an area. A greater number of observations within the area, or additional observations over a more extensive area, might materially change the curves, especially as regards the minor systems now poorly defined; but the curve at present is sufficient to establish the location of the two principal systems, even though they are not so sharply defined as additional data might show them to be.

\section{ORIGIN OF JOINTS.}

With data from so small an area, only tentative conclusions can be drawn. The first question is whether the joints could have been developed during the great regional movement. The folding throughout the schistose areas is so close that joints probably could not have formed at the time of folding, although the development of foliation planes would produce potential planes of parting between different beds or along strata rich in mica or hornblende. 
If the same movement had continued after diminution of temperature aided by erosion had brought the rocks into the zone of fracture, yielding would have taken place most readily as thrust faults along the potential planes of parting; but, while the existence of thrust faults in the area is possible, none have been observed. It therefore seems more probable that the joint systems were developed by some later force or forces, either torsional, as shown by Daubrée, ${ }^{1}$ Crosby, ${ }^{2}$ and Van Hise, ${ }^{3}$ or shearing, as shown by Hobbs. ${ }^{4}$

But the later force or forces, although acting after the folded rocks had been brought into the zone of fracture, may not have greatly postdated the period of folding. In fact, the occurrence of the quartz veins with replacement of the wall rock at Lantern Hill and similar places indicates that the north-south and probably the eastwest joint systems were formed during or before the pneumatolytic period of the granite intrusion. The directions of the joints indicate that the torsional or shearing axis was diagonal to the general strike of the folds. Further conclusions from the evidence at hand are not warranted.

No conclusive proof was discovered regarding the relative ages of the minor joint systems. Their poorly defined character may be due either to their being merely secondary joints generated by the shearing movement that produced the principal systems ${ }^{4}$ or to their being the result of later and weaker stresses.

\section{REIATION OF JOINTS TO STREAM COURSES.}

The influence of joints in determining stream courses is obscured by the fact that the most strongly developed joint system is, to a very large extent, nearly or quite parallel to the strike of the foiiation; a fair idea of it, however, may be gained by comparing the trends of the valley axes with those of the joints.

PRINCIPAL VALLEYS.

The independence of the principal valleys in regard to the joint directions is marked, only two of the seven valleys conforming to the principal joint systems. These two are the Pachaug, at Glasgo, and the Mystic, south of Lantern Hill. The Pachaug (see Pl.II, in pocket) cuts directly across the strike of the massive porphyritic granite sheet from one band of soft rock to another and may well have been aided by the east-west jointing. The Mystic Valley follows a southerly direction, wholly in gneissoid granite, along a zone of close, or sheet, jointing. Its trend is entirely independent of the strike of the

1 Daubrée, A., Géologie expérimentale, Paris, 1879, pp. 306-314.

2 Crosby, W. O., The origin of parallel and intersecting joints: Am. Geologist, vol. 12, 1893, pp? 368-375.

${ }^{3}$ Van Hise, C. R., Principles of pre-Cambrian North American geology: Sixteenth Ann. Rept. U. S. Geol. Survey, pt. 1, 1896, pp. 668-670.

- Hobbs, W. H., The Newark system of the Pomperaug Valley, Conn.: Twenty-first Ann. Rept. U. S. Geol. Survey, pt. 3, 1901, p. 120. 
foliation. It seems only reasonable that, as the rock is of uniform hardness, the river should take advantage of the zone of weakness.

Pachaug River, save at the one point mentioned, does not conform to the jointing. East of Glasgo the heavy mantle of drift conceals the rock structure, and the river flows along an old lake floor. The trend of the valley conforms to the strike of the foliation and the position of a band of soft rock, as well as to the jointing. The valley of Pachaug Pond follows the northeastern boundary of the main gabbro mass and is developed in an area of soft rock. It coincides with the strike, but is quite independent of joint directions. The Quinebaug in the northwest corner follows the strike of the foliation, which there coincides with the north-south joint system. The valley of Preston Plains, for the most part, follows the strike of the hornblende schist, a relatively soft rock, and conforms in many places to the north-south joint system. The area including Cedar Swamp and the cluster of kames just east of it is walled by relatively resistent gabbro on the north, quartz rock on the east, and alaskite on the south, and lies within an area of soft quartz-biotite schist. Shunock River has developed its course largely along the bands of the soft quartz-biotite schist and is entirely independent of the principal joint systems; but this is of no great significance, as the river for the most part flows through broad drift-filled plains. Broad Brook follows a course about parallel to that of the Shunock. It is not influenced by rocks of different hardness in its upper course, where it is practically parallel to the principal joints. In its lower course it cuts across the strike and contacts of different kinds of rock, away from any marked joint system; however, it probably follows a fault.

It is clear from the above that a principal valley may result from one or several causes, the controlling one of which can be determined only after the relative importance of all have been considered. From the above data, the presence of bands of soft rock between more resistant ones seems to be the most influential factor. Where the rock is of uniform character and well foliated, the valleys follow the strike, but owing to frequent coincidence in the general direction of strike and jointing, the relative importance of the two is obscured. Where the rock is of uniform character and is not extremely foliated strongly developed jointing is the one determining factor; but for large valleys extending over different kinds of rock it is of little or no importance. Faulting, to judge from one poor example, may exert an influence greater than difference in the kinds of rocks, but the degree of its influence obviously depends on the size of the fault and the amount of shattering accompanying it.

\section{MAJOR TRIBUTARY VALIEYS.}

The directions of the major tributary valley axes (see p. 12) show a nearer, though not a close, relation to those of the joint systems. 13338 - Bull. $492-12-4$. 
One well-defined group constituting 60 per cent of the total lies between N. $20^{\circ}$ W. and N. $20^{\circ}$ E., a direction closely conforming with that of the north-south joint system; but (see Pl. I, in pocket) many of the streams follow the direction of strike also. The joints lie a little east of north, and the valley axes, if anything, incline slightly west of north. This divergence is only slight, but may be due to the fact that strike has had as much or more influence in determining the directions of streams than have joints. The absence of valley groups parallel to the strongly developed east-west joint system adds weight to the argument that jointing is of minor importance in the determination of stream courses.

\section{MINOR TRIBUTARY VALLEYS.}

The minor valley axes, however, show distinct relation to jointing. They form three distinct groups (See p. 46.) The largest comprises 40 per cent of the total and runs almost due north; the second, comprising 20 per cent, runs a little north of due east and falls within the limits of the second largest joint system; the third, a small one, lies well within the smallest joint system. The absence of a stream group parallel to one of the northeast-southwest joint systems is the only distinct disagreement between jointing and minor tributaries. Strike may have influenced the direction of many of the north-south streams, but can have had no influence in directing the streams of the other two groups, and these predominate in the northern half of the area, where the strike averages about north-south.

\section{CONCLUSIONS.}

The conclusion drawn from the evidence is that, though jointing was of only slight influence in developing the largest valleys of the region, it was the principal factor in determining the smallest. The evidence regarding intermediate valleys is weak, but agrees with the above statement. This conclusion seems reasonable when it is remembered that the larger valleys generally extend over more than one rock formation, and tend, therefore, to develop along the weaker ones, whereas most of the smaller valleys lie entirely within one formation, and develop, in consequence, along planes of weakness within that formation. The Mystic Valley, though a principal valley, lies wholly within one formation, and therefore follows the principal zone of weakness-a zone of close, or vertical sheet, jointing.

\section{FAULTING.}

\section{CHARACTER AND DISTRIBUTION.}

Faulting in so highly folded and jointed a region would naturally be expected; but, owing doubtless to concealment under glacial drift and also to nearly vertical displacement, little evidence of it was seen in the field. The largest fault actually seen had a throw of less than 2 feet. It occurs on the 300-foot hill west of Amos Lake, has a trend 
N. $70^{\circ} \mathrm{E}$, and a vertical hade. The small slate outcrop north of Lantern Hill also contains a small vertical fault with a horizontal displacement of 1 foot, parallel to the close north-south jointing. This fault is filled by a small quartz veinlet an inch or two wide. Faulting on a small scale parallel to the strike of the schist is revealed at a few places in Preston by the dislocation of transverse aplite stringers. Other slight displacements were found, but are even more insignificant than those mentioned.

Thrust faulting of any magnitude (see p. 26) was not found. Rocks that are extremely plicated show no displacement megascopically beyond the fractures in mineral grains. Microscopic faulting, however, is very common. Shearing and thrust faulting of less than a millimeter throw in feldspars and pyroxenes of the gabbro are common. The abundance of uralitic hornblende in the sheared gabbro, the recrystallized character of the highly schistose rocks, and the granulation of minerals in granite are further evidence of microscopic movements within the rocks.

Study of the outcrop map (Pl. III, in pocket), however, reveals a few pronounced offsets across the strike of certain bands of rock. The largest of these are at Ashwillet and along the valley of Broad Brook where it crosses the western boundary of the gabbro.

\section{ASHWILLET INTRUSION FAULT.}

At Ashwillet the fine-grained quartzitic rock bordering the gabbro is displaced in a northwest-southeast direction ${ }^{\circ}$ for half a mile (Pls. II and III) by a fault which is thought to have accompanied the intrusion of the gabbro. The actual line of displacement is concealed by drift and is located only by the relation of the strike of the quartzitic rock to the adjacent gabbro outcrops. It is true that the strike of the quartzitic rock contains many minor undulations, but there is no sufficient reason for assuming a flexure great enough to unite the different outcrops in this one band of rock, when there is no evidence of a similar flexure in the rocks to the east. The displacement, therefore, could not have been developed during folding.

That it resulted from the gabbro intrusion appears from the fact that it can not be traced in either direction into the adjacent formations. To the southeast a large alaskite sheet crosses its path without suffering displacement; to the northwest, in the gabbro area, no indication of it appears in the topography. If it were formed during the period of jointing, the displacement would represent a heave of half a mile, and should be traceable for a considerable distance both to the southeast and northwest. The fault, therefore, could not have originated subsequent to the folding. The gabbro intrusion produced a domal uplift, but was too irregular in shape to be considered a simple laccolith. During the domal uplift some parts of the cover 
may have been less resistant than others, and between these parts intrusion faulting may have occurred. The term "intrusion fault" was proposed by Ransome, ${ }^{1}$ who has cleurly shown that blocks of the sedimentary rocks in the Globe district, Arizona, were offset by the force of the intruded diabase.

The exact nature of the faulting at Ashwillet can not be determined, as regional metamorphism and subsequent erosion have obscured the evidence. The original movement may be supposed, as in the Globe district, to have raised a block on the northern side of Barnes Hill, thus forming fault lines in two directions. (See Pl. II, in pocket). Subsequent regional folding was sufficient to give the rock on both sides of the fault a vertical dip; and finally erosion, removing the uplifted block, exposed the present surface. Or faulting may have occurred only in one direction, the southeast, owing to higher doming on the northeast than on the southwest side. The final effects of folding and erosion would be the same in either case. Lack of evidence prevents more conclusive inference, but the above hypotheses agree more closely with the facts than any others that have presented themselves. In Plates II and III the actual evidence of displacement is represented by a solid line; the two possible inferences by dotted lines.

\section{BROAD BROOK FAULT.}

At the Broad Brook offset both schist and granite appear to have been displaced and the brook valley to have maintained a generally uniform trend, both across the gabbro and the schist. It is possible that the granite sheets on each side of the valley are separate lenses, which pinch out before reaching the opposite sides; but there is nothing to prove this, and the dimensions both of the sheets and the other rocks (PI. II) and the systematic arrangement by which all on the north side are shifted toward the west are strongly indicative of the faulting of once continuous sheets.

The displacement must have occurred subsequent to the regional metamorphism; that is, after the intrusion of the granite. Comparison of the valley's trend, N. $63^{\circ}$ W., with the joint directions (Pl. VI and fig. 14) shows it to lie within the least distinct of the six systems. The fault, therefore, appears to have no marked connection with the jointing.

MINOR FAULTING.

A few other exposures suggest more or less strongly the possibility of faulting. The small slate outcrop north of Lantern Hill is flanked both to the east and to the west by clusters of large gabbro bowlders (probably broken outcrops), and it very likely represents

1 Ransome, F. L., Geology of the Globe copper district, Ariz.: Prof. Paper U. S. Geol. Survey No. 12, 1903, p. 102 . 
a small fault block that has been moved in the direction of the northsouth joint system. The occurrence on Ayer Hill of several minor summits separated by north-south valleys and the presence in these valleys of a few small outcrops of closely folded schistose hornfels overlying the gabbro are strong indications of step faulting. The quartzite and quartz replacement on the hill west of Swantown Hill strike perpendicularly to the gabbro contact, and may be separated from the latter rock by a north-south fault or by an intrusion fault. Other less pronounced suggestions of faulting occur, but are not sufficiently marked to be represented on the map.

\section{VEINS.}

\section{QUARTZ VEINS.}

The veins of the area, which consist largely or chiefly of quartz, belong to four classes: Interbedded veins due to local segregation, gash veins produced in the same way, pegmatite veins, and quartz veins of pneumatolytic origin, accompanied by replacement of the wall rock. None save the last named deserves more than passing mention.

The interbedded veinlets are plentiful and form small, short lenses in the schists; some contain small crystals of pyrite. The gash veins, which follow joint cracks in numerous directions, are rarely more than an inch or two in width; they are common in the schists and granite, and appear also in the bordering hornblende gabbro, but are practically absent from the central gabbro mass. The pegmatite veins, many of which are rich in quartz, are commonly small and are of only purely scientific interest in showing gradation of pegmatite into pure quartz; in the vicinity of Lantern Hill and at Glasgo they appear to be closely associated with the pneumatolytic quartz veins and replacements. The last named are sufficiently prominent to deserve thorough description, and their structures and origin will be fully discussed later (pp. 135-146).

\section{CHLORITE AND ASBESTOS VEINS IN GABBRO.}

The gabbro is full of blind seams and small fractures cemented by chlorite. Some few of these chlorite veinlets attain a width of an inch or more, and have, owing to their softness, been mistaken for soapstone. ${ }^{1}$ They are noteworthy because their extreme abundance in places renders the collection of well-formed specimens very difficult.

But one small vein of asbestos was noted. It lies in porphyritic gabbro at the steep westerly sloping hill a mile west of Bay Mountain.

1 Some small masses of talc, or true soapstone, have been found in the drift near the northern limit of the main gabbro mass, but never in place. They were possibly derived from the norite phase of the gabbro, which, in thin section, shows more or less alteration to talc. 
Another occurrence, formed by the partial alteration of a basic pegmatite, has been found between the two small swamps at Indian Town. This, when seen, was scarcely exposed, and was completely isolated from any outcrops. The basic pegmatite is similar to pegmatite in the gabbro, and may be a large, buried, glacial bowlder, or possibly a part of an unexposed outlier. The material seen was not sufficiently flexible to be of commercial value.

\section{SPECIAL EROSIONAL FEATURES.}

The general processes and effects of erosion in the area are those which characterize New England as a whole and need no general discussion; but two special features worthy of mention are described below.

\section{PITTED AND WARTY SURFACE OF GABBRO.}

The coarse-grained gabbro in most places presents a pitted or a warty surface. The pitted surface appears where the body of the rock is pyroxene and uralite with poikilitically inclosed feldspars; the pyroxene and uralite are more subject to alteration than the feldspar, and their decomposition around the latter have caused its removal, leaving pits. The warty surface appears in the feldspathic portions of the rock, where the isolated grains and clusters of pyroxene and uralite have weathered and decomposed, leaving in relief the more abundant feldspar areas.

\section{DISSOLUTION HOLES.}

A striking effect of chemical weathering on the basic rocks is manifest in "dissolution holes," which are present in hornfels and hornblende schist as well as in the gabbro. They vary in size from scarcely an inch in diameter to more than a foot in depth and width, but are as a rule small and shallow. The largest found are in the coarse porphyritic gabbro at the west base of Roods Mountain (Pl. VII, $B$ ). Many of these holes clearly result from the accumulation of rain water in slight depressions, either at the intersection of joints or where a small fragment has been plucked by frost action. Where an outcrop lies in a wooded tract, falling leaves and other organic matter accumulate in the holes, generating organic acids which accelerate the dissolution of the rock. As the holes grow deeper, they have a greater capacity for the dissolving agents, and erosion progresses still more rapidly, especially after the holes have become so deep that the water is protected from the evaporating influence of wind and sun. Holes in which water and organic matter are always present, as in those at Roods Mountain, expand downward, owing to the increased rate of dissolution. 
PLATE VII. 


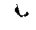

\section{PLATE VII.}

A. Photomicrograph of basic pyroxene hornfels, showing texture and mineral composition. The three conspicuous minerals are labradorite, bronzite, and ilmenite. Magnified 40 diameters. Without crossed nicols. Section 11.

$B$. Dissolution holes in porphyritic gabbro, due to corrosion by water and products of decaying vegetation.

56 

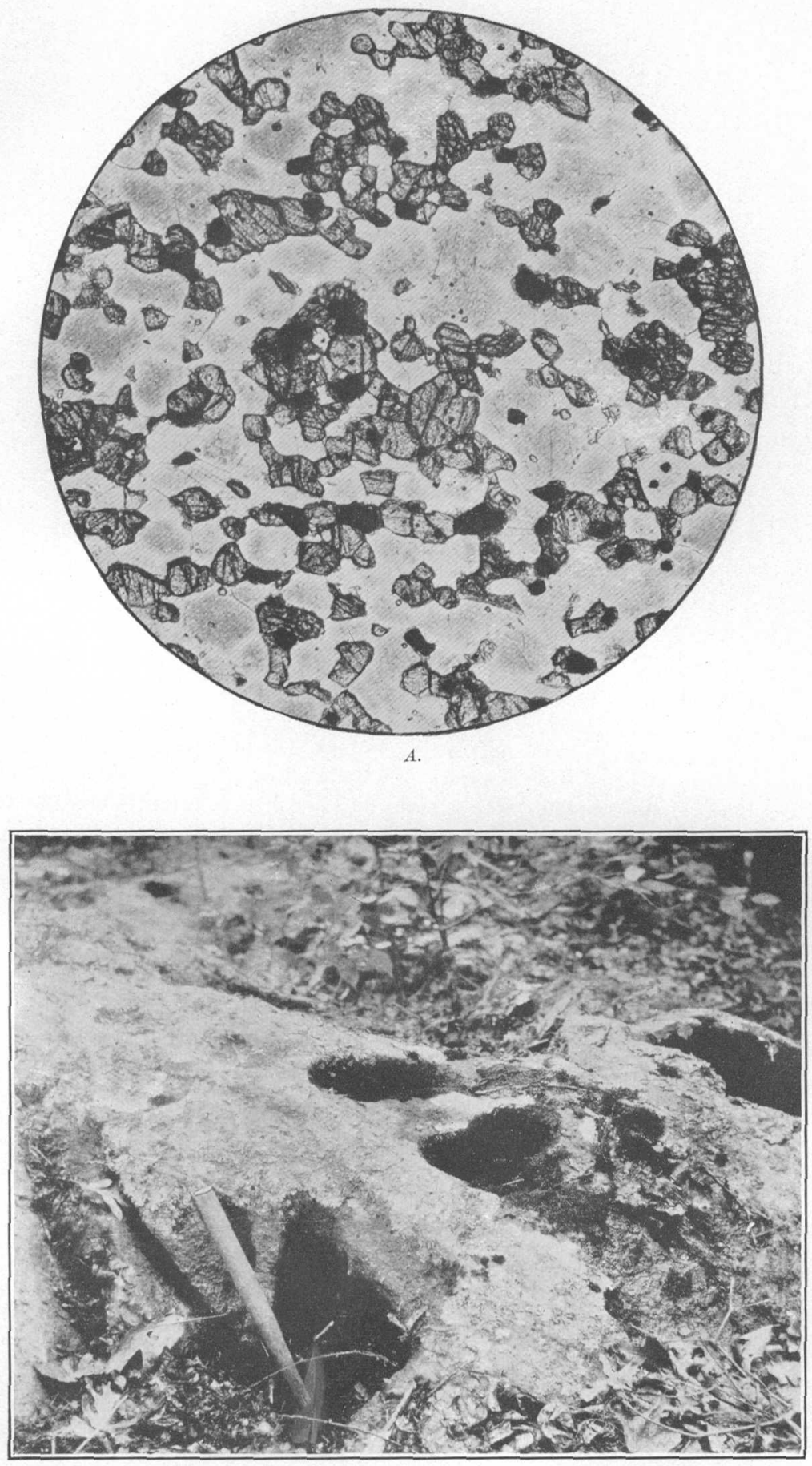


\section{HISTORICAL GEOLOGY.}

The earliest rocks of which any definite record remains are those of sedimentary origin. The quartz-biotite schist, with the quartzite in its lower part, is the lowest distinct formation. This rock in its upper portion becomes somewhat finer grained and passes into the fine-grained quartzitic rock at Ashwillet, and this in turn grades into hornblende schist. These rocks, all but the last named, denote the continual deposition of more or less pure quartz sand; the hornblende schist is regarded as originally a basaltic tuff, marking a period of volcanic activity during sedimentation. This rock, as far as obscure data show, is filled in its upper portion along the western edge of the area with interbeds of kinzigite, whose significance is not fully understood. Later discussion (pp. 74-76) suggests that they may be the recrystallized product of altered basaltic tuff. East of Preston the hornblende schist passes upward into feldspathic quartz-biotite schist, which is provisionally regarded as the youngest existing sedimentary rock. Its relations, however, to the kinzigite have not been satisfactorily determined. It marks a cessation of volcanic activity and a resumption of the deposition of land-eroded material. The abundance of feldspar, giving the original rock an arkose character, suggests that mechanical erosion prevailed over chemical more than it did during the deposition of the earlier quartzose strata. The dolomite and lime-magnesia silicate interbeds or lenses are chiefly limited to the vicinity of the boundary between the hornblende schist and the overlying feldspathic quartz schist. Their exposures are so few, so small, and so scattered that ne more definite correlation seems justifiable. They mark slight interruptions in the deposition of volcanic and of land-eroded material.

After the sediments had been buried to a considerable depth by continued deposition, there came the gabbro intrusion in the form of an immense sill-like mass, doming and faulting the rock above it. Several smaller outlying sills accompanied the main one. That the depth of intrusion was considerable is inferred from the coarse texture of the gabbro and from the fact that it remained molten long enough to undergo some differentiation.

Some time after the gabbro had solidified and cooled the whole region was subjected to intense folding and granite intrusion in the zone of flowage. Following the period of folding, but not before the cessation of all granitic intrusion, the region suffered jointing with minor faulting. This jointing in a few places gave access to the pneumatolytic portion of the granitic magma, which formed pegmatite and quartz deposits at Lantern Hill and other less conspicuous places. 
Long-continued denudation, which developed the Cretaceous peneplain, followed, succeeded by uplift and renewed denudation, which developed a maturely dissected topography. The chief factor in developing the present bedrock topography was the relative hardness of the different rocks, supplemented to some extent by jointing.

The glacial epoch ensued, depositing its mantle of till and rounding the topography generally. Its retreating stages were marked by the formation of several temporary lakes, which occupied the present flat valleys, and by some modifications of stream courses.

Geologic activity since glacial times has been very slight. It has sufficed to disintegrate the more exposed portions of highly foliated rock, obliterating glacial striations and developing "dissolution holes" in a few places. Further than this its effects are practically nil.

\section{PETROGRAPHY.}

\section{METAMORPHIC SEDIMENTARY ROCKS.}

Although the metamorphosed sedimentaries all belong to one complex and grade into one another, several varieties (see p. 16) are so distinct as to deserve separate petrographic descriptions.

\section{QUARTZITE.}

Megascopic characters.-The quartzite is massive and uniformly fine grained and is commonly yellowish brown, though in some places purplish. The color, as seen by the aid of a lens, is due to small, evenly distributed grains of pale-brown mica inclosed in the quartz and spread in the thinnest of films along the foliation planes. These planes invariably show fine slickensides. Here and there a dark or rusty spot suggests the former presence of pyrite. A few bleached spots with an inner border of ferric oxide and an outer chloritic rim, similar to those seen in the purple slates of Vermont, are seen.

Microscopic characters.-The microscope reveals, as principal minerals in the typical rock, quartz (90 per cent or over), brown mica ( 8 per cent of less), and magnetite ( 1 or 2 per cent). High power shows scarce granules of titanite, zircon, epidote and zoisite, feldspar, muscovite, and a few broken needles of sillimanite.

The quartz consists of fine, closely interlocking grains with undulatory extinction. Black, indeterminable inclusions of rounded or rodlike form appear in many of the quartz grains, but never in the shape of an original quartz grain, previous to secondary enlargement. Such, however, is not to be expected in a quartzite formed under intense pressure, as the outlines of original grains must have been completely destroyed by shearing and mashing accompanied by recrystallization. 
The mica occurs as thin scales, evenly distributed and weakly pleochroic. Many scales are so thin as to be completely inclosed by quartz even in thin section. Some scales show alteration to, or intergrowth with(?), typical muscovite, others to chlorite, others to indeterminate brightly polarizing aggregates resembling carbonate. Magnetite occurs in small, irregular grains and is practically confined to certain bands, of which it constitutes about 10 per cent.

Variations and similar rock from other horizons.-A specimen from the upper portion of the occurrence at Pendleton Hill shows, in thin section, 15 to 20 per cent each of plagioclase and diopside and a few grains of actinolite. The plagioclase occurs in irregular grains of different sizes, the largest being 2 to 4 millimeter long. Measurements of extinction angles in sections normal to albite twinning and also on 010 sections prove it to be chiefly labradorite, near $A b_{1} A_{n}$. The diopside and actinolite occur in hypautomorphic grains 1 to 2 millimeters long and in fine aggregates. They are distributed among quartz grains, and also impregnate the labradorite. The grains mostly lie in clearly defined rows, some of which pass through large plagioclase grains. Several are partly altered to zoisite or stained with limonite.

The quartzitic rock at Barnes Hill is similar in composition to that at Pendleton Hill, but is very fine grained and shows no impregnation of labradorite by the diopside present. The amount of mica varies from almost nothing to 15 per cent. Hornblende is present in some of the more western outcrops.

The presence of labradorite and diopside at Barnes Hill as well as at Pendleton Hill favors the supposition that the former occurrence is a part of the quartzite formation; but structural evidence places it at a higher horizon. (See p. 17.) The labradorite and hornblende serve as connecting links between this quartzitic rock and the hornblende schist.

\section{QUARTZ-BIOTITE SCHIST.}

Megascopic characters.-The typical rock is light to dark gray in color, of medium and uniform grain, and has a distinctly schistose structure. Specimens, at first glance, resemble gray gneissoid granite, but most of them on close examination are seen to be deficient in feldspar. Single outcrops, taken by themselves, may give no clue as to the original character of the rock, but field evidence as a whole and microscopic study lead to the conclusion that the original rock was sedimentary.

Microscopic characters.-The schistose structure is distinct but in general not extremely developed, owing to the low percentage of mica. The principal minerals revealed by the microscope are quartz (65-70 per cent), feldspars (15-20 per cent), and biotite (12-15 per cent); other minerals, insignificant in amount, are muscovite, titan- 
ite, magnetite, limonite, apatite, zircon, garnet, and, in one specimen, allanite.

Quartz occurs in elongate grains with undulatory extinction. The grains are, as a whole, uniform in shape and size and free from granulation; but here and there an unusually large grain shows partial granulation. Feldspar, in smaller, more irregular grains than the quartz, includes plagioclase $\left(A b_{3} A n_{1}\right.$ to $\left.A b_{1} A n_{1}\right)$, a little microcline, and possibly some orthoclase. All determinations of unstriated grains prove them to be plagioclase, but it is possible that a few of orthoclase have been overlooked. Unstriated feldspar is readily distinguished from quartz in plane light by its partial kaolinization. Between crossed nicols it shows partial alteration to sericite as well as to kaolin.

Biotite forms wavy rows of short, narrow tablets between the quartz-feldspar layers. Several individuals are partly altered to chlorite or to muscovite.

Magnetite and limonite are scarce. The magnetite is usually inclosed by a fringe of biotite or is closely associated with titanite; the limonite surrounds certain magnetite grains, and fills the cleavage cracks of a few biotite flakes. Titanite forms automorphic grains along the foliation planes. Many of the grains show the polysynthetic twinning characteristic of titanite in the crystalline schists. Apatite and zircon occur in small to minute grains, the larger of which are rounded at the corners; the smaller show crystalline faces. Garnets are very scarce, occurring in small rounded grains.

Allanite.-Allanite was detected in but one section, in which three half-decomposed grains were found bunched together. This mineral, owing to its ready decomposition by weathering, is usually supposed to be limited to rocks of igneous origin, and is used as a means of determining the igneous origin of a gneiss or schist. It has not, so far as the writer can ascertain, been mentioned as occurring in sedimentary rocks; but it is possible that, very rarely, a crystal may be preserved in a small pebble of igneous rock deposited in a coarse sandstone or arkose. The relation of the allanite in this instance to the other minerals gives no evidence of its having been included in a pebble. The grains around it are of uniform size and display no flaser structure indicative of a mashed pebble; but the general absence of flaser structure throughout the section permits the inference that the rock is so thoroughly recrystallized that a small pebble may have been entirely obliterated.

Variations.-Some thin sections show the following variations from the type: Very light gray, consisting almost wholly of coarse quartz grains; gray, consisting mostly of quartz with more or less feldspar and with lime-magnesia silicates instead of biotite; dark gray, with about 60 per cent of quartz, 40 per cent of biotite, and almost no 
feldspar; gray, composed of quartz and feldspar (chiefly plagioclase) in about equal amount, and common green hornblende instead of biotite; rather dark gray, with a mineral composition like that of a quartz diorite. The feldspathic schist extending through Preston corresponds, as a whole, to the last-named variety. From these variations it is evident that the original rock was in general a more or less feldspathic sandstone or arkose high in plagioclase, with here and there quartzose and calcareous variations.

Epidote gneiss.-Contact action of the large porphyritic granite sill on the quartz-biotite schist at Billings Lake resulted in thorough injection and partial epidotization of the latter (p. 43). The degree of injection varies from slight to the extreme case where the thinnest folia of epidotized schist are separated by aplite stringers, and the resulting composite rock may be called an epidote gneiss.

Under the microscope (Pl. V, $A$, p. 42) the epidote gneiss is seen to consist of bands of fine-grained granitic material very rich in quartz, separated by bands, or lenses, of epidotic material. The latter consists principally of a varying amount of epidote (50 to 75 per cent), fine aggregates of sericite and quartz, and flakes of biotite and muscovite. Small wedge-shaped titanite crystals are scattered through the band. Scattered grains of hornblende, garnet, apatite, and feldspar occur, the latter partly sericitized.

The epidote occurs mostly in distinct crystal grains, a millimeter or less in length. Many grains are adjacent to or partly surrounded by biotite and are automorphic. They are also closely associated with sericite areas. The sericite areas suggest a complete replacement of feldspar. Wherever feldspar was noted in the epidotic areas it was close to a quartzose stringer and seemed to be an impregnation from the stringer rather than an original constituent of the epidotic rock. No direct evidence remains as to the identity of the original feldspar, but from the abundance of epidote, it was probably plagioclase fairly high in lime.

Where muscovite flakes are prominent, sericite areas are inconspicuous. The micas both tend to inclose epidote grains. The biotite is, with rare exceptions, fresh, and has strong absorption. Hornblende is rare and forms small intergrowths with biotite.

Where the alternating bands are well defined, the boundaries are not perfectly sharp. The slight impregnation of the epidote rock by feldspar has already been noted. Quartz grains occur in the same manner. Bands of epidote rock are seen to thin into more or less definite rows of biotite and epidote. Some of these rows are not connected within the area of the thin section to any distinct band, and it is difficult to tell whether they are mostly original in the quartzose bands or are the result of a mechanical assimilation. Where epidote is absent there is no evidence that the biotite is not original; where epidote is 
present, it seems probable that mechanical assimilation has taken place. (See Pl. V, p. 42.)

The granitic bands consist mostly of quartz, somewhat granulated, and showing undulatory extinction. The percentage of quartz ranges from 100 downward, but is never lower than 60 . The feldspars are next in importance, comprising about equal amounts of microcline and acidic plagioclase. They show a moderate amount of kaolinization, and the plagioclase in some places is impregnated with calcite. Feldspars that may have crystalized as impregnations in the epidote rock show partial sericitization. Biotite, hornblende, titanite, and rarely magnetite, occur. The condition of the first two, whether original or included, has already been noted. They are practically free from alteration. Titanite also may be partly original in the granite band and partly included. Epidote grains are also present, but are thought to be, with one or two possible exceptions, inclusions.

No tourmaline or other minerals characteristic of pneumatolytic action were seen, but the highly quartzose character of the granitic material is evidence that the invading solution must have been of a highly aqueous character. The sericite and epidote are further evidence of the action of aqueous solutions at very high temperature, if not above the critical temperature. ${ }^{1}$ The abundance of epidote points to the calcareous nature of the original rock. Water was the chief mineralizer and may have carried sufficient silica and alumina to have formed the epidote; but from the presence of impure plagioclase grains and of lime silicate layers elsewhere in the schist, it is equally possible that all the constituents save water were present in the rock previous to the intrusion of the granite.

This contact zone, though of much less extent, is similar to that noted by Duparc and Mrazec in their study of the contact between protogine and schist on Mont Blanc. ${ }^{2}$ The only essential difference is that apophyses cutting across the foliation are not uncommon at Mont Blanc and are practically absent at Billings Lake.

HORNBLENDE SCHIST. ${ }^{3}$

The petrography of the hornblende schist is similar to that of the amphibolite sheets associated with the gabbro.

Megascopic characters.-The typical rock is greenish black to black, fine to coarse grained, and highly schistose. The only megascopic minerals are hornblende (over 50 per cent) and irregular, glassy grains which closely resemble quartz, save where glistening cleavage planes prove them to be feldspar. Quartz appears to predominate over

1 Lindgren, W., The relation of ore deposition to physical conditions: Econ. Geology, vol. 2, 1907, p. 112.

2 Duparc, L., and Mrazec, L., Recherohes géologiques et pétrographiques sur le massif du Mont-Blanc, Paris, 1898.

3 For convenience "hornblende schist" is used to designate the hornblendic rocks interstratified with the sedimentaries; "amphibolite" to designate the smaller intrusive sheets associated with the gabbro. 
feldspar; but the microscope proves primary quartz to be practically absent. Alteration is marked by veinlets and small patches of epidote.

Microscopic characters.-The schistose structure is strongly marked by alternating bands or lenses of hornblende and labradorite. The minerals seen under the microscope are hornblende (50 per cent), labradorite (45 per cent), quartz and epidote (with zoisite) each about 2 or 3 per cent, and small, unevenly distributed quantities of titanite, ilmenite (or magnetite), and rutile. The hornblende is the common green variety, in grains averaging 1 millimeter in length. The labradorite $\left(A b_{1} A n_{1}\right)$ occurs in aggregates of anhedrons, largely unstriated, and averaging less than 1 millimeter in diameter. Quartz is limited to occasional veinlets along the schistosity. Epidote and zoisite occur in the feldspar areas, or between hornblende and feldspar. Black iron minerals are in many places conspicuously absent, although some sections contain as much as 1 or 2 per cent of them. The presence of titanite and rutile where the iron minerals are absent suggests that the latter broke down during recrystallization, the iron entering into the strongly pleochroic hornblende, and the titanium into rutile or titanite. This inference, of course, supposes the original mineral grains to have been largely ilmenite.

Variations.-One thin section shows the hornblende bordered by brown biotite, the latter with excellent sagenite inclusions. Another from a specimen taken near an area of feldspathic quartz schist shows plagioclase and quartz over 50 per cent, the latter averaging about 15 per cent, and original biotite predominating over the hornblende (about $1.5: 1$ ). Since much of the feldspar is almost, or quite, free from twinning striæ, it is possible that a few alkalic feldspars are present, though none were identified. The presence of alkalic feldspar, even in small amounts, would completely establish the character of the section as a gradation between the hornblende schist and the overlying feldspathic schist.

Variations in degree of alteration are marked by the relative amount of epidote and zoisite; more complete alteration is marked by the additional presence of calcite and chlorite. Besides these variations in composition, the two textural variations, basic slate and hornfels, deserve special consideration.

\section{BASIC SLATE.}

Megascopic characters.-Basic slate is black in color and possesses a moderately developed slaty cleavage, but has a somewhat higher specific gravity (2.833) than ordinary black roofing slate. The cleavage is parallel to the bedding, which is revealed by thin bands of quartzite and of lime-magnesia silicates, each about an inch wide, and by faint banding. The generally aphanitic texture is, in some 
laminæ, faintly mottled by small, rounded feldspar grains, each oneeighth inch or less in diameter, and comprising not more than 5 per cent of the rock. They are similar to the pseudophenocrysts in the kinzigite. Pyrite, in minute grains, is very conspicuous along certain laminæ, but constitutes only an insignificant portion of the whole rock.

Microscopic characters.-The laminated structure is very marked and is characterized by miniature plications and thrust faulting. The pseudoporphyritic texture is far more pronounced than appeared to the naked eye. The minerals seen in thin section are plagioclase (probably over 50 per cent), hornblende (less than 40 per cent), with quartz and pyrite in minor varying amounts. The secondary minerals are sericite, chlorite, epidote, and ferric oxide. They are included in the above percentages.

The pseudophenocrysts, most of them of plagioclase and a few of hornblende and quartz, are of a generally rounded to oval outline, and are wrapped around by the groundmass similar to garnets in mica schist. They vary in diameter from 2 or 3 millimeters down to minute granules of the groundmass. It is therefore difficult to estimate their percentage, but the more prominent ones may amount to as much as 40 per cent of the rock. The much smaller percentage given under the megascopic characters is due partly to the generally small size of the phenocrysts and to their envelopment in the dark groundmass.

The plagioclase has the optical properties of labradorite. Twinning striæ, as in the labradorite of the hornblende schist, are in most cases absent or very poorly developed, and grains suitable for measurement of any kind are few. The labradorite is most readily distinguished from quartz by its minute inclusions of sericite and, in some specimens, by its cleavage; where both of these characters are absent, it may be identified by its biaxial interference figure. The rounded, anhedral appearance of the larger grains suggest that they may be the original pebbles of a fine arkose which, owing to the softness of the matrix, were rolled without mashing or losing their original form; but (see p. 72) feldspars developed in metamorphic rocks are not uncommonly characterized by lack of crystalline outline and of albite twinning. It is therefore thought more probable that these grains were developed during metamorphism.

The hornblende is the common variety, and its grains show no approach to crystal outline. The few quartz grains that are of noteworthy size resemble the feldspar in form.

The minerals of the groundmass are determinable only under the highest power. They are the same as the phenocrysts. The hornblende is in minute fibers, largely altered to chlorite, scattered among rounded granules of feldspar and quartz, The relative amounts of 
the two latter minerals can not be determined owing to the minute size of the granules. Numerous black streaks and grains of ferric oxide have resulted from the oxidation of minute pyrite crystals. Veinlets and granules of epidote are also present.

The interbedded quartzite band is extremely fine gramed and, like the slate, shows microscopic thrust faulting. It consists almost wholly of quartz, with a few hornblende fibers and epidote veinlets.

\section{BASIC HORNFELS.}

The hornfels is of two varieties-hornblendic and pyroxenic.

HORNBLENDIC VARIETY.

Megascopic characters.-The hornblendic hornfels is a greenish-black, dense, almost aphanitic rock, cut in all directions by epidote veinlets and by quartz-feldspar stringers from the gabbro. On some outcrops where there is evidence of original stratification, as at Prentice Mountain, the stringers from the gabbro tend to follow the stratification planes. In some specimens, coarser grained than the average, small fibers of uralitic hornblende can be detected.

Microscopic characters.-The microscope reveals an excellent hornfels texture. The essential minerals are hornblende and labradorite, the same as in the hornblende schist. The hornblende possesses the same pleochroism as in the hornblende schist, but has the uralitic character; the feldspar has the same composition $\left(A b_{1} A n_{1}\right)$. Black metallic grains are uniformly distributed, and rutile and titanite are practically absent. One thin section shows brown biotite bordering hornblende-a variation noted in the hornblende schist. Epidote and occasionally scapolite are the chief alteration products.

The principal difference between the hornblendic hornstone and the hornblende schist is in the texture.

\section{PYROXENIC VARIETY.}

The pyroxenic variety of hornstone is of exceptional occurrence. One outcrop is on the summit of the 400 -foot hill north of Broad Brook, in the northwestern part of the gabbro area. It forms a long roche moutonnee, with radiating epidote veinlets and quartz-feldspar stringers which characterize the other hornfels inclusions. Its actual contact is concealed by drift.

Megascopic characters. - The pyroxenic variety is nearly black in color, with a purplish tint, and is a little coarser grained than typical hornblendic variety. The hornfels texture can be detected with the hand lens.

Microscopic characters.-The minerals seen in thin section (Pl. VII, $A$, p. 56) are plagioclase (55 per cent), pyroxene (35 to 40 per cent), ilmenite (10 per cent or less), a few minute prisms of apatite, and small quantities of secondary uralite, calcite, chlorite, feerric oxide, $13338^{\circ}-$ Bull. $492-12-5$ 
and kaolin (total only 1 or 2 per cent). The hornfels texture is better developed than in the hornblendic variety.

The plagioclase is labradorite in irregular, equal-sized grains, less than 1 millimeter in diameter, all slightly clouded by kaolin. The pyroxene occurs mostly in small drop-like grains, 0.5 millimeter in diameter, nearly all possessing the properties of bronzite-parallel extinction, optically positive and weakly pleochroic ( $\mathfrak{a}=$ light brown or buff, $\mathfrak{b}=$ very pale yellowish, $\mathfrak{f}=$ very pale greenish; sections in the plane of $\mathbf{b}$ and $\mathfrak{r}$ are practically nonpleochroic). A few grains give more or less inclined extinction (10 per cent or less) but otherwise show the characters of bronzite. As clino-enstatite is known, this may be considered clino-bronzite.

A few grains of diopside are also present, recognizable by their higher birefringence and extinction angles between $30^{\circ}$ and $37^{\circ}$. They are considerably altered to calcite and ferric oxide, and are surrounded by a chloritic fringe. The black iron mineral is uniformly scattered throughout the slide in small irregular grains, some included in and some interpenetrating with the pyroxene. The uralite is confined to a hairlike veinlet along a miniature shear zone.

Other thin sections from hornfels inclusions nearer to the edge of the gabbro mass prove conclusively that the hornblendic variety is secondary after the pyroxenic variety. The pyroxene remnants are few, but are similar to the bronzite described above and show partial conversion to uralite along their borders. The distribution of these several phases of the hornfels leads to the conclusion that they and the hornblende schist are parts of the same formation. The pyroxenic variety is limited to inclusions fully protected by the resistant gabbro from compression; the hornblendic variety was only partly protected, suffering recrystallization of the pyroxene but retaining its hornfels texture; the hornblende schist, entirely unprotected, suffered not only recrystallization of the pyroxene but also destruction of the hornfels texture (where sufficiently near the gabbro), the fibrous uralite becoming compact green hornblende and the iron mineral largely disappearing. This conclusion, based wholly upon microscope study, is quite in accord with the field evidence previously given.

\section{ORIGIN OF THE HORNBLENDE SCHIST.}

The mineral composition of the hornblende schist and its subvarieties suggest that it was originally an igneous rock, but the field evidence (see p. 19) points to a sedimentary origin. The three possible origins that suggest themselves for such a rock are (1) a flow of basalt, (2) an arkose derived from a basalt or gabbro, and (3) a basaltic tuff.

The gradational phases between the hornblende schist and the adjacent schists, together with the interlaminated quartzite and 
lime-magnesia silicate bands noted in the basic slate, do not favor the conclusion that the original rock was a basalt flow. It may be argued that there were perhaps several flows separated by thin bands of different rock; but the contacts of the basalt would be fairly sharp and its texture uniform. The gradations observed suggest that the rock was more probably of sedimentary origin. The question may be raised as to whether a basalt would be converted into a hornfels by the intrusion of a magma of similar composition. If the basalt were microcrystalline it might not be affected; if it were partly or wholly glassy, it might undergo crystallization and develop a hornfels texture owing to simultaneous growth of the different minerals.

If the original rock were an arkose, it must have been derived by the disintegration from a basalt or gabbro without much decomposition. It is generally understood that the erosion of basic rocks is accompanied by considerable decomposition of the black silicates and to a less extent of the plagioclase, the lime, magnesia, and alkalies passing into solution, leaving an excess of kaolin and ferric oxide. If such partly decomposed material were deposited to form basic arkose, it seems probable that the kaolin and ferric oxide would, during metamorphism, have recrystallized as garnets or staurolites and mica or some anhydrous aluminum silicate. A few very small garnets have been noted in thin section, but they are by no means a marked character of the rock. It is generally known that plagioclase on weathering loses its lime before soda and that the recrystallization of a partly decomposed plagioclase would produce a more acidic variety (for example, albite in saussurite gabbro); but in the present instance the feldspar is the typical labradorite of basic eruptive rocks. While, therefore, it is possible that the rock may have been an arkose derived by the disintegration, with only slight decomposition, of a gabbro or basalt, such an origin must be considered exceptional.

In a basaltic tuff, fine grains or dust of fresh plagioclase and pyroxene are deposited along with more or less material derived from mechanical erosion. Gradational contacts are to be expected, and thin, interlaminated beds of quartzose or calcareous material may form between intermittent eruptions. Any alteration of the tuff material would be due to infiltrating ground water and would probably be confined to certain strata where the water should find favorable channels. The conversion of a basaltic tuff into basic hornfels by the heat of an intrusion seems quite as possible as the conversion of siliceous muds into typical hornfels. It would involve the recrystallizing of porous material into a dense, impervious mass, accompanied by shrinkage. The evidence of shrinkage is well preserved by the epidote veinlets (p. 40). It therefore seems most probable that the hornblende schist was originally a basaltic tuff. 
BLACK PSEUDOPORPHYRITIC SCHIST (KINZIGITE).

The black pseudoporphyritic schist, which occurs mostly in Preston along the western edge of the area mapped, evidently belongs to the group of German kinzigites, and also has some characters in common with the Hoosac (albite) schist of Hoosac Mountain, Mass.

Literature.-The name "kinzigite" was given by Fischer ${ }^{1}$ in 1860 to an interbed consisting essentially of mica, garnet, and oligoclase, in a series of sedimentary gneisses. The following year ${ }^{2}$ he gave a detailed description of the rock and briefly mentioned other similar occurrences in Europe. He noted that the feldspar in some cases showed excellent albite twinning and in others showed none. In 1884, Weber ${ }^{3}$ redescribed the original occurrence. He mentions the oligoclase as occurring to a considerable extent as porphyritic crystals up to 1 centimeter in length. He also found the rock to contain graphite. In 1882 Sandberger ${ }^{4}$ made brief mention of a graphite and garnet bearing gneiss at Gadernheim, in the Odenwald, which he showed to belong to the kinzigite group. Brief reviews of the occurrences of kinzigite and of the corresponding literature are given by Zirkel ${ }^{5}$ and Rosenbusch. ${ }^{6}$ Rosenbusch defines kinzigite as a paragneiss of varying composition, rich in garnet and poor in quartz, with a high content of mica, mostly dark, with oligoclase and rarely microcline as the predominating feldspar, and with graphite, cordierite, sillimanite, and spinel as accessories.

Megascopic characters.-The rock of the Preston area (Pl. VIII, B) differs in texture from that of specimens of the German types studied by the writer much as a granite porphyry differs from a granite. The German specimens are grayish medium-grained rocks composed essentially of feldspar and garnet wrapped.around by rather inconspicuous biotite, and the rock of the Preston area is black and appears in the hand specimen to be made up almost entirely of a dense, schistose mat of biotite containing numerous small garnet crystals 2 millimeters or less in diameter, and plagioclase crystals mostly less than 0.5 centimeter long, though some are considerably longer.

The percentage of plagioclase varies; in occasional layers it occurs in large crystals, 1 to nearly 3 centimeters long, constituting almost the entire layer; in general it forms small crystals uniformly distributed but largely concealed, as is the garnet, by the enveloping mica. The percentages, therefore, of feldspar and garnet will be estimated only from thin section. Several of the plagioclases show an approach to crystal outlines, though most are well rounded. They

1 Fischer, H., Neues Jahrb., 1860, p. 796.

2 Idem, 1861, p. 641.

3 Weber, E., Min. pet. Mitt., vol. 6, 1884, p. 25.

4 Sandberger, H., Neues Jahrb., etc., vol. 1, 1882, p. 158.

5 Zirkel, F., Lehrbuch der Petrographie, vol. 3, 1894, p. 209.

o Rosenbusch, H. von, Elemente der Gesteinslehre, 1901, p. 496. 
PLATE VIII. 


\section{PLATE VIII.}

$A$. Photomicrograph of pseudoporphyritic kinzigite. The large white areas are albite-oligoclase, the dark areas garnets. Both are of metamorphic origin. The edges of the albite-oligoclase grains indicate growth by assimilation of small granules from the groundmass. The groundmass is a fine-grained aggregate of biotite, albite-oligoclase, quartz, and ilmenite. Magnified 40 diameters. Nicols crossed. Section 10.

$B$. Specimen of pseudoporphyritic kinzigite. The white crystals are albite-oligoclase of metamorphic origin; the rather inconspicuous black spots are small garnets. The groundmass is a dense schistose mat of biotite, with schistosity parallel to the broad surface of the specimen. 


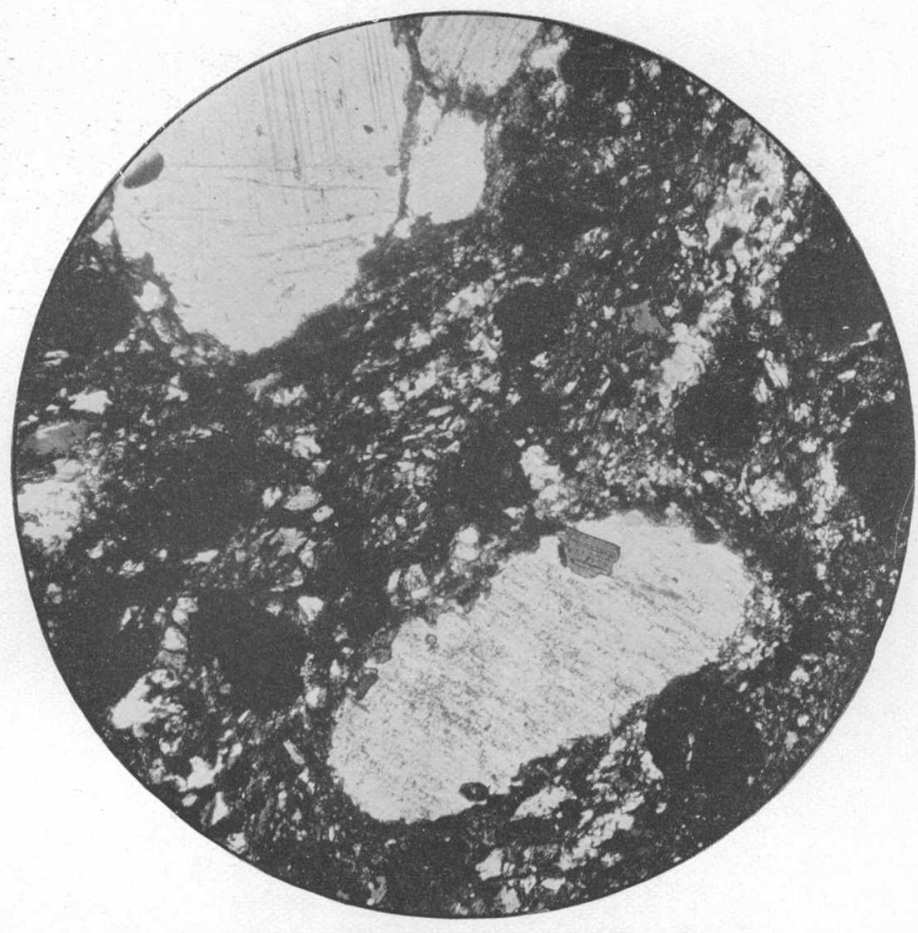

A.

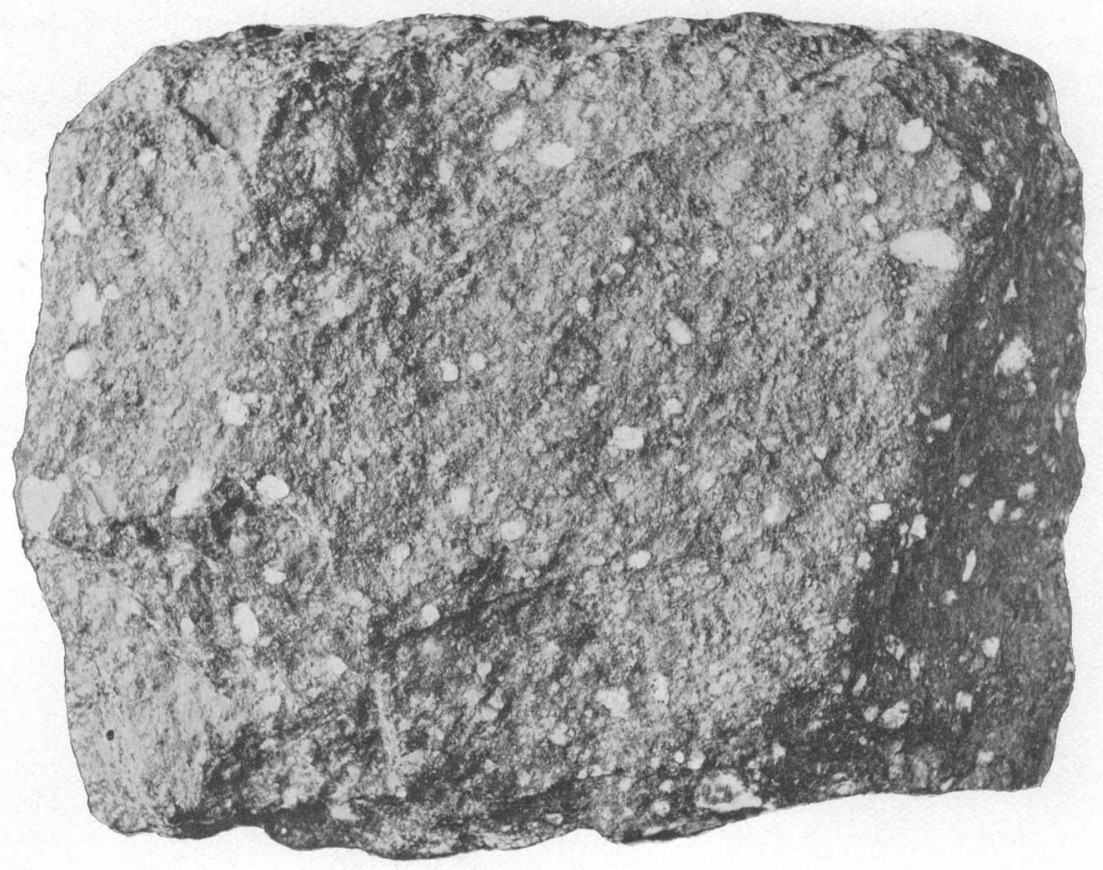

$B$. 
have in general a transparent, almost vitreous, luster. Some show excellent albite twinning. The garnet, also, is especially abundant along certain laminæ.

The mica mat is usually somewhat bleached on the surface. Some outcrops are weathered to a yellowish brown or rusty color.

Microscopic characters.-The microscopic texture (PI. VIII, $A$ ) is the same as the megascopic. The mineral composition of the typical rock, as seen in thin section, comprises plagioclase phenocrysts (30 to 35 per cent), garnet phenocrysts ( 15 to 20 per cent), and a groundmass consisting largely of biotite with subordinate amounts of plagioclase, quartz, ilmenite, apatite, and zircon. Secondary minerals are chlorite, epidote, zoisite, muscovite, culcite, and more or less kaolin. No other accessories (graphite, cordierite, sillimanite, etc.) seen in the German types were found in thin section, though a small lenticular interbed of sillimanite schist (p.20) was noted in the field.

The plagioclase occurs mostly in rounded or elliptical grains varying in diameter from 3 millimeters down to minute granules in the groundmass. Partial crystal outlines are very scarce. Carlsbad twinning appears in several specimens, but albite twinning is absent or only slightly developed in many grains. Opportunities to measure extinction angles, either of albite twins or of cleavage on 010 sections, were very few in the sections studied. Most of the measurements taken identified the mineral as oligoclase, between $A b_{4} A n_{1}$ and $A b_{3} A n_{1}$. A few grains gave values nearer those of albite, and in one section the predominating feldspar was andesine $\left(\mathrm{Ab}_{5} \mathrm{An}_{3}\right)$. Grains resembling soda orthoclase are very rare. Some grains, with maximum birefringence but with no trace of twinning and wholly enveloped by biotite, are strikingly like quartz, but are identified by their biaxial figures. The grains as a whole are free from granulation, and the edges of many fade into the surrounding biotite and even include small flakes of it without disturbing their orientations. These relations, which are similar to those of the garnet, lead to the conclusion that the plagioclase phenocrysts were developed during metamorphism by accretion, which forced the biotite layers apart and even slightly impregnated them. The compound shapes of certain of the larger individuals suggest that they grew at the expense of smaller crystals around them.

The plagioclase of the kinzigite agrees in many respects with the albite in the Hoosac schist of Hoosac Mountain, Mass., described by Wolff. ${ }^{1}$ In that rock, also, porphyritic plagioclase is common and polysynthetic twinning rare. The grains have a rounded, lenticular, or flat shape, with inclusions of the regularly curving bands of the enveloping groundmass, thus proving that the albite "evidently 
crystallized contemporaneously with the other minerals of the rock." Wolff, in another publication, ${ }^{1}$ says of the albite schist:

It is a peculiarity of the dynamic metamorphism of both sediments and eruptive rocks that the new feldspar is sometimes a pure albite or soda-lime feldspar near to albite in the series, and that the habitus is unlike that of similar feldspars in eruptive rocks, inasmuch as the crystal form is imperfect and the crystals untwinned, even under the microscope, or in simple twins, unlike the multiple-twinned albite of eruptive rocks.

The garnet grains are mostly 1 millimeter or less in diameter, though a few are considerably larger. They are rounded or dodecahedral in outline, and show characteristic partings normal to the schistosity. The partings are mostly lined by a very slight fringe of chlorite.

The biotite occurs mostly in masses of short tablets, less than 1 millimeter in length, surrounding the feldspar and garnet, and in a very few larger crystals inclosed by feldspar. It is strongly pleochroic, from rather light brown to almost black, and is probably near lepidomelane in composition. The quartz is present mostly as fine, irregular grains without marked undulatory extinction. A few granular lenses are present, as though large grains had been crushed; there the grains show undulatory extinction. The black iron mineral is closely associated with and mostly surrounded by the biotite. Judging from the amount of $\mathrm{TiO}_{2}$ in the chemical analysis it is largely ilmenite. Apatite and zircon form minute crystals, mostly inclosed in the larger minerals.

The secondary minerals occurring in only a few sections present their usual features. The chlorite is excellently developed after biotite and less commonly after garnet. Muscovite has resulted from alteration of feldspar and to a slight degree of biotite. Both chlorite and muscovite characterize specimens that have suffered an unusual degree of mashing, by which the feldspar phenocrsyts became slightly granulated. Epidote and zoisite, in irregular grains, accompany the chlorite in a few specimens. In one section they form distinct crystals, and bear the same relation to the groundmass as do garnet and feldspar. Calcite in small amount may accompany feldspar and biotite in the more crushed specimens. Kaolin is only slightly developed in the feldspars.

- Chemical composition.-The chemical analysis of the kinzigite of the Preston area, together with four analyses of typical German occurrences, is given in the following table: 
Analyses of kinzigite.

\begin{tabular}{|c|c|c|c|c|c|}
\hline . & 1 & 2 & 3 & 4 & 5 \\
\hline \multirow[t]{2}{*}{ 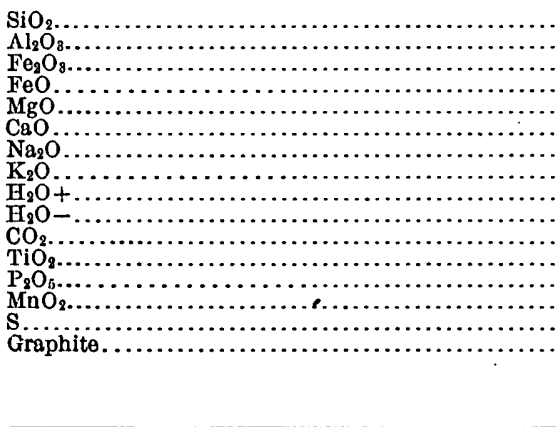 } & $\begin{array}{r}52.04 \\
19.40 \\
1.39 \\
9.34 \\
3.30 \\
4.34 \\
3.65 \\
3.25 \\
1.18 \\
.09 \\
\text { None. } \\
1.47 \\
\text { Trace. } \\
\text { (b) } \\
\text { None. }\end{array}$ & $\begin{array}{r}58.53 \\
16.70 \\
2.06 \\
6.26 \\
4.46 \\
2.34 \\
2.92 \\
3.22 \\
\text { a2. } 61 \\
\\
7.21 \\
\text { Trace. } \\
\text { Trace. } \\
.47\end{array}$ & $\begin{array}{r}44.53 \\
17.55 \\
3.38 \\
1.60 \\
5.68 \\
3.36 \\
3.60 \\
3.54 \\
1.66 \\
. .17 \\
.29 \\
4.33\end{array}$ & 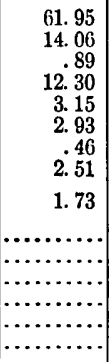 & 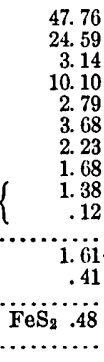 \\
\hline & 99.56 & 100.78 & $c 100.69$ & 99.98 & 99.97 \\
\hline
\end{tabular}

a Ignition.

$b$ Not determined.

c Traces of $\mathrm{Cl}, \mathrm{Cu}, \mathrm{Bi}, \mathrm{Ni}$, and $\mathrm{Ba}$.

1. Pseudoporphyritic kinzigite, Preston, Conn. G. F. Loughlin, analyst.

2. Kinzigite, Vormthal bei Schenkenzell, Schwarzwald. Rosenbusch, H. von, Elemente der Gesteins-

lehre, 1901, p. 487.
3. Kinzigite, Vormthal bei Schenkenzell. Weber, E., Min. pet. Mitt., vol, 6, 1884, p. 25.

4. Kinzigite, Gaderheim, Odenwald. Lepsius, R., Notizbi. f. Erdkunde, Darmstadt, 1881, p. 19.

5. Kinzigite, locality not given. Rosenbusch, H. von, op. cit.

These analyses, though similar in some respects, show how great a range in chemical composition may exist in rocks of similar mineral composition. That of the rock of the Preston area lies near the average of the other four. The analyses, as a whole, are not unlike those of certain igneous rocks, though certain features may be detected in them which point to sedimentary origin. The most conspicuous of these is the graphite in analyses 2 and 3 . The $\mathrm{Al}_{2} \mathrm{O}_{3}$ in No. 5, when its molecular ratio is compared to the sum of those of $\mathrm{CaO}, \mathrm{Na}_{2} \mathrm{O}$, and $\mathrm{K}_{2} \mathrm{O}$, has an excess of 0.121 . Only seven of the igneous rocks tabulated by Washington ${ }^{1}$ carry a great proportion of $\mathrm{Al}_{2} \mathrm{O}_{3}$, and of these, four contain a high percentage of corundum in the mode. Thus, while igneous rocks do occur with a large excess of $\mathrm{Al}_{2} \mathrm{O}_{3}$ over lime and alkalies, they are very rare, and the great excess of $\mathrm{Al}_{2} \mathrm{O}_{3}$ may be regarded as suggestive of sedimentary origin. The excesses of $\mathrm{Al}_{2} \mathrm{O}_{3}$ in columns 1 to 4 , inclusive, are, respectively, 0.017, 0.041, 0.018, and 0.051 -amounts scarcely great enough to suggest sedimentary origin.

Thus while certain features in analyses 2,3 , and 5 point to sedimentary origin, 1 and 4 are doubtful, and sustain the conclusion reached by Rosenbusch ${ }^{2}$ that kinzigite is a crystalline schist, the chemical composition of which in certain respects bespeaks eruptive origin, but the general mineral composition and geologic relations of which can not be reconciled to such a conclusion.

Variations.-The following variations in mineral composition from the typical rock were noted: (1) Biotite, accompanied by a low percentage of common hornblende; (2) andesine as dominant feldspar

\footnotetext{
1 Washington, H. S., Prof. Paper U. S. Geol. Survey No. 14, 1903, pp. 214-217.

2 Rosenbusch, H. von, Zur Auffassung der chemischen Nature des Grundgebirges: Min. pet. Mitt., vol. 12,1891, p. 56 .
} 
and hornblende dominant over biotite; (3) distinct crystal grains of epidote and zoisite in otherwise typical rock; (4) high percentage of quartz and little or no garnet; (5) microcline as dominant feldspar; accompanied by much quartz and little or no garnet. Of these variations, 1 and 2 point to a gradation into hornblende schist; 4 and 5 to a gradation into feldspathic quartz schist.

Origin.-From accumulated though incomplete evidence three hypotheses are suggested for the origin of the kinzigite, but no single one of them will serve to explain the formation as a whole. If we base our reasoning on mineral composition and sedimentary character, the kinzigite of the Preston region was evidently derived by the recrystallization of a fine-grained, highly ferruginous sediment containing considerable amounts of magnesia, lime, and alkalies, probably in fine mineral particles, and possibly to some extent as soluble salts. Most of the iron and magnesia, with practically all the potash and a proportionate amount of the alumina, went to form biotite, the body of the rock. Of the remaining constituents, the soda and much of the lime united with alumina and silica to form acidic plagioclase; the surplus of iron and alumina, with any of magnesia and lime, went to form garnet; the excess of silica crystallized as quartz. The plagioclase and garnet evidently grew by the accretion of molecules around centers of crystallization. The finer the material the more readily could such accretion take place.

The high percentage of iron oxides and the moderate amounts of magnesia and lime suggest that the ferruginous sediment was derived from some basic rock. As the Preston gabbro was intruded into the kinzigite, the only basic rock in the vicinity from which the latter could have been derived is the basaltic tuff, now metamorphosed to hornblende schist. The question now arises as to the method of derivation, and the three hypotheses suggested are as follows: The kinzigite resulted from a mixture of argillaceous sediment with the tuff; it was a sediment derived from the tuff; or it represents certain beds in the tuff which had been altered by percolating waters previous to recrystallization.

Interbedded relations between the kinzigite and feldspathic quartz schist, as well as variations 4 and 5 mentioned above, occasionally noted under the microscope, show that there was an alteration and perhaps at times a mingling of material from basic and granitic sources. Thus it might be supposed that the kinzigite was a gradation from basaltic tuff to sediment of a granitic character. The variation in texture from that of the hornblende and feldspathic schists to that of the kinzigite may be attributed to the fineness of the original material. Where either the tuff or granitic sediment were of sandy, uniformly grained character, they would recrystallize into uniformly grained schists; but where they had the character of fine mud, chemical trans- 
fer would take place more readily and the development of feldspar and garnet pseudophenocrysts would be possible. Thus the basic slate would be developed from exceedingly fine-grained tuff, and the microcline variety of kinzigite (variation 5, p. 74) could be developed from very fine granitic detritus.

A mingling of materials of sandy and undecomposed character would result in a schist containing quartz and alkalic feldspar and also a marked amount of plagioclase and hornblende, since all these minerals are stable under conditions of simple recrystallization. One thin section, noted as a gradation between the hornblende schist and feldspathic quartz schist (p. 63), agrees fairly well with this theoretical composition.

If the mingled materials were exceedingly fine, and the granitic detritus was largely reduced to kaolin, chemical change would accompany recrystallization, since kaolin is not stable under the conditions of recrystallization. The kaolin would unite with iron in the tuff to form garnet; any potash present could react with hornblendic material to form biotite; any soda would serve to increase the sodic character of the plagioclase; any excess of silica over that needed to form the new silicates would crystallize as quartz. Thus, qualitatively, the typical kinzigite could be produced. But the attempt to check this result quantitatively in the chemical analysis proves unsuccessful. As the quantitative mineral composition of the typical hornblende schist was found, under the microscope, practically to coincide with that of the supposed amphibolite sheet represented by analysis $3 a$ (p. 114), this analysis may be taken for comparison with that of the kinzigite (p. 73). The latter contains an excess of $3.99 \mathrm{SiO}_{2}$, $2.59 \mathrm{Al}_{2} \mathrm{O}_{3}, 2.14 \mathrm{Na}_{2} \mathrm{O}$, and $2.33 \mathrm{~K}_{2} \mathrm{O}$; and a deficiency of $4.85 \mathrm{MgO}$ and $6.51 \mathrm{CaO}$. If all the excess of $\mathrm{Al}_{2} \mathrm{O}_{3}$ were calculated as kaolin, it would represent 6.6 per cent kaolin in the original sediment. The available $\mathrm{SiO}_{2}$ is somewhat in excess of that required by the kaolin; and this excess could be regarded as quartz flour, but there is no way to account for the large excesses of alkalies. Even if the $\mathrm{Al}_{2} \mathrm{O}_{3}$ had been calculated as orthoclase, there would still have been a considerable excess of $\mathrm{K}_{2} \mathrm{O}$. The large deficiencies of $\mathrm{MgO}$ and $\mathrm{CaO}$ can not be accounted for by the addition of so small an amount of kaolin. It therefore seems more plausible to attribute the kinzigite's origin to chemical alteration of the tuff prior to recrystallization.

It has been shown (p. 67) that a recrystallized sedimentary derived from a basaltic rock would probably be characterized by a marked amount of garnet with perhaps other metamorphic minerals and by a relatively acidic plagioclase - characters which the kinzigite presents. The occurrence of two pebble-like inclusions of hornblende schist in the kinzigite suggests that some beds at least of the latter were derived by the erosion of the former; but the presence 
of gradations between the two and of conformable interbeds of kinzigite in hornblende schist at a number of places forces the conclusion that such an origin of the kinzigite must be rather exceptional. It is barely possible that the pebble-like inclusions may be small volcanic bombs in the tuff, a point beyond the limits of discussion.

If certain beds of the tuff had undergone alteration by percolating waters, which leached out some magnesia and lime and brought in potash with possibly a little soda, there would result a product with a chemical composition like that of the kinzigite. Furthermore, the resulting decomposition products would be unstable under the conditions of recrystallization and would give rise to the minerals present in the kinzigite. The basic plagioclase, leached of much of its lime, would form a more sodic variety; the potash could unite with the partly decomposed hornblendic or pyroxenic matter and form biotite; the kaolin derived from the basic plagioclase would unite with iron oxides and form garnet. The amounts of these minerals would vary with the degree of alteration in the original tuff bed.

These chemical changes and minerals are those commonly found in schists. - All the necessary constituents save the $\mathrm{K}_{2} \mathrm{O}$ were present in the original rock. The $\mathrm{K}_{2} \mathrm{O}$ must, according to this view, have been supplied by infiltrating waters. Such waters may have been derived from the consolidating Sterling granite gneiss, which is believed to have been intruded during the period of metamorphism. Sheets and stringers of the granite are plentiful in the kinzigite area, but the kinzigite interbeds themselves show no special affinity to the granite. Where microcline is the chief feldspar of the kinzigite, this influence of the granite seems more probable than where oligoclase predominates. Though it has its defects, this hypothesis, which regards the typical kinzigite as representing more or less altered beds of basaltic tuff, accords with the general facts, both petrographic and structural, better than the two previously discussed. The occurrences of the basic slate, the microcline variety of the kinzigite, and the pebble-like inclusions of hornblende schist must be regarded as minor exceptions which may require the special explanations above suggested.

\section{DOLOMITE.}

Megascopic characters.-The dolomite of the area, which is best exposed at the old North Stonington limekiln, is a medium to fine grained, thoroughly crystalline rock. The purest specimens are grayish white, crossed by faint dark bands which mark the original bedding. The rock, whose purest portions are limited to the central portion of the bed, becomes decidedly impure toward the edges and is filled with diopside, tremolite, actinolite, phlogopite, and minute grains of pyrite. All gradations can be found among different beds 
from nearly pure dolomite to rock composed entirely of the abovenamed silicates. The weathered surface may have a yellowishbrown tint due in part, at least, to the oxidation of pyrite; or it may be of a decided green color due to a considerable percentage of actinolite.

Microscopic characters.-The minerals revealed by the microscope, besides those already noted, are chondrodite and serpentine. The texture is unevenly granular and somewhat schistose.

The dolomite grains vary from 2 or 3 millimeters in length in the coarser-grained rock down to fine granules 0.1 millimeter in diameter. The larger grains have a generally lenticular outline, polysynthetic twinning, and a parallel arrangement. Their interspaces are filled with fine granules, which give a close resemblance to flaser structure. Sections from near the edges of the bed display a finely granular groundmass of the dolomite containing a few large grains of generally rounded outline. The fact that limestones and dolomites recrystallize so readily under pressure leads one to doubt whether the texture is really due to granulation by mashing or whether the larger grains are not the result of secondary crystallization whereby several small granules have united to form one large one; but the partial granulation or flaser structure in the central part and the more completely granular texture nearer the edges favors the view that the rock, already crystalline and with twinning developed, suffered granulation during the folding movement. The edges of the bed, where the shearing stress was greatest, were highly granulated, while the central part was only slightly affected. The shearing movement must have been too rapid to permit coarse recrystallization. From the fact that no later recrystallization has taken place and destroyed the granulated character, it may be inferred that the dolomite has not been very deeply buried since the period of folding.

The diopside is grayish white, appearing in some specimens in crystal fragments over 15 millimeters in length, but more commonly in granular masses. The crystal fragments possess a good cleavage, and some sections cut parallel to the cleavage show polysynthetic twinning, which gives them a strong resemblance to plagioclase, save for their higher index of refraction. Tremolite and actinolite, not abundant as a rule, present their usual characters. The only striking feature is the inclusion in the tremolite of diopside in droplike grains, which, owing to their general lack of cleavage or definite form, may not be readily recognized. The phlogopite occurs sparsely, partly in crystals measuring as much as 1.5 millimeters across the cleavage, but more commonly in finely disseminated flakes. In hand specimens it is nearly black, but is distinguished from biotite under the microscope by its weaker pleochroism. Chondrodite and serpentine are of rare occurrence and present no noteworthy characters. 
Variation.-One thin section, from a specimen taken at the contact of the dolomite and hornblende schist, shows an intermediate composition, bands predominating in tremolite alternating with bands rich in green hornblende. This arrangement, though it may point to rapid gradation, does not furnish the conclusive evidence afforded by the association of actinolite bands within areas of hornblende schist.

GENERAL PROMINENCE OF PLAGIOClase.

The petrography of the sedimentary rocks should not be dismissed without calling attention to the general presence of plagioclase, save in the dolomite. The plagioclase, more than any other mineral, serves as a connecting link to bind the several members of the series together. Different origins for the mineral have been suggested in the preceding pages, according to the respective weights of evidence. Thus, in the feldspathic quartz schist, the presence of plagioclase with some orthoclase led to the statement that the original sediment was an arkose; in the hornblende schist basic plagioclase is believed to have recrystallized without any marked chemical change; in the kinzigite, acidic plagioclase has, like garnet, been clearly developed as a product of metamorphism. No attempt will be made to discuss the subject further in these pages, but the facts here presented raise an interesting question of the origin and significance of plagioclase in metamorphic rocks-a question which further evidence and study may help to solve.

\section{PRESTON GABBRO.}

TYPES.

The Preston gabbro presents two principal variations: (1) A coarse porphyritic rock with large poikilitic phenocrysts of diallage, and (2) a quartz-hornblende gabbro. The former, as shown on the geologic map (Pl. II, in pocket) constitutes the greater part of the area; the latter lies along the western border of the main mass, broadening southward and including Prentice Mountain. In other words, the quartz-hornblende phase forms the upper part of the inclined sill-like mass. The two varieties are believed to grade into each other. Each variety contains minor variations and local intrusions. Those in the porphyritic rock include segregations of norite, olivine gabbro, and pyroxenite, segregations and dikes of basic pegmatite, and small dikes of diabase; those in the quartz-hornblende gabbro are local dikes of basic pegmatite and aplite, small rounded segregations resembling the porphyritic rock, irregular patches of quartz anorthosite and hornblendite, and, most striking of all, segregations and local intrusions of oligoclase granite. 
The exact nature of the outliers is obscured by metamorphism, but they present in general characters intermediate between the two principal portions of the main mass. The amphibolite sheets in the surrounding schists are partly intermediate and partly resemble highly sheared portions of the porphyritic gabbro.

PORPHYRITIC GABBRO.

NORMAL PHASE.

The coarse-grained porphyritic gabbro is typically developed around the several mountains within its area, though its granularity and fabric vary irregularly within short distances. The materia] from which the chemical analysis was made was collected on the steep, westward slope in the central part of area, between Bay Mountain and Broad Brook.

MEGASCOPIC CHARACTERS.

The color is dark greenish black, spotted with dark purple. The texture is coarsely porphyritic granular, but many of the large poikilitic diallage phenocrysts are easily overlooked owing to their color, which is very close to that of the groundmass. They range in length from a fraction of an inch to over 2 inches, and have a maximum width of at least an inch. Their distribution is irregular. In some specimens measuring 3 by 4 inches only one is visible; in others, phenocrysts comprise the greater part; probably they average from 20 to 30 per cent of the rock. They are best recognized by their broad cleavage faces, mottled by automorphic purple plagioclase laths, 1 to 5 millimeters long, which may comprise over 40 per cent of the surface. Small anhedral grains of ilmenite and pyrite are also commonly included. The phenocrysts are anhedral and grade into the feltlike groundmass.

The groundmass owes its feltlike character to a mass of unoriented uralite needles. These, like the phenocrysts, inclose hypautomorphic grains of purple plagioclase and anhedra of ilmenite and pyrite. This relation of phenocrysts to groundmass suggests that the porphyritic character may be the result of deformation of a coarse-grained diallage rock; that is, that the phenocrysts are unaltered remnants. This, however, is not borne out by microscopic evidence, which shows the phenocrysts abutting against smaller poikilitic diallage grains.

Although the rock has undoubtedly been subjected to compression it generally shows little or no gneissic structure, save along shear zones a foot or two in width, where the rock has been converted to an amphibolite which grades on both sides into the typical massive rock. In, some instances large phenocrysts have been so stretched as to resemble lenticular veinlets 4 or 5 inches long. This development is best seen at the summit of Ayer Hill. The weathered outcrops commonly present pitted surfaces, due to the dropping out of 
the feldspar grains from the weathering pyroxene or uralite matrix; but in places where feldspar is abnormally abundant, it is left in relief, producing a lumpy or "warty" surface.

MICROSCOPIC CHARACTERS.

Mineral structure.-Under the microscope (Pl. V, B, p. 42) the original texture of the rock is poikilitic diallage crystals measuring from 1 millimeter up forming the groundmass. The primary minerals found are diallage ( 47 to 55 per cent), labradorite ( 45 to 50 per cent), ilmenite ( 1.2 to 2 per cent), and pyrite (0.1 to 0.4 per cent). Apatite is very rare and irregularly distributed, the analysis of a composite sample (p. 114) recording no $\mathrm{P}_{2} \mathrm{O}_{5}$. Two thin sections (Nos. 28 and 29) show rare biotite which is, in part at least, original. The secondary minerals, which are very irregularly distributed, are uralite, brown hornblende, epidote, clinozoisite, scapolite, albite-oligoclase, white mica, chlorite, calcite, quartz, and ferric oxide.

Diallage.-The diallage presents no unusual characters. The parting parallel to 100 is well developed, and schiller structure in some crystals is very evident. The maximum extinction angle noted is $40^{\circ}$. The freshest examples are light brownish in color owing to the schillerization and are not pleochroic. Polysynthetic twinning is common. Most grains, however, have a pale-greenish color, slight pleochroism, and an obscured extinction angle owing to the incipient development of uralite needles along the cleavage. Most of the pale-green grains are thoroughly sprinkled with a fine black dust, presumably magnetite. Uralite fibers also form minute shear planes diagonal to the cleavage, and are terminated by included labradorite laths. Where, as is mostly the case, metamorphism has been sufficiently severe, the diallage has been transformed into a mat of uralite fibers. These still preserve distinctly the poikilitic texture, save where the rock has been most severely drawn or stretched along local shear zones into a schist. The detailed description of the dynamic metamorphism is given in a later paragraph. Where chemical alteration has taken place, alteration of diallage and uralite alone have yielded chlorite, which must have originated since the metamorphic period, perhaps as a product of weathering. Along the contacts between diallage and labradorite, reaction rims of epidote have formed in some places, and in several sections borders of secondary brown hornblende are prominent. The latter deserves special mention.

Secondary brown hornblende.-Secondary brown hornblende is present in many, but by no means all specimens, varying from a mere trace up to 2 per cent and more. It is confined to those thin sections in which the diallage is well preserved, and almost without exception forms contact borders between epidotized labradorite and 


\section{PLATE IX.}




\section{PLATE IX.}

A. Photomicrograph of diallage crystal in gabbro, showing rims of brown hornblende along the contacts with feldspar. The black veinlet at $l-l$ is limonite. Magnified 30 diameters. Without crossed nicols. Section 30 .

$B$. Photomicrograph of partly saussuritized gabbro. The upper left-hand quarter shows a labradorite crystal $(l)$ with but little alteration. The right-hand half shows an extinguished labradorite cut by a network of albite veinlets $(a), S$ denotes scattered grains of sericite. The lower left-hand portion shows an aggregate of epidote and zoisite $(z)$ with some sericite, albite, and quartz, completely replacing labradorite. Magnified 130 diameters. Nicols crossed. Section 41 .

82. 


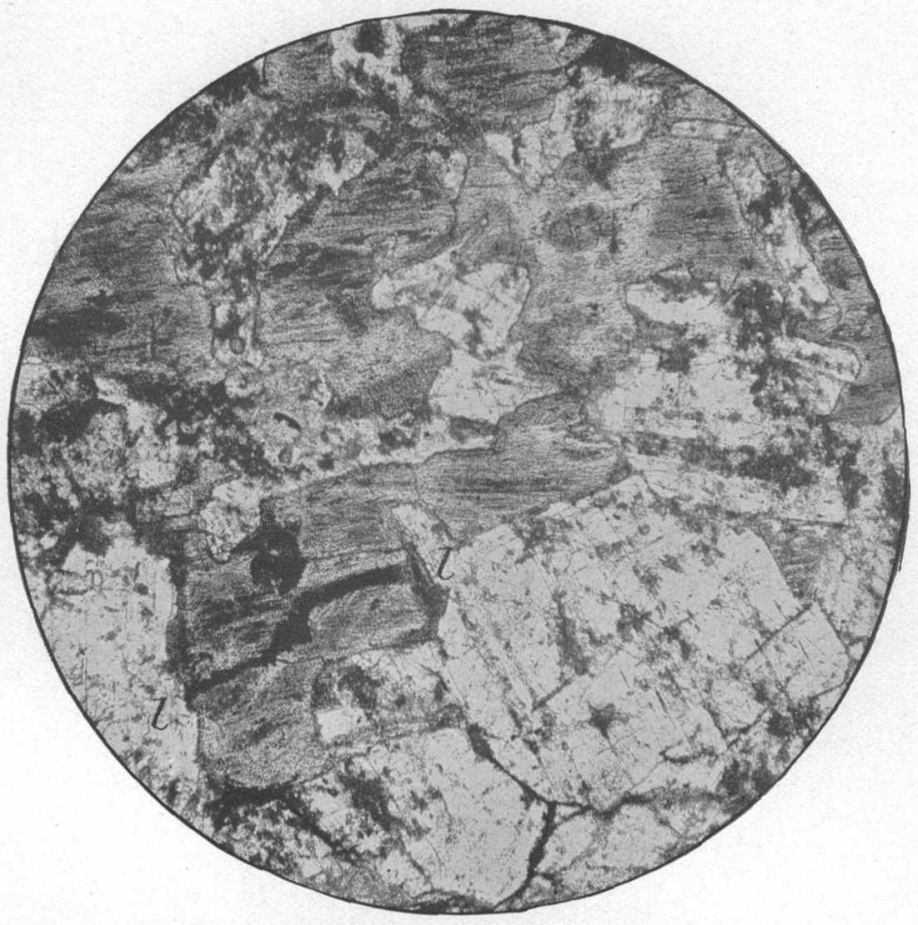

A.

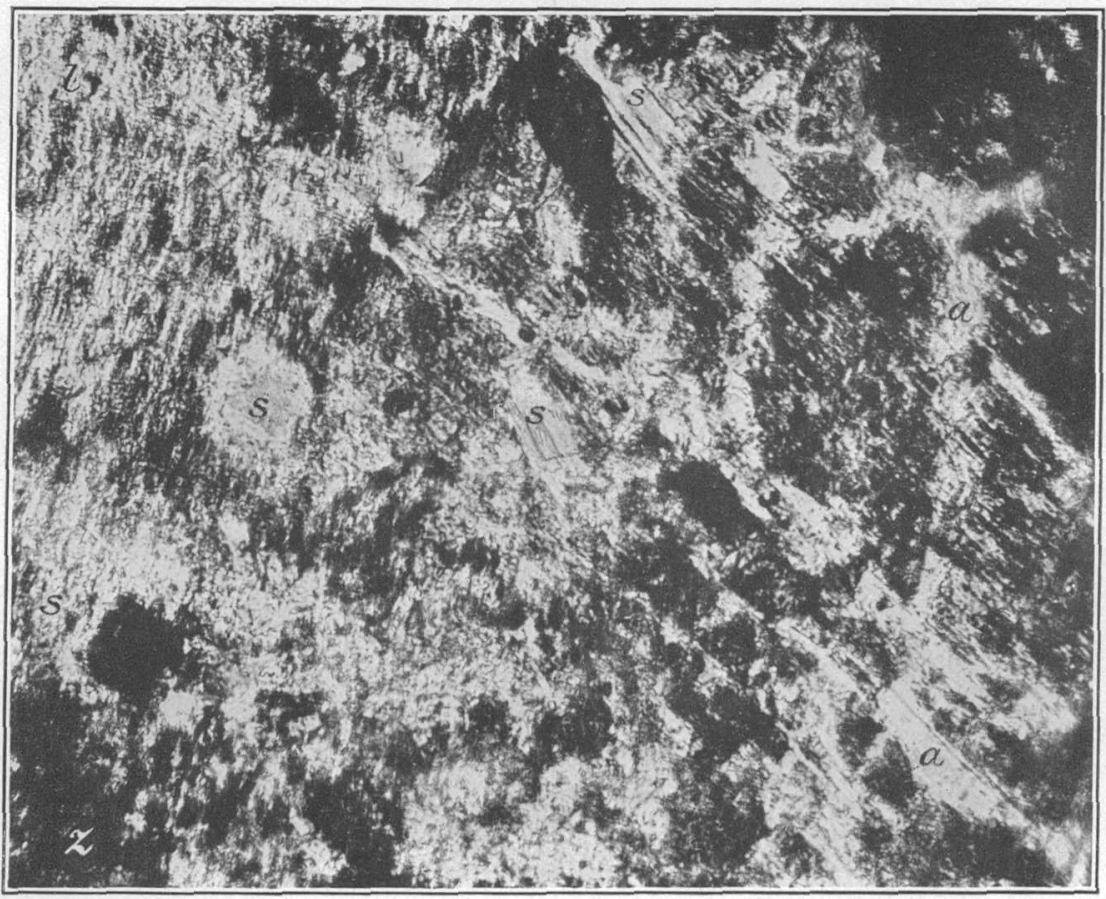


either diallage or certain chlorite-magnetite areas which are closely associated with diallage. It is in most cases compact and is strongly pleochroic where not bleached. Its high maximum extinction angle $\left(37^{\circ}\right.$ to $\left.40^{\circ}\right)$ agrees with that of an anomalous basaltic hornblende from Aranyer Berg. ${ }^{1}$ Its cleavage in many cases does not coincide with that of the diallage, but tends rather to lie normal to the edge of the feldspar. It has a sharp contact with the latter, but fades into the former and tends to form pseudomorphs after it, preserving the poikilitic inclusions, but not necessarily the cleavage directions. Where it borders the chlorite-magnetite areas its contacts are sharp, as though it had replaced the inclosing or adjacent diallage along the contact, which may have been a favorable channel for the agencies producing the change. In a very few specimens the brown hornblende is not exactly at the contact, but these are where subsequent alteration at the contact is now active in, or has already brought about bleaching or chloritizing, the brown color fading toward the contact.

All the clearest and most unaltered examples suggest strongly that the brown hornblende is the result of a reaction between the labradorite and diallage. (See Pl. IX, B.) Such a reaction, qualitatively at least, is very possible. According to analyses which the writer has found scattered through several publications, brown hornblende runs distinctly higher in $\mathrm{Na}_{2} \mathrm{O}$ than do diallage, uralite, or common green hornblende. It is also characterized by high alumina and iron, and may contain over 5 per cent of $\mathrm{TiO}_{2}$. Transfer of $\mathrm{Na}_{2} \mathrm{O}_{3}$ with some $\mathrm{Al}_{2} \mathrm{O}_{3}$ from labradorite to diallage would give the requisite chemical composition, and where ilmenite is present, as often noted, the percentages of iron and titanic oxide may run high. The diallage thus could be converted completely to brown hornblende. The lime of the labradorite would go to form clinozoisite or, aided by a little iron from diallage or ilmenite, to form epidote, both of which are commonly present. Whatever the exact nature of the reaction, it took place prior to dynamic metamorphism, for the brown hornblende has suffered uralitization along with diallage, though not so rapidly. Comparative study of several sections (Nos. 28, 30, 51, 52, 53,60 ) show first, partly changed diallage with a border of compact though somewhat bleached brown hornblende; seconc, Jiallage completely changed to a mat of small, weakly pleochroic uralite needles with a border of more strongly pleochroic compact, but green, hornblende (the passage from the bleached brown to the green showing fairly well in sections Nos. 28 and 53); and third, where a tendency to schistose development appears, the rim has become broken into differently oriented fibers, and the form of the original mineral gradually disappears. 
Compact brown hornblende secondary after pyroxene has been described and figured by many writers. The subject was reviewed and discussed by G. H. Williams in $1890,{ }^{1}$ but in all citations the alteration of monoclinic pyroxene to brown hornblende was attributed to molecular rearrangement due to heat and pressure. The derivation of brown rather than green hornblende was supposed to depend on the composition of the original pyroxene. C. H. Gordon ${ }^{2}$ doubts this secondary origin of compact hornblende, but recognizes the secondary nature of hornblende bands bordering irregular fractures in augite. F. W. Clarke, ${ }^{3}$ in summing up the subject, states that the change of pyroxene to amphibole is something more than a paramorphism, but makes no special mention of brown hornblende.

Judging from the Preston gabbro as well as from some of the illustrations above cited, the development of brown hornblende takes place before the rock suffers noticeable mechanical deformation. It may well be that pressure and heat have awakened the activity of the agencies that produced the change, but where mechanical movement has taken place, even to a slight extent, the pyroxene has recrystallized independently, though into pale-green uralite, whereas more pronounced deformation has caused uralitization of the brown hornblende.

Biotite.-Biotite is rare, forming thin tablets less than 0.5 millimeter in length. Its presence in sections shows but slight deformation, and its relations to other minerals (included without definite orientation in diallage, brown hornblende, and ilmenite) point to its primary origin, though a few occurrences are of doubtful origin. The rare presence of biotite is a possible sign of gradation toward the quartz-hornblende variety, of which biotite is a constant minor constituent. The biotite is in some specimens altered to chlorite; in others it is partly bleached.

Labradorite.-The feldspar, according to M. Lévy's method of finding extinction angles on combined Carlsbad and albite twins, is basic labradorite $\left(A b_{3} A_{4}\right.$ to $\left.A_{2} \mathrm{An}_{3}\right)$ though a few grains appear even more basic. It forms lath-shaped, hypautomorphic crystals, some separate, but the majority in groups or. with ends attached. Pericline twinning is common, and several crystals are curved or bent; but marked granulation is limited to the distinctly schistose rock in local shear zones.

Two kinds of minute inclusions are present in the feldspar-hornblende (uralite) and minute black dustlike particles thought to be ilmenite or magnetite. The hornblende, even in the most undisturbed rock, forms minute laths, or needles, not unlike the typical apatite laths

1 Bull. U. S. Geol. Survey No. 62, 1890, pp. 52-55, 72, 211, Pl. VIII.

2 Am. Geologist, vol. 34, 1904, p. 42.

s Data of geochemistry: Bull, U, S, Gcol, Survey No. 330, 1908, p. 508. 
in granites. The larger are readily identified by their pale-greenish color, pleochroism, and extinction angles, but the smaller are quite colorless and their extinction angles are masked by those of the feldspar. Such an occurrence was described by G. H. Williams.' He attributes the occurrence to the infiltrations of iron and magnesia along the cleavage cracks of the feldspar and its reaction with the latter. These needles in the specimens in hand, especially if the rock has been disturbed, may be so numerous as to form distinct veinlets from the ferromagnesian mineral into or between the feldspars; but in the least-disturbed occurrences they are so independently oriented in fresh feldspar that some doubt might well exist as to their metasomatic origin. Numerous observations, however, show a marked gradation from the thinly scattered needles to the distinct veinlets.

The minute dustlike inclusions are very prominent in this, as in the feldspar of many other gabbros, and are evidently the cause of

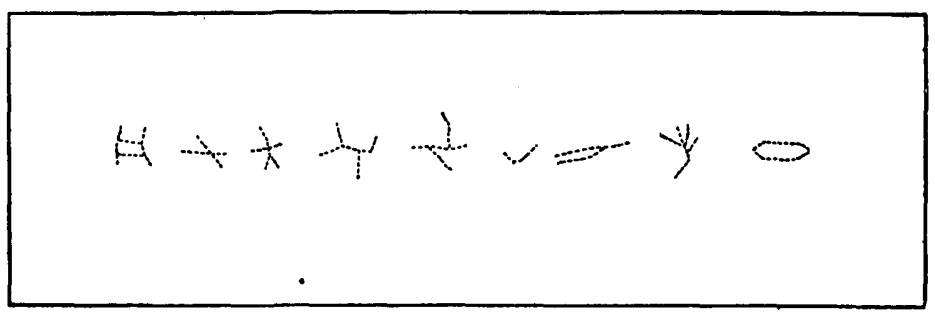

FIGURE 15.-Black dustlike inclusions in feldspar of gabbro.

the purple color of the feldspar, which is faintly noticeable even in some thin sections. Under a high power the purple color disappears, and the inclusions are seen to be thickly and uniformly distributed. They consist of minute black specks, which lie in rows along twinning planes, as well as in irregular distribution throughout every lamella. In some places they are equidimensional and separate; in others they lie in linear groups of two or more, and in still others they form solid rods where several specks have grown together. Though some specks are opaque and resemble black iron oxide, others, larger than the ordinary, are undoubtedly fluidal inclusions. A few specks are red, suggesting hematite. The rods and linear groups are all opaque and black and in some places unite, roughly assuming shapes of crystallites. Such inclusions in the feldspars of gabbros, especially of the older formations, have been described by several petrographers. A review of their conclusions is given by Rosenbusch. 2 They are generally thought to be ilmenite or, in some specimens, rutile; but in one occurrence (the gabbro from Ehrsberg, in the southwestern

1 The greenstone schist areas of the Menominee and Marquette regions of Michigan: Bull. U. S. Geol. Survey No. 62, 1890, p. 215.

2 Mikroskopische Physiographie der massige Gesteine, 3d ed., 1895-96, p. 280; 
Schwarzwald) the amethystine color of the labradorite was attributed to manganese. In other occurrences they have been described as augite and as glass inclusions. They occur independent of the composition of the feldspar, and have been found in all varieties from andesine to anorthite. Williams, ${ }^{1}$ when studying the Baltimore gabbro, was unable to determine their mineralogical nature by either microscopic or chemical means. E. S. Dana, ${ }^{2}$ in describing ossipyte, considered these fine inclusions to be titanic iron. In the present specimens (fig. 15) the groups of joining rods, suggestive of crystallites, are not unlike geniculate twins of rutile needles; but the single specks, by their black, opaque character and their shapes, are more suggestive of ilmenite or magnetite.

The effects of chemical alteration on the feldspar are very irregularly distributed and have no definite relation to dynamic metamorphism. In some thin sections of both massive and highly schistose rock the mineral is practically fresh, and in others it is almost completely altered. The chief alteration products are epidote, clinozoisite, scapolite, albite, oligoclase, and, in a few instances, a white mica. These minerals commonly occur together in the more or less opaque masses known as saussurite; but epidote, as already noted, in many specimens forms reaction rims along contacts of feldspar, diallage, and ilmenite.

The epidote, which is frequently the most abundant member of the saussurite aggregate included in the feldspar grains, implies a transfer of iron from the pyroxene. It forms many compact, almost nonpleochroic grains, some over 1 millimeter long, but is for the most part finely granular and intimately mixed with zoisite. The zoisite duplicates the epidote in habit and is nearly, if not quite, as abundant. Scapolite is not nearly so frequent or abundant. It forms small, irregular areas, only a few of which are large enough for identification under high power. These are recognized by rather high birefringence and negative, uniaxial character. The secondary feldspar, where present, commonly forms a clear, weakly birefringent groundmass for the other secondary minerals and less commonly traverses the labradorite in irregular veinlets. It is commonly without cleavage or visible albite twinning; where these properties are present their respective extinction angles are those of albite-oligoclase, but no very satisfactory sections for determination could be found. Secondary feldspar is prominent only in a few thin sections, but it is probably concealed in many others by the high index of refraction and the more pronounced birefringence of the abundant epidote and zoisite. White mica was identified in two sections only. It forms both sericitic areas

1 Bull. U. S. Geol. Survey No. 28, 1886, p. 21.

2 Contributions to mineralogy and petrography from the laboratory of Sheffield Scientific School, 1901, p. 387 . 
and very small compact grains ( 0.2 millimeter long), and is intimately associated with the secondary feldspar. The two have sharp boundaries and appear to have grown simultaneously. In such small grains there is no means of distinguishing between muscovite and paragonite. The minute quantity of $\mathrm{K}_{2} \mathrm{O}$ recorded in the analysis (No. 1, p. 114) is doubtless sufficient for the very slight amount of the mica; yet it may be questioned if paragonite could not have formed from the plagioclase. The fresh character of the secondary sodic feldspar, however, and its relation to the mica suggest that while the soda of the original labradorite went to albite-oligoclase and scapolite, the minute amount of potash passed into muscovite. Mica and scapolite were not noted in the same thin section. Saussuritic alteration is illustrated in Plate IX, $A$.

The probable impregnation of labradorite by uralite and the development of brown hornblende rims between labradorite and diallage have already been mentioned.

Ilmenite.-The black iron mineral is almost invariably xenomorphic, some grains attaining a length of over 1 millimeter. The few grains that approach automorphic character suggest both ilmenite and magnetite. The chemical analysis shows both molecules to be present, but failure of hot, strong $\mathrm{HCl}$ to produce any etching effects on a polished surface of the mineral proves it to be ilmenite. The principal character of the mineral is its irregular form, due to its relatively late period of growth. Where surrounded by feldspars, it generally fills interstices among them, and in some specimens even includes s.mall feldspar grains, though in a very few the opposite relation exists. Its relations to the diallage are similar, though inclusions of it in the pyroxene are more common than in the feldspar; but these inclusions are similar in their irregularity of form to quartz inclusions in the feldspar of graphic granites. In some cases two thick grains may be joined by a narrow, veinlike portion. Interstitial areas between diallage grains are not common and would perhaps be more prominent were the ilmenite more abundant and not entrapped by the poikilitic diallage. Plate XIV shows an extreme case where a poikilitic texture is developed in ilmenite. The fresh character of the rock in many sections and the sharp mineral contacts are proof that the ilmenite is not secondary. These relations show that the order of crystallization is, first, labradorite, and, second, diallage, with the iron mineral contemporaneous with or even slightly later than the diallage. This is just the reverse of the normal order in acidic rocks, but, so far as the writer has seen from study of thin sections and photomicrographs, is not uncommon among rocks of the gabbro type. This relation was pointed out by Williams ${ }^{1}$ in the olivine diabase of the northern portion 
of the Marquette area, and by Warren ${ }^{1}$ in the cumberlandite of Rhode Island, but mention of it in literature seems generally to be wanting. Alteration to leucoxene is slightly developed in several thin sections. Many grains in contact with feldspar are bordered by narrow rims of green amphibole needles. In disturbed portions of the rock the form and boundaries of the iron mineral become obscured, and in the extreme schistose phase it has been flattened and drawn into linear, veinlike masses.

Chlorite-magnetite aggregates.-Intimately associated with diallage or ilmenite in many places are small areas, almost none above 1 millimeter in diameter, of weakly pleochroic chlorite fibers, unoriented, and traversed in two or three directions by lines of a black metallic substance, presumably magnetite $(\mathrm{Pl} . \mathrm{X}, B)$. Two directions making an angle of $70^{\circ}$ to $78^{\circ}$ are the more common; the third, where present, lies at $57^{\circ}$ to $60^{\circ}$ to one of the other two. The magnetite lines may widen and unite into a continuous mass, obliterating their arrangement. Some of these areas are in contact with original ilmenite and are surrounded by rims of brown hornblende; others are quite independent of any primary metallic mineral and appear to be the remains of some inclusion in the diallage. The origin is doubtful. Where ilmenite and brown hornblende are present, it is possible that the development of brown hornblende has extracted some $\mathrm{TiO}_{2}$ from the ilmenite, setting free iron which crystallized as magnetite. The source of the chlorite may have been, in part or wholly, the $\mathrm{MgO}$ present in the ilmenite; but a chemical investigation would be necessary to decide. The only other source of the chlorite would be the diallage.

Where no titaniferous magnetite is present, it is possible that the chlorite was derived from some femic mineral inclosed in the diallage, and that the black metallic lines mark the locations of original schillerization, parting, or cleavage; but no conclusion is warranted as to the identity of such an inclusion.

Pyrite.-Pyrite, in grains up to 1 millimeter and more in diameter, is distributed fairly uniformly and for the most part tends toward an automorphic habit; but distinct xenomorphic grains, similar to those of the ilmenite are readily found inclosed in the pyroxene. Even the partly automorphic grains tend to branch at one end or to finger into the pyroxene. This relation classes the pyrite with the ilmenite in order of crystallization. In one specimen the two minerals were found in contact, but neither could be determined as the older. The automorphic edges are those of the cube, alone, or truncated by the octahedron. A border of secondary limonite is commonly present but is not sufficient to obscure the original outline of the pyrite.

1 Warren, C. H., Am. Jour. Scl., 4th ser., vol. 25, 1908, p. 20. 
PLATE $X$. 


\section{PLATE X.}

A. Photomicrograph of moderately mashed gabbro, showing the edge of a poikilitic diallage (black) in the upper left-hand portion. The rest of the area consists of unaltered feldspars in a mat of fine, unoriented uralite needles. The edges of the feldspars are penetrated by short uralite needles, and to a less extent by epidote. Magnified 30 diameters. Nicols crossed. Section 23.

$B$. Photomicrograph of chlorite-magnetite aggregate, showing arrangement of the two minerals. It is separated from the surrounding labradorite $(l)$ by a rim of uralitic hornblende. Magnified about 100 diameters. Without crossed nicols. Section 51. 

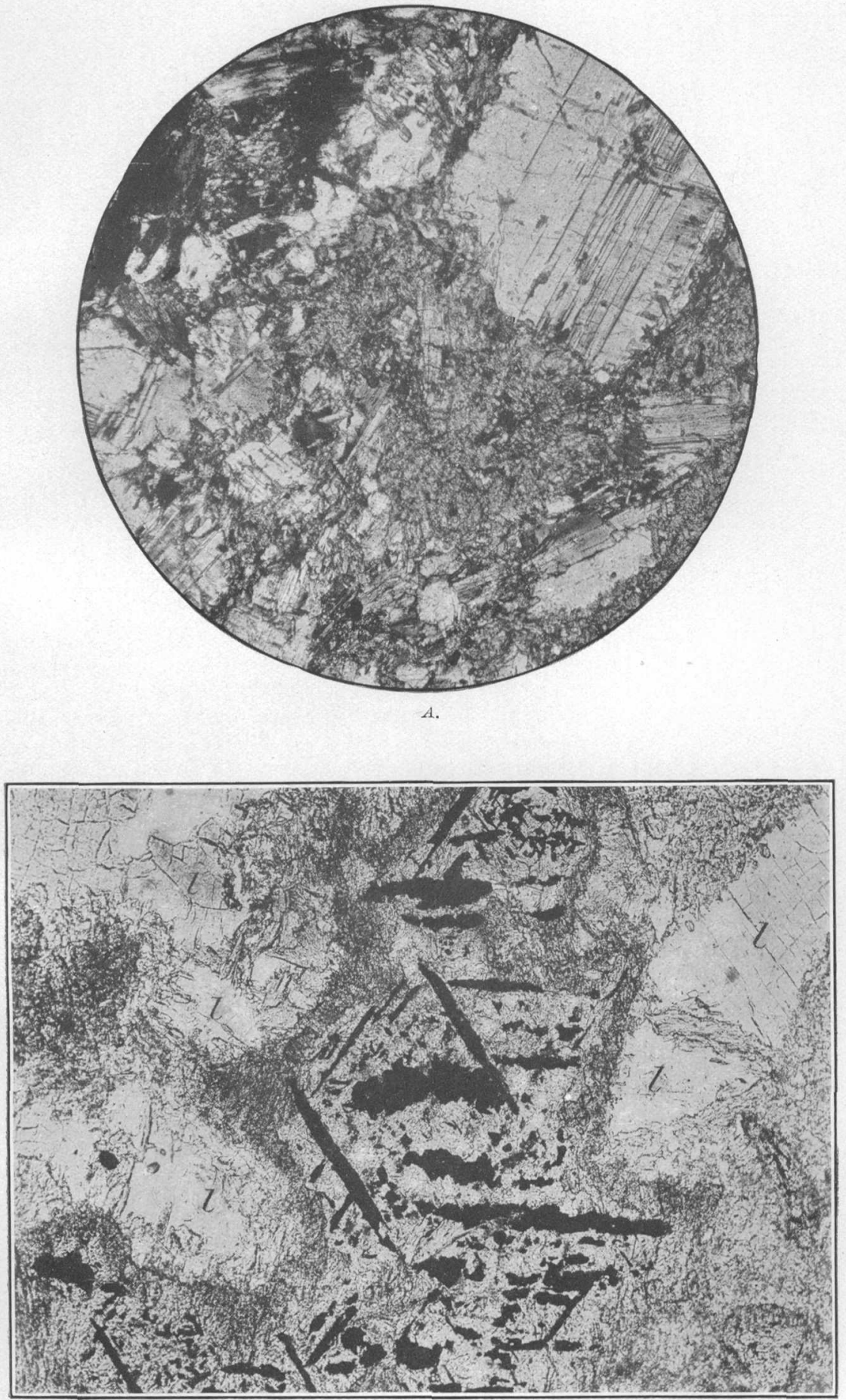

B. 



\section{PLATE XI.}

A. Photomicrograph of highly mashed gabbro. The feldspars have suffered some microscopic faulting and rotating. The uralite needles have assumed a schistose arrangement and also fill fault cracks in the feldspar. The ilmenite also has recrystallized into a distinctly schistose arrangement. Magnified 30 diameters. Nicols crossed. Section 24.

$B$. Photomicrograph of extremely mashed gabbro, showing typical schistose structure. The feldspars are finely granulated and in places have undergone saussuritic alteration. The uralite has developed into aggregates of compact hornblende crystals, uniformly oriented and inclosing many feldspar. aggregates. The ilmenite has been rearranged into streaks parallel to the schistosity. Magnified 30 diameters. Nicols crossed. Section 64 . 


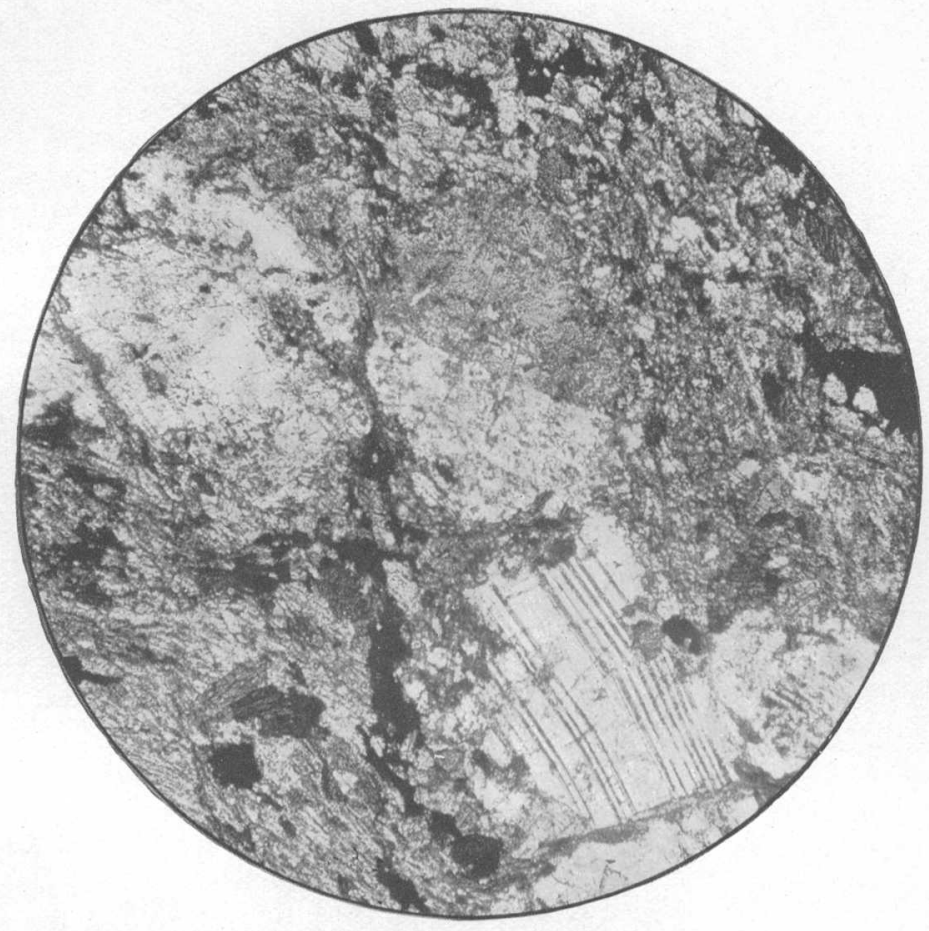

$A$.

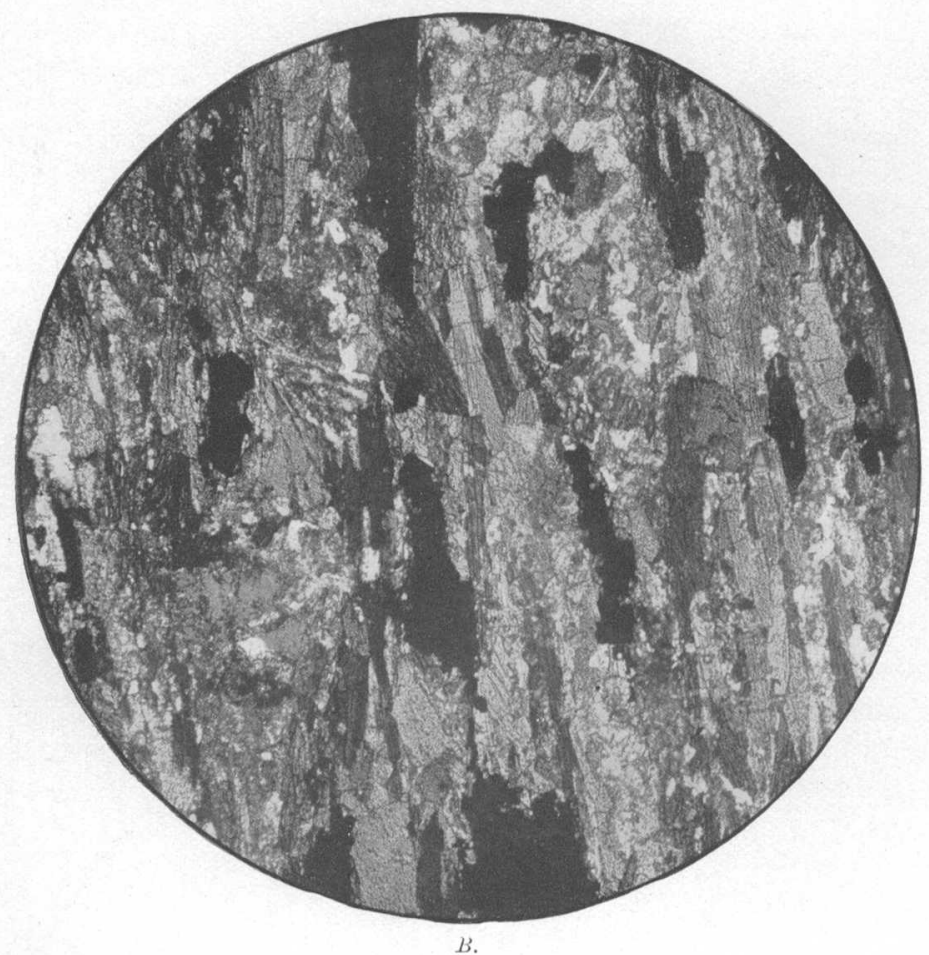


The only secondary minerals not already noted are quartz and calcite, which occur together in scattered microscopic veinlets. Quartz is also present in some of the more schistose specimens, forming minute, clear grains among the uralite fibers. Primary quartz was carefully looked for but was not found.

MECHANICAL AND CHEMICAL METAMORPHISM.

Mechanical movement is revealed by the presence of uralite veinlets along microscopic thrust faults, fractures, or cleavage, in diallage. (See $\mathrm{Pl} . \mathrm{V}, B, \mathrm{p} .42$.) This change progresses until the diallage is entirely replaced by a mat of uralite fibers. At this stage a few uralite crystals have become more prominent than the rest and indicate more or less distinctly a common orientation. The feldspar as a whole is unchanged, save for a minor amount of microscopic faulting. (See Pl. X, A.) Further movement develops a distinct schistosity. The feldspar grains become more broken and their fractures are penetrated by uralite veinlets. The uralite mat has united into more or less compact crystals, a few containing minute, clear grains of secondary quartz. The metallic minerals, hitherto unaffected, have become somewhat elongated parallel to the schistosity, and their contacts have a corroded appearance. (See Pl. XI, A.) The final stage, the extreme of schistosity, shows the feldspar fragments reduced to a finely granular state between long blades of compact green hornblende. The metallic minerals, especially magnetite, are drawn out into linear forms resembling veinlets. (See Pl. XI, B.)

The relations of chemical changes to mechanical deformation are not clear. The presence of most of the secondary minerals in unmashed areas indicates that crushing was not essential, and the presence of epidote and zoisite unmashed in the most highly schistose specimens shows that chemical, in some cases at least, followed mechanical change, either closely or remotely. Regarding the various chemical changes, it seems clear that the development of brown hornblende with any complementary development of zoisite, epidote, etc., preceded mechanical deformation; though it possibly was but a beginning of the succession of changes due to regional metamorphism. This was followed by uralitization during the mechanical movements. Uralitization, as shown by Williams ${ }^{1}$ and by Clarke, ${ }^{2}$ is accompanied by liberation of $\mathrm{CaO}$, which in the present case appears to have gone to epidote or zoisite. It may also have drawn on the $\mathrm{Al}_{2} \mathrm{O}_{3}$ and alkalies of the feldspar, thereby setting free

\footnotetext{
1 Williams, J. H., Greenstone-schist areas of the Menominee and Marquette regions of Michigan: Bull. U. S. Geol. Survey No. 62, 1890, pp. 52-55.

${ }^{2}$ Clarke, F. W., The data of geochemistry: Bull. U. S. Geol. Survey No. 330, 1908, p. 508,
} 
more $\mathrm{CaO}$ to form zoisite or epidote, the latter especially along contacts with diallage areas. The presence of secondary albiteoligoclase and white mica associated with epidote and zoisite suggests that the process of epidotization in feldspar, once started, progressed farther than was necessary simply to supply any $\mathrm{Al}_{2} \mathrm{O}_{3}$ and alkalies needed for uralitization, and that the albite-oligoclase and mica are complementary to the excess of epidote and zoisite developed. The association of some scapolite with these minerals shows the limited presence of chlorine in the thermal waters that were instrumental in these changes. The presence of leucoxene rims around ilmenite also points to the liberation of $\mathrm{CaO}$ from either pyroxene or feldspar, according to the mineral in contact with the ilmenite. The small rims of green amphibole between the iron mineral and feldspar are evidently reaction rims and point to the presence of some $\mathrm{MgO}$ in the former, as suggested on page 88. The relation of these rims to mechanical movement is indefinite.

The development of chlorite, calcite, vein quartz, and kaolin evidently followed the period of mechanical movement, and was probably produced after the rock had been raised into the belt of weathering. The alteration of uralite to chlorite proves the late development of the latter mineral, but the possible derivation of chlorite from spinel molecules in ilmenite during the development of brown hornblende suggests an earlier origin in that one case.

To sum up, there were three stages of chemical alteration: First, premetamorphic, marked by development of brown hornblende with perhaps some epidote-zoisite and chlorite; second, metamorphic, marked by uralite, epidote-zoisite, albite-oligoclase, white mica, scapolite, and leucoxene; and, third, postmetamorphic or weathering, marked by chlorite, calcite, vein quartz, and kaolin.

CHEMICAL COMPOSITION.

The chemical composition is given in analysis No. 1, page 114. Its discussion is deferred until the other varieties of the series have been described.

CLASSIFICATION.

The rock, according to the prevailing classification, is a porphyritic gabbro. According to the quantitative system, the rock belongs to Class III, order 6 , rang 3 , subrang 5 . No name has yet been given to this subrang, in which $\mathrm{Na}_{2} \mathrm{O}: \mathrm{KO}_{2}$ exceeds $7: 1$, and, as the high percentage of $\mathrm{Na}_{2} \mathrm{O}$ can not be accounted for, no name is here proposed.

\section{NORITE PHASE (AUVERGNOSE-HESSOSE).}

The only specimen containing orthorhombic pyroxene was collected in the northwest part of the area, as shown on the map. The bronzite was only detected by microscopic study, and the rock in the field 
differed in appearance from the main type only by the lack of poikilitic phenocrysts of diallage. This similarity and the rather extensive drift covering in the vicinity leave the exact limits of the mass and its structural relations in doubt; but its area can not greatly exceed that of the outcrop studied, and its general similarity to the main type leads one to regard it as a segregation.

\section{MEGASCOPIC CHARACTERS.}

The rock is medium grained, generally without gneissic structure, dark purple on fresh fracture owing to predominating feldspar, and dark green and pitted on the weathered surface. The megascopic minerals are plagioclase, pyroxene, uralite, ilmenite, and pyrite.

\section{MICROSCOPIC CHARACTERS.}

Mineral structure.-Under the microscope the texture is hypautomorphic equigranular. Ophitic or poikilitic habit is but slightly developed. The primary minerals present are labradorite (60 per cent), bronzite ( 22 per cent), diallage (12 per cent), ilmenite and pyrite (4 per cent), with no apatite; the secondary minerals are uralite, epidote, clinozoisite, scapolite, chlorite, talc, quartz, and ferric oxide. These, other than uralite, comprise only a very smali percentage ( 2 to 3 per cent) of the rock.

Labradorite.-The plagioclase, as determined by M. Léry's method for sections, showed combined Carlsbad and albite twins to be approximately $\mathrm{Ab}_{1} A \mathrm{n}_{1}$. Individuals present the same general characteristics of twinning and deformation as do those in the main type described, but tend to occur more in aggregates of several grains. A few grains, broken by minute thrust faults about 0.5 millimeter in length, have developed secondary twinning lamellæ along the fault plane. Minute dustlike inclusions giving rise to a purple color are abundant. (See p. 85.)

Bronzite.-Bronzite, where sufficiently fresh, is recognized by its parallel extinction and weak pleochroism, colorless to pale green. The grains are hypautomorphic with rounded ends and appear mostly to have crystallized slightly before the feldspar. Prismatic cleavage is well developed and the cleavage cracks are partly filled with ferric oxide. Schiller structure is well developed in at least two directions. Alteration to uralite is present in all stages from mere traces along the borders and cleavage cracks to nearly complete replacement. This alteration has, as G. H. Williams has shown, ${ }^{1}$ involved a reaction between the bronzite and adjacent feldspar. Aggregates of minute, brightly polarizing but indeterminate grains, thought to be talc, occur along the cleavage cracks of the bronzite. They are especially devel-

1 The gabbros and associated hornblendic rocks occuring in the neighborhood of Baltimore, Md.: Bull. U. B. Geol. Survey No. 28,1886 , p. 43. 
oped in the partly uralitized grains, and may have originated during the period of uralitization or at a later time. Evidence is inconclusive. Chlorite and possibly a little serpentine are also associated with a few bronzite grains, forming weakly pleochroic aggregates. Uncommonly they have migrated into the feldspar, forming minute shreds.

Diallage.-The diallage is identical with that of the porphyritic type in all properties save size. Some of it is partly surrounded by bronzite, but more commonly it partly surrounds the latter. It bears the same relation to the feldspar and is, on the whole, the youngest of the three primary silicates, though crystallization of them all must have been nearly contemporaneous.

Ilmenite and pyrite.-No pyrite was noted in thin section, though conspicuous in the specimen. The ilmenite is identical in all its proportions with that of the main type, and is regarded as contemporaneous with or later than the diallage in crystallization.

ALTERATION PRODUCTS.

The alteration products, save talc, which is mentioned in connection with the bronzite, are identical with those of the main type. The finding of small masses of soapstone (steatite) in the drift near the norite locality suggests that alteration to talc is much more extensive than the one thin section indicates. No brown hornblende was noted.

\section{CLASSIFICATION.}

The rock, according to the prevailing classification, is a norite; according to the quantitative system, it falls just within the basic limit of Class II, order 5, rang 4, subrang 3 , and is thus auvergnosehessose.

\section{OLIVINE GABBRO PHASE.}

The one specimen of the olivine-bearing phase was collected where the east-west road passes the 300-foot hill just northwest of Rixtown Mountain.

\section{MEGASCOPIC CHARACTERS.}

The general appearance of the specimen is very similar to that of the norite phase, though more closely related to the porphyritic type owing to the presence of poikilitic diallage; but the latter does not present any pronounced porphyritic appearance. Olivine occurs in fine grains, 1 to 2 millimeters in diameter.

MICROSCOPIC CHARACTERS.

Mineral structure.-The microscopic texture is generally hypautomorphic granular, and is poikilitic where diallage and ilmenite are well developed. The minerals present are by townite (about 60 per cent), 
olivine (22 per cent), diallage (5 per cent), ilmenite (4 per cent), and secondary brown hornblende (8 per cent). Other secondary minerals, uralite, epidote, zoisite, chlorite, etc., are very inconspicuous in the thin section studied, and present the same characters as in the main gabbro type. Fibrous amphibole, talc, and magnetite are conspicuous alteration products of the olivine.

Bytownite.-Extinction angles on the albite lamellæ of Carlsbad twins prove the feldspar to be bytownite $\left(A b_{3} A n_{7}\right.$ to $\left.A b_{1} A n_{4}\right)$. The felspar in form and habit is similar to that of the varieties already described.

Olivine.-The olivine forms xenomorphic to hypautomorphic grains 1 to 2 millimeters in diameter. It possesses a very poor pinnacoidal clevage. Its age relation to the other minerals is the same as that of the bronzite in the norite phase, viz, some grains are older and some younger than the adjacent feldspar grains; it is distinctly older than both diallage and ilmenite, being partly or wholly surrounded by these minerals.

The alteration of the olivine has developed excellent though narrow reaction rims of green to pale-brown fibrous hornblende along feldspar contacts. The hornblende rim is accompanied by an inner zone of minute, brightly polarizing grains, which are seen under high power to possess the micaceous form of talc. These rims in some specimens are separated by a middle rim of minute magnetite grains; in others the magnetite forms the innermost rim or is not present. Magnetite and talc are scattered in varying amounts throughout the olivine grains, especially along cracks, and have practically replaced a few grains. In two thin sections of thoroughly uralitized rock, the outlines of the uralitic areas with rims of radiating needles suggest the former presence of olivine, but no evidence of talc, secondary magnetite, or serpentine was seen. It is therefore possible that in the more metamorphosed places olivine has, by reaction with feldspar, been completely changed to amphibole and that talc is developed only in practically undeformed rock. In this case olivine may have been widely distributed in the original gabbro, but careful search of a number of thin sections indicates a very small occurrence.

Diallage.-The diallage is identical to that of the porphyritic type in every particular save abundance, and in the amount of alteration to brown hornblende. It must originally have comprised 12 to 13 per cent of the rock, but more than half of it has been replaced by the hornblende. The latter preserves well the poikilitic texture, but not necessarily the exact orientation of the diallage. The section that contains the best development of the hornblende shows quite as little actual mechanical deformation as any other sẹction studiẹd, if not less than any.

$13338^{\circ}-$ Bull, $492-12-7$ 
Ilmenite.-Ilmenite is limited to a few distinctly poikilitic areas, chiefly intergrown with diallage (or brown hornblende), and to a less extent inclosing olivine and feldspar. This section affords the best example, in the whole series studied, of the relations of ilmenite to the other primary minerals. (See Pl. XII, B.)

CHEMICAI COMPOSITION.

No chemical analysis of the olivine gabbro was made, but comparison of its mineral volume percentages with those of the norite shows the minerals in the same proportions, except that the orthosilicate olivine is substituted for the metasilicate bronzite. Both represent extra high magnesia with respect to $\mathrm{CaO}$ available for pyroxene, but that occurring nearer to the quartz-hornblende phase is the higher in silica.

PYROXENITE PHASE.

The pyroxenite was collected on the south slope of the hill half a mile west of Bay Mountain. It comprises a small; partly concealed area several yards in diameter and grades rapidly into the main type. No evidence suggestive of intrusive nature was seen. The pyroxenite is cut by small basic pegmatite dikes composed chiefly of plagioclase.

\section{MEGASCOPIC CHARACTERS.}

The texture is medium grained and ophitic. The color is nearly black, mottled on weathered surfaces by the subordinate bleached feldspar. Ilmenite and pyrite are very prominent.

\section{MICROSCOPIC CHARACTERS.}

Mineral structure.-The microscopic texture is medium hypautomorphic granular and is ophitic where the feldspar is most prominent. The minerals, both primary and secondary, are the same as in the main type, differing only in volume percentages. Diallage comprises 65 per cent, ilmenite with subordinate pyrite 18 to 20 per cent, and labradorite 15 to 18 per cent. Brown hornblende is the most prominent of the secondary minerals ( 2 to 3 per cent), and some uralite fibers are developed in the diallage. Epidote, zoisite, and chlorite are scarce, being chiefly confined to minute veinlets.

Diallage.-The diallage forms hypautomorphic prisms 2 to 3 millimeters long, too small to present marked poikilitic character though distinctly younger than the feldspar.

Ilmenite. - The ilmenite grains are not uncommonly well over 1 millimeter long. They are xenomorphic, chiefly filling interstices between diallage grains, and are sufficiently abundant to suggest strongly a poikilitic texture. (See Pl. XII, $\cdot A$.) Several grains are included in diallage, and mostly show the same outlines as does the 


\section{PLATE XII.}




\section{PLATE XII.}

A. Photomicrograph of pyroxenite, showing the relation between diallage and ilmenite. The latter is interstitial and incloses an occasional diallage grain. The white clouded areas are slightly altered feldspar. Magnified 30 diameters. Without crossed nicols. Section 54.

$B$. Photomicrograph of olivine gabbro. The poikilitic character of ilmenite is especially well shown. Its contacts with adjacent and inclosed feldspar $(l)$ are marked by rims of brown hornblende. The olivine $(o)$ also has rims of brown hornblende along its contacts with feldspar. Within this rim is a second (white) rim of talc, followed by a third rim of magnetite. No diallage appears in the field. Magnified 50 diameters. Nicols crossed. Section 55. 


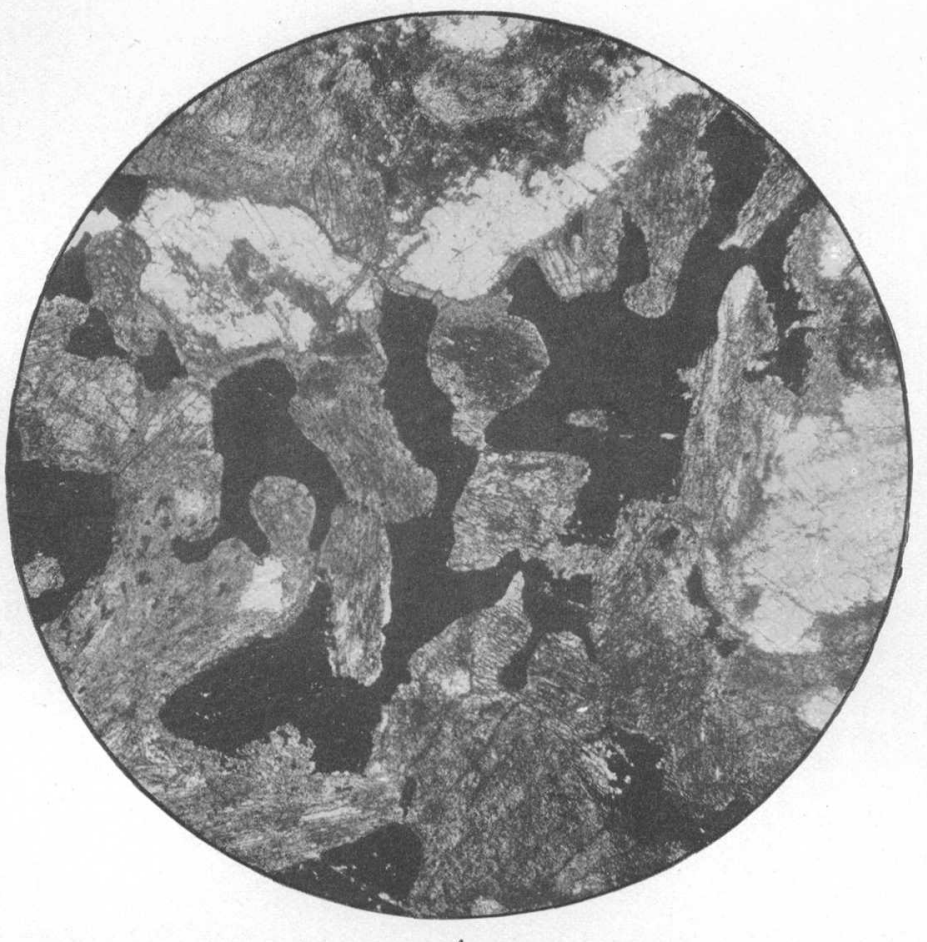

A

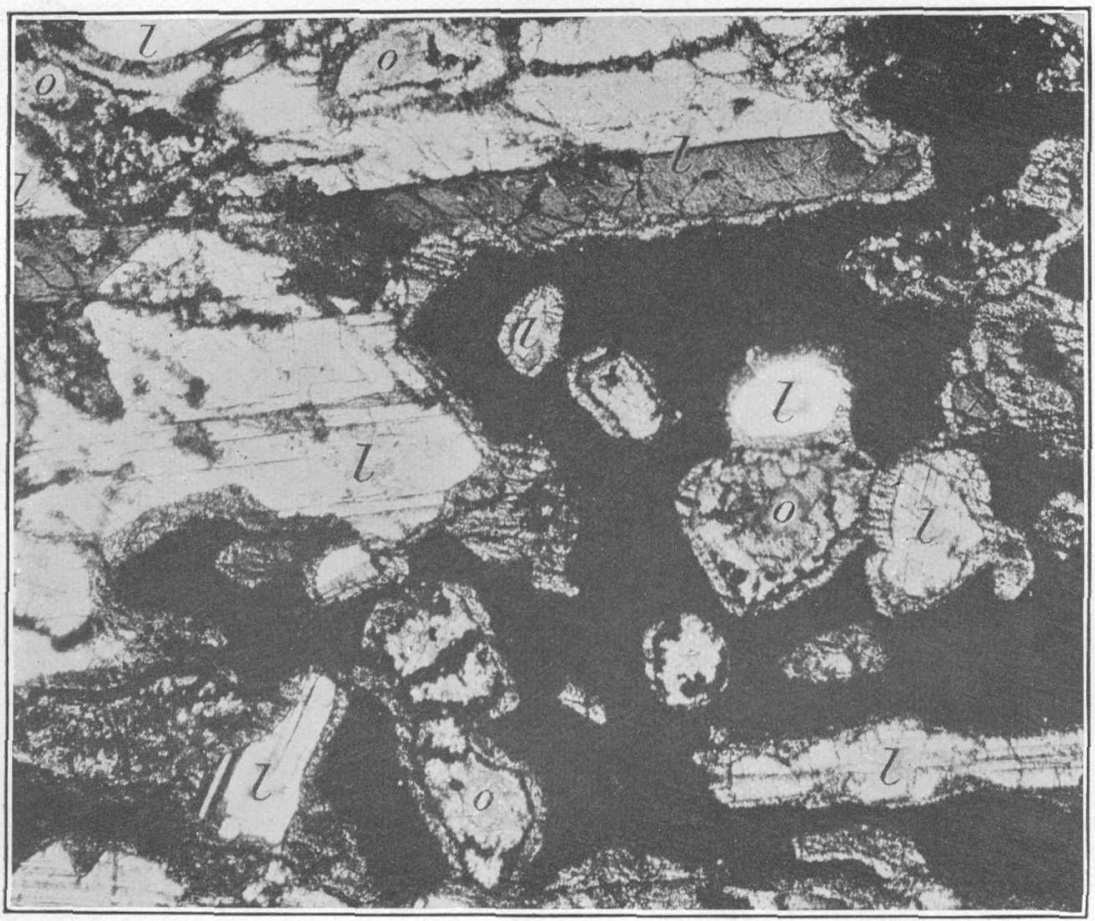


quartz in micropegmatite, though a few approach euhedral outlines. The crystallization therefore of the two minerals were in part synchronous, though that of the ilmenite was chiefly the later. Several grains are cut by veinlets of chlorite and epidote.

Pyrite.-The pyrite is generally similar in character to the ilmenite, though not sufficiently abundant to show beyond a doubt its relative age. Very few pyrite and ilmenite grains are in contact; if they are the ilmenite tends partly to surround the pyrite.

Labradorite.-The feldspar is identical with that of the porphyritic type.

Brown hornblende.-The poikilitic tendency of the secondary brown hornblende is especially well indicated in thin section (Pl. XII, $B$ ). It presents typical characters.

CHEMICAL COMPOSITION.

No chemical analysis of the pyroxenite phase was made. The mineral percentages and geologic occurrence indicate a local splitting of the main magma into two complementary parts, one ferromagnesian and high in metallic minerals, the other feldspathic, forming intrusive dikes into the first.

\section{BASIC PEGMATITE PHASE.}

The basic pegmatite forms local dikes and segregations measuring a few feet. The best exposures lie in the hilly land between Bay Mountain on the east and Broad Brook on the west. The mineral composition is chiefly labradorite and hornblende. The metallic minerals are not conspicuous. Minute, clear, red garnets are scattered through many of the feldspar grains. Both the dikes and segregations as a rule consist of equal portions of hornblende and feldspar, but contain many patches of almost pure feldspar or hornblende.

\section{LOCAL DLABASE DIKES.}

The observed exposures of diabase dikes are confined to the same small area as are those of the basic pegmatite. The dikes are very short and traverse the rock in numerous directions, forming a network. They cut the basic pegmatite and are clearly the youngest rock in the area.

\section{MEGASCOPIC CHARACTERS.}

The texture is medium grained and distinctly ophitic. The color is greenish black, mottled by purple feldspar. The exposures afforded no opportunity for collecting very fresh material.

\section{MICROSCOPIC CHARACTERS.}

The microscopic texture is markedly ophitic, though fine grained. The minerals present are fibrous to compact uralite (after diallage) much altered to chlorite (over 50 per cent), labradorite, saussuritized 
and kaolinized (about 45 per cent), ilmenite and pyrite, both con siderably oxidized (about 2 per cent). The general characters of the rock and of the individual minerals are the same as those of the main gabbro type. The only difference is the greater amount of chemical alteration, especially chloritization, in the diabase.

It is concluded from this similarity in composition and texture, together with the limitation and mode of occurrence of the diabase, that the upper portion of the main gabbro magma consolidated and became ruptured while the lower portion was still fluid, and that the latter welled upward into the resulting network of fissures, forming the dikes.

QUARTZ-HORNBLENDE GABBRO (AUVERGNOSE).

NORMaL PHASE.

Quartz-hornblende gabbro is.typically developed where the road forks eastward $1 \frac{1}{2}$ miles east of Preston. It is also well developed on Prentice Mountain, where its structural relation to the schistose hornfels is clearly shown.

\section{MEGASCOPIC CHARACTERS}

The color of the rock is the dark speckled gray typical of diorites. The texture in the massive portions is medium to coarse hypautomorphic-granular and is distinctly ophitic. Much of the rock, however, if not the greater part, has a distinct foliated tendency, varying - from slightly gneissic to highly schistose. The foliation strikes either north-south or about $\mathrm{N}$ : $45^{\circ} \mathrm{E}$., and is clearly. due to dynamic metamorphism and not to flowage or the magma during crystallization. The position of the rock along the western periphery of the whole gabbro mass accounts for the widespread development of the foliation. Much of the more highly schistose rock presents a pseudoporphyritic appearance, rounded feldspar fragments being surrounded by black bisilicates. The chief minerals are white to very pale purplish plagioclase and compact black hornblende. These two minerals are about equally abundant and comprise 80 to over 90 per cent of the rock. The other visible minerals are quartz (2-10 per cent), biotite (2-5 per cent), and ilmenite and pyrite (2-4 per cent).

Small veins of epidote, of chlorite, and especially of quartz are common, the presence of quartz veins serving to distinguish between the quartz-hornblende and the porphyritic diallage varieties. The foliated rock as a whole is more noticeably altered than the porphyritic gabbro, but the alteration products are not uniformly distributed.

MICROSCOPIC CHARACTERS.

Mineral structure.-The microscopic texture is the same as the megascopic-ophitic to granular in the massive and pseudoporphyritic to typically schistose in the sheared rock. The average minerals 
PLATE XIII. 


\section{PLATE XIII.}

A. Photomicrograph of quartz-hornblende gabbro, showing primary twinned augite (a) with partial (obscure) rims of green hornblende (h); primary biotite $(b)$ intergrown with augite; automorphic labradorite $(l)$; primary quartz $(q)$, with undulatory extinction, interstitial and intergrown with augite, biotite, and labradorite. The dark areas are chiefly green hornblende with remnants of augite. Magnified 30 diameters. Nicols crossed. Section 36.

$B$. Photomicrograph of hornblende crystals in quartz-hornblende gabbro. The rims are compact, but the interiors are sprinkled with quartz. Magnified about 100 diameters. Without crossed nicols. Section 19.

104 


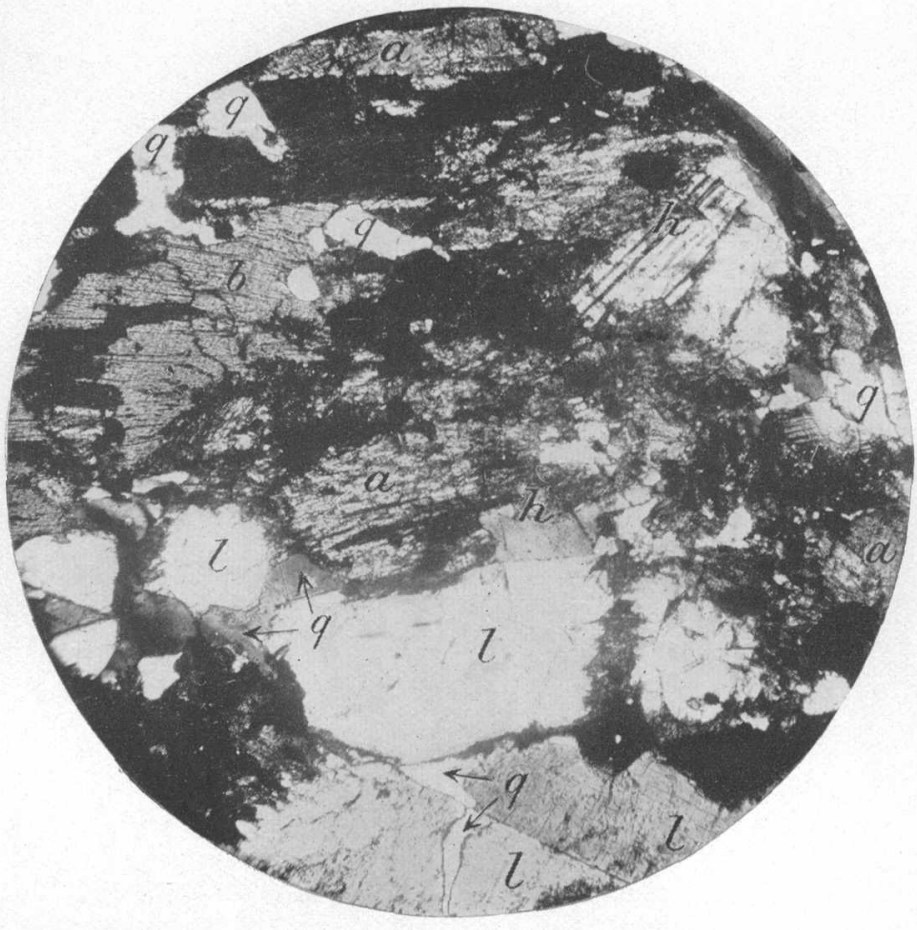

A.

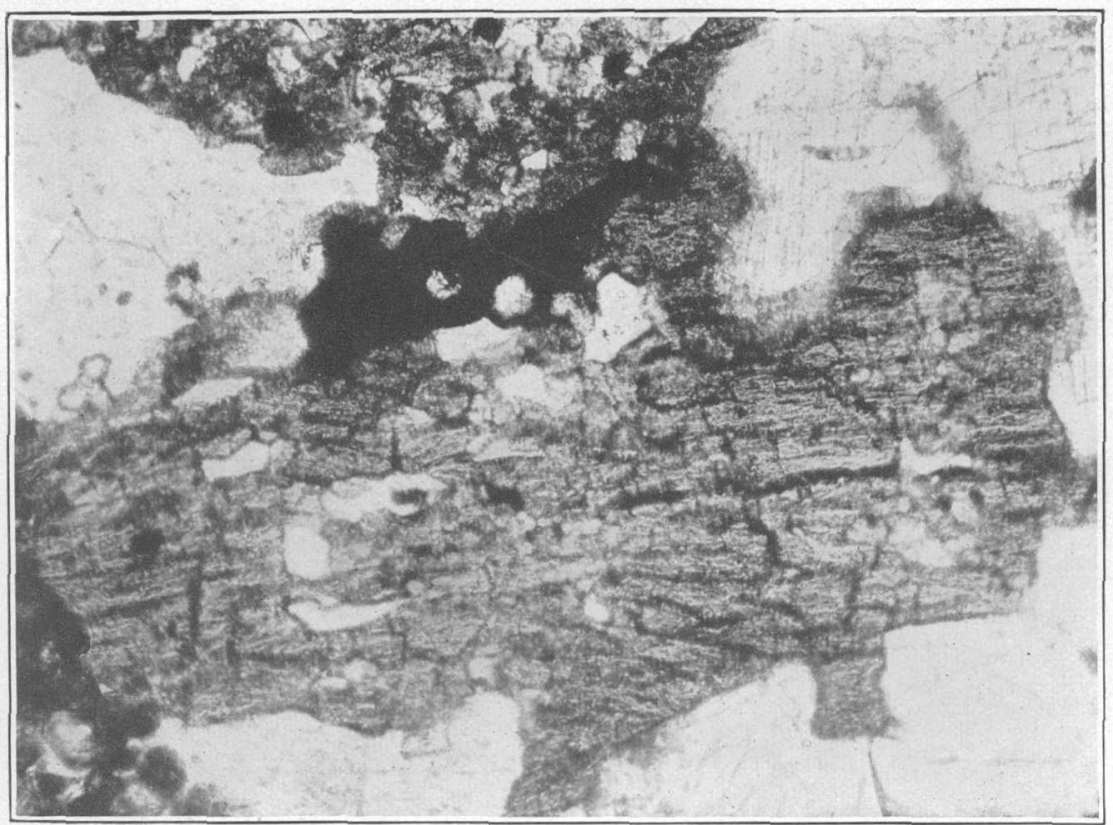


present are labradorite (45 per cent), hornblende with some augite (41 per cent), quartz ( 6 per cent), ilmenite and pyrite ( 5 per cent), biotite (2 per cent), apatite ( 0.5 per cent), and zircon (very scarce). The chief alteration products, which vary from almost nothing in some sections to more than a two-thirds replacement in others, are epidote, zoisite, albite-oligoclase, chlorite, muscovite and sericite, and quartz. Their modes of occurrence are the same as in the porphyritic gabbro, save that muscovite may be derived from biotite. A few minute, well-formed garnet crystals are present in fresh feldspar and are of doubtful origin. Calcite and kaolin are present as products of superficial weathering.

Labradorite.-The feldspar is mostly labradorite $\left(\mathrm{Ab}_{1} \mathrm{An}_{1}\right)$, though some sections contain basic andesine. The grains are lath shaped, mostly 2 to 4 millimeters long, and distinctly the oldest of the minerals. Zonal growth, though not very distinct, is characteristic. The outer zones generally have a higher birefringence and are somewhat more basic than the inner. Undulatory extinction and pericline twinning are common, and some grains are bent. As deformation becomes more and more marked, the grains become broken and separated by uralite veinlets, and are finally reduced to a rather finely granular state, the uralite veinlets making the schistosity more pronounced. Inclusions of minute hornblende needles are abundant in many sections, but the ilmenite-dust inclusions are not as numerous as in the feldspar of the porphyritic gabbro and are confined principally to the inner zones. Alteration to sericite is more prominent than in the previously described varieties and increases with the development of schistosity.

Augite.-The few pyroxene remnants, present only in undisturbed rock, have more the characters of augite than of diallage. They are present in a few specimens only, forming in one 6 per cent of the rock. Twinning lamellæ are present in all clear occurrences, and the best example shows intergrowths with biotite flakes. The augite forms inner cores surrounded by compact green hornblende, which may be primary or secondary. The general freedom from deformation in this section and the absence of fibrous uralite suggest a primary origin, but the character of the hornblende in other sections is suggestive of a secondary one. The crystallization of the augite was probably later than that of the feldspar. (See Pl. XIII, A.)

Hornblende.-The hornblende, which is of the common green variety, occurs either in single compact grains or more commonly in aggregates. Though mostly possessing the outline of compact, xenomorphic grains, it is largely made up of an interior of uralite and secondary quartz. (See Pl. XIII, B.) This interior is most conspicuous in sections showing moderate dynamic metamorphism. All gradations exist from grains with this mixed interior to truly compact 
grains. Black dusty inclusions are frequently present. The compact hornblende may be primary, as noted in the preceding paragraph. The quartz-uralite interiors recall the moderately metamorphosed examples of the porphyritic gabbro and are practically identical with an occurrence described and figured by G. H. Williams in the gabbro-diorite of the Baltimore region. ${ }^{1}$ The quartz is not a constant accompaniment of the uralite. In the quartz-hornblende gabbro it may have resulted from the recrystallization of original quartz inclusions in augite (see below), but in the porphyritic gabbro, as well as in the Baltimore occurrence, no original quartz was found. The secondary quartz appears to be an irregular accompaniment of uralitization.

The compact character of the hornblende together with the massive, ophitic texture of the rock was at first regarded as evidence of primary hornblende, but study of a large number of thin sections has forced the conclusion that much or most of the hornblende is of uralitic nature and is secondary after augite. The process of change, however, is not nearly so clear as in the porphyritic gabbro. With increase of dynamic action the hornblende has become drawn out. It is very possible that primary hornblende during metamorphism became granulated and recrystallized, assuming a somewhat uralitized appearance. Simple recrystallization, however, would not account for the secondary quartz above noted save as remnants of primary quartz grains. It is therefore possible, if not probable, that both primary and secondary hornblende are now present. In the extreme schistose forms the hornblende has recrystallized into linear aggregates of compact grains, and the rock assumes practically the same aspect as the equivalent form of the porphyritic rock. No brown hornblende was noted.

Quartz.-The quartz forms irregularly distributed anhedral grains rarely over 1 millimeter in diameter, and ranges from less than 2 or 3 to 12 per cent. The grains occur largely in interstices among those of feldspar, augite, or hornblende, and are clearly the youngest of all. They are included in much of the feldspar forming micropegmatite, and show exactly the same relation to the augite and compact hornblende. (See Pl. XIII, A.) Pressure effects are every where prominent, varying from pronounced undulatory extinction in the least affected places, through a typical flaser structure, to finely granulated flattened lenses where the schistose structure is strongly developed. The strained or granulated primary quartz in relatively large grains is very easily distinguished from the clear, unstrained, mirute granules of secondary quartz in the hornblende. The possible derivation of the secondary quartz in uralite hornblende from the primary quartz has already been mentioned. 
Ilmenite and pyrite.-The amount of the two metallic minerals, ilmenite and pyrite, in the quartz-hornblende gabbro ranges from less than 2 up to 8 per cent (average 5 per cent). The pyrite is in places as prominent as the magnetite, but is irregularly distributed. It commonly presents a partial crystal outline, but also shows anhedral contacts against the other minerals. Anhedral forms of the ilmenite are quite as characteristic as in the varieties previously described. It is clearly younger than all the silicates, but its relation to quartz is doubtful. Both are anhedral where in contact. In one slide a grain of quartz almost completely surrounded one of ilmenite; in another the narrow part of a roughly dumb-bell shaped grain of ilmenite extended through a grain of undulatory extinguishing quartz. The two minerals were evidently synchronous in crystallization. This relation is striking, in view of the fact that ilmenite and other primary metallic minerals are generally regarded as having crystallized first and quartz last in rocks containing both of these minerals.

Biotite.-Biotite in the quartz-hornblende gabbro varies from almost nothing up to over 5 per cent. In places, especially in narrow apophyses, where the rock grades toward an oligoclase granite, the biotite becomes more prominent than the hornblende. In the typical rock it is generally in small, unbent flakes less than 1 millimeter long, associated with hornblende. Some are evidently primary, others clearly secondary, a not uncommon occurrence in metamorphosed gabbroic rocks. The occurrence as an included tablet in fresh augite, proving a primary origin, has already been mentioned. Biotite also occurs in broad tablets, fully 1 millimeter square, in contact with or penetrating plagioclase. In both slides where this occurrence was noted, the rock was distinctly, though not greatly, mashed, and original biotite may have recrystallized or secondary biotite developed. It seems independent of the hornblende, and its primary character seems the more likely. The increase of biotite as the rock grades toward oligoclase granite also speaks for its primary origin, though it does not argue against the probable secondary origin of many small flakes distributed along the cleavage and borders of hornblende. Besides altering to chlorite, the biotite, especially in the gradations mentioned, may be partly altered to, or intergrown with, muscovite.

Apatite.-Apatite tends to form long, needle-like prisms up to 1 millimeter in length, included in feldspar, hornblende, and ilmenite. Some are broken by minute faults. Though occurring only in microscopic crystals and never constituting as much as 1 per cent of the rock, they are everywhere present and constitute the distinguishing characteristics between the quartz-hornblende and the porphyritic gabbros. 
The classification of the quartz-hornblende gabbro according to prevailing systems is indefinite. Mineralogically it is a quartz diorite, but the chemical analyses (p. 114) shows it to belong clearly to the gabbros. To judge from its probable most prominent original mincrals-labradorite, augite-hornblende (?), and quartz-it was formerly a quartz diabase or quartz gabbro. Its present state is best indicated by the term quartz-hornblende gabbro, or quartz gabbro-diorite. According to the quantitive system, the rock falls close to the norite, Class II, order 5, rang 4, subrang 3 -that is, auvergnose.

RELATION OF QUARTZ-HORNBLENDE GABBRO TO PORPHYRITIC GABBRO.

Although the drift covering prevents the actual following of the quartz-hornblende gabbro into the porphyritic gabbro, specimens collected along the eastern edge of the former's area show convincing microscopic evidence of gradation. Though the megascopic appearance of these and their content of microscopic apatite would class them with the quartz-hornblende gabbro, their nicroscopic texture, in some specimens poikilitic and in others like that of the norite, their paucity or total lack of biotite and primary quartz, and the occurrence in them of some diallage, indicate marked association with the porphyritic gabbro. These two principal varieties are therefore believed to have been segregated from one magma after intrusion.

DIALLAGE GABBRO SEGREGATIONS.

Small, rounded, fine-grained segregations 1 to 3 inches in diameter are of rather common occurrence in the quartz-hornblende gabbro. Though insignificant in size, they are of interest in that their original mineral composition and microtexture is the same as that of the porphyritic gabbro. . They serve still further to indicate the relation between the two principal varieties.

QUARTZ ANORTHOSITE AND QUARTZ HORNBLENDITE.

The minerals of the quartz-hornblende gabbro have in a few places been segregated into patches, forming small local intrusions of almost pure labradorite and quartz on the one hand and of almost pure hornblende on the other. The first of these varieties consists of 85 to 90 per cent of labradorite $\left(\mathrm{Ab}_{1} \mathrm{An}_{7}\right)$ and 10 to 15 per cent of quartz. A few small grains of common green hornblende and some apatite crystals comprise the accessories. No metallic minerals were seen in thin section. One specimen collected from a small outlying sheet is very free from crushing effects. The labradorite has remarkably well-developed Carlsbad, albite, and pericline twinning. The quartz is undoubtedly primary and holds the same interstitial and micropegmatitic relations as in the normal quartz-hornblende gabbro. As rock consisting essentially of labradorite is 
termed anorthosite, this occurrence may be called quartz anorthosite. The hornblendite segregations contain a very little labradorite and interstitial quartz. The hornblende comprises over 90 per cent of the rock, is compact, free from marked pressure effects, and shows no evidence whatever of derivation from pyroxene. It is green, with a slight brownish shade in thin section. This presence of undoubted primary hornblende further suggests that hornblende in the main body of the quartz-hornblende gabbro is in part original.

\section{BASIC PEGMATITE AND APLITE.}

Small dikes and patches of basic pegmatite bear the same relation to the quartz-hornblende gabbro as to the porphyritic gabbro. That associated with the quartz-hornblende variety is identical with it in mineral composition, though no microscopic determination of the feldspar was made. It differs from the other pegmatite in the white color of its feldspar and in the generally smaller size of its minerals.

The aplite ("aplite" is here used as a textural term) forms narrow, white, veinlike stringers in the normal rock. The microscope shows it to consist of plagioclase and a little quartz. Decomposition and poor orientation prevented accurate determination of the feldspar.

\section{OLIGOCLASE GRANITE (ALSBACHOSE).}

Oligoclase granite is limited to small intrusive sheets in the quartz schist of Barnes Hill and to small dikes and segregations in the quartz-hornblende gabbro on the small hill south of Prentice Mountain. Most of the occurrences are considerably weathered, but material fit for study can be found with some care.

MEGASCOPIC CHARACTERS.

The texture is rather fine grained, more or less gneissic, and subporphyritic. The color is nearly white, becoming a decided green in the more altered specimens. The visible minerals are chiefly feldspar, including scattered phenocrysts of plagioclase and quartz, with minor muscovite and biotite (or chlorite). Some garnets are visible in the Barnes Hill occurrences.

\section{MICROSCOPIC CHARACTERS.}

Mineral structure.-Under the microscope the phenocrysts are hypautomorphic, 2 to 3 millimeters long, and constitute about 5 per cent of the rock; the groundmass minerals are mostly xenomorphic, due in part to granulation and in part to synchronous crystallization. They are oligoclase (53 per cent), quartz (33 per cent), muscovite and biotite ( 10 per cent), ilmenite ( 2 per cent), garnet, and a few minute grains of titanite, apatite, and zircon (1 to 2 per cent). Chlorite is the most prominent alteration product and may replace all the biotite. Epidote, zoisite, and sericite are also present in varying amounts, 
Oligoclase.-Both the phenocrysts and groundmass feldspars are basic oligoclase $\left(\mathrm{Ab}_{7} \mathrm{An}_{3}\right)$. The phenocrysts are rectangular in outline, show Carlsbad, albite, and pericline twinning, and in some cases have been somewhat bent. A suggestion of Baveno twinning appears in a very few specimens. The grains in the groundmass are generally less than 1 millimeter long, xenomorphic, and show but little crushing effect. Slight alteration to epidote, zoisite, and sericite, or even to distinct tablets of muscovite, is characteristic. No potash feldspar could be identified, though the amount of $\mathrm{K}_{2} \mathrm{O}$ in the analysis is high for the amount of mica noted.

Quartz.-Quartz forms irregular grains up to 1 millimeter or more in diameter. It invariably shows marked crushing effect, from strong undulatory extinction to moderate granulation. It maintains the same interstitial and micropegmatitic relation to the feldspar as in the quartz-hornblende gabbro.

Mica.-Muscovite and biotite vary in their relative proportions. In the material analyzed (from a small sheet on Barnes Hill) the ratio of muscovite to biotite is 2 to 1 ; in the small dikes south of Prentice Mountain muscovite occurs only as minor intergrowths with chlorite after biotite. This latter case suggests that the muscovite may be secondary after biotite, but the muscovite in the former case is quite independent of biotite or chlorite and appears to be primary. Both micas form small tablets, which; in the more crushed occurrences, are smeared out into streaks wrapping around the feldspar and quartz.

Ilmenite.-The black, metallic grains are less than 5 millimeters in diameter and for the most part are hypautomorphic. Their outlines suggest both magnetite and ilmenite, as does the chemical analysis (p. 114). The xenomorphic character, so conspicuous in the gabbros, is not noticeable, owing perhaps to the small amount and size of the grains. No pyrite was noted in thin section, but some grains were noted in the field.

Other minerals.-Garnet occurs in typical rounded grains up to 1.5 millimeters in diameter, containing inclusions of quartz and, in some specimens, of biotite. It is more or less altered to chlorite. Titanite forms very small anhedral to wedge-shaped grains. It frequently surrounds ilmenite grains, and is especially conspicuous in the more schistose occurrences, in which the ilmenite is most scarce. These facts tend to class it wholly as secondary (leucoxene). Apatite and zircon form minute, euhedral crystals typical of granitic rocks.

CLASSIFICATION.

According to the prevailing systems, this rock falls between the granite and quartz-diorite groups. The absence of alkalic feldspar distinguishes it from common granite and most granodiorite; still, the appearances in the field, as well as the chemical composition, are 
so like those of granite that the name "oligoclase granite" seems as fitting as any. Under the quantitative system the rock falls in Class I, order 3, rang 2, subrang 4-that is, alsbachose.

RELATION OF OLIGOCLASE GRANITE TO QUARTZ-HORNBLENDE GABBRO.

Field, microscopic, and chemical evidence all combine to prove a close gradational relationship between the oligoclase granite and the quartz-hornblende gabbro. At the top of the north spur of Prentice Mountain the latter rock becomes more feldspathic and quartzose as the hornfels cover is approached. The narrow apophyses, or stringers, in the hornfels are almost free from black minerals. The increase of biotite and decrease of hornblende is not so clearly marked save in thin section. A thin section of one of these apophyses (No. 70) shows less quartz and more feldspar and biotite than the material analyzed, but it was from a point much nearer to the main mass. Intermediate rock occurs at various points near contacts, both of the main area and of outliers. The gradational character of the rock at Prentice Mountain is shown in the following table:

Mineral composition of rocks near Prentice Mountain.

\begin{tabular}{|c|c|c|c|c|c|c|c|c|}
\hline \multirow[b]{2}{*}{ Rock. } & \multirow{2}{*}{ 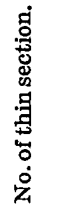 } & \multirow[b]{2}{*}{ Location. } & \multicolumn{6}{|c|}{ A pproximate composition (per cent). } \\
\hline & & & Feldspar. & 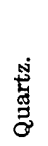 & 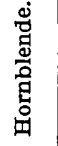 & 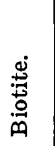 & 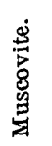 & 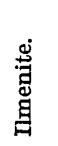 \\
\hline Typical quartz-hornblende & 3 & 1 mile east of Pres- & $A b_{1} A n_{1}, 4$ & 6 & 41 & 2 & 0 & 5 \\
\hline $\begin{array}{l}\text { Intermediate; probable } \\
\text { segregation in gabbro. }\end{array}$ & 21 & $\begin{array}{l}\mathrm{R} \text { oad s o u th of } \\
\text { Prentice Moun- }\end{array}$ & $\mathrm{Ab}_{7} \mathrm{An}_{3}, 65 \ldots$ & 8 & 18 & 5 & 0 & 2 \\
\hline $\begin{array}{l}\text { Intermediate; near contact } \\
\text { of main mass with horn- } \\
\text { fels. }\end{array}$ & 34 & $\begin{array}{l}\text { Prentice Mou n- } \\
\text { tain, northeast } \\
\text { spur. }\end{array}$ & $\mathrm{Ab}_{7} \mathrm{An}_{3}, 66$ & 14 & 13 & 1 & 0 & 4 \\
\hline $\begin{array}{l}\text { Intermediate; stringer - in } \\
\text { hornfels above contact. }\end{array}$ & 70 & ....do............... & $A b_{7} \Lambda n_{8}, 68$ & 13 & 0 & 13 & 2 & 1.5 \\
\hline $\begin{array}{l}\text { Oligoclase gran it e; thin } \\
\text { sheet in hornfels. }\end{array}$ & 77 & $\begin{array}{l}\text { North end of } \\
\text { Barnes Hill. }\end{array}$ & $\mathrm{Ab}_{7} \mathrm{An}_{8}, 53 \ldots$ & 33 & 0 & 3 & 7 & 1.0 \\
\hline $\begin{array}{l}\text { Oligoclase granite; small } \\
\text { dike in quartz-horn- } \\
\text { blende gabbro. }\end{array}$ & 78 & $\begin{array}{l}\text { Fill just south of } \\
\text { Prentice Moun- } \\
\text { tain. }\end{array}$ & $\mathrm{Ab}_{7} \mathrm{An}_{3}, 52 \ldots$ & 39 & 0 & $a .8$ & 0 & 1.0 \\
\hline
\end{tabular}

$a$ Chlorite after biotite, save one possible grain which has outline suggesting hornblende.

The gradation is marked first by increase in quantity and acidity of feldspar, increase of quartz and biotite, and decrease of hornblende; finally by further great increase of quartz at the expense of the other minerals and total disappearance of hornblende in favor of biotite, which in turn may give way to muscovite.

The chemical analyses of the two extremes agree with the microscopic evidence. Comparison of Nos. 2 and $2 \mathrm{~d}$, on page 114, shows a marked increase in the latter of $\mathrm{SiO}_{2}, \mathrm{Na}_{2} \mathrm{O}$, and $\mathrm{K}_{2} \mathrm{O}$ and a loss of $\mathrm{Fe}_{2} \mathrm{O}_{3}, \mathrm{FeO}, \mathrm{MgO}, \mathrm{CaO}$, and $\mathrm{TiO}_{2}$; the predominance of $\mathrm{Na}_{2} \mathrm{O}$ over $\mathrm{K}_{2} \mathrm{O}$ is a feature in common to both the rocks as well as to all the gabbro series. 


\section{OUTLIERS.}

GABBRO.

Specimens and study of thin sections from the outliers class that of Ayer Hill with the porphyritic gabbro (No. 1). Erosion may possibly have removed a thin upper quartzose portion. The western outliers contain a few remnants of diallage and are generally similar to the gradation rock between the porphyritic and quartz-hornblende gabbros described on page 108. They also contain a little free'quartz near their western or upper contacts and in apophyses and may thus be regarded as similar to the upper portion of the main mass. The smaller outliers are of the same character as those just mentioned.

\section{AMPHIBOLITE SHEETS.}

As previously stated (p. 62), the name "amphibolite" for convenience is restricted in this bulletin to intrusive sheets, and "hornblende schist" is used to designate chemically similar rocks belonging to the metamorphic sedimentary series.

MEGASCOPIC CHARACTERS.

The amphibolite sheets vary in thickness from a few inches to several feet. They also vary in grain and texture. The thinner ones are fine, even grained, highly schistose, and generally similar to the hornblende schist; the thicker ones are less schistose and resemble the markedly, but not the extremely, sheared portions of the gabbro mass. Hornblende phenocrysts are present in some of the coarsergrained sheets.

The megascopic minerals are chiefly feldspar and hornblende, with small amounts of biotite and ilmenite. Primary quartz is absent, but the glassy character of the fine-grained feldspar, where broken across the cleavage, may easily cause them to be mistaken for quartz.

\section{MICROSCOPIC CHARACTERS.}

Mineral structure.-The microscopic texture is schistose and wholly xenomorphic, the principal minerals, feldspar and hornblende, each forming lenticular aggregates mostly 2 to 4 millimeters long, and even longer in the coarser-grained specimens. The primary minerals are hornblende ( 50 to 55 per cent), labradorite ( 40 to 45 per cent), biotite ( 2 to 5 per cent), ilmenite and titanite ( 2 to 4 per cent), apatite (less than 1 per cent); the secondary minerals are epidote, zoisite, sericite, rutile, calcite, and ferric oxide.

The latter vary in amount, but in the seven sections studied comprise but a very slight percentage. Their modes of occurrence are the same as in the other members of the gabbro series.

Hornblende.-Hornblende is in most cases the common green variety, forming aggregates of compact grains along the schistosity, 
In one of the coarser-grained examples (sec. No. 66) it is uralite and presents the same characters as the more, but not most, schistose occurrences in the porphyritic gabbro mass. In another section the hornblende is the brown variety, forming large aggregates or "augen" (10 millimeters long) of compact grains. Single grains range up to 5 millimeters in length. One of these aggregates is dislocated and drawn out along a microscopic shear plane, and clearly antedates the period of dynamic metamorphism. It may have been a primary phenocryst or may have been derived by replacement of diallage phenocrysts (p. s0). Granulated inclusions of feldspar suggest a former poikilitic texture. The brown hornblende is partly bleached and altered to small brown biotite flakes uniformly oriented.

Labradorite.-Labradorite $\left(\mathrm{Ab}_{1} \mathrm{An}_{1}\right)$ forms finely granular aggregates among the hornblendes. Single grains average 0.3 millimeter in diameter. Twinning striæ are absent in many grains. The feldspar areas include many fine granules of compact hornblende, no doubt the final development of the uralite, which was seen to penetrate the broken feldspar in moderately mashed portions of the gabbros. Small granules of the feldspar are also isolated in the hornblende areas. They are largely unstriated and may at first be mistaken for quartz. The smallest ones especially are doubtful, but, save in one thin section, the only quartz positively identified occurs in veinlets and must be classed as secondary. The exception is from a lenticular sheet close to the road running eastward from Preston and about 600 feet west of the quartz-hornblende gabbro contact. It resembles the latter rock in composition.

Other minerals.-Biotite forms flakes and tablets generally less than 5 millimeters long, mostly associated with hornblende. Some of it is clearly secondary, some of doubtful origin. Some basal sections show minute sagenite twins of rutile needles. Ilmenite forms irregular, but generally flattened, grains. A few preserve enough of the original outline to show the xenomorphic character so conspicuous in the gabbros. Several grains are surrounded by borders of titanite (leucoxene), and small clusters of titanite grains in some sections suggest the complete breaking down of the original ilmenite. Titanite is generally more conspicuous where the iron mineral is lacking, but both minerals in some sections are relatively prominent.

RELATIONS OF AMPHIBOLITE SHEETS. TO GABBRO TYPE.

The character of the hornblende in the coarser-grained amphibolite sheets, giving the impression that they originally contained diallage, and the general lack of quartz, correlate the amphibolites with the western outliers-intermediate between the porphyritic and the quartz-hornblende gabbros. The analyses, Nos. 3 and $3 \mathrm{a}$ in the 13338 - Bull. $492-12-8$ 
following table, are in some respects intermediate between those of the two gabbros (Nos. 1 and 3), but the differences between these latter are so small that any intermediate rock could be correlated with either. The low soda in No. $3 \mathrm{a}$ is accounted for in part by the kaolinized condition of the feldspar.

\section{DIFFERENTIATION OF MEMBERS OF THE PRESTON GABBRO.}

The chemical compositions with molecular ratios of the principal members of the Preston gabbro are given in the following table:

Chemical composition of members of the Preston gabbro.

\begin{tabular}{|c|c|c|c|c|c|c|}
\hline & 1. & $1 \mathrm{a}$. & 2. & 3. & 3a. & $2 \mathrm{~d}$. \\
\hline $\mathrm{SiO}_{2} \ldots$ & $\begin{array}{l}45.17 \\
.753\end{array}$ & $\begin{array}{c}49.98 \\
.833\end{array}$ & \multirow{16}{*}{\begin{tabular}{c}
49.90 \\
.832 \\
14.64 \\
.143 \\
4.65 \\
.029 \\
7.52 \\
.104 \\
6.06 \\
.152 \\
9.14 \\
.163 \\
2.73 \\
.044 \\
.46 \\
.005 \\
1.98 \\
.46 \\
None. \\
\hdashline. .98 \\
1.98 \\
.025 \\
None. \\
.38 \\
.003 \\
.02 \\
.001 \\
.18 \\
.003 \\
.02 \\
.000
\end{tabular}} & 47.63 & 48.05 & 73.52 \\
\hline $\mathrm{Al}_{2} \mathrm{O}_{3}$ & $\begin{array}{c}17.18 \\
.169\end{array}$ & $\begin{array}{c}17.65 \\
.174\end{array}$ & & 15.49 & 10.17 & $\begin{array}{c}12.86 \\
.126\end{array}$ \\
\hline $\mathrm{Fe}_{2} \mathrm{O}_{3}$ & $\begin{array}{c}1.92 \\
.012\end{array}$ & $\begin{array}{c}3.48 \\
.022\end{array}$ & & 2.60 & 3.44 & $\begin{array}{c}1.48 \\
.009\end{array}$ \\
\hline $\mathrm{FeO}$ & $\begin{array}{l}7.88 \\
.110\end{array}$ & 4. 85 & & $\dddot{8.70}$ & 7.47 & 1.54 \\
\hline $\mathrm{MgO}$. & $\begin{array}{c}9.95 \\
249\end{array}$ & $\begin{array}{l}7.58 \\
.190\end{array}$ & & $\dddot{8.40}$ & 8.15 & $\begin{array}{l}.021 \\
.57 \\
014\end{array}$ \\
\hline $\mathrm{CaO}$. & $\begin{array}{c}8.93 \\
.160\end{array}$ & $\begin{array}{c}9.42 \\
.168\end{array}$ & & 10.04 & 10.85 & 2.08 \\
\hline $\mathrm{Na}_{2} \mathrm{O}$ & $\begin{array}{c}4.23 \\
.068\end{array}$ & $\begin{array}{c}2.75 \\
.045\end{array}$ & & 3.09 & $1.51^{\circ}$ & $\begin{array}{c}.000 \\
.070\end{array}$ \\
\hline $\mathrm{K}_{2} \mathrm{O}$. & $\begin{array}{l}.27 \\
.003\end{array}$ & $\begin{array}{l}.17 \\
.002\end{array}$ & & .36 & .92 & $\begin{array}{l}.41 \\
1.41\end{array}$ \\
\hline & $\begin{array}{c}2.18 \\
.27\end{array}$ & $\begin{array}{l}2.23 \\
1.06\end{array}$ & & $\begin{array}{r}1.78 \\
.36\end{array}$ & $\begin{array}{r}1.21 \\
.07\end{array}$ & $\begin{array}{l}1.21 \\
.35\end{array}$ \\
\hline $\mathrm{CO}_{3} \ldots$ & $\begin{array}{l}.21 \\
.005\end{array}$ & None. & & None. & None. & None. \\
\hline $\mathrm{TiO}_{2}$. & $\begin{array}{c}1.63 \\
.020\end{array}$ & $\begin{array}{l}.87 \\
.011\end{array}$ & & 1.93 & 1.67 & $\begin{array}{l}.51 \\
.006\end{array}$ \\
\hline $\mathrm{ZrO}_{2}$. & None. & None. & & None. & None. & None. \\
\hline $\mathrm{P}_{2} \mathrm{O}_{5} \ldots$ & None. & None. & & .11 & None. & .0 \\
\hline & $\begin{array}{l}.11 \\
.003\end{array}$ & Undet. & & indet. & Undet. & None. \\
\hline MnO. & $\begin{array}{l}.15 \\
.002\end{array}$ & $\begin{array}{l}.15 \\
.002\end{array}$ & & .22 & Undet. & .08 \\
\hline \multirow[t]{2}{*}{$\mathrm{BaO}}$. & $\begin{array}{l}\text { None. } \\
. . . . . .\end{array}$ & $\begin{array}{c}\text { None. } \\
\ldots . . . . .\end{array}$ & & None. & Undet. & .02 \\
\hline & 100.08 & 100.19 & 100.12 & 100.70 & 100.06 & 100.06 \\
\hline
\end{tabular}

1. Coarse-grained porphyritic gabbro; W. A. Drushel, analyst.

1a. Norite; George Steiger, analyst, United States Geological Survey.

2. Quartz-hornblende gabbro; George Steiger, analyst, United States Geological Survey.

3. Coarse-grained amphibolite; George Steiger, analyst, United States Geological Survey.

3a. Fine-grained amphibolite; G. F. Loughlin, analyst.

2d. Oligoclase-granite; George Steiger, analyst, United States Geological Survey.

Norms of the members of the Preston gabbro.

\begin{tabular}{|c|c|c|c|c|c|c|c|c|c|c|c|c|c|c|}
\hline & Q. & Or. & Ab. & An. & Neph. & Cor. & Diop. & Нур. & Ol. & Mt. & Ilm. & Ap. & $\mathrm{FeS}_{2}$ & Etc \\
\hline $\begin{array}{l}1 \\
1 \mathrm{a} \\
2 \\
2 \mathrm{~d}\end{array}$ & $\begin{array}{r}1.74 \\
5.34\end{array}$ & $\begin{array}{l}1.67 \\
1.11 \\
2.78\end{array}$ & $\begin{array}{l}19.39 \\
23.58 \\
23.06\end{array}$ & $\begin{array}{l}27.24 \\
35.31 \\
26.13\end{array}$ & 8.80 & & $\begin{array}{r}13.87 \\
9.05 \\
13.57\end{array}$ & $\begin{array}{l}19.53 \\
15.06\end{array}$ & 0.56 & $\begin{array}{l}2.78 \\
5.10 \\
6.73\end{array}$ & $\begin{array}{l}3.04 \\
1.67 \\
3.80\end{array}$ & & \begin{tabular}{c}
0.36 \\
\hdashline 32
\end{tabular} & \\
\hline $2 \mathrm{~d}$ & 37.44 & 8.34 & 36. & 9.73 & & 0.61 & & 2.32 & & 2.09 & 0.91 & 0.31 & & \\
\hline
\end{tabular}

No. 1, porphyritic gabbro, is surprisingly high in $\mathrm{Na}_{2} \mathrm{O}$ and $\mathrm{MgO}$ when compared to the mineral composition. The excess of $\mathrm{Na}_{2} \mathrm{O}$ is shown by the 8.80 per cent nephelite in the norm. Rocks in the same rang tabulated by $\mathrm{H}$. S. Washington ${ }^{1}$ are characterized by 
modal nephelite or analcite, but no such minerals were found either by optical or chemical tests in the porphyritic gabbro. Neither were any zeolites found. The only secondary sodic minerals detected were albite and scapolite, but the lime content of the latter and the association of both minerals with more abundant epidote and zoisite do not suggest so high a percentage of $\mathrm{Na}_{2} \mathrm{O}$ with respect to $\mathrm{CaO}$ or to $\mathrm{SiO}_{2}$. If the original feldspar $\left(\mathrm{Ab}_{3} \mathrm{An}_{4}\right)$ constitutes 50 per cent of the rock (a generous estimate), it accounts for but 2.45 per cent $\mathrm{Na}_{2} \mathrm{O}$. The total pyroxene and resulting pale-green uralite, judging from analyses of similar minerals, ${ }^{1}$ may account for 0.5 to 0.8 per cent of the remainder, leaving at least 1.70 per cent for secondary albite and scapolite. This would imply 14.4 per cent of albite or 11.6 of marialite, the pure soda scapolite. The sum of these minerals in sections showing the most alteration could not be positively estimated above 2 or 3 per cent. Owing to the coarse porphyritic grain of the rock a composite sample was selected, and special care was taken to avoid altered or metamorphosed material. Microscopic veinlets and replacements of albite were to be expected, but it is most improbable that they could have been numerous enough to account for so great an excess of soda. The excess remains unexplained.

The high $\mathrm{MgO}$ is expressed by the 20.56 per cent olivine in the norm. The 35 augites tabulated by Iddings ${ }^{2}$ contain without exception a distinctly higher percentage of $\mathrm{CaO}$ than of $\mathrm{MgO}$, but in this porphyritic gabbro only about 3 per cent of $\mathrm{CaO}$ against 9.95 per cent of $\mathrm{MgO}$ is available, after satisfying the 50 per cent feldspar, for the diallage, uralite, and the small amounts of epidote and zoisite. This excess of $\mathrm{MgO}$ is decidedly higher than that characteristic of hornblende. It can not be satisfactorily explained by the small amount of chlorite in the sample and must be regarded as an abnormally high constituent of the diallage.

The excess of $\mathrm{Al}_{2} \mathrm{O}_{3}$ (2.4 per cent) over that required by the feldspar is partly accounted for by the secondary minerals, but must belong mostly to the diallage and related uralite. The percentage of $\mathrm{Al}_{2} \mathrm{O}_{3}$ thus agrees with the optical properties in classing the diallage as augitic rather than diopsidic.

The other noteworthy features in No. 1 are the relatively low sum of the magnetite and ilmenite in the norm- 5.82 per cent, and the absence of apatite.

No. 1a differs from No. 1 in containing nearly 4.81 per cent more of $\mathrm{SiO}_{2}, 2.37$ less of $\mathrm{MgO}, 0.49$ more of $\mathrm{CaO}$, and 1.48 less of $\mathrm{Na}_{2} \mathrm{O}$. In spite of these differences in $\mathrm{CaO}$ and $\mathrm{Na}_{2} \mathrm{O}$, the feldspar of $\mathrm{No} .1 \mathrm{a}$ is more abundant and less basic in the thin section studied. In spite 
of the lower percentage of $\mathrm{MgO}$ and of its lower excess over the $\mathrm{CaO}$ available for pyroxenes, considerable bronzite (estimated at 22 per cent) is actually present, and here the norm with 19.50 per cent hypersthene agrees well with microscopic study. The diallage, then, is found to be higher in $\mathrm{CaO}$ than in $\mathrm{MgO}$, thus conforming to the average pyroxene. The nearly equal amounts of olivine in the norm of No. 1 and of hypersthene in that of 1.a suggest that the difference in $\mathrm{SiO}_{2}$ is the chief cause of the difference in mineral composition; but the absence of olivine in the mode of No. 1 would lead one to expect a more marked predominance of $\mathrm{MgO}$ over $\mathrm{CaO}$ in No. 1a than in No. 1, whereas the reverse is true. The higher magnetite in the norm of No. 1a is due in part to the presence of secondary $\mathrm{Fe}_{2} \mathrm{O}_{3}$, but the black metallic mineral appears more abundant in thin section. The absence of apatite is again noteworthy. The small amount of surplus $\mathrm{SiO}_{2}$ is due mostly, if not wholly, to secondary quartz.

No. 2 is characterized especially, in the norm as in the mode, by over 5 per cent of free quartz (a little less than estimated in thin section) and by an increase of $\mathrm{K}_{2} \mathrm{O}$-orthoclase in the norm and biotite in the mode. The feldspar, as in No. 1a, is $A b_{1} A n_{1}$, but the uniform percentages of the albite in the norms of $1 \mathrm{a}$ and 2 suggest a slightly more acidic character, as the feldspar here comprises but 45 per cent of the rock. The excess of $\mathrm{Na}_{2} \mathrm{O}$, however, over that in the modal feldspar, will only form about 0.4 per cent of the augite-hornblende, and conforms well with the average content in augite. The $\mathrm{Al}_{2} \mathrm{O}_{3}$ of No. 2 is lower than in Nos. 1 and 1a, but the excess of that demanded by the feldspar is enough to give the pyroxene or amphibole about 4.5 per cent $\mathrm{Al}_{2} \mathrm{O}_{3}$. These chemical characters thus agree with the optical, which are those of augite and common green hornblende. The MgO (6.06 per cent) is lower than in Nos. 1 and 1a, though still in excess of the $\mathrm{CaO}$ ( 4.5 per cent) available for the ferromagnesian minerals. These percentages show the $\mathrm{MgO}$, as in No. 1, to be high for an augitic though near the average for a hornblendic rock, but the differences in excess in these two analyses are very marked, as shown by the percentages of olivine and hypersthene in the norms.

Magnetite and ilmenite are decidedly more prominent than in No. 1 , as both the norm and the mode show. Apatite is conspicuous, forming nearly 1 per cent. Although a minor accessory, its general absence in thin sections of No. 1 and its constant presence in those of No. 2 are distinguishing features.

The increase in $\mathrm{K}_{2} \mathrm{O}$ and in the acidity of the feldspar commonly appear in rocks with the advent of the free quartz, and the segregation of $\mathrm{K}_{2} \mathrm{O}$ and $\mathrm{SiO}_{2}$ into the upper portion of the mass is normal; but the distinct segregation of the metallic minerals and apatite into the upper quartzose rock, with the tendency of $\mathrm{MgO}$ and $\mathrm{Na}_{z} \mathrm{O}$ (?) to segregate in the opposite direction, is striking. It is, however, 
somewhat analogous to the pegmatite type ${ }^{1}$ of magnetite ore in the Adirondacks and other regions and may mark the beginning of such a segregation.

It is not easily explained by fractional crystallization aided by convection currents as proposed by Becker ${ }^{2}$ and later modified by Pirsson, ${ }^{3}$ although the probable sill-like form and basic character of the Preston gabbro would seem to favor the same method of differentiation as that which Pirsson has shown to have taken place in the shonkinite laccoliths of the Highwood Mountains of Montana. In the latter instance the cooling of the magma caused augite to crystallize first, and this mineral was segregated by convection currents along the floor, sides, and even the roof of the laccolith. The result was an outer accumulation of basic rock, shonkinite (montanose), in which augite was the first silicate to crystallize, with an inner core of syenitic rock (borolanose) which contained hornblende instead of augite. Water vapor, etc., was concentrated along the inner walls of the shonkinite crust, and developed a pegmatitic mantle around the syenitic core. No special mention is made of the 6 per cent of metallic minerals, but to judge from an illustration of a similar shonkinite ${ }^{4}$ it was partly older than and partly synchronous with the augite.

The Preston gabbro is quite different; first, because it consists of a small upper and a large lower portion instead of a small central core completely surrounded by a larger mass; and second, because its feldspar is distinctly the oldest mineral throughout the whole mass, whereas in the border facies the augite and any original hornblende is largely older than the metallic minerals and quartz. The latter minerals, which with apatite are segregated toward the upper border, were the last minerals to crystallize. The feldspar, first to crystallize, is not segregated, though it is less basic in the quartzose facies. Again, though the feldspar in the quartzose facies is distinctly the oldest mineral, its micropegmatitic relations both with quartz and with ilmenite show that the interval between their crystallizations was too short to permit complete separation. The same relation of pyroxene (and hornblende) to the quartz and magnetite further emphasizes this fact. The differentiation therefore must have taken place before any crystallization save perhaps that of the apatite.

Whatever the cause of this differentiation, the process seems to have been a tendency to simplify the main portion into a simple rock consisting only of essential minerals-pyroxene, perhaps olivine,

1 Leith, C. K., Econ. Geology, vol. 3, No. 4,1908, pp. 277-280.

2 Becker, G. F., Fractional crystallization of rocks: Am. Jour. Sci., 4th ser., vol. 4, 1897, p. 257.

3 Pirsson, L. V., Petrography and geology of the Highwood Mountains, Montana: Bull. U. S. Geol. Survey No. 237, 1905 , p. 187.

I Idem, Pl. VII. 
and labradorite. The few segregations in the eastern or lower portion of the mass, where olivine and bytownite are the essential minerals, may mark the limit to which this simplification had progressed before consolidation, or may possibly be complementary to the upper quartzose facies. Here the orthosilicates of-magnesia and lime, and to a less extent of iron, are the most abundant molecules. Failure to account for the high $\mathrm{Na}_{2} \mathrm{O}$ in analysis No. 1 bars it from the present discussion.

The materials eliminated from the main portion were $\mathrm{SiO}_{2}, \mathrm{Fe}_{2} \mathrm{O}_{3}$, $\mathrm{FeO}, \mathrm{K}_{2} \mathrm{O}, \mathrm{P}_{2} \mathrm{O}_{5}, \mathrm{H}_{2} \mathrm{O}$; a little $\mathrm{F}$, and perhaps $\mathrm{Cl}$. The water and any other gaseous material were presumably sufficient to give this minor fraction of the magma a lower specific gravity and greater mobility than the main portion, and the former worked gradually upward. This hypothesis confronts the objection of the extremely slow diffusion in rock magmas, ${ }^{1}$ but in this case the amount diffused is very small, and the presence of ilmenite and basic pegmatite in the porphyritic gabbro show that it was by no means complete.

If the magma had remained fluid long enough, this minor portion might have succeeded in segregating into a quartz-ilmenite-apatite mass along the upper contact, forming a deposit of the pegmatitic type (p. 117); or it might have split into two parts, one of quartzfeldspar, the other of apatitic iron ore; but as the cooling was too rapid for this complete segregation, the three minerals named became entrapped in the upper portion of the gabbro, and served only to give the distinctive accessory minerals to the quartz-hornblende variety.

The $\mathrm{K}_{2} \mathrm{O}$ aided by $\mathrm{H}_{2} \mathrm{O}$ and by any $\mathrm{F}$ present went to form biotite. It is very possible, owing to the presence of $\mathrm{H}_{2} \mathrm{O}$ and $\mathrm{F}$, that primary hornblende was formed; but, owing to the presence of primary augite and undoubted secondary hornblende, this point remains in doubt.

The apophyses and local segregations of oligoclase granite are clearly minor differentiations from the quartz-hornblende gabbro, and evidently resulted from a concentration of $\mathrm{SiO}_{2}, \mathrm{Al}_{2} \mathrm{O}_{3}, \mathrm{Na}_{2} \mathrm{O}$, $\mathrm{K}_{2} \mathrm{O}$, and $\mathrm{H}_{2} \mathrm{O}$. At the contacts this more highly fluid portion was able to penetrate the schists for some distance and produce the thin sheets and even stringers of fairly medium-grained texture. As there appears to be at the contact a gradation in composition toward this acidic extreme (see p. 111) it would seem that the differentiation was in progress before crystallization took place. The local segregations and intrusions of this acidic phase in the quartz-hornblende gabbro represent similar occluded concentrations. They, too, are best explained by supposing that differentiation took place before crystallization. If we regard it as a residual concentration, similar to pegmatite, we should expect it to consist chiefly of the last minerals of the magma to crystallize; but magnetite is inconspicuous. The

1 Becker, G. F., Some queries on rock differentiation: Am. Jour. Sci., 4th ser., vol. 3, 1897, p. 21. 
facts are better explained if we regard this acidic portion as having segregated as an immiscible fluid before crystallizing. As quartz, with ilmenite, was the last mineral to crystallize in the whole magma, the high percentage of quartz in the oligoclase granite would cause that rock to remain fluid somewhat longer than the surrounding rock; consequently, any rupturing that took place as the latter became solidified would allow the still fluid oligoclase granite to form local intrusions. The prominence of apatite in the granite would favor this view rather than the other.

In comparing the gradational character at the contact with the sharply separated segregations and intrusions just discussed, the former appears to be the result of incomplete differentiation on a large scale, the latter the completed product of differentiation on a small scale. The more rapid cooling at the contact may further account for the incompleteness of the process there.

As the oligoclase granite marks a separation of the acidic fraction of the magma, it would be natural to expect a complementary ultrabasic separation of $\mathrm{Fe}$ oxides, $\mathrm{MgO}, \mathrm{CaO}, \mathrm{TiO}_{2}$, and $\mathrm{P}_{2} \mathrm{O}_{5}$-a titanic iron ore with a gangue of olivine or pyroxene and apatite. Though none was found, small amounts of such material may well be hidden by glacial drift. The necessary mineral composition of such a basic complementary would be strikingly like that of the cumberlandite (rhodose) in northern Rhode Island. It is interesting to note that this cumberlandite bears an intrusive relation to a larger mass of associated gabbro, ${ }^{1}$ but in this case no complementary acidic rock has yet been identified.

To summarize the above discussion, the writer suggests that the different members of the Preston gabbro are the results of an incomplete differentiation. The ultimate products would have been a principal magnesia-lime portion, consisting of pyroxene and (or) olivine and basic plagioclase, and two minor portions complementary to each other-one a silica-alkali with $\mathrm{Na}_{2} \mathrm{O}$ greatly in excess of $\mathrm{K}_{2} \mathrm{O}$, the other a titanic iron-ore phase. The process had so far progressed that the constituents of these minor phases had collected in the upper portion, and were beginning to segregate into distinct bodies when consolidation took place. The result of this arrested differentiation was the quartz-hornblende gabbro.

\section{STERLING GRANITE GNEISS.}

TYPES.

The Sterling granite gneiss includes three prominent varietieseven-grained or normal biotite granite, porphyritic granite, and alaskite. Alaskite is the most abundant of the three within the area,

1 Johnson, B. L., and Warren, C. H., Contributions to the geology of Rhode Island: Am. Jour. Sci., 4th ser., vol. 25,1908, p. 12. 
and porphyritic granite the next. The normal granite occurs. within the southeastern limits, but lies mostly south of the area. The alaskite cuts the other two varieties, but all gradations in composition and texture among the three varieties occur. In addition to these principal varieties, a local hornblendic phase occurs in the southwest portion of the area. Minor intrusive sheets corresponding to all four varieties are found in the neighboring schists. Dikes and sheets of pegmatite and aplite are common, the latter agreeing in mineral composition with the alaskite. All the Sterling granite gneiss within the area possesses marked gneissic structure, but this character becomes very obscure as the normal variety is followed southward beyond the boundary. For convenience, the normal rock will be considered after the porphyritic and alaskite varieties.

\section{PORPHYRITIC GRANITE (LASSENOSE-TOSCANOSE).}

MEGASCOPIC CHARACTERS.

The color is gray to pink. The texture is coarse grained, porphyritic, gneissoid, and fits well the term "augen gneiss." Slickensides are common on joint and minor fracture surfaces. The pink, lensshaped feldspar phenocrysts vary in length from less than $\frac{1}{2}$ inch to

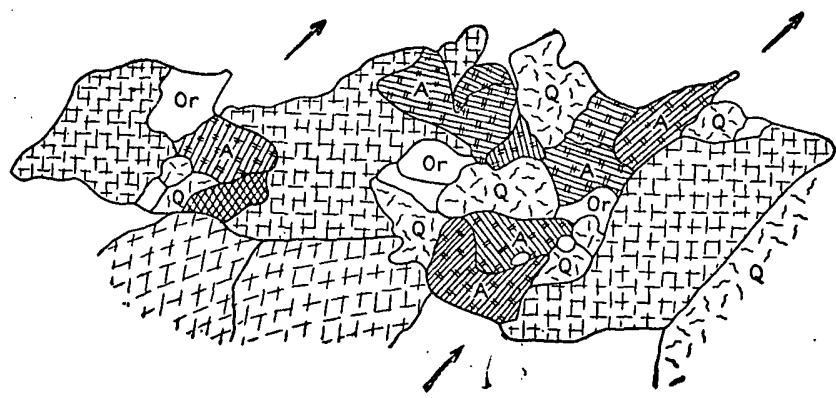

FIGURE 16.-Sliced microcline in alaskite. A, Albite; Or, orthoclase; Q, quartz.

more than 2 inches, and some reach even 4 inches. The smaller ones are rather well granulated, but the larger have suffered marked granulation only at the ends. The groundmass is gray, finely granular, and is made up principally of feldspar, quartz, and biotite. Biotite forms small flakes, mostly 1 to 2 millimeters long, uniformly oriented and rather uniformly distributed. Small grains of magnetite and, less commonly, of pyrite can be seen with the unaided eye, and minute yellowish titanite crystals can be detected with the aid of a lens.

\section{MICROSCOPIC CHARACTERS.}

The microscopic texture is gneissic, characterized by granulation and flaser structure in quartz and feldspar and by the shredded character of biotite. The primary minerals are microcline and orthoclase (mostly phenocrysts) (45 per cent), oligoclase (24 per cent), 
quartz (25 per cent), biotite ( 4 per cent); magnetite ( 1 per cent), titanite (1 per cent), and scattered grains of apatite and zircon; the secondary minerals are muscovite, chlorite, and ferruginous kaolin in varying but small amount.

The microcline phenocrysts are more granulated than is apparent in the specimen. Their component grains mostly show the characteristic microcline twinning, but a few of the larger ones are orthoclase. The latter are mostly adjacent to, or clearly pass into, microcline, proving the latter to be a secondary development. The laick of any definite orientation to the microcline grains shows well how they were rotated during metamorphism. Here and there two or more fragments uniformly oriented are separated by small narrow bands of very small, irregular grains of feldspar and quartz, as though forming the remnants of a sliced feldspar. ${ }^{1}$ Figure 16 illustrates a less extreme case of slicing. The rather high birefringence compared to that of the quartz suggests the presence of considerable $\mathrm{Na}_{2} \mathrm{O}$, as does the high extinction angle (over $9^{\circ}$ ) on sections cut near the plane of 010 . The occasional detection of microperthite and the high $\mathrm{N}_{2} \mathrm{O}$ in the chemical analysis given below confirm this evidence. Micropegmatite is a common occurrence.

Oligoclase occurs in small irregular grains averaging 1 to 2 millimeters in diameter. Their small size prevents them from showing any striking evidence of strain or fracturing. The very low extinction angles $\left(0^{\circ}-3^{\circ}\right)$ on the albite lamellæ ${ }^{2}$ determine the composition as $\mathrm{Ab}_{4} \mathrm{An}_{1}$.

The feldspars as a whole are but little altered. Minute specks of muscovite may be detected with high power, lying in the general direction of foliation. Scattered scales up to 1 millimeter in length occur in or directly associated with feldspar. Kaolin is developed along the cleavage and twinning planes and has badly clouded a few grains. It has a yellowish-brown tinge which points to the presence of associated ferric oxide. The pink to red color of the microcline in specimens varies directly with the amount of clouding in thin section, and is evidently due to this ferric oxide. In the freshest specimens the mineral is gray; in the most kaolinized it is red; in intermediate stages it is pink. Plagioclase in all these stages remains grayish to yellowish white. The occurrence together of reddish potash feldspar and whitish plagioclase is common in granites and is apparently due to the oxidation of some iron compound in the potash feldspar, though the exact relation of the iron compound to the feldspar has not yet been satisfactorily determined.

Quartz in general is highly granulated, though some elongate areas of coarse grains with diagonal fractures and some lines of the charac-

1 Term proposed by C. K. Leith, Bull. U. S. Geol. Survey No. 239, 1905, p. 38.

3 M. Levy's statistical method. 
teristic bubble inclusions are preserved. These grains are in many cases so strained that extinction takes place in alternate bands of light and shadow sweeping diagonally across single grains. This alternation is so strongly developed in some grains as to resemble rudely a broad lamellar twinning (fig. 17). The elongate quartz areas trail out into streaks of small elongate granules, which also possess undulatory extinction.

Biotite is uniformly oriented parallel to the foliation. It is partly shredded into long, veinlike forms undulating among quartz and feldspar grains, and is partly recrystallized into rows of short, unbent flakes. The edges and ends of the unbent flakes, especially the larger, are irregular and curve around the adjacent grains, suggesting a tendency to poikilitic development. Alteration has in many cases developed lenses of chlorite and flakes of muscovite parallel to the cleavage. Bleaching of the edges of the biotite

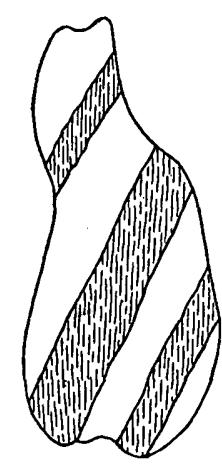

Figure 17.-Undulatory extinction in quartz resembling albite twinning. flakes is also rather common.

The magnetite, identified by its black metallic reflection and octahedral form, is thinly disseminated in comparatively large grains up to 1 millimetèr and more in diameter. Titanite forms rudely wedge-shaped grains, mostly less than 1 millimeter long, irregularly fractured, and having their long axes parallel to the foliation. It is uniformly distributed and is usually closely associated with magnetite or biotite. Its automorphic form and associations suggest a secondary origin. Apatite is thinly distributed, but in crystals relatively large ( 0.5 millimeter in diameter) and stout for a granite. Zircon is for the most part irregularly scattered in clusters. The clusters are made up of rounded or irregular grains, but minute isolated individuals are perfect doublyterminated crystals.

\section{CHEMICAL COMPOSITION.}

The chemical analysis and molecular ratios of the porphyritic variety are given in column 1 of the following table; that of a similar granite from Conanicut Island, R. I., in column 2. The analysis is that of a typical granite. The $\mathrm{CaO}$ appears somewhat high, and may be due in part to particles of epidote, which were noted in the field but not in thin section of the material analyzed. The prominence of the $\mathrm{Na}_{2} \mathrm{O}$, somewhat in excess of $\mathrm{K}_{2} \mathrm{O}$, is noteworthy.

\section{QUANTITATIVE CLASSIFICATION.}

In the quantitative system of classification the rock falls in Class I, order 4 , rang 2 , subrang 3 , close to 4 -that is, lassenose-toscanose. 
Analyses of Sterling granite gneiss and similar rocks.

\begin{tabular}{|c|c|c|c|c|c|c|c|}
\hline & 1. & 2. & 3. & 4. & 5. & 6. & 7. \\
\hline $\mathrm{SiO}_{2} \ldots$ & $\begin{array}{l}71.24 \\
1.187\end{array}$ & 71.23 & $\begin{array}{c}76.94 \\
1.282\end{array}$ & 77.33 & 70.87 & 76.73 & 76.44 \\
\hline $\mathrm{Al}_{2} \mathrm{O}^{3}$. & $\begin{array}{l}14.34 \\
.140\end{array}$ & 13.64 & $\begin{array}{c}12.59 \\
.123\end{array}$ & 12.55 & 12.52 & 12.70 & 120.95 \\
\hline $\mathrm{Fe}_{2} \mathrm{O}_{3}$ & $\begin{array}{l}.80 \\
.005\end{array}$ & 1.70 & $\begin{array}{l}.120 \\
.009\end{array}$ & .91 & .67 & 1.38 & $\because 19$ \\
\hline $\mathrm{FeO}$. & $\begin{array}{l}1.80 \\
.025\end{array}$ & 1.00 & $\begin{array}{l}.14 \\
.002\end{array}$ & & None. & Undet. & .89 \\
\hline $\mathrm{MgO}$. & $\begin{array}{l}.06 \\
.017\end{array}$ & .75 & $\begin{array}{l}.25 \\
.006\end{array}$ & .10 & .09 & $\because 12$ & Trace. \\
\hline $\mathrm{CaO}$ & 2.17 & $2.3 i$ & Trace. & .17 & .49 & .50 & .15 \\
\hline $\mathrm{Na}_{2} \mathrm{O}$ & $\begin{array}{l}.025 \\
4.25\end{array}$ & 3.55 & $\begin{array}{l}3.56 \\
.057\end{array}$ & 3.19 & 2.47 & 3.17 & 4.76 \\
\hline $\mathrm{K}_{3} \mathrm{O}$ & $\begin{array}{l}4.14 \\
.044\end{array}$ & 3.79 & $\begin{array}{l}5.33 \\
.056\end{array}$ & 4.80 & 5.78 & 4.55 & 4.95 \\
\hline 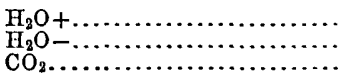 & $\begin{array}{c}.03 \\
.05 \\
\text { None. }\end{array}$ & 1.72 & $\begin{array}{l}.22 \\
\text { None. } \\
\text { None. }\end{array}$ & $\begin{array}{r}.53 \\
.15 \\
\text { None. }\end{array}$ &. .52 & .57 & .09 \\
\hline $\mathrm{TiO}_{2} \ldots \ldots \ldots \ldots \ldots$ & $\begin{array}{l}.40 \\
.005\end{array}$ & .21 & $\begin{array}{l}.08 \\
.001\end{array}$ & .09 & .11 & .24 & .37 \\
\hline $\begin{array}{l}\mathrm{P}_{2} \mathrm{O}_{5} \ldots \ldots \ldots \ldots \ldots \ldots \ldots \ldots \ldots \ldots \ldots \ldots \ldots \ldots \\
\mathrm{ZrO}_{2} \ldots \ldots \ldots \ldots \ldots \ldots \ldots\end{array}$ & $\begin{array}{l}\text { Undet. } \\
\text { Trace. }\end{array}$ & $\begin{array}{l}\text { Undet. } \\
\text { Undet. }\end{array}$ & $\begin{array}{l}\text { None. } \\
\text { Undet. }\end{array}$ & Trace. & .05 & & \\
\hline $\mathrm{MnO}_{3}$. & $\begin{array}{l}.02 \\
.000\end{array}$ & .05 & Trace. & Trace. & & ... & Trace. \\
\hline \multirow[t]{2}{*}{ 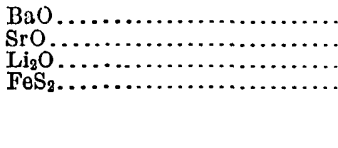 } & $\begin{array}{c}\text { None. } \\
\text { Undet. } \\
\text { None. } \\
.18 \\
\end{array}$ & $\begin{array}{l}\text { Undet. } \\
\text { Undet. } \\
\text { Undet. } \\
\text { Undet. }\end{array}$ & $\begin{array}{l}\text { Undet. } \\
\text { Undet. } \\
\text { Undet. } \\
\text { Undet. }\end{array}$ & $\begin{array}{l}\text { Trace. } \\
\text { Trace. } \\
\text { Trace. } \\
\text { Undet. }\end{array}$ & & & n..... \\
\hline & 100.08 & 99.95 & 100.40 & 99.82 & 99.82 & 99.06 & 100.79 \\
\hline
\end{tabular}

1. Gneissoid porphyritic granite (Sterling granite gneiss), Griswold, Conn.; W. A. Drushel, analyst.

2. Porphyritic granite, Conanicut Island, R. I.; L. V. Pirsson, analyst.

3. Gneissoid alaskite (Sterling granite gneiss), Led yard, Conn.; G. F. Loughlin, analyst.

4. Typical alaskite, Terra Cotta Range, Alaska; H. N. Stokes, analyst.

5. $\Lambda$ plite, Nettie mine, Mont.; H. N. Stokes, analyst.

6. A plite granophyre, Mennum, Norway; R. Manzelius, analyst.

7. Aplite, Bass Rocks, Cape Ann, Mass.; H. S. Washington, analyst.

\section{ALASKITE (ALASKOSE-LIPAROSE).}

The name "alaskite" was first used by Spurr" as a group name for rocks "consisting essentially of alkali feldspar and quartz without other essential minerals" and corresponding to the alkaline granite of the German classifications. To the three subdivisions of alaskite given by Spurr, "granular, panidiomorphic, and porphyritic," a fourth, "gneissoid," may be added to include the rock herein described.

\section{MEGASCOPIC CHARACTERS.}

The prevailing color is pink. The texture is gneissic and medium to coarse grained. The surfaces normal to the foliation consist of short bands or lenses of pink and white feldspars separated by shorter and narrower lenses of smoky quartz. The moderately granular character of the feldspar is distinct, owing to the lack of continuous cleavage surfaces. The minerals visible are pink potash feldspar, white plagioclase with distinct albite twinning in some cases, smoky quartz, biotite, in some sections muscovite, and magnetite in small but distinct octahedra. The magnetite and mica are very thinly scat- 
tered. The biotite is practically invisible on surfaces normal to the foliation, and magnetite there appears as the only black constituent. Increase of biotite in some specimens marks a gradation to normal granite (p. 126). Development of muscovite in places of pronounced shearing produced local variations of muscovite granite.

\section{MICROSCOPIC CHARACTERS.}

The microscopic texture approaches xenomorphic granular. The minerals detected are microcline (40 per cent), albite (20 per cent), quartz (40 per cent), with some biotite and muscovite (1 per cent), magnetite (less than 1 per cent), some grains of zircon and pyrite, and a faint sprinkling of ferruginous kaolin.

Microcline occurs in elongate, granular aggregates, showing incipient kaolinization along the twinning planes. Numerous round and irregular inclusions or micropegmatitic intergrowths

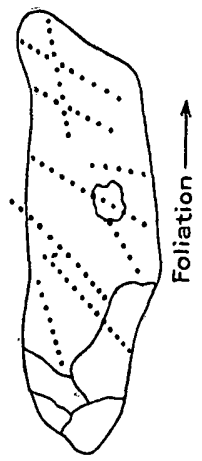

Figure 1.S.-Granu lation and weld fractures (?) of a quartz grain in alaskite. of quartz are inclosed. Small rounded microclines are also inclosed in quartz. Strain and mashing effects are evidenced by undulatory extinction, quite as prominent as in the quartz, and by the granulated character of the grains. Slightly curved lamellæ are occasionally seen. The sliced character (fig. 16, p. $120)$ is very well developed.

The secondary character of the microcline twinning structure is clearly shown by gradation into orthoclase. No good opportunity was offered for measuring the extinction angle on 010 sections, and its sodic character can only be inferred by the small amount of albite present in comparison to the $\mathrm{Na}_{2} \mathrm{O}$ in the chemical analysis (No. 3, p. 123).

The albite is closely associated with microcline, forming much smaller and less broken grains. It is readily identified by the extinction angles of albite lamellæ on opposite Carlsbad twins. It has, in some cases, crystallized prior to the microcline (or orthoclase), but the intimacy of both feldspars and of quartz indicates that their periods of crystallization greatly overlapped one another.

Quartz (fig. 18) occurs in elongate grains with undulatory extinction and with but a minor amount of granulation in comparison to the feldspar:- There is no evidence of the slicing so well developed in the microcline. Characteristic lines of bubble inclusions are fairly numerous. They cross the grains or granular aggregates at angles to the long edges, varying, but mostly between $60^{\circ}$ and $30^{\circ}$, as though they represented welded fractures produced by shearing in the direction of elongation. Some of these lines can be followed a very short distance into the adjacent feldspar. Occasionally large grains, free from undulatory extinction, appear to be secondary and 
to form small veinlets, but the general absence of alteration, other than the slight kaolinization mentioned, does not especially favor a secondary origin for them. They may equally well be attributed to small residual amounts of $\mathrm{SiO}_{2}$ which consolidated after the rock as a whole, too late to undergo compression and granulation. The significance of the comparative strain effects in the feldspar and quartz will be discussed (p. 127) after the descriptions of the remaining granite types.

Biotite, where present in any noteworthy amount, occurs in very small, thinly scattered flakes, mostly inclosed in quartz and feldspar. The smaller flakes have sharp edges and irregular but not resorbed terminations; the larger have both irregular edges and terminations. The irregularity of outline and, in addition, the lack of bending of the flakes are strong indications that they have completely recrystallized under pressure, and have tended to grow around the quartz and feldspar grains. Incipient alteration has produced a greenish color in plane polarized light, which in some specimens has given way to bleaching. A few uncommon flakes appear to have altered to muscovite, and one or two are fringed by fine, minutely granular rims, undetermined, but presumably consisting of some carbonate.

Muscovite as a rule is very rare, and is nearly all derived from feldspar. It generally occurs in thin, drawn-out flakes along the edges of and to some degree penetrating the mashed feldspar. Less commonly, poorly terminated muscovite flakes lie in the central parts of feldspar grains, in the general direction of foliation.

Magnetite occurs in sparsely scattered grains, many of which are distinctly mashed and have planes of parting developed, some normally and others obliquely to the direction of the elongation. But one grain of pyrite was noted. Zircon is scarce, commonly in minute, isolated crystals, and here and there in small clusters.

CHEMICAL COMPOSITION.

The chemical composition of the alaskite is given in analysis 3, page 123, together with analyses of similar rocks taken from Spurr's paper ${ }^{1}$ and from Washington's "Chemical analyses of igneous rocks." 2

Analyses 3 and 4, respectively, show the similarity of the Connecticut rock to typical alaskite. Analyses 5, 6, and 7, all of aplites, are selected from several similar ones tabulated in Washington's paper to show the uniform character in widely scattered occurrences. All are characterized by low iron oxides, very low $\mathrm{MgO}$ and $\mathrm{CaO}$, and rather high alkalies, with $\mathrm{K}_{2} \mathrm{O}$ as a rule predominating over $\mathrm{Na}_{2} \mathrm{O}$. They are residual portions of granite magmas and differ from pegmatite chiefly in coarseness of grain. The uniformity in composition of these residual portions from different granite magmas is certainly striking, and points to a definite product of differentia-

1 Op. cit., p. 231.

2 Prol. Paper U. S. Geol. Survey No. 14, 1903, pp. 126, 128, 144. 
tion in granite magmas. Comparison of 1 and 3 brings out the differences between the main or normal magma and its alaskite phase, the $\mathrm{SiO}_{2}$ and the alkalies being segregated in the alaskite.

The Connecticut occurrence is similar in general characters to typical alaskite. Both carry soda orthoclase and microcline, and both show transitions into typical biotite granite. ${ }^{1}$

\section{CLASSIFICATION.}

The names alaskite and binary granite in the more familiar classifications both fit the rock. According to the quantitative system, the rock falls into Class I, order 3, close to 2, rang 1, and subrang 3 -that is, alaskose-liparose.

\section{NORMAL OR EVEN-GRAINED GRANITE.}

The petrography of the normal or even-grained rock occurring chiefly south of the area needs no detailed consideration. Its most noteworthy character, other than its lack of distinct phenocrysts and normal biotite content, is its comparative lack of strain effect. Undulatory extinction, but little or no granulation or spreading out of biotite flakes, is evident. Orthoclase, as well as microcline, is relatively abundant. These characters are evidence that metamorphism diminished in amount to the southward. This rock at Westerly, R. I., 3 miles south of the area, is quarried under the name of Westerly red granite.

\section{HORNBLENDIC GRANITE.}

Only one outcrop of hornblendic granite was noted, about 2 miles north of the southwest corner of the area. It is gneissic, with the average percentage of dark minerals, but is finer grained than the normal biotite variety just described. Hornblende, in thin section, is found to predominate over biotite, and orthoclase over microcline. Quartz and feldspar show undulatory extinction but only slight granulation. Biotite and hornblende, however, present the irregular boundaries of recrystallized minerals as in the alaskite. These moderate strain effects confirm the evidence presented by the normal biotite variety; that is, that compression diminished southward. In many specimens magnetite is surrounded by rims of titanite, which in turn are surrounded by hornblende and biotite. It may be a question whether the titanite is a primary mineral or a secondary reaction rim deriving $\mathrm{TiO}_{2}$ chiefly from the magnetite and $\mathrm{CaO}$ and $\mathrm{SiO}_{2}$ from the hornblende; but its position favors the latter interpretation.

\section{MINOR INTRUSIVE SHEETS AND DIKES.}

The large areas of both porphyritic and alaskite varieties are thought to be enormous intrusive sheets. (See p. 35.) The following descriptions refer only, to the smaller sheets, 100 feet or less in thickness.

1 Spurr, J. E., A reconnaissance in southwestern Alaska in 1898: Twentieth Ann. Rept. U. S. Geol. Survey, pt. 7, 1900, p. 195. 
All four varieties of the granite above described are represented. Dikes are rare and are not separately considered.

\section{MEGASCOPIC CHARACTERS.}

The sheets, except for most of those composed of alaskite, differ from the main masses chiefly in presenting a more highly mashed and sheared character, due to their small size and their position in the highly metamorphosed sediments. Many have a decidedly dirty or dull appearance, due to the prominence of green secondary minerals.

\section{MICROSCOPIC CHARACTERS.}

Excessive shearing is the chief feature in thin section. The phenocrysts in the porphyritic sheets are almost obliterated, and are recognized only by the border of shredded or completely recrystallized biotite around their granulated remains. A most unexpected feature is the large amount of orthoclase in some of the most severely mashed occurrences. Muscovite, as would be expected, is abundant. Epidote and chlorite are associated with biotite and hornblende, and are abundant in every section containing these two minerals. Weathering is more pronounced than in the large masses.

\section{PEGMATITE.}

The pegmatite is very simple in mineral composition. Besides pink microcline, white albite, biotite, and a small amount of musco'vite, a few tourmalines were the only minerals noted. It should be said, however, that no special search was made for minerals characteristic of pegmatites, and that the rather weathered outcrops did not afford much opportunity. In the quarries at Westerly, R. I., and at South Lyme, Conn., where the pegmatite is well exposed, Kemp ${ }^{1}$ has noted rare occurrences of tourmaline, molybdenite, and monazite; but he also shows that the composition of the pegmatites is as a whole very simple. Small, finer-grained apophyses of pegmatite are indistinguishable from alaskite, which in turn grades into an aplite texture; but the presence of pegmatite sheets and dikes in the alaskite shows the former to be more than a textural variation of the latter, as the aplite seems to be.

\section{RELATION OF MICROSTRUCTURE OF THE STERLING GRANITE GNEISS TO REGIONAL METAMORPHISM.}

\section{RELATION OF INTRUSION AND DEFORMATION.}

Though it may hardly be wise to make a positive statement regarding the relation of the Sterling granite gneiss to regional metamorphism as revealed by the microscope, nevertheless a discussion of the possible relations leads to some interesting conclusions. It was shown in the petrographic description of the alaskite that the feldspar 
showed the effects of pressure and regional movement more strongly than did the quartz; and it is evident that these two minerals are the only ones in the rock sufficiently abundant to show the character and degree of deformation.

Intrusion may have taken place under three possible conditions in relation to regional movement: (1) The magma may have come to rest, crystallized, and cooled before any movement of deformation took place; (2) it may have been intruded during or after deformation and not have crystallized until after the movements had ceased; or (3) it may have been intruded while the movements were in progress and have become completely crystallized before they had entirely ceased. In this last case any deformation would take place while the temperature of the rock was close to its melting point.

1. If the magma had crystallized and cooled before deformation took place the original rock would have been a normal granitic rock, with hypautomorphic texture. When the deforming stresses were applied, the minerals would have suffered mashing, alteration, and recrystallization in the presence of a sufficient amount of solvents, the amount of change depending upon the magnitude and duration of the stresses. There would have resulted a development of gneissic structure accompanied by granulation of the quartz and feldspar. The feldspar and quartz grains would have been mashed and drawn out, and each would appear under the microscope as a more or less distinct central core surrounded by a thick cluster of granules, most abundant at the ends of the core which lay in the foliation planes. There would be no definite crystallographic orientation, and all the particles, regardless of size, would show undulatory extinction. These characters would be more strongly developed in the quartz than in the feldspar, as the former has been shown by Leith ${ }^{1}$ to be decidedly the more subject to granulation. The feldspar, in the presence of a scanty amount of mineralizers, would have tended to develop secondary muscovite parallel to the foliation, and the rock would have approached a muscovitic schist in character, according to the amount of feldspar alteration and the degree of mashing. It seems probable that this type of alteration would have taken place chiefly along certain zones of shearing, the shear zones forming a network among masses that suffered only a slight degree of mashing. Such was evidently the case in the Preston gabbro (p. 39).

2. If the intrusion took place during or after deformation and was not crystallized until after movement had ceased, crystallization would have been begun under uniform pressure, with no shearing movement, and the minerals would have been free to develop in any direction. Normal granitoid texture would have resulted, and no secondary muscovite would have been derived from the feldspar. Only a

1 Leith, C. K., Rock cleavage: Bull. U. S. Geol. Survey No. 239, 1905, p. 64. 
renewal of movement could have produced any deformation in the rock, and the conditions would then have been the same as in the first case.

3. If intrusion began during deformation and crystallization was well advanced before compression ceased, the feldspars would have crystallized either with no definite orientation or, more likely, with their longest dimensions in the direction of flowage. After crystallization had become so far advanced that the rock became a mass of feldspar crystals (plus a small amount of quartz) with interstices filled with still fluid quartz, the feldspars would suffer strain, rotation, and slicing, and become a more or less granular lens-shaped aggregate, elongated in the direction of least pressure. As the temperature would still be close to that of the crystallization, or melting point, of the - feldspar, the development of secondary muscovite would be unlikely. As the interstitial quartz began to crystallize, it would be obliged to take on the form of the elongated or flattened interstices. If movement were to cease at this $\operatorname{tim} \theta$, the elongate quartz grains would show little or no undulatory extinction; but if it were to continue longer, the quartz, like the feldspar, would in turn begin to suffer strain and granulation. With continued or renewed movement, after the rock had become well consolidated, these conditions would gradually pass into those of the first case.

An occurrence analogous to the last named is described by Adams. ${ }^{1}$ The rock in this instance is anorthosite. It has suffered granulation, but shows none of the secondary hornblende and saussurite which are typical of metamorphosed gabbros. He concludes that, as the rock was still deeply buried and at a very high temperature, perhaps close to the melting point, the minerals were obliged to retain their original identity and could not form the secondary hydrous minerals which are developed in rocks that have cooled prior to metamorphism.

\section{EVIDENCE IN ALASKITE.}

The alaskite variety of the Sterling granite gneiss, judging from its microscopic characters, crystallized under conditions analogous to case 3 (above). The feldspars, so far as the original crystals can be made out, had no definite orientation. Twinning strix lie in numerous directions, with but very few approaching to parallelism with the foliation. It is very possible that the crystals originally were oriented with their diagonals (longest dimensions) in the direction of flowage, but the field of the microscope was too small to prove such a position. Rotation, furthermore, during granulation, may have destroyed such an orientation. Granulation, though always present, is not as a rule very far advanced, and a good idea of its amount may be obtained from the sketch of a sliced microcline (fig 16,

1 Adams, F. D., Das Norian oder Ober-Laurentian von Canada: Neues Jahrb., Beil. Bd. 8, 1893, p. 462. 13338 - Bull. $492-12-9$ 
p. 120). The development of microcline twinning and its undulatory extinction add to the evidence that the feldspar had crystallized before being subjected to strain.

The quartz, although much more subject than feldspar to deformation under pressure, shows a less amount in the alaskite. Its elongated areas in general show but the beginning of granulation, and appear as if fractured near their ends by compression in the direction of their least dimensions (fig. 18, p. 124). The rows of bubble inclusions may mark welded fractures, but they are not indicative of marked granulation; and these possible welded fractures appear to have postdated the development of granulation, as they continue uninterrupted from one granule into another. This small degree of granulation, supplemented by undulatory extinction, proves that the original quartz grains must have been elongate and that they had crystallized before movement had entirely ceased. The microscopic veinlets of clear, unstrained quartz indicate that movement had entirely ceased before the very last portion of quartz crystallized. The unmashed character of narrow dikes and sheets of pegmatite associated with the alaskite points to the same conclusion.

The continuing of pressure for a short time after the rock as a whole had consolidated, could account for the incipient development of muscovite from the feldspar. In exceptional cases, where movements were concentrated along shear planes, more extensive development of muscovite was possible; and it is in accordance with this idea that the scattered outcrops of muscovitic rock show a more highly foliated and friable character than do the exposures of the typical mica-free rock.

\section{EVIDENCE IN PORPEYRITIC GRANITE.}

Evidence in thin sections of the porphyritic variety of the Sterling granite gneiss is not so clear, as these represent an area (east of the gabbro mass) where metamorphism was more severe. Quartz, which in these sections is as highly granulated as the feldspar or slightly more so, shows that the rock was subjected to a greater amount of movement after consolidation. This indication agrees with the fact that the porphyritic granite was intruded before the alaskite. The absence of muscovite in large amount indicates that the rock still had a temperature near its melting point when subjected to granulation.

Along the foliation of the porphyritic granite the minor contortions, similar to those developed in the less massive sedimentaries, indicate that the granite must have been in a relatively plastic state at the time of folding. The gabbro mass, in contrast, is not, as a whole, gneissic. It yielded to pressure, as mentioned above, along certain shear zones, in which the rock became drawn out into more or less 
schistose hornblendic rock. The greater portion did not suffer complete recrystallization and shows little or no gneissic structure. If the porphyritic granite had become completely solidified and considerably cooled before the period of compression, it should have resisted schistose development as well as the gabbro, since its chief minerals, feldspar and quartz, are less liable to recrystallization than the pyroxene (and possible primary hornblende) in the gabbro. If thoroughly consolidated it should have suffered in the same way as the gabbro, by the development of schistose zones among masses of undeformed rock. If fluid or not completely consolidated, schistose or flow structure and minor contortions would readily be developed; and the minerals, on crystallizing, would become granulated and drawn out along the planes of schistosity. The continuing of severe compression until after the quartz had solidified would cause the degree of granulation seen in the thin sections. Thus the total evidence indicates that the porphyritic granite was intruded and became completely crystallized during the period of compression and folding.

EVIDENCE IN NORMAL STERIING GRANITE GNEISS.

The relatively slight pressure effects in the normal granite give it no important place in the present discussion. The fact, however, that the quartz is distinctly strained, though the potash feldspar has only partly developed microcline twinning, and the presence of slight schistose development without granulation, indicate that the rock flowed and completely solidified during a period of slight compression. This evidence, though not very convincing on account of the slightness of compression, classes the rock as essentially contemporaneous with the porphyritic granite.

SUMMARY.

To sum up these conclusions, microscopic evidence and comparison with the gabbro show that the porphyritic and normal varieties of the Sterling granite gneiss were intruded during the period of compression and were consolidated while compression was still at its height; that the alaskite was intruded during the later stages and became consolidated as the compressive strain died out; that the pegmatite associated with the alaskite was intruded and consolidated after compression had practically ceased.

\section{AGE AND CONDITIONS OF THE GRANITE GNEISS INTRUSION.}

If the above conclusions are correct, and it is true that the metamorphosed sedimentaries of the area are of Carboniferous age (p. 16), the intrusion of the Sterling granite gneiss must have accompanied the great orogenic movement which folded the Carboniferous strata; 
that is, the Appalachian revolution. The recrystallization of the sedimentaries must have begun previous to the intrusion of the granite, as inclusions of schist are found in the granite and as, with the exception of a few stringers of aplite, no intrusions were found cutting across the foliation; but the granite suffered all the minor contortions found in the schist, and, as shown above, was intruded during the period of metamorphism.

With these facts as data, the following hypothesis may help toward an explanation of the metamorphism and structure of the region. The local sedimentaries were among the earliest Carboniferous strata deposited, and owing to continued depression of the region, became buried to a considerable depth, but probably not to the depth (generally considered from 5 to 7 miles) at which recrystallization and closing up of pore space would, theoretically, result from superincumbent pressure.

In the meantime the Sterling granite gneiss batholith had been slowly working upward, undermining an extensive area, and slowly raising the temperature of the overlying strata. As undermining and surface erosion progressed simultaneously, the thinned sedimentary cover gradually began to yield to the prevailing lateral pressure and became completely folded, probably into mountain ranges. The heat and pressure acting on the lowest beds, aided by emanations uprising from the granite magma, caused them to recrystallize and assume their schistose structure during folding. The granite, continuing to work upward, now found easiest access along the foliation of the schist, and formed intrusive sheets, which (p. 36) were gradually followed by the batholith proper.

The bands of schist to-day exposed at the surface are but the uneroded remnants, or "roots," of a considerable, but indefinite, thickness of sediments. No reliable means exists for estimating this thickness. Woodworth estimated the thickness of the Carboniferous of the Narragansett Basin, R. I., about 15 miles east of this area, to be between 12,100 and 12,600 feet, ${ }^{1}$ or somewhat over 2 miles. It is possible that the schists of the region under discussion are a continuation of the Narragansett Basin strata and have an equal, or even greater, thickness. This possibility implies that the zone of flowage, resulting from a combination of heat and any mineralizing emanations from the granite and of the regional compression, reached within 3 or even within 2 miles of the surface.

Joseph Barrell, ${ }^{2}$ by calculating the thickness of the eroded roof, has shown that the batholith at Marysville, Mont., reached within a mile of the surface. In that locality, however, regional compression

\footnotetext{
1 Woodworth, J. B., Mon. U. S. Geol. Survey, vol. 33, 1899, p. 134.

2 Geology of the Marysville mining district, Montana: Prof. Paper U. S. Geol. Survey No. 57, 1907, p.166. The author also cites other instances where batholiths have reached within a mile of the surface.
} 
was not sufficient to produce rock flowage and schistose structure, though heat and mineralizers from the magma were sufficient to produce contact metamorphism. The fact, however, that granite batholiths can reach so near to the surface shows that it is not wholly unwarranted to estimate that the granite batholith and the accompanying zone of flowage, where regional compression was great, may have reached within 3 or even 2 miles of the surface. Further discussion is not attempted here, as the required data are lacking, but the above is thought worth while as a suggestion to be considered in future work.

\section{PROBABLE EXTENT OF THE GRANITE GNEISS BATHOLITH.}

The above statements regarding the relation of the Sterling granite gneiss to the period of metamorphism raises the question as to whether the granite areas throughout the whole crystalline region of the State can be similarly correlated. The writer can not answer this question for the whole region, but the following conditions indicate that the Sterling granite gneiss batholith continues well beyond the limits of the area under consideration:

A striking resemblance prevails among the granites along the shore of Long Island Sound from Lighthouse Point, New Haven, the western extremity of the eastern crystallines of Connecticut, to Conanicut Island, R. I., in Narragansett Bay. They are with few minor exceptions biotite granites, and contain red and white feldspar. The Connecticut and western Rhode Island occurrences all cut the same formation-a dark gray schist or gneiss. Thin sections from several localities, including Branford on the west and Conanicut Island on the east, present the same general characters, and point to chemical similarity, especially as regards the prominence of $\mathrm{Na}_{2} \mathrm{O}$. However, no systematic comparison has yet been made, and only the Sterling granite gneiss and that of Conanicut Island ${ }^{1}$ have been described in detail.

The granite of Conanicut Island bears the same description as the porphyritic variety of the Sterling granite gneiss, save that it has suffered more chemical alteration. Pirsson mentions no soda orthoclase, but its presence, to judge from the percentage of $\mathrm{Na}_{2} \mathrm{O}$ in the analysis (p. 123), seems very likely. The whole analysis agrees closely with that of the porphyritic variety of the Sterling granite gneiss. All the principal constituents save the alkalies are practically the same for both rocks. The deficiency of alkalies in the Conanicut Island rock is balanced by the higher percentage of water, and the difference therefore can be attributed to weathering.

The west shore of Narragansett Bay, just south of Narragansett Pier, is composed of intrusive granite which is identical in appearance 
with the normal Sterling granite gneiss and is cut by alaskite of the Sterling type.

The writer has seen specimens of porphyritic gneissoid granite from Lyme, Conn., just east of the Connecticut River, which he could not distinguish from the typical porphyritic variety of the Sterling granite gneiss within the area; and, as the surrounding rocks (gray schist and gneiss) are the same throughout the intervening area, it seems pertinent to extend the westward limit of the batholith at least as far as Connecticut River. Furthermore, the similarity of the coarse-grained granite quarried at Lyme station to that found at Stony Creek, in the town of Branford, Conn., suggests a still greater westward extent, limited only by the eastern boundary of the Triassic area.

This correlation recalls the fact that J.G. Percival ${ }^{1}$ in 1842 grouped all the granites from East Haven eastward into one formation. The granite, according to his description, "forms a very extended range. which may be traced along the coast from the lighthouse (East Haven) * * * into Rhode Island and thence northerly along the eastern border of the State, into Massachusetts. Throughout this extensive range there appears such a general uniformity of character in the rocks composing it as to entitle it to be considered a distinct and separate formation." J. F. Kemp ${ }^{2}$ has also recognized the predominance of biotite granite along the Atlantic seaboard.

Comparison between the Sterling granite gneiss and the neighboring granite areas in Canterbury, Franklin, and Bozrah ${ }^{3}$ does not bring out so close a similarity. These areas are of muscovitic granite, highly mashed and nearly white in color. Their difference from the Sterling granite gneiss may be due largely to dynamometamorphism, but they have yet to be thoroughly studied before they can be reasonably compared. It is noteworthy that these granite masses, like the Sterling, are intrusive into the surrounding formations.

The Maromas granite gneiss of Gregory, ${ }^{4}$ in Middletown and Portland, near and at the middle of the eastern Triassic border, generally lacks the pink color of the typical Sterling rock; but it closely resembles the latter in texture and mineral composition, and its porphyritic phase contains some pink phenocrysts. "There is evidence of a slight amount of crushing" but "it seems probable $* * *$ that the gneissoid structure was in part produced before the rock was completely solidified." These characters favor its correlation with the Sterling granite gneiss. It possesses other features-a granulitic

\footnotetext{
1 Report on the geology of Connecticut, 1842, p. 149.

2 Bull. Geol. Soc. America, vol. 10, 1899, pp. 361-382.

8 Towns northwest and west of the area described. For position and extent of formations, see Gregory, H. E., and Robinson, H. H., Preliminary geological map of Connecticut; Bull. Connecticut State Geol. and Nat. Hist. Survey No. 7, 1906.

- Rice, W. N., and Gregory, H. E., Bull. Connecticut Geol. and Nat. Hist. Survey No. 6, 1906, p. 144.
} 
contact zone, a basic phase, and a number of amphibolite intrusionsthat have not been observed in the Sterling granite gneiss within the area; but these, though they render the correlation uncertain, are not -sufficient to disprove it.

To sum up the evidence, it seems most probable that the Sterling granite gneiss batholith extends westward along the southern New England coast from Narragansett Bay to the Connecticut Triassic area, and northward along the Connecticut-Rhode Island boundary nearly to, if not beyond, the Massachusetts line. Its existence in east-central Connecticut is uncertain, though it may be represented there by the Maromas granite gneiss of Rice and Gregory.

\section{RELATION OF STERLING GRANITE GNEISS TO WESTERLY GRANITE.}

The Sterling granite gneiss at Westerly, R. I., and several other points to the east and west, is cut by small masses of a fine-grained, gray to pink biotite granite, known commercially as the Westerly granite. This fine-grained granite is similar mineralogically to the normal Sterling granite gneiss, though parts of it, at least, approach the character of granodiorite, and it may represent a later intrusion from the same magma. A study of the Westerly granite and of its relations to the Sterling granite gneiss would be an interesting sequel to the present work.

\section{GEOLOGY OF LANTERN HILL.}

Probably the most striking place in the area, if not in the whole of eastern Connecticut, both in its scenic features and geologic interest, is Lantern Hill, situated along the northern boundary of the area, between North Stonington and Ledyard. Lantern Hill is the highest point of a continuous ridge more than a mile long, which consists almost wholly of quartz. Its width at the base is more than 1,000 feet, but this includes a certain amount of talus. Its upper part, above the talus accumulations, is but a few hundred feet in width.

\section{IITERATURE.}

Published descriptions of this immense quartz mass have been made by three geologists within the last 70 years. The earliest account is that of W. M. Mather in $1834 .^{1}$ He seems to have confused Lantern Hill with the neighboring masses of gneissoid granite and gabbro ("sienite"); for he speaks of Lantern Hill as a "sienite" or "greenstone" mass.

The second account of Lantern Hill was by J. G. Percival ${ }^{2}$ in 1842. His description is very detailed and shows close observation. $\mathrm{He}$ noted the rock intermediate between the quartz mass and the neigh-

' Sketch of geology and mineralogy of New London and Windham counties in Connecticut, 1834, p. 24.

s Report on geology of Connecticut, 1842, p. 181. 
boring gneissoid granite, and drew the conclusion that "apparently the granite gneiss, as it approaches the central quartz vein, is converted into this peculiar talcose, that is, sericitic quartzy rock, in which there remains but a small proportion of feldspar." Although his was only a preliminary description and his work was too early to be aided by microscopic research, his conclusions, so far as they extend, accord with those of the present writer.

The third published account of Lantern Hill is an abstract of a paper by J. F. Kemp ${ }^{1}$ in 1896, who concentrated his attention on the quartz at the Silex mine, near the southern end of the ridge, and concluded that its pulverulent character was due to faulting or crushing movements; although, when on the spot, he had inferred the action of "some corroding alkaline solution, presumably magnesian." Kemp, ${ }^{2}$ three years later, in his paper on the granites of southern New England, mentions Lantern Hill as an extreme example of quartz of pegmatitic origin, but gives no description of the occurrence.

\section{GRISWOLD QUARTZ MASS.}

The fact that the whole Lantern Hill quartz ridge is separated from the nearest granite gneiss outcrops by large talus-filled ravines prevented safe conclusions regarding its origin until a small, similar deposit in Griswold, well exposed, had been studied. This latter was clearly a series of parallel veins, with intervening vertical sheets of replacement quartz after alaskite, and is attributed to pneumatolytic action.

The Griswold quartz mass is located about 1 mile north of Glasgo village, on the slope of a low hill which rises eastward from the main road. It occurs in fine-grained gneissoid alaskite which is cut by close, parallel joints. The joints are generally parallel to the foliation and are mostly filled with quartz, which forms a series of principal veins, from an inch or two to a foot or more in width, connected by a network of branches ramifying through the intervening wall rock in every direction and ranging down to microscopic dimensions. The veins possess comb structure, though not so markedly as do those at Lantern Hill. Their walls are generally not well defined, but are impregnated with quartz for short distances. This character is especially true of the smaller branching veinlets. Where these are sufficiently numerous, the impregnation has become a complete replacement, and the rock is a mass of finely granular quartz traversed by the more distinctly crystalline veinlets.

The quartz mass is largely covered by glacial till, and its length can be followed for only about 100 feet. Its width is not more than

\footnotetext{
1 The great quartz vein at Lantern Hill, Mystic, Conn., and its decomposition (abstract): Trans. New York Acad. Sci., vol. 15, 1896, p. 189.

${ }^{2}$ Kemp, J. F., Bull. Geol. Soc. America, vol. 10, 1899, p. 375.
} 
20 feet, but is sufficient to show the nature of its formation, all gradations between pure quartz and slightly altered alaskite being found. Where replacement is not complete, spots of light-brown kaolin mark the position of now decomposed but unreplaced feldspar; and, on weathered surfaces, removal of the kaolin has left irregular, but usually elongate, cavities, generally with small drusy quartz crystals projecting from their walls.

Besides quartz, a few minute cubes of pyrite are present, both in the veins and in the replaced rock. These also are weathered out on the surface, leaving rusty cavities which distinctly show the cubical outline of the pyrite and prove its secondary origin; for, if primary, its crystal outline, as was that of the magnetite in the alaskite, would have been largely destroyed by granulation.

A short distance south of the principal mass the alaskite is traversed by several prominent, though narrow, quartz veins, which mostly cut the rock at angles of $20^{\circ}$ to $30^{\circ} \mathrm{W}$. to the foliation. These veins form the acidic terminations of pegmatite veins. They also show the impregnating character along their walls.

Microscopic evidence, which is the same for all the quartz masses studied, will be postponed until after the description of the Lantern Hill quartz.

\section{LANTERN HILI QUARTZ MASS.}

\section{OCCURRENCE AND MACROSCOPIC CHARACTERS.}

The whole ridge, of which Lantern Hill is the highest member, lies very near the hidden contact of the alaskite variety of the Sterling granite gneiss with the metamorphic sedimentary rocks, or perhaps with the Preston gabbro (see Pl. II, in pocket) and is wholly within the limits of the alaskite. The two hills at the northern end of the ridge consist of broken ledges of quartz rock, all closely seamed, with the joints and minor fractures filled with quartz. The distinct veins here and throughout the ridge for the most part present a welldeveloped comb structure. Minor veinlets ramify through the rock in a well-defined network. The rock itself consists of porous, rusty, granular quartz, much of which has a marked pulverulent character, and is apparently held together by the network of veinlets. Many of the fragments can be split along foliation planes lined with films of pale-greenish sericite. At the north base of the eastern hill, on the road to Wintechog Hill, a vein 3 inches wide of massive quartz, with a few irregular crystals of pink feldspar, cuts an isolated outcrop of amphibolite.

Between these two hills and Lantern Hill proper a large, driftfilled gap and a very dense growth of brush hide all outcrops until near the summit. Between this and the summit there is another and smaller gap, bordered on each side by the quartz rock with a small 
included mass of quartz-biotite schist. The schist is highly contorted, badly rusted from oxidation of numerous secondary pyrite crystals, and traversed by several small veins with comb structure. This gap may be due to the erosion of a more extensive outcrop of schist, or perhaps of schist and alaskite, which had for some reason escaped replacement by quartz. Besides the weathering of pyrite, partial chloritization of the biotite is the only visible evidence of alteration in the schist. The comb structure of the veins is excellently developed at this point; vugs, or pockets, are rather common, and some of them are coated with thin incrustations of botryoidal turgite of more recent development than the quartz crystals.

The summit of the hill consists of many long, narrow roche moutonnée ledges of compact, milky quartz. Little or no comb structure is noticeable, and indications of parallel veining are decidedly obscure. Breaking of small fragments by frost action has completely destroyed the glaciated surface. The ridge at the summit is very narrow, and is bounded on both sides by vertical or slightly overhanging cliffs which extend downward at least 200 feet, where they become hidden by large talus accumulations. The cliffs on opposite sides are not more than 300 to 400 feet apart. The uniform character of the quartz and the isolation of the hill by the talus slopes conceal any clue to its origin.

On Long Hill, lying to the south, beyond another drift-filled gap, parallel veins again become very numerous and possess well-developed comb structure. The rock is in part compact milky quartz similar to that of Lantern Hill, but more commonly it is of the porous, rusted variety found on the two northernmost hills. In some places it has been broken away by frost action until the summit has become a narrow ridge only 10 to 20 feet wide. In most places where glaciated surfaces are exposed, the quartz is porous and possesses a distinct gneissic structure, which trends across the parallel veins in a direction varying from N. $56^{\circ} \mathrm{E}$. to N. $86^{\circ} \mathrm{W}$. These directions conform generally to the direction of the foliation in the alaskite to the east and west.

The gneissic structure is preserved by little ridges of quartz, which inclose elongate and generally rusty cavities. The ridges are commonly reenforced by veinlets parallel to their trend. Fresh fracture shows the rock to consist of the same porous, rusty, crumbly material that was found in the two northern hills. Many cavities have the cubical outline of pyrite, and others are irregular and elongate. Some of the latter are partly filled with ferruginous kaolin or with sericite, and-many show small quartz crystals growing from their walls. The ramifying network of veinlets traverses the rock in all directions.

Toward the southern end of Long Hill is a fourth sag, in which is located the Silex mine, a large open cut extending directly across 
the ridge. Parallel veins close together, few of them as much as a foot wide, are distinctly shown with their usual connecting branches in the vertical walls of the cut. The intervening rock as a whole is very free from iron stains, and is so crumbly that it can be mined without the aid of blasting. Small patches of white kaolin and palegreen sericite, mostly less than an inch in diameter, are scattered throughout the crumbly material. Analyses of this pulverulent quartz were said by J. F. Kemp ${ }^{1}$ to give from 98 to 99.4 per cent $\mathrm{SiO}_{2}$. This very high percentage is most likely due to the washing out of kaolin and sericite, either by natural or artificial means. The unwashed material gives a strong odor of kaolin and contains a distinct, though small, amount of sericite.

The remainder of the hill presents no additional characters. It slopes rather steeply to the south and finally passes beneath Long Pond. South of the ridge, outcrops of alaskite and normal granite and of some quartz-biotite schist are rich in highly quartzose pegmatite veins. Much of the quartz occurs in solid veinlike masses within the pegmatite, not of later formation, but clearly due to segregation of the last mineral in the pegmatite to crystallize.

Thus, both in structure and in its relations to the surrounding rock the Lantern Hill quartz ridge is similar to the small Griswold quartz mass; that is, it is an impregnation and replacement of the alaskite variety of the Sterling granite gneiss. This conclusion is verified by the microscopic characters.

\section{MICROSCOPIC CHARACTERS.}

In thin section the process of replacement can best be followed by beginning with the unaltered alaskite and passing through the intermediate stages to that of the compact milky quartz. The microscopic characters of the alaskite have already been given (p. 124), and it will suffice here merely to repeat that in thin section it consists almost wholly of elongate areas of alkali feldspars and quartz showing undulatory extinction, with scattered grains of magnetite, biotite, and muscovite. The feldspar may show some kaolinization and alteration to muscovite.

The intermediate rock, in which the gneissic structure is preserved, will be next described. In plane-polarized light without crossed nicols, the gneissic structure is distinctly shown by the difference in appearance between the elongate areas of clear granular quartz and intervening heavily clouded ones.

Between crossed nicols (Pl. XIV, $A$ ) the section appears much like that of a highly altered gneissoid granite. The long trailing areas of granular undulatory quartz lie adjacent to or surrounded by areas of sericite aggregates. The percentage of quartz is abnormally high. 
Quartz veinlets ramify through the section in numerous directions and form a considerable percentage of the total quartz. They are easily distinguished from original quartz both by their comb structure and by their lack of undulatory extinction. The edges of these veins generally consist of very finely granular quartz areas which gradually pass into those of sericite. Quartz also impregnates the sericite areas here and there in relatively large crystals, and high power shows the sericite flakes to be separated by minute granules of quartz. The larger impregnating grains contain inclusions of sericite and also minute fluidal cavities.

Sericite occurs in very small radiating aggregates. Its dirty appearance without crossed nicols suggests that it is associated with kaolin, and the bright interference colors seen -between crossed nicols are probably both from sericite and from relatively thick scales of kaolin. The irregular elongate shape of the sericite-kaolin areas indicates that they are derived principally from feldspars. A few prismatic sections of muscovite have their ends and edges bordered by small radiating bundles of sericite, suggesting that the muscovite has suffered incipient recrystallization; but transformation of a mineral without chemical change from one large into many. small grains through the action of a depositing solution seems rather unlikely. The association suggests equally well that the muscovite grain has attracted the sericite molecules to its edges, and this relationship seems more probable. It is, incidentally, proof that the sericite is of later development than the gneissic structure and the muscovite, and can not, therefore, be attributed to dynamic metamorphism.

In a few specimens a micaceous mineral of very low birefringence, resembling chlorite but optically negative, appears with the sericite and partly intergrown with it. It occurs in minute but distinct prismatic sections and shows no distinct tendency to a radiating habit.

A thin section of a less porous specimen than the last shows essentially the same characters, but only a small amount of original quartz is discernible. The sericite is more strongly impregnated with large quartz grains, and sericite inclusions in quartz are correspondingly more numerous.

The dense milky quartz in thin section (Pl. XIV, $B$ ) is found to be full of minute dirty specks, and, rarely, to include a small dirty aggregate of sericite and kaolin. The quartz, under low power, consists of a complex of large and minute grains. The minute ones act as a groundmass inclosing the large ones, and are traversed by numerous veinlets. The impregnating character of the veinlet walls is very distinct. Several excellent basal sections of quartz crystals are present; their edges, as well as those of large irregular grains, appear to have enveloped some of the adjacent granules-that is, to have grown at the expense of the groundmass. The whole section, when viewed 
PLATÉ XIV. 


\section{PLATE XIV.}

A. Photomicrograph of partly replaced alaskite. The two large areas marked " $q$ " are primary quartz, somewhat granulated and with marked undulatory extinction. The speckled central portion is sericite, with scattered grains of secondary quartz, after microcline and albite. Magnified 30 diameters. Nicols crossed. Section 138.

$B$. Photomicrograph of alaskite completely replaced by quartz. The large black central area is a basal section of quartz. The edges of large grains indicate growth by assimilation of small grains. The black specks in the large grains are chiefly gas cavities. The few minute sericite granules are not distinguishable. Magnified 30 diameters. Nicols crossed. Section 137. 


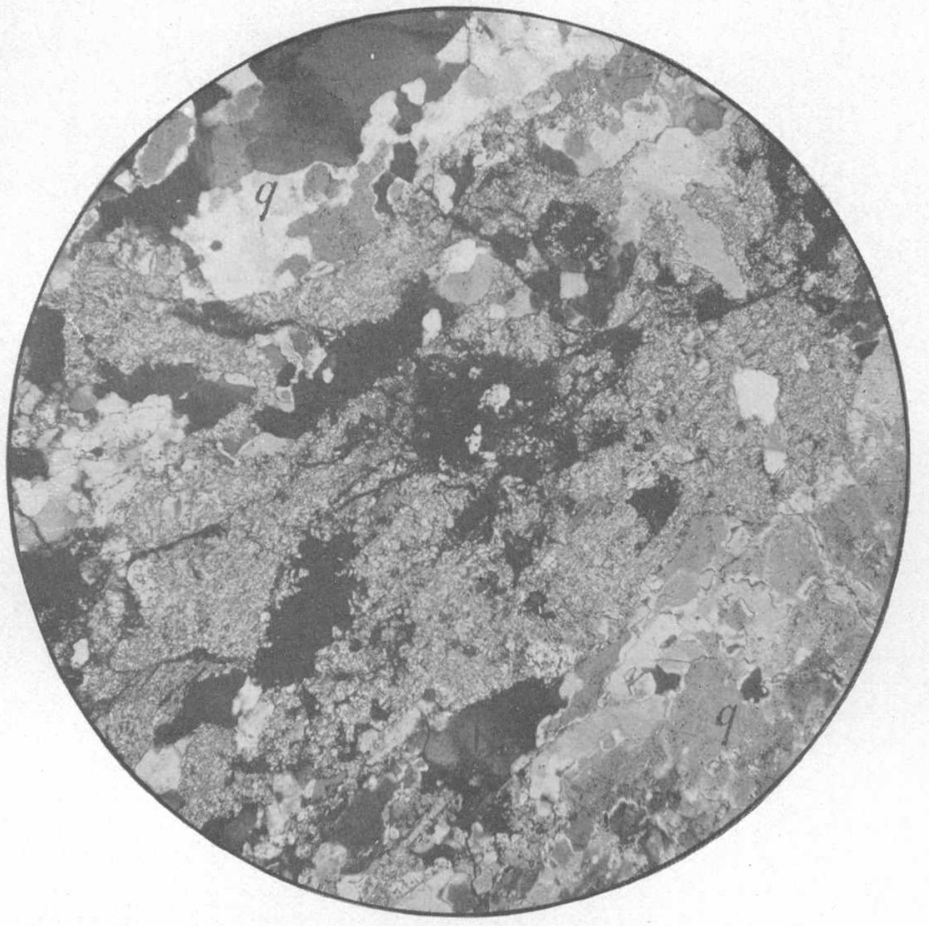

A.

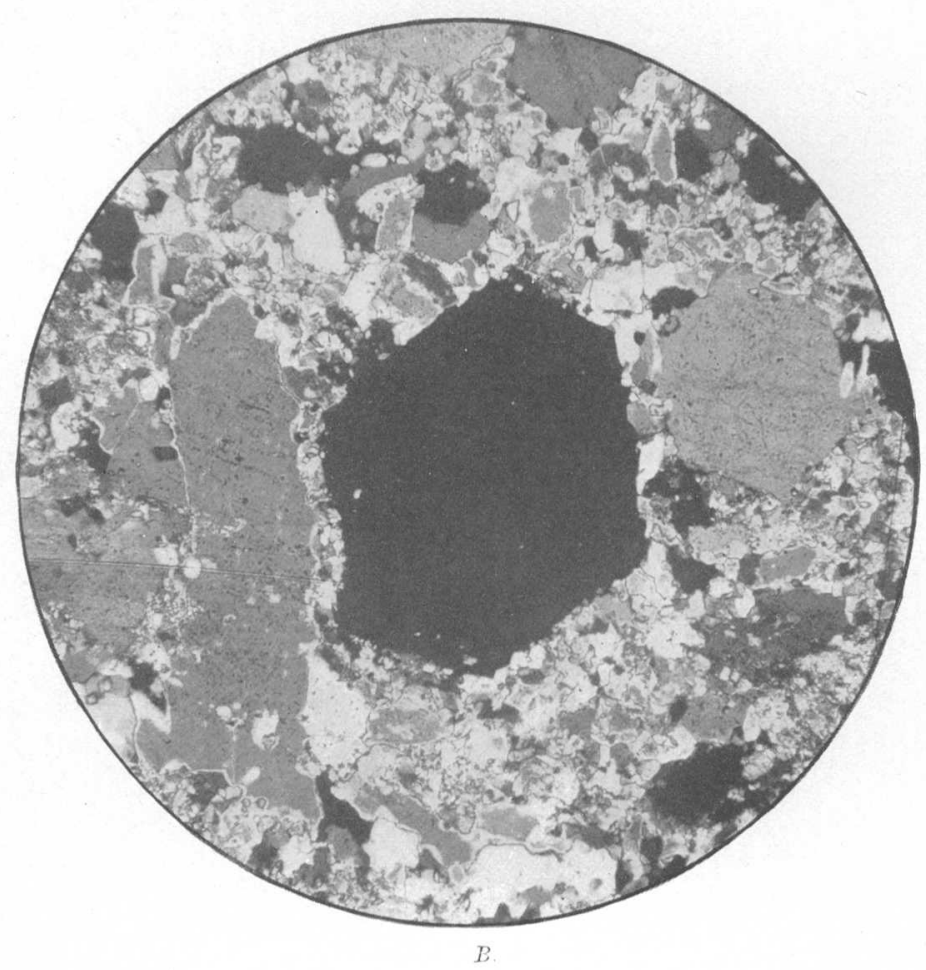


under high power, is seen to be sprinkled over with sericite and fluidal inclusions. Much of the sericite is grouped into clusters or irregular networks separated by rounded or elongated areas of clear quartz, suggesting that the original quartz grains, since recrystallized, had served as nuclei for the crystallization of the secondary quartz, which filled the original feldspar areas and included its alteration products. The development of sericite preceded that of secondary quartz, the latter tending to impregnate and finally to include the former. The scattered sericite-filled pockets (aggregates) mark the few points where replacement was not complete.

\section{REPLACEMENT.}

Loss of heat following the consolidation of the alaskite, aided by surface erosion, brought that rock into the zone of fracture, where it was subjected to stresses which produced jointing. These stresses, which were especially strong in a north-south zone passing through the position of the present quartz ridge, developed close vertical sheet joints with probably some faulting, which afforded access to pneumatolytic solutions from a deeper portion of the magma not yet fully consolidated. Numerous quartzose pegmatite veins resulted, including those south of the ridge and the feldspathic quartz vein noted at the northern base of the ridge. The higher the solutions ascended the more siliceous and highly fluid and less feldspathic they became. They not only filled the more or less open and continuous fissures, but permeated the microscopic cracks and even the minerals of the rock, robbing it of most of its alkali. The feldspar was converted more or less completely to sericite. At the same time quartz was deposited among the sericite particles, cementing them together. Where the deposition was brief in time and small in amount, the "intermediate" stage resulted with only very small granules of quartz; where deposition was more extensive and long continued, certain large crystals developed at the expense of the rest and the original feldspar areas became filled with quartz which enveloped what sericite was present and made a solid nonporous mass.

The open fissures, affording ample room for crystallization, became filled with quartz veins. Here, too, the amount of deposition varied from pockety veins with excellent comb structure in partly replaced rock to those of massive character, with no signs of comb structure remaining, in the completely replaced rock.

The fact that no comb structure has been noted in the most acidic pegmatite, including the feldspathic quartz vein above noted, may give room for the argument that these were formed when the wall rock was still in the zone of flowage, and that the parallel quartz veins of the Lantern Hill ridge were formed at a later date, after erosion had brought the rock into the zone of fracture. W. 0 . 
Crosby ${ }^{1}$ has thus distinguished between massive pegmatite quartz veins and quartz veins with comb structure in the eastern Carolina gold belt. In the present area the generally uniform strike and the limitation to one north-south zone of both the quartzose pegmatite and the quartz veins, as well as the sameness of the type of replacement in the wall rock of each, favor a common source for both. Where the solutions were more concentrated, as in the pegmatite veins, no comb structure is evident; but where they became more dilute not enough quartz was everywhere crystallized to fill the fissures or completely to replace the wall rock. It is also evident that where the solutions were too dilute to effect complete replacement they were efficient in permeating and decomposing the highly fractured wall rock. Kaolin may thus have resulted from feldspar that remained after sericitization had ended; but as kaolin is recognized as a product of the belt of weathering, it seems more likely that it has resulted from the action of meteoric water since the quartz mass was brought into the belt of weathering.

All stages of the replacement process can be seen in the Lantern Hill ridge and also at Griswold. Lantern Hill proper, with its massive milky quartz, represents the process practically complete. The remainder of the ridge represents intermediate stages in which traces of the feldspar are more or less distinct. The solidity of this partly replaced rock depends on the amount of impregnation and the degree to which it is bound together by the ramifying veinlets. In most cases it has resisted weathering, but at the Silex mine the network and impregnation have not been sufficient to prevent crumbling. No definite evidence of faulting and attendant crushing at the Silex mine was noted.

The pyrite, which is present in small amount, is thought to be due to the union of iron in the scarce magnetite and biotite of the alaskite with sulphur in the ascending solution. As no quantitative comparisons were made to prove this statement, it may be that the pyrite is too great in amount to have been derived wholly from the 1.51 per cent of iron oxides in the alaskite, and must have been introduced in part, or wholly, by the ascending solutions; but the prominence of pyrite in the biotite-quartz schist inclusion on Lantern Hill, richer in iron than the alaskite, favors the conclusion reached.

PRESERVATION OF THE QUARTZ-BIOTITE SCHIST INCLUSION.

The apparent preservation of the quartz-biotite schist in the midst of the almost completely replaced alaskite is a striking feature, especially as the former rock in the vicinity has suffered far more from

1 Crosby, W. O., Trans. Am. Inst. Min. Eng., vol. 38, 1908, pp. 852-853. Also Tech. Quart., vol. 20, No.3, 1907, pp. 282-283. 
weathering than the latter. Chemical alteration in the schist took place, converting the biotite to chlorite, a little sericite, and considerable pyrite; but the chlorite has served to preserve the schistose structure. Not enough feldspar was present to alter the appearance of the rock by its replacement.

\section{MINERAL CONTENT.}

The Lantern Hill quartz is, genetically, an extreme form of greisen with quartz as the only important mineral, and mica very inconspicuous. Typical greisen is described by Rosenbusch ${ }^{1}$ as "tin-orebearing" granite in which feldspar has been replaced by quartz and mica (mostly lithium bearing), pneumatolytic minerals, notably cassiterite, those containing $\mathrm{F}$ and $\mathrm{B}_{2} \mathrm{O}_{3}$ (topaz, fluorite, fluorapatite, tourmaline, and axinite), the tungsten minerals, wolframite and scheelite, rutile, and sulphides and arsenides of various metals. This list of minerals, when compared to those found in the simple Lantern Hill quartz, shows that the pneumatolytic portion of the Sterling batholith was deficient in mineralizers. The only constituents besides water which have left evidence of their presence are $\mathrm{SiO}_{2}$, a little $\mathrm{F}$ (in the sericite), and some $\mathrm{S}$ (in pyrite). The presence of kaolin associated with the sericite, marking the former presence of unreplaced feldspar, is evidence of the absence of $\mathrm{B}_{2} \mathrm{O}_{3}$ and the scarcity of $\mathrm{F}$, which would presumably have formed tourmaline and topaz, or more sericite, respectively. It also points to the absence of $\mathrm{K}_{2} \mathrm{O}$ from the pneumatolytic constituents, as the scarcity of sericite speaks for the partial removal rather than the introduction of that constituent. This evidence of extremely simple composition agrees with that offered by the pegmatite (p. 127).

The absence of metals other than iron and a trace of gold $^{2}$ is in marked contrast to their abundance in metalliferous quartz veins of the West which have been attributed to pneumatolytic origin. Most of the mineralizers above noted, besides several others, were important in the formation of these deposits. It is therefore certainly curious and striking that Lantern Hill, one of the largest quartz masses known, should be of so simple and totally barren a character. In view of the fact that many metalliferous vein deposits are now regarded as of magmatic origin, this lack of metals and mineralizers in othe pneumatolytic portion of the Sterling batholith and the general absence of paying vein deposits in the portion of southern New England, which the batholith is known to underlie, are noteworthy.

\footnotetext{
1 Elemente der Gesteinslehre, 1901, p. 92.

2 Alonzo Main, foreman of the Silex mine, told the writer in 1905 that the crumbly quartz of the mine assayed 25 cents per ton. Portions of the rock containing a conspicuous amount of pyrite might give a somewhat higher value, but the formation as a whole could not be said to contain much more than a trace of gold.
} 


\section{OTHER QUARTZ MASSES IN THE REGION.}

At the northern summit of Swantown Hill, North Stonington, and also on the hill just west of it, are small quartz masses similar to that of Lantern Hill, save that the replaced rock was of aplitic texture. The Swantown Hill occurrence was prospected for gold, and an assay made for Mr. Thomas Hewitt, of North Stonington, showed a trace of the metal. The exact extent of both of these deposits was concealed by glacial drift.

Other quartz deposits occur outside the area in the eastern crystallines of Connecticut and in Rhode Island, but no detailed reports on them have been published. The largest deposit, at Diamond Hill, in Cumberland, R. I., has been visited by the writer, and is generally similar in form to the Lantern Hill quartz mass, save that the replaced wall rock is a felsite. The Diamond Hill occurrence has been briefly described by Woodworth, ${ }^{1}$ who attributed its origin to hot springs connected with the volcanic activity which produced the felsite, and who regarded it as of early Carboniferous age. It is also mentioned by Emerson and Perry, ${ }^{2}$ who agree with Woodworth's conclusions.

\section{PROBLEMS OF STRATIGRAPHIC AND PETROGRAPHIC CORRELATION.}

In a small area like the one under consideration, where the sedimentary rocks are metamorphosed and no fossils can be found, it is impossible to determine definitely the geologic ages of the formations except by tracing them into regions where their relations with fossiliferous rocks can be accurately determined. The attempt to trace the rocks of this area into regions of known geologic age gives rise to certain problems along stratigraphic and petrographic lines.

\section{CORRELATION OF SEDIMENTARY ROCKS.}

The metamorphic sedimentary rocks of the area comprise a quartzite, a gray quartz-biotite schist, a fine-grained hornblende schist, a feldspathic schist or gneiss, and a dolomite, all of which appear to be conformably related.

On the "Preliminary geological map of Connecticut" 3 all these rocks except the quartzite were mapped as Putnam gneiss. This gneiss has been traced northward into Massachusetts, where it is represented by the Bolton gneiss. This rock at Worcester, Mass.; has been shown by Perry and Emerson ${ }^{4}$ to lie conformably with quartzite and fossiliferous phyllite of known Carboniferous age, and is regarded by them as Carboniferous.

\footnotetext{
1 Woodworth, J. B., Mon. U. S. Geol. Survey, vol. 33, 1899, p. 155.

2 Emerson, B. K., and Perry, J. H., Bull. U. S. Geol. Survey No. 311, p. 56, 1907.

3 Gregory, H. E., and Robinson, H. H., Bull. Connecticut State Geol. and Nat. Hist. Survey No. 7, 1906.

- Perry, J. H., and Emerson, B. K., Geology of Worcester, Mass., 1903, p. 129.
} 
As far as preliminary surveys in Connecticut have determined, the Putnam gneiss is conformable on the west with the "Scotland schist," which in turn has a gradation contact with the "Hebron schist" to the west of it. If all these relations have been correctly determined, a large part of eastern Connecticut must be of Carboniferous age; but the whole problem is a complex one, as pointed out by Gregory, ${ }^{1}$ and is far from being definitely settled.

The problem in areas west of the Putnam gneiss area may be solved by proof of conformable and grading contacts, but the problem to the east is of a very different nature. The Sterling granite gneiss, which is intrusive into the metamorphic sedimentary rocks, is believed by the writer (see p. 135) to extend eastward 15 miles to the Narragansett Basin in Rhode Island. The sedimentaries of the Narragansett Basin determined as Carboniferous by Shaler, Woodworth, and Foerste ${ }^{2}$ are described as lying unconformably on the bordering crystalline rocks and as being derived from them. Thus, according to one view, the supposed Carboniferous of eastern Connecticut is a part of the metamorphic series and is cut by the Sterling granite gneiss; according to the other, the Carboniferous of Rhode Island is younger than the same granite.

A few statements in the Narragansett Basin monograph suggest that further petrographic work, especially in the crystallines along the western border of the basin, may lead to some solution of the problem. Conglomerate beds near Wickford, R. I., are said to be metamorphosed into gneiss and to have completely lost their original character. ${ }^{3}$ Pegmatite dikes are intruded into the Carboniferous rocks within 2 miles of the western border, and where most abundant, around Boston Neck and Tower Hill, the conglomerate and sandstone are most severely metamorphosed. ${ }^{4}$ The authors incline to regard the pegmatite as having been derived from a hidden source and as not being related to the granite along the border; but they admit that one dike southwest of Wesquage Pond "appears to connect with pre-Carboniferous granites as though the latter were in reality postCarboniferous." 5 Their chief objection to regarding the granite as post-Carboniferous is that post-Carboniferous granites are not known to exist in the region investigated, and the subject is dismissed with the statement that the conditions are perplexing and require further study.

It seems, from these descriptions and from brief observations made by the writer in the spring of 1908, that metamorphism and granite intrusion have taken place in the Carboniferous of the Narragansett Basin along its western border, though not nearly so extensively

1 Manual of geology of Connecticut: Bull. Connecticut Geol. and Nat. Hist. Survey No. 6, 1806, p. 114.

2 Geology of the Narragansett Basin: Mon. U. S. Geol. Survey, vol. 33, 1899.

Idem, p. 61 .

Idem, p. 28.

Idem, p. 245. 
as in the supposed Carboniferous of eastern Connecticut. The correlation of the two areas; then, rests upon the identification of the intrusives as parts of the same batholith and the proof that both areas were metamorphosed during the same period. This work will be essentially a continuation of the Narragansett Basin work, as the authors of that monograph state in the preface ${ }^{1}$ that the crystalline rocks west of the basin have not been studied and are left to be worked out by the petrographer.

The principal working hypotheses which suggest themselves for further study are as follows:

1. The unconformity of the western border exists as interpreted in the monograph cited, and the supposed Carboniferous of eastern Connecticut is really pre-Carboniferous. A new correlation with the Carboniferous of Worcester, Mass., will then be necessary. ${ }^{2}$

2. The basin rocks are separated from the crystallines by a strike fault, as is supposed to be the case along the eastern border of the Triassic basin of central Connecticut.

3. The apparent unconformity between the basin and bordering crystallines is in reality an igneous contact, and marks the eastern limit of recrystallization during metamorphism. The more rapid erosion of the less metamorphosed and injected rocks has here produced a recent topographic basin, which may not coincide with the basin in which the Carboniferous strata were deposited.

4. Intrusions may occur in both areas, and these areas may be separated by a pre-Carboniferous protaxis. Thus far there is nothing definite to suggest the existence of such a protaxis.

The writer has made a beginning of this study and hopes to complete it in the near future. ${ }^{3}$

\section{CORRELATION OF IGNEOUS ROCKS.}

The question of the extent of the Sterling granite gneiss and its correlation with the different isolated granite masses in the region needs no further mention. The character and extent of the finegrained Westerly granite (see p. 135), which is intrusive into the Sterling, and its relation to the period of metamorphism furnish further points of interest. A comparative study of the similar quartz masses of Diamond Hill, R. I., and Lantern Hill, Conn., especially with respect to their relations to neighboring granitic formations, may afford the clue to further correlation.

Study and comparison of gabbro and diorite masses which occur at several localities in southern New England may afford further

\footnotetext{
1 Op. cit., p. xviii.

2 Idem, p. 245.

a Since he flnished writing this report, in 1908, the writer has completed his study along the western border of the Narragansett Basin and has reached conclusions essentially the same as those embodied in the third hypothesis. See paper Intrusive granites and associated metamorphic sediments in southwestern Rhode Island: Am. Jour. Sci., 4th ser., vol. 29, 1910, pp. 447-457.
} 
interesting results. In short, the region between the two Carboniferous areas of southern New England seems to hold the clue to many interesting problems which now remain unsettled, and it is the writer's hope to have a share in solving them.

\section{SUMMARY.}

The area described has a glaciated topography typical of southern New England - the hills for the most part of elliptical outline, the valleys filled with Pleistocene lacustrine and fluviatile deposits, and the drainage in many places diverted from its preglacial channels.

Areal geology. - The bedrock formations comprise metamorphic sedimentary rocks, gabbro and granite intrusions, and an immense mass of quartz. The metamorphic sedimentary rocks, assigned provisionally to Cambrian and Carboniferous age, include quartzite, quartz-biotite schist, hornblende schist, black pseudoporphyritic schist (kinzigite), and dolomite, each in apparently conformable relations to adjacent formations. The gabbro, comprising two principal and several minor varieties, forms a roughly oval main mass in the central part of the area, with a few outliers and several associated intrusive sheets, especially in the western part. The granite, comprising three varieties, lies mostly in the southern part and is represented by numerous intrusive sheets elsewhere save within the gabbro area.

Structural geology.-Schistosity in the sedimentary rocks is, as far as observed, everywhere coincident with the strike and dip of the bedding. This constant relation is attributed to the sliding or "flowing" of bed over bed during the development of overturn folds. Undulations, for the most part miniature overturns, with axes normal or oblique to those of larger folds, are very prevalent and are attributed to minor movements set up during the period of folding. Minor folds are numerous and, as shown in figures 4 to 7 , are chiefly overturns. Their number and character are ample evidence of the complexity of the folding. Major folds within the area are not clearly indicated; overturned synclines are indicated in the eastern and western parts of the area, but there is not sufficient convincing evidence to prove their existence beyond dispute. The most striking feature of folding within the area is its relation to the central gabbro mass. This rigid mass acted, with respect to the schists, during folding, much as a large resistant pebble in a relatively plastic matrix of a mashed conglomerate. The secondary strains induced by its deformation, acting in conjunction with the primary folding movement of the region, tended locally to develop abnormal folding. While the deformation of the gabbro was alone insufficient to account for the actual extent of local folding, it was sufficient to determine the paths of the granite intrusion that accompanied the folding; 
the additional influence of this intrusion was sufficient to produce all of the local deformation.

In the Preston gabbro, the shapes of both the main mass and the outliers favor their interpretation as sills, or sill-like forms. The strikes and dips around the main mass indicate that its intrusion produced a domal uplift. The several varieties of gabbro are probably due to magmatic segregation.

Consideration of the effects of regional metamorphism indicates that the gabbro had been intruded and cooled prior to the period of compression. The effects of contact metamorphism by which adjacent and included rock was converted to a basic hornfels also point to intrusion before regional metamorphism. The hornfels grades away from the gabbro into hornblende schist.

The chief varieties of Sterling granite gneiss are three in number. The porphyritic and alaskite varieties were intruded as sills. The normal granite exposed in the southern part of the area is too extensive to be regarded as forming sills, but the occurrence in it of schist inclusions with their contacts parallel to the foliation indicates that erosion has removed formerly existing sills, leaving only a few roots, and has exposed the top of the batholith proper. The numerous sills in the region probably formed the advance guard of the upwardworking batholith, which replaced sinking blocks that had been enveloped by the sills. The distribution and size of the sheets, large and small, suggest that the batholith underlies the whole area, if not a much greater area, and that the surface of the batholith proper slopes downward to the north. True dikes are scarce.

The porphyritic and normal varieties of the Sterling granite gneiss are textural variations of one period of intrusion, the former characterizing many sheets, the latter the batholith proper. The alaskite, in large part at least, is of a slightly later period. Pegmatite dikes younger than the alaskite mark the final period of intrusion. The first period was evidently during the period of folding, the second marked its closing stage, and the last, for the most part, took place after regional movement had ceased.

Contact metamorphism due to the granite consists of a thorough injection of biotitic schist accompanied by some pneumatolytic action. The schist has been converted into a highly epidotic rock, which forms small bands or lenses separated by highly quartzose granitic stringers.

Structural features common to the area as a whole are joints, faults, and veins. The joints comprise two principal systems, one northsouth and one east-west, with minor poorly defined systems in diagonal position. They are believed to have originated shortly after the period of folding, after the region had come into the zone of fracture, but not later than the pneumatolytic stage of the granite intrusion. The relation of joints to stream courses shows that 
jointing is only of minor importance in the development of the largest streams of the district, though of chief importance in determining the courses of the smallest streams.

Well-marked faults of any important size are not found in the area, but the lack of continuity of strata suggest faults at a few places. The most noteworthy, at Ashwillet, along the southeastern contact of the gabbro, is regarded as an intrusion fault developed by the gabbro. Another possible fault, where Broad Brook crosses the western edge of the gabbro, also may be due to intrusion, or may postdate the regional metamorphism. If the latter is the true interpretation, the fault follows the least conspicuous of the minor joint systems.

Of the quartz veins only those of pneumatolytic origin deserve special consideration. Chlorite veinlets in gabbro occur in great abundance.

Petrography.-The quartzite, for the most part typical, but with minor variations containing lime-magnesia silicates and labradorite, is interpreted as a metamorphic quartzose sandstone slightly calcareous in places. The quartz-biotite schist, with its several variations, hornblendic, calcareous, and feldspathic, is regarded as originally a more or less arkose sandstone. The hornblende schist, composed chiefly of hornblende and labradorite, and chemically similar to gabbro, varies from a typical schist to typical slate and hornfels in structure, and contains small interbeds of quartzose, graphitic, and calcareous rock. It is interpreted from combined petrographic and geologic evidence as a metamorphosed basaltic tuff. The black pseudoporphyritic schist has the mineral composition of kinzigite, but differs from the type rock in its pronounced pseudophenocrysts of metamorphic albite-oligoclase and garnet. Its obscure origin is discussed at some length and is interpreted as the metamorphic product of a previously altered basaltic tuff. The dolomite varies from the pure rock to beds composed largely or entirely of lime-magnesia silicates. Attention is called to the predominance in the sedimentary rocks of plagioclase and to its interpretation in some places as recrystallized clastic grains and in others as of purely metamorphic origin.

In the porphyritic gabbro the order of crystallization is (1) feldspar, (2) diallage accompanied or closely followed by ilmenite. Pyrite appears to be contemporaneous with magnetite. Secondary brown hornblende borders, mostly between diallage and labradorite, are interpreted as reaction rims developed prior to deformation. Certain chlorite-magnetite (?) aggregates are due to possible alteration of ilmenite. Uralitization of diallage is described and traced from its beginning to an extreme development as compact blades of hornblende in highly schistose rock. This change was accompanied by granulation of feldspar and in some places by development of 
typical saussuritization. It is possible that the relation of saussuritization to uralitization may have been complementary.

In the norite phase the order of crystallization was evidently (1) bronzite, (2) labradorite, (3) diallage, (4) titaniferous magnetite and pyrite. The bronzite is characterized by reaction rims of uralite against labradorite and is itself considerably altered to talc. The other minerals present the same general characters as in the porphyritic gabbro.

The olivine gabbro phase is closely similar in order of crystallization and mineral characters to the norite, with olivine substituted for bronzite. The olivine, like the bronzite, is characterized by hornblendic reaction rims and alteration to talc. Secondary magnetite occurs with the talc. Meager evidence suggests that talc was formed in places which suffered practically no deformation and uralitization, and that the olivine was completely uralitized where metamorphism was more severe. Both norite and olivine gabbro repre-1. sent portions of the magma where $\mathrm{MgO}$ predominated over the $\mathrm{CaO}$ available for pyroxene, but the norite, in the upper portion of the mass near the quartz-hornblende gabbro, is the higher in $\mathrm{SiO}_{2}$.

The pyroxenite phase simply marks a segregation of the ferromagnesian portion of the gabbro magma. It is cut by complementary dikes of plagioclase pegmatite. Basic pegmatite in dikes and segregations are of common occurrence in the porphyritic gabbro, as are local diabase dikes, identical in all but coarseness of grain with the gabbro. The diabase is considered due to intrusions from a lower portion of the magma which remained fluid after the upper portion had solidified and suffered fracturing.

The quartz-hornblende gabbro is a little higher in $\mathrm{SiO}_{2}$ and iron than the porphyritic gabbro. What pyroxene remains is augite rather than diallage. Its hornblende is probably in part primary and in part secondary. Ilmenite has the same characters as in the other types, being younger than or intergrown with the primary silicates. Primary quartz is intergrown with all the silicates, and is apparently contemporaneous with ilmenite. Apatite is a constant characteristic. Imperfect field evidence indicates a gradation between the quartz-hornblende and porphyritic types.

Minor variations of the quartz-hornblende gabbro include small segregations containing diallage phenocrysts, quartz anorthosite with complementary hornblendite, basic pegmatite and aplite, and oligoclase granite. The latter, carrying 73 per cent $\mathrm{SiO}_{2}$, grades into the quartz-hornblende gabbro and forms local intrusions into it.

The gabbro outliers and amphibolite sheets correspond to the gradational rock between porphyritic and quartz-hornblende gabbro.

The chemical composition and differentiation of the rock types favors the conclusion that the minor phases are due to local segregation and that the two principal varieties are due to an incomplete 
differentiation prior to crystallization. The ultimate product would presumably have been a principal magnesia-lime portion, consisting essentially of pyroxene and (or) olivine and basic plagioclase, and two minor portions complementary to each other-one a silicaalkali phase (the oligoclase granite), the other a supposed titanic iron-ore phase. The process had so far progressed that the constituents of these minor phases had collected into the upper portion of the mass and were beginning to segregate into distinct bodies when consolidation took place. The result of this arrested differentiation was the quartz-hornblende gabbro.

The Sterling granite gneiss is fairly typical of gneissoid biotite granite in general. Its chief features lie in the character and significance of the degree of granulation in feldspar and quartz of the several varieties. This indicates that the normal and porphyritic granites were intruded and crystallized during the height of the compression period, the alaskite during the closing stages, and the pegmatite in the alaskite after compression and movement had practically ceased. The age of intrusion is supposed to be that of the Appalachian revolution. It is possible, judging from the known thickness of the nearest Carboniferous strata, that the granite sheets and the zone of flowage reached within 3 , or even 2 , miles of the surface. Comparison of the Sterling with other granites in Connecticut and Rhode Island indicates that the Sterling batholith extends from Narragansett Bay, R. I., westward to the Connecticut Triassic area, and northward along the eastern State boundary into Massachusetts. Its northward extent along the Triassic border as far as Middletown, Conn., may be expressed in the mass to which Gregory has given the name Maromas granite gneiss.

The Lantern Hill quartz in North Stonington has originated from a more or less complete replacement of alaskite by quartz during the pneumatolytic stage of granite intrusion. Missing links in the chain of evidence are supplied by a small deposit of similar character near Glasgo village in Griswold. Although Lantern Hill is one of the largest quartz masses known, its simple mineral composition and lack of valuable metals are striking when compared to deposits of similar origin in the West. Similar deposits occur in southern New England, the largest being that of Diamond Hill, R. I.

The correlation of the Carboniferous of the Narragansett Basin with the supposed Carboniferous of the area is a problem for the future. The vital point appears to be the correlation of the granites of the two districts, one granite being regarded by Shaler, Woodworth, and Foerste as older than the sediments of the Narragansett Basin, the other (the Sterling granite gneiss) being clearly intrusive into the schists of the area. Further correlation and comparative study of the several igneous rocks of the region is likely to afford interesting results. 



\section{INDEX.}

A.

Acknowledgments to those aiding.

Alaskite, character and chemical composition of . ..................... 123-126

Alaskite, complete replacement of, photomicrograph of................. 142

from Terra Cotta Range, Alaska, analysis of ........................

gneissoid variety of, anaiysis of ..........

impregnated by quartz, photomicrograph showing ......................

quartz grain in, granulation and weld fractures of, figure'showing .....

relation of Sterling granite gneiss to regional metamorphism shown in 129-130

sliced microcline in, figure showing ....... 120

Alaskite areas, character and distribution of.. $\quad 36$ Alaskose-liparose, petrographic character and chemical composition of ....... 123-126

Albite twinning, resemblance to, of undulatory extinction of quartz, figure showing.

Allanite, in quartz-biotite schist, occurrence of

Alsbachose, occurrence and petrographic character of ....................

Amphibole sheets, and pegmatite, folding inferred from, figure showing........

outlying, petrographic character of .... 112-113

relations of, to gabbros.............. 113-119

Apatite, in oligoclase granite, occurrence of... 110

A plite, analyses of...................... 123

in quartz-hornblende gabbro, occurrence of................... 107, 109

Areal geology, account of ................ 15-24

summary of ...................... 149

Asbestos veins, in gabbro, occurrence of. . . . . 53-54

Ashwillet intrusion fault, general features of. . 51-52

Augite, in quartz-hornblende gabbro, occurrence of.

in quartz-hornblende gabbro, photomicrograph of.................. 104

Auvergnose, petrographic character of...... 102-111 Auvergnose-hessose, petrographic character of. 94-96

B.

Barrell, Joseph, assistance of Basic pegmatite, in quartz-hornblende gabbro, occurrence of...............

Basic pegmatite phase, of porphyritic gabbro, characteristics of................ 101

Basic slate, petrographic character of ....... 63-65

Biotite, occurrence of, in amphibole sheets.... 113 occurrence of, in porphyritic gabbro...... in quartz-hornblende gabbro.........

Black pseudoporphyritic schist, character and distribution of
Black pseudoporphyritic schist, petrographic character of. . ................ $68-76$

Sce also Kinzigite.

Broad Brook fault, general features of........ 52

Bronzite, occurrence of, in norite phase of porphyritic gabbro ............ 95-96

Brown hornblende, rims of, between diallage and labradorite, photomicrograph of............................

See also Secondary brown hornblende.

Bytownite, occurrence of, in porphyritic gabbro........................

C.

Cape Ann, Mass., aplite from, analysis of...... 123

Chlorite, in oligoclase granite, occurrence of ... 110

veins of, in gabbro, occurrence of....... 53-54

Chlorite-magnetite aggregates, occurrence of, in porphyriticgabbro........... 88

photomicrograph of................... 90

Compression, effect of, on schist and gabbro, figures showing ................ 31

Conanicut Island, R I., porphyritic granite from, analysis of .............. 123

Cofitact metamorphism, due to Preston gabbro, account of................ 39-43

due to Sterling granite gneiss, account of. . 43-44

Correlation, general problems of ............ 146-149 of igneous rocks, conclusions regarding. 148-149 of sedimentary rocks, conclusions regarding .................... 146-148 Crumplings in schist, figure showing......... 25

\section{D.}

Deformation, relation of intrusion of Ster-

$$
\text { ling granite gnelss to .......... 127-129 }
$$

Diabase dikes, character of............. 101-102

Diallage, occurrence of, in porphyritic gabbro. 80 , $96,97,98$

phenocryst of, photomicrograph showing. 42 Diallage gabbro segregations, in quartz-hornblende gabbro, occurrence of..... 108

Dip and strike, observations of, map showing..................... In pocket. Dissolution holes, origin of . ............... 54 plate showing..................... 56

Dolomite, character and distribution of..... 20-21 North Stonington bed of, restored section of, figure showing............. 27 petrographic character of ................ $76-78$

Drainage, general features of .............. 13-14

Drushel, W. A., work of ...................

E.

Epidote gneiss, in quartz-biotite schist, occurrence of . .................... 61-62

photomicrograph of................... 42

Erosion, special features of .............. 54 
F.

Page.

Faulting, character and distribution of ...... 50-53 Feldspar, inclusions of dustlike gabbro in, figure showing.

Folding, effect of, on gabbro, figure showing. generálized strike lines showing character of ...................... In pocket.

inferred from relations of pegmatite and amphibole, figure showing...... $\quad 26$

nature and effects of .................. 25-33

Folds, arrangement of ................... $\quad 29$

major, character of . . .................. 28-29

minor, examples of .................. 26-28

origin of ........................... $30-33$

G.

Gabbro, asbestos and chlorite veins in...... 53-54 effect of erosion on.................... 54 effect of folding on, figure showing...... 30 inclusion of hornfels in, figure showing... $\quad 40$ inclusions of, in feldspar, figure showing. $\quad 85$ intrusion of, effect of, in folding........ 30-32 mashing of, photomicrographs showing.. 90,92 outliers of. 112

relations of, to amphibole sheets....... 113-119

result of eastward compression on, figure showing......................

saussuritization of, photomicrograph showing ......................

See also Olivine gabbro; Porphyritic gabbro; Preston gabbro; Quartzhornblende gabbro.

Garnet, in oligoclase granite, occurrence of... 110

Geology, areal, account of............... 15-24 areal, map showing. ............. In pocket.

historical, account of. .. 57-58

of Lantern Hill, account of .......... 135-149

structural, account of................. 24-54

summary of .................... 149-153

Gneissoid alaskite, from Ledyard, Conn., analysis of

See also Sterling granite gneiss.

Gneissoid porphyritic granite, from Griswold, Conn., analysis of. .............

See also Sterling granite gneiss.

Granite, dike of, crossing syncline in hornblendic kinzigite, figure showing.

effect of intrusion of, in folding.

gneissoid porphyritic variety of, analysis of ...........................

hornblendic, character of .............. intrusions of, structural interrelations of.

See also Oligoclase granite; Porphyritic granite.

Granite gneiss. See Sterling granite gneiss.

Gregory, H. E., assistance of.

Griswold, Conn., gneissoid porphyritic granite from, analysis of . ............

thickness of porphyritic granite sheet at, figure showing.

Griswold quartz mass, character and position of . . ..................... 136-137

Gulliver, F. P., assistance of................

\section{H.}

Hills, general character of .............. 12

Historical geology, account of.
History, of geologic explorations, account

Hornblende, filled with secondary quartz, photomicrograph of ........... 104

in quartz-hornblende gabbro, occurrence of ........................ 105-106

See also Brown hornblende; Secondary brown hornblende: Secondary green hornblende.

Hornblende schist, character and distribution of ..................... 18-20

origin of ........................ $66-67$

petrographic character of............62-63 Hornblendic granite, petrographic character of ..................... 126

Hornblendic kinzigite, granite dike crossing syncline in, figure showing.......

Hornblendic variety of basic hornfels, character of........................

Hornfels, inclusion of, in gabbro, figure showing........................

subdivisions and character of basic variety of ....

I.

Igneous intrusions, general features of....... 33-44 Igneous rocks, character and distribution of.. 21-24 correlation of ..................... 148-149 Ilmenite, in oligoclase granite, petrographic character of................... 110

in quartz-hornblende gabbro, photomicrograph of................. 104

occurrence of, in amphibole sheets...... 113

in porphyritic gabbro.......... 87-88,96,98

in quartz-horn blende gabbro........ 107

poikilitic development of, in olivine gabbro and pyroxenite, photomicrographs showing................

Intrusion, of Sterling granite gneiss, relation of, to deformation........... 127-129

Intrusions, effect of , on folding............... 30-33 igneous, general features of............ 33-44

\section{J.}

Johannsen, Albert, assistance of............ 9

Joints, directions and distribution of......... 44-47 directions of, plate showing............ 44

table showing................... 46 distribution of, curve showing.......... 45 observations of, map showing ...... In pocket. origin of ......................... 47-48 relation of, to stream courses........... 48

\section{K.}

Kinzigite, character and distribution of...... $\quad 20$ chemical analyses of................. 73 dike crossing, figure showing ............ 37 origin of....................... 74-76 petrographic character of ............. 68-76 plate showing..................... 70 variations of ....................... $73-74$

L.

Labradorite, occurrence of, in amphibole sheets...................... 113 occurrence of, in porphyritic gabbro...... 84-87 95,88 
Page.

Lantern Hill, geology of

135-149

Lantern Hill quartz, character and distribution of...................... 24

geology of . . . . . . . .

mineral content of.................. 145

occurrence and petrographic character of........................ 137-145

preservation of quartz-biotite schist intrusion in.................... 144-145

replacement in.................. 143-144

Ledyard, Conn., gneissoid alaskite (Sterling - granite gneiss) from, analysis of.

Leucoxene, in oligoclase granite, occurrence of

Lime-silicate rock, schist in fold of, figure showing.

\section{$\mathrm{M}$}

Metamorphic sedimentary rocks, petrographic features of ....................58-78

Metamorphism, deformation due to......... 38-44

in porphyritic gabbro, effect of.......... 93-94

Mica, in oligoclase granite, petrographic character of

Microcline, in alaskite, figure showing........

Milky quartz, photomicrograph showing....

Mineral content, of Lantern Hill quartz mass, discussion of...................

Montana, aplite from, analysis of ...........

Moosup quadrangle, Conn., parts of, topographic, geologic, and outcrop maps of In pocket.

N.

New London County, Conn., parts of, topographic, geologic, and outcrop maps of .................. In pocket.

Norite phase, of porphyritic gabbro, petrographic character of ........... 94-96

North Stonington, Conn., folding in limekiln at, flgures showing............ 27

quartz deposits near.................. 146

Norway, aplite from, analysis of.......... 123

$$
0 \text {. }
$$

Ohms, F., work of..

Oligoclase, in oligoclase granite, petrographic character of ....................

Oligoclase granite, occurrence and petrographic character of ..............

occurrence of leucoxène in...............

relation of, to quartz-hornblende gabbro.

Olivine, occurrence of, in porphyritic gabbro.

Olivine gabbro, with secondary brown hornblende, photomicrograph of......

Olivine gabbro phase, of porphyritic gabbro, petrographic character of ........ 96-98

Outcrops, locations of, map showing . . . In pocket. Outliers, character and distribution of..... 112-113

\section{P.}

Pegmatite, and amphibole sheets, folding inferred from, figure showing...... 26 characteristics of basic variety of ..... 101, 109 occurrence and mineral composition of... 127

Petrography, correlation problems in respect to. 146-149
Page.

Petrography, discussion of............... 58-135

summary of ...................... 151-153

Pirsson, L. V., assistance of............... 9

Pitting, of gabbro surface, effect of erosion on. 54

Poikilitic diallage phenocryst, photomicro-

graph of ...................... 42

Ponds, origin of .................... 14

Porphyritic gabbro, basic pegmatite phase of. 101 dissolution holes in.................... 54 norite phase of ...................... 94-96

normal phase of.................... 79-94

olivine gabbro phase of............... 96-98

petrographic character of ............. 79-102

pyroxenite phase of . ................ 98-101

relation of, to quartz-hornblende gabbro. 108

Porphyritic granite, from Conanicut Island, R. I., analysis of..............

relation of Sterling granite gneiss to regional metamorphism shown in. 129-130

Porphyritic granite gneiss areas, character and distribution of ..............

Porphyritic granite sheet, at Griswold, Conn., thickness of, figure showing......

Prentice Mountain, mineral composition of rocks near................... 111

Preston, Conn., area, location of ............. 11

location of, index map showing......... 11

topographic, geologic, and outcrop maps

of .................... In pocket.

Preston gabbro, character and distribution of. 21-23 contact metamorphism due to......... 39-43 differentiation of members of ........... 114 intrusion of ........................ 33-34 norms of members of................ 114 petrographic character and types of..... 78-119 porphyritic type of, petrographic features of ....................... 78-102 quartz-hornblende type of, petrographic features of................. 102-113 regional metamorphism of .............. 38-39 relations of types of ............... 113-116

Seealso Gabbro; Olivino gabbro; Porphyritic gabbro; Quartz-hornblende gabbro.

Principal valleys, relation of joints to....... 48-49

Publications, on geology of Preston region, list of ...................... 14-15,

Pyrite, occurrence of, in porphyritic gabbro... 88, 96 occurrence of, in quartz-hornblende gabbro....................... 107

Pyroxenic basic hornfels, photomicrograph of. $\quad .54$ Pyroxenic variety of basic hornfels, character of ......................... 65-66

Pyroxenite, photomicrograph of........... 100

Pyroxenite phase, of porphyritic gabbro, petrographic character of....... 98-101

\section{Q.}

Quartz, general features of veins of . ......... granulation and weld fractures of grain of, figure showing................. impregnating alaskite, photomicrograph showing ..................... in oligoclase granite, petrographic character of .......................... milky, photomicrograph showing........ 
Quartz, occurrence of, in quartz-hornblende gabbro

of Lantern Hill region, character and distribution of.

of Rhode Island, occurrence of. 136-146

primary, in quartz-hornblende gabbro, photomicrograph of .............

secondary, filling hornblende, photom!crograph showing .............. 104

undulatory extinction in, figure showing. $\quad 122$ Quartz-anorthosite, in quartz-bornblende gabbro, occurrence of . . ......... 108-109

Quartz-biotite schist, character and distribution of. .................... 17-18

intrusion of, in Lantern Fill quartz mass..................... 144-145

petrographic character of ............. $59-60$

Quartz-calcite veinlets, occurrence of, in porphyritic gabbro...............

Quartz-hornblende gabbro, petrographic character of.

photomicrograph showing. 102-111

to oligoclase granite......... 111

to porphyritic gabbro............ 108

Quartz hornblendite in quartz-hornblende gabbro, occurrence of ......... 108-109

Quartzite, character and distribution of. .... 16-17 petrographic character of

$\mathrm{R}$.

Regional metamorphism, of Preston gabbro, account of ................... 38-39

of Sterling granite gneiss, account of. .... 43-44 relation of Sterling granite gneiss to.... 127-131

\section{$\mathrm{S}$.}

Saussuritized gabbro, photomicrograph of... Schist, effect of compression on, figure showing...

fold in, at North Stonington, figure showing.

hornblendic, character of.... 18-20, 62-63, 66-67 in fold of lime-silicate rock, figure showing.

undulations in, figure showing..........

See also Kinzigite.

Schistosity, agreement of, with stratification. 24-25

Secondary brown hornblende, development of, in olivine gabbro and pyroxenite, photomicrographs showing....................... 100

occurrence of, in porphyritic gabbro. $80-84,101$

Secondary green hornblende, in quartz-hornblende gabbro, photomicrograph of.
Sedimentary rocks, character, classification, and distribution of............ 16-21

correlation of . ................... 146-148

metamorphic, petrographic features of... 58-78 Shear planes, observations of, map showing..................... In pocket.

Steiger, George, work of................. 9 Sterling granite gneiss, age and conditions of

intrusion of ............... 131-133

batholith, probable extent of . ........ 133-135

character and distribution of.......... 23-24

intrusive areas of .................... $35-38$

method of intrusion of .................. 38

relation of, to regional metamorphism.. 127-131

to Westerly granite................ 135

types, analyses, and petrographic character of .................... 119-135

Stonington quadrangle, Conn., parts of, topographic, geologic, and outcrop maps of.................. In pocket.

Stratigraphy, correlation problems in respect to..................... 146-149

Stream courses, relation of joints to........ 48-96 Strike and dip, observations of, map showing.................... In pocket. Strike lines, plate showing............. In pocket. Structural geology, account of............. 24-54 summary of ...................... 149-151 Swantown Hill, quartz deposit on........ 146

\section{T.}

Titanite, in amphibole sheets, occurrence of. . 113 in oligoclase granite, occurrence of....... 110 Topography, general features of........... 12-14 map showing.................... In pocket.

\section{U.}

Undulations, character and extent of...... 25-26 in schist, figure showing................ 25 Uralite, development of, in pyroxenite, photomicrograph showing........... 100

\section{V.}

Valleys, classification of................... 12-13

relation of joints to .................. 48-50

Veins, general features of................ $53-54$

W.

Westerly granite, relation of, to Sterling granite gneiss.

\section{$\mathrm{Z}$.}

104 Zircon, in oligoclase granite, occurrence of..... 